\author{
UNIVERSIDADE DE SÃO PAULO \\ ESCOLA DE COMUNICAÇÕES E ARTES
}

Maria Luiza Dias de Almeida Marques

\begin{abstract}
A transição do modo de produção analógico para o digital nas produtoras de animação publicitária: o impacto da tecnologia no cinema de animação
\end{abstract}



Maria Luiza Dias de Almeida Marques

\section{A transição do modo de produção analógico para o digital nas produtoras de animação publicitária: o impacto da tecnologia no cinema de animação}

Dissertação apresentada à Escola de Comunicações e Artes da Universidade de São Paulo para a obtenção do título de Mestre em Ciências da Comunicação pelo programa de Meios e Processos Audiovisuais

Área de Concentração: Estudos dos Meios e da Produção Mediática

Linha de pesquisa: Poéticas e Técnicas

Orientador: Prof. Dr. Eduardo Simões dos Santos Mendes

São Paulo 
Autorizo a reprodução e divulgação total ou parcial deste trabalho, por qualquer meio convencional ou eletrônico, para fins de estudo e pesquisa, desde que citada a fonte.

Marques, Maria Luiza Dias de Almeida Marques Dias de Almeida A transição do modo de produção analógico para o digital nas produtoras de animação publicitária: o impacto da tecnologia no cinema de animação / Maria Luiza Dias de Almeida Marques Dias de Almeida Marques. -- São Paulo: M. D. A. Marques, 2014 . 210 p.: il.

Dissertação (Mestrado) - Programa de Pós-Graduação em Meios e Processos Audiovisuais - Escola de Comunicações e Artes / Universidade de São Paulo.

Orientador: Eduardo Simões dos Santos Mendes Bibliografia

1. modelos de produção em animação 2. tecnologia digital 3. cinema de animação I. Mendes, Eduardo Simões dos Santos II. Título. 
Nome: MARQUES, Maria Luiza Dias de Almeida

Título: A transição do modo de produção analógico para o digital nas produtoras de animação publicitária: o impacto da tecnologia no cinema de animação

Dissertação apresentada à Escola de Comunicações e Artes da Universidade de São Paulo para a obtenção do título de Mestre Ciências da Comunicação pelo programa de Meios e Processos Audiovisuais

Aprovado em:

\section{Banca Examinadora}

Prof. Dr. : Instituição:

Julgamento: Assinatura:

Prof. Dr. : Instituição:

Julgamento: Assinatura:

Prof. Dr. : Instituição:

Julgamento: Assinatura: 

Ao meu companheiro Paulo de Tarso e aos meus filhos Estêvão e Tomás, com o maior amor do mundo.

Aos meus pais Fernando Paulo e Maria Cândida, com imensa gratidão. 



\section{Agradecimentos}

Todo o esforço empregado para descrever a ajuda que tive no desenvolver desta pesquisa será insuficiente para expressar a gratidão a todos que de forma direta ou indireta colaboraram comigo. Tenho consciência de que só consegui chegar ao final porque faço parte de uma teia firme de relações afetivas que me sustentou em todos os momentos, mesmo quando eu acreditava estar isolada.

A começar pela orientação zelosa do Prof. Dr. Eduardo Santos Mendes, que arriscou conduzir uma pesquisa fora de seu escopo e me adotou como aprendiz de pesquisadora, numa atitude de pura confiança e doação.

Aos entrevistados, que forneceram o substrato da pesquisa, proporcionaram encontros agradáveis em seus ambientes de trabalho e sempre se mostraram prontos para completar/confirmar informações essenciais.

Ao Fernando Fontaneti, que traduziu o resumo na camaradagem e ao Daniel Orey, que revisou a tradução.

À minha irmã Paula e ao meu cunhado Cláudio, pelo cuidado na impressão deste volume.

À minha família: meu Pai, Fernando Paulo e minha Mãe, Maria Cândida, que em momento algum questionaram ou reprimiram minhas escolhas, ao contrário, sempre se mostraram presentes e me apoiaram em todos os sentidos; e a meus irmãos, Maria Fernanda, Maria Paula e Fabiano, pelos bons conselhos.

À minha sogra, Maria do Carmo, que desde sempre me encorajou e dedicou seu tempo escasso a ler, sugerir, e me ajudar a melhorar o texto. Uma verdadeira fonte de conhecimento, referência e inspiração.

Aos meus filhos queridos, Tomás e Estêvão, que compreenderam e aceitaram a minha ausência em diversos passeios de família, e colaboraram quando precisei de silêncio. Sem saber, eles também são fonte de criatividade: muitas vezes, quando o texto travava, levantei-me para ficar com eles, apanhando-lhes opiniões, sacando como pensam.

Ao meu amado companheiro Paulo de Tarso, meu cúmplice, que propiciou que eu me dedicasse exclusivamente ao mestrado, provendo nossa família e assegurando um ambiente tranquilo para o meu estudo. É um privilégio inestimável estar a seu lado.

Ao meu círculo de amigas, irmãs de alma, com quem sei que posso contar sempre.

À Divina Providência, por eu ter conseguido fazer esta pesquisa sem deixar de fazer as coisas de que eu mais gosto, e em paz. 



\section{Resumo}

Este estudo tem como propósito pesquisar como as produtoras de animação publicitária em São Paulo absorveram gradativamente a tecnologia digital a partir de meados dos anos 1980 até os anos 1990, observando seu funcionamento antes, durante e após a implementação mais efetiva dos novos recursos, identificando os fatos e dados que apontam para o impacto no processo criativo em todas as suas etapas. A partir de uma revisão bibliográfica, apresenta-se o modelo de produção analógico em animação, permitindo-se conjecturar a respeito do ambiente sócio-cultural que propiciou o surgimento dos estúdios de animação que imprimiram sua marca na história da publicidade brasileira. Dentro de uma perspectiva de pesquisa qualitativa fundamentada na história oral, procura-se, por meio de entrevistas com os produtores, compreender o trajeto da realização de um filme de animação, tanto da era analógica como da era digital. Buscou-se, com a coleta de depoimentos, criar evidências para a pesquisa, esperando contribuir assim para o resgate histórico de um momento muito fértil em nossa animação, e de um segmento audiovisual tradicionalmente pouco contemplado nas discussões acadêmicas. Como resultado, obteve-se uma reflexão sobre a evolução do processo criativo, que se mostrou dar-se não apenas em função da tecnologia, mas também em função de um conjunto de elementos sócio-econômico-culturais que influenciam na fruição através dos tempos e determinam diretrizes de produtividade para o audiovisual.

Palavras-chave: cinema, cinema de animação, animação publicitária, meios digitais, transição digital. 



\begin{abstract}
This study aims to research how animation advertising companies have gradually absorbed digital technology in São Paulo from the mid-1980s until the 1990s. By observing their functioning before, during and after the effective implementation of new resources, and, by this investigative approach, the study identifies the facts and data which point toward the impact on the creative process at all its stages. In the review of literature, the analog production model of animation is presented, which allows for conjecturing as to what socialcultural environment has enabled the emergence of animation studios which have left their mark in the history of Brazilian advertising. From a qualitative research perspective grounded on Oral History, it used interviews with producers, to document and gain a clearer understanding of the making of an animation film, in both in the analog as well as in the digital era. By the collecting accounts, research evidence hopes to contribute to a historical review of a particularly fertile moment in the history of Brazilian animation. As well this study documents an audiovisual segment that traditionally is not addressed in academic discussions. As a result, a reflection of the development of the creative process was obtained, not only because of technology used but also by virtue of a set of social-economic-cultural elements which have influenced the fruition throughout times and determined productivity guidelines for the audiovisual.
\end{abstract}

Key words: cinema, animation film, animation advertising, digital media, digital transition. 



\section{Sumário}

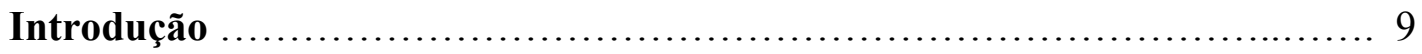

Capítulo 1 - A Evolução das Técnicas do Cinema de

Animação no Modo Analógico

Capítulo 2 - O desejo de animar e a articulação

das limitações na animação brasileira

Capítulo 3 - O Método de produção do cinema publicitário nos anos 70 e 80

Capítulo 4 - A chegada da nova ferramenta - o início da transição irreversível

Capítulo 5 - Gente nova no pedaço ..................................... 87

Considerações Finais ............................................ 103

Roteiro das entrevistas ........................................... 117

Apêndice A - Entrevista Joaquim Três Rios ................................ 119

Apêndice B - Entrevista Walbercy Ribas ............................. 131

Apêndice C - Enrtevista Daniel Messias................................... 151

Apêndice D - Entrevista Guto Carvalho.................................. 172

Apêndice E - Entrevista Alceu Baptista ................................. 183

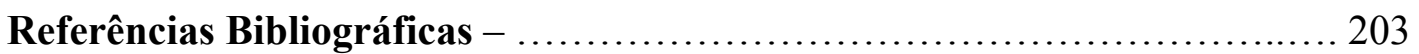




\section{Introdução}

Esta pesquisa busca elementos que permitam recuperar a memória do desenvolvimento da tecnologia digital na evolução do cinema de animação paulistano das décadas de 1980 e 1990, através da análise do impacto do uso da tecnologia digital, especialmente os computadores de escala pessoal ${ }^{1}$. Tal análise é estruturada nas informações obtidas em entrevistas com realizadores de animação publicitária que trabalharam nas décadas de 70,80 e 90 .

Voltando ao passado, à época em que fiz graduação, de 1991 a 1994, os trabalhos em table-top e com desenho animado pintado no acetato já apontavam ser um modelo de produção fadado a se extinguir, dada a morosidade dos processos e a falta de gente interessada naquele tipo de trabalho. Em um dos meus primeiros empregos, lembro-me do dia em que gastei cerca de 30 minutos fazendo um movimento combinado de zoom-out com travellig sobre uma fotografia, utilizando o software Director da Macromidia; naquele momento, atentei para o fato de haver recentemente feito trabalho semelhante no table-top da ECA, demorando para tal cerca de uma semana.

Motivada, portanto, pelo meu envolvimento profissional com a animação e tendo assistido a uma etapa adiantada do processo inserção dos computadores nas produtoras onde trabalhei, pude observar pessoalmente algumas mudanças no modo de se pensar o conjunto das ações envolvidas na produção de uma animação. Exceto pelo estúdio de Daniel Messias, com quem nunca tive contato antes desta pesquisa, de todos os outros entrevistados guardo alguma memória, a começar pela minha mesa de animação adquirida de Joaquim Três Rios na época em que ele desmontava seu estúdio. Na Start, de Walbercy Ribas, onde estagiei por um semestre, foi perceptível a reação crítica da equipe de animação tradicional ao Sillicon, que permanecia numa sala climatizada com acesso restrito. Lá, reclamava-se da falta de trabalho e de um futuro incerto, em que os computadores substituiriam por completo os animadores. $\mathrm{Na}$ Trattoria di Frame, fui assistente de Fernando Coster no filme Amassa que elas gostam e trabalhei em muitos comerciais em stop-motion. Na Vetor Zero, estagiei por pouco tempo, mas foi suficiente para entender que o trabalho deles está na linha de frente da computação gráfica.

\footnotetext{
${ }^{1}$ Esta pesquisa não trata dos computadores de grande porte, os mainframes.

${ }^{2} \mathrm{O}$ questionário encontra-se em Apêndice F.

${ }^{3}$ Chama-se repertório (também rolo, ou demo reel) o conjunto dos filmes mais expressivos realizados por um
} 
O conjunto dessas experiências tornou-se substrato para reflexões no momento em que fui convidada a dar aulas e oficinas de animação. A fundamentação teórica que acompanha a parte prática das aulas mostrou-se importante na medida em que revela aos alunos diferentes modos de se expressar em animação e aponta para o uso adequado de cada ferramenta. Portanto, compreender um pouco da história da animação e o contexto em que os computadores tomaram parte nela auxilia o desenvolvimento de discussões e alimenta o processo criativo.

Absorvido gradativamente por praticamente todos os setores produtivos da economia nas últimas décadas, o computador propicia rapidez, diminui distâncias e permite o controle mais acurado das tarefas, entre tantas outras atribuições, o que consequentemente alavanca a produtividade. Os estúdios de animação, empresas que lidam com um produto de realização complexa, também adotaram os recursos computacionais, atravessando um período de transição entre um modelo de produção analógico para o modelo de produção digital.

Este período particular é precisamente o foco desta pesquisa. Buscamos nas entrevistas aquilo que, em geral, não encontramos nas referências bibliográficas, ou seja, um passo a passo do processo de digitalização da estrutura produtiva, a observação do modo como o computador foi se integrando ao ambiente de trabalho até tornar-se inconcebível fazer animação sem utilizá-lo em alguma das etapas da produção. Foi indispensável, portanto, retroceder na história do cinema de animação mundial, para compreender como este cinema se estruturou como negócio no início do século XX, sobretudo nos EUA, beneficiando-se de melhorias tecnológicas e criando um sistema empresarial de organização. A observação deste contexto permitiu traçar um paralelo com o modelo de produção de animação que se viabilizou no Brasil.

Em meio à falta de recursos e de políticas de apoio, somente a paixão pelo ofício poderia justificar a dedicação de tantos animadores independentes a filmes que dificilmente chegariam às salas de exibição, quando muito a festivais e mostras esparsas. Assim, a animação destinada às telas de cinema no Brasil foi conquistando seu espaço junto a um pequeno público com frequência irregular, enquanto que a vertente publicitária encontrou nos comerciais de TV seu veículo expressivo prioritário, através dos quais o público pôde ter contato com animadores de primeira grandeza.

A opção, portanto, de pesquisar o universo dos estúdios de animação publicitário deuse por tratar-se de empresas que produziram milhares de filmes animados ao longo de três décadas, se contarmos apenas o período do modelo analógico, e que tinham suporte financeiro para investir em aprimoramento técnico com frequência regular. Dentro deste universo, a 
amostra considerada representativa constitui-se dos estúdios paulistanos que se destacaram tanto por sua participação no mercado, como pela capacidade de criar filmes antológicos para a publicidade. São eles: Joaquim Três Rios, Walbercy Ribas, Daniel Messias, Guto Carvalho e Alceu Baptista, que podem divididos em dois grupos: o grupo dos animadores da era analógica, Três Rios, Ribas e Messias, que iniciaram suas carreiras na década de 1960 e o grupo dos animadores digitais, Carvalho e Baptista, que iniciaram suas carreiras na década de 1980.

Como metodologia utilizei pesquisa qualitativa ancorada teoricamente no método da história oral (GARNICA, 2004, p. 77-98) captada através de entrevistas em profundidade, ou não estruturadas, que visam "obter do entrevistado o que ele considera os aspectos mais relevantes de determinado problema: suas descrições de uma situação em estudo", procurando saber como e por que algo ocorre. (RICHARDSON, 1999, p. 208).

Antes da elaboração de um roteiro de entrevistas, iniciei a coleta de dados históricos a partir da revisão de literatura que se mostrou carente de registros detalhados das obras brasileiras inaugurais. Um fato marcante é que na maior parte das vezes, os textos enfatizam a cronologia fílmica e a condição periférica da animação brasileira. Havendo poucas informações a respeito de diferentes contextos de produção, esta bibliografia limitada, de certo modo, estimulou a formulação de questionamentos e ajudou a amadurecer o objeto desta pesquisa, dado que as lacunas nas informações acerca do fazer propriamente dito, em animação, acenderam pontos de dúvida, os quais foram organizados conceitualmente e colocados aos entrevistados através dos questionários. Apoiando-nos em um quadro teórico mais abrangente - em que, para além do cinema de animação brasileiro, observamos os desafios do nosso cinema como um todo, o início e a evolução da animação mundial, aspectos da percepção humana e as estruturas de produção nos estúdios de animação - foi possível determinar quais índices mereceram ser contemplados na busca pelo traçado do panorama aqui proposto, o de compreender a transição entre dois modelos de produção, a saber: a estrutura das empresas, o fluxo de trabalho e o aspecto visual dos filmes.

Deste modo, no período da revisão de literatura foi criado um questionário de perguntas abertas $^{2}$, dividido em blocos de questões. $\mathrm{O}$ primeiro foi aplicado a todos os entrevistados e tratou dos seguintes temas: 1) a formação do animador e suas influências artísticas; 2) como estruturou seu estúdio em termos de equipe e equipamentos; 3) orçamentos; e 4) distribuição das tarefas. O segundo conjunto de questões foi aplicado apenas

\footnotetext{
${ }^{2}$ O questionário encontra-se em Apêndice F.
} 
ao grupo dos animadores da era analógica que se adaptaram à produção digital e abrangeu os temas: 1) a aquisição dos primeiros computadores; e 2) quais mudanças ocorreram no funcionamento da empresa. O terceiro bloco, dirigido apenas ao grupo de animadores da era digital, foi sendo construído a partir das respostas que obtive das questões que versam sobre a formação e o início do estúdio. Todas questões, entretanto, consistiram em um "guia de temas a ser explorados durante a entrevista" (RICHARDSON, 1999, p. 210), possibilitando bastante liberdade por parte dos entrevistados.

Realizadas as entrevistas e suas transcrições, foi feito um fichamento de acordo com os blocos temáticos do questionário, a partir do qual pude desenvolver o texto, buscando relacionar as respostas dos entrevistados à investigação de pesquisa, seguindo de um modo geral a cronologia dos fatos e conectando acontecimentos afins em um estúdio e em outra, ora comparando-os, ora relacionando-os com o momento sociocultural em que se davam.

A coleta das informações diretamente com animadores/produtores envolvidos com a animação publicitária trouxe visões que ora se complementam, ora se sobrepõem, ora se contradizem, e que invariavelmente transpiram frescor e autenticidade, revelando a cada passagem relatada, a cada hesitação ou mudança na entonação vocal, uma verdadeira contribuição para a pesquisa em animação. Percebe-se, além dos limites da memória, onde a riqueza de detalhes não é sempre vívida, a atmosfera de um tempo, sobretudo naquilo que é dito nas entrelinhas, ou ainda, não mencionado diretamente, mas que se deixa escapar.

A acuidade na tomada das informações pelo método da história oral garantir-se-ia através da leitura e confirmação, por parte dos entrevistados, da transcrição das entrevistas, o que não ocorreu em nenhum dos casos, visto que não obtive o retorno após algumas solicitações via e-mail. Este foi, junto com a escassez de fontes de pesquisa, um inconveniente, que aparentemente não prejudicou o andamento do trabalho, mas que forneceria bons ajustes caso a leitura das transcrições despertasse nos entrevistados a memória de algo que não foi dito na entrevista presencial ou a correção de algum mal-entendido. Por outro lado, sempre que solicitei por e-mail informações pontuais (datas, links para filmes, por exemplo), obtive prontamente as respostas.

De 2012 a 2013 realizei, pois, entrevistas presenciais com Joaquim Três Rios, Walbercy Ribas, Daniel Messias, Guto Carvalho e Alceu Batista, as quais encontram-se transcritas nos apêndices A, B, C, D, e E deste volume. No mesmo período, realizei um levantamento de animadores tradicionais freelancers que trabalharam nesses e em outros estúdios no período em questão, para saber se de alguma forma presenciaram a transição do sistema analógico para o digital. Estes forneceram detalhes complementares e informações 
sobre o dia a dia do trabalho pela óptica dos funcionários e nos permitiram imaginar como foi a entrada dos computadores nos estúdios de animação. São eles Márcia Alevi, Gil Caserta e Arnaldo Galvão, que sempre se mostraram dispostos e interessados em colaborar.

A primeira das entrevistas foi com Joaquim Três Rios, em agosto de 2012. Homem sem cerimônias, mostrou-se disponível desde o primeiro contato; recebeu-me em seu pequeno apartamento numa vila do Bairro da Aclimação, onde vive com sua esposa Terezinha. Com seus 80 anos, aposentado, ele realiza oficinas e palestras sobre animação em várias cidades do interior, em parceria com o animador Gil Caserta, responsável pela digitalização de parte do repertório ${ }^{3}$ de Joaquim. As latas de negativos de alguns filmes, dentre eles um teste de animação que fez - por conta própria - para a abertura da novela Tieta (rede Globo, 1990) foram arquivadas na própria casa de Joaquim e seus equipamentos estão armazenados na Cinemateca; vários de seus filmes telecinados estão disponíveis no site Vimeo ${ }^{4}$.

A importância de Joaquim Três Rios para a animação no Brasil é imensa. Além de filmes comerciais memoráveis, como Cobertores Parahyba e das aberturas de programas que permaneceram muitos anos no ar, dentre os quais Os Trapalhões, Jornal Nacional e Fantástico, pode-se dizer que a evolução do design gráfico animado para TV passou pelas mãos de Três Rios.

A segunda entrevista foi com Walbercy Ribas, da Start, e aconteceu em agosto de 2013, em seu estúdio, na Vila Mariana. Em meio a muitos quadros e pôsteres de filmes premiados, Walbercy tem consciência do que ele representa para a animação brasileira e, sem falsa modéstia, desfiou suas glorias e dificuldades, deixando transparecer uma visão nostálgica em relação a um tempo em que a publicidade tinha mais vigor. À semana de minha visita, Walbercy havia queimado literalmente milhares de desenhos em papel e acetato, em meio a uma reforma na grande edícula onde funcionou outrora o departamento de pintura da Start. Com apenas dois funcionários na computação gráfica, ele estava envolvido em uma animação em 3D para a Copa do Mundo. Conhecedor profundo da animação do Leste Europeu, Walbercy foi um dos que mais imprimiu sua marca pessoal nos filmes que dirigiu, obtendo até mesmo carta branca do cliente para criar as imagens mais surreais, como acontecia nos filmes da série Sharp.

A terceira entrevista aconteceu em setembro de 2013, com Guto Carvalho, que me recebeu em sua casa. Após compreender o objeto da pesquisa, Guto discorreu com fluidez e

\footnotetext{
${ }^{3}$ Chama-se repertório (também rolo, ou demo reel) o conjunto dos filmes mais expressivos realizados por um profissional de audiovisual, costumeiramente dipostos em sequência numa mesma mídia.

${ }^{4}<$ https://vimeo.com/channels/joaquim3rios> Acessado em: 21/01/2012.
} 
com boas reflexões, num depoimento que contribuiu particularmente na elaboração das considerações finais. De todos os entrevistados, ele é o único não-animador, tendo utilizado a animação em suas pesquisas sobre o movimento, já iniciadas na época em que estudou física e dança.

Na sequência, em outubro de 2013, entrevistei Daniel Messias, em seu estúdio no Pacaembu, uma grande casa comprada em 1975, quando o estúdio saiu do bairro de Santana. A casa vizinha, igualmente grande, pertenceu no passado ao estúdio, na época em que se faziam três a quatro filmes por mês. Daniel não mostrou cerimônia ao falar de dinheiro, da relação estressada com as agências e, enfim, das dificuldades cotidianas, informações surpreendentes, já que seus sofisticados filmes não denunciam os orçamentos estreitos. Daniel Messias, junto com Walbercy Ribas, formava o primeiro escalão da animação publicitária brasileira nos anos 80 e seu estúdio, além de produções originais, como o frango da Sadia, produzia com exclusividade filmes com a turma do Snoopy, do Pernalonga, entre outros.

A última entrevista foi com Alceu Baptista, sócio-fundador da Vetor Zero, também em outubro de 2013. Esta entrevista beneficiou-se por ter sido a última, aquela em que consegui cercar alguns temas e verificar informações dos demais entrevistados. Sempre acessível, Alceu encontrou uma brecha em sua rotina atribulada para me conceder durante $1 \mathrm{~h} 20$ minutos muitas das peças que faltavam no quebra-cabeças, fornecendo uma visão detalhada de toda uma linhagem de equipamentos que foram surgindo, além de esclarecer como o 3D conquistou o mercado. Com forte atuação no ramo de efeitos e composição com cenas ao vivo, a Vetor Zero é referência internacional em animação 3D, contando com diferentes parcerias na criação de trabalhos inovadores.

O resultado da pesquisa foi um texto dividido em dois grandes blocos: o primeiro, tecido a partir da bibliografia, traz a recapitulação histórica em função dos avanços técnicos. Este primeiro bloco cobre o período de 1907 até meados dos anos 1960 e é formado pelos Capítulos 1 e 2. O segundo, talhado sobre as entrevistas, é composto pelos Capítulos 3, 4 e 5 que trazem informações inéditas a respeito do funcionamento dos estúdios, desde a sua montagem até seu processo de digitalização.

Assim, o conteúdo de cada capítulo apresenta-se organizado da seguinte maneira:

\section{Capítulo 1 - A evolução das técnicas do cinema de animação no modo analógico}

Neste capítulo, expõem-se os mais importantes avanços na área técnica da animação e seus responsáveis. Observar-se-á como esses avanços se agregam, como se dão seus reflexos na linguagem e como eles propiciam o aparecimento da indústria da animação moderna. 


\section{Capítulo 2 - $O$ desejo de animar e as limitações de recursos na animação brasileira}

Este capítulo traz uma breve exposição acerca da animação no Brasil e os desafios permanentes impostos à produção. Buscou-se compreender os caminhos traçados pelos animadores quando da criação das produtoras de animação nos anos 1960.

\section{Capítulo 3 - O método de produção do cinema publicitário nos anos 70 e 80}

Neste capítulo, a partir das entrevistas de Joaquim Três Rios, Daniel Messias e de Walbercy Ribas, analisei como se formatou o modelo analógico de produção e suas especificidades.

\section{Capítulo 4 - A chegada da nova ferramenta - o início da transição irreversível}

Os primeiros computadores entram em cena. Veremos a sucessão de computadores e softwares adquiridos pelos estúdios estabelecidos no mercado e como a configuração da estrutura empresarial foi se modificando.

\section{Capítulo 5 - Gente nova no pedaço}

Uma nova geração identifica na tecnologia o meio para materializar uma expressão multifacetada em animação. A partir das entrevistas com Guto Carvalho e Alceu Baptista reconstutui-se a entrada de empresas baseadas em tecnologia digital no mercado.

O esforço aqui empreendido pareceu-nos urgente ao nos deparar com o fato de que vários dos nossos grandes animadores encontram-se em idade avançada e suas histórias pessoais revelam informações preciosas de um período particularmente rico em nossa produção publicitária. Aproveitar estas fontes primárias de informação foi uma oportunidade singular de colaborar com a preservação da memória da animação no Brasil. Descortinamos, assim, um pouco do cotidiano dos estúdios, da relação com as agências de publicidade e com o momento sociocultural e econômico vivido, para saber em que medida os meios digitais reconfiguram a ordem instituída. Optamos por nos concentrar em aspectos diretamente ligados à produção a enfatizar aspectos estéticos, que julgamos servir de tema para uma outra pesquisa. 


\section{Capítulo 1 - A evolução das técnicas do cinema de animação no modo analógico}

Pesquisar o cinema de animação significa deparar-se com um número notável de textos que se iniciam pelas evidências do desejo humano de representar o movimento encontradas nas paredes das cavernas. Considera-se bem contado o histórico das imagens em movimento e bem documentadas as invenções ópticas em inúmeros estudos que tratam do advento do cinema. Há também boas fontes de estudo que trazem a evolução do cinema de animação, desde as experiências de Georges Méliès - executando a substituição por parada de ação $^{5}$ - com seus filmes de efeitos, até a eclosão do fenômeno Mickey Mouse e a consolidação do cinema de animação como entretenimento de massas.

Por conta disto, deixaremos de lado a cronologia técnica que antecede o desenvolvimento da câmera de cinema com disparador de um quadro por vez, em 1905 (CHONG, 2011, p. 21) para nos atermos ao desenvolvimento de dispositivos que determinaram os caminhos do cinema de animação ao longo do século XX.

Dentre os autores que se debruçaram sobre o tema de maneira investigativa, realizando entrevistas, analisando e comparando documentos e filmes, Donald Crafton ${ }^{6}$ mostra-se como um dos mais relevantes. Ele nos trás informações a respeito de técnicas e as relaciona com o espírito de cada época estudada, considerando que os primeiros 25 anos do cinema concentraram a construção de todo um arcabouço de linguagem cinematográfica. Sua constatação de que

[...] as estruturas formais dos filmes refletiam muitas fontes de influências, incluindo tecnologias, pressões comerciais (distribuidores, público, a concorrência), tradições em outras artes populares, as personalidades dos animadores, e 'hábitos narrativos' (fórmulas de contar histórias em filmes curtos) (CRAFTON, 1993, p. xviii) (tradução nossa)

dá a dimensão da intrincada rede das variáveis que determinaram os caminhos do cinema de animação e auxilia na compreensão desse fenômeno que agrega arte, ciência e negócios.

Em sua obra Before Mickey - The Animated Film, Crafton realiza uma minuciosa pesquisa, em que verifica que o método de produção de desenhos animados cristalizado pelos irmãos Fleisher e por Walt Disney a partir da década de 1920 tem sua origem na estrutura de trabalho organizada pelo desenhista e empresário John Randolph Bray, que se baseou em

\footnotetext{
${ }^{5}$ Denomina-se "substituição por parada de ação' o processo pelo qual o cineasta interrompe o funcionamento da câmera de filmar, substitui algum elemento de cena e reinicia a filmagem em seguida, obtendo como resultado uma transformação inusitada, por exemplo uma cadeira onde aparece um homem sentado.

${ }^{6}$ CRAFTON, Donald. Before Mickey: the Animated Film 1989-1928. Chicago: The University of Chicago Press, 1993.
} 
teorias da administração clássica para organizar o trabalho no estúdio. Ainda que comercializassem e distribuíssem seus filmes, animadores como o francês Emile Cohl e o americano Winsor McCay, concebiam e trabalhavam de maneira artesanal (CRAFTON, 1993, p. 137).

Isto não significa que estes e outros artistas pioneiros na animação não tenham perseguido métodos para agilizar o árduo trabalho de se fazer tantos desenhos por segundo, pois, como menciona Crafton (1993, p. 137): "na otimista atmosfera pré-Primeira-Guerra [...] parecia haver uma solução tecnológica para praticamente todos os problemas [...]”.

A seguir, relacionaremos as principais invenções, descobertas e sistematizações atribuídas aos animadores pioneiros, que tiveram o intuito de viabilizar e aperfeiçoar os métodos de produção na animação, a partir das quais pode-se erguer a animação industrial moderna. Tais contribuições, decisivas, agiram sobre os campos técnico, artístico e administrativo, a saber: a caixa de luz, os pinos de referência, a fotografia duplicada de cada imagem, o acetato, o rotoscópio e a divisão de trabalho. Estamos nos referindo ao período que vai de 1910 a 1915 e aos métodos de produção em vigor até o final dos anos de 1980, quando, na esteira dessas invenções, encontraremos os computadores gráficos.

\section{Desenvolvimento e padronização do desenho animado}

Aos artistas a seguir atribui-se inovações técnicas ou procedurais que forjaram o sistema dos estúdios de animação. No curto período que vai de 1910 a 1915, a completa tecnologia foi desenvolvida, florescendo e se padronizando. Tal evolução técnica conjugou-se com um momento histórico em que a estrutura do pensamento capitalista convertia-se em práticas administrativas. Os mesmos aspectos históricos que contribuíram para a hegemonia do cinema norte-americano levaram a animação a estabelecer-se como indústria do entretenimento de massas. Vale pensar que, ao tempo dessas descobertas, todas as possibilidades do cinema estavam por se descortinar, diferentemente da época em que os computadores entraram na produção de animações, quando o cinema já havia passado por crises e a narrativa cinematográfica carecia de renovação.

Emile Cohl - a caixa de luz

A concepção popularizada do cinema de animação como um filme feito de 24 desenhos por segundo esconde a complexa estrutura de produção de um filme de animação. 
Há muitas nuances em técnicas, frutos de exaustivas experiências ao longo dos 20 primeiros anos do cinema, cujo objetivo era tornar a capacidade produtiva condizente com a demanda do público. Iniciaremos com Emile Cohl e Winsor McCay, cujas contribuições técnicas ampliaram as possibilidades artísticas e definiram duas correntes expressivas do início da animação, especificamente do desenho animado.

Emile Cohl, que considerava-se a si mesmo o fundador da animação e morreu desconhecido com uma produção de mais de 250 filmes (CRAFTON, 1993, p. 59), conheceu o cinema com 51 anos. Ele trouxe sua bagagem cultural formada nas artes plásticas, nos quadrinhos e na ilustração populares, para as experiências em animação, quando descobriu que alguns filmes da Gaumont baseavam-se em suas tiras de quadrinhos. "Ao se dirigir ao estúdio para exigir seus direitos, foi surpreendido pela proposta de adaptar suas histórias para o cinema (JÚNIOR, 2005, p. 50).

Aspectos artísticos e técnicos reconhecidos fizeram de Cohl o fundador do cartoon moderno (CRAFTON, 1993, p. 60). Dentre os artistas, sua original visão de mundo, "antirracional", suas associações de ideias e seu humor sarcástico transcreviam-se em metamorfoses sugestivas e na exploração do campo fílmico para a representação de profundidade, alguns dos elementos que compõem a gramática visual desenvolvida por Cohl. Suas ilustrações para a imprensa apresentavam complexidade nos traços (fig.1) e concisão conceitual. Deparando-se com a tarefa de produzir diversos filmes, Cohl se propõe a simplificar o traço (fig. 2), sem deixar de lado a expressividade, explorando as possibilidades da linha (JÚNIOR, 2005, p. 50).

Efetivamente, dentre os aspectos técnicos o uso da caixa de luz foi um grande avanço que permitiu visualizar os desenhos anteriores e, assim, produzir os desenhos subsequentes permitindo mais controle da forma e do espaço entre os desenhos. Esse artefato refletiu-se num salto qualitativo na estabilidade das imagens, além de agilizar a produção dos desenhos. A partir de sua experiência prática, Cohl percebeu que poderia fotografar duas vezes cada desenho sem que houvesse perda significativa na fluidez dos movimentos, o que reduziu pela metade o esforço empenhado nas produções (CRAFTON, 1993, p. 61-74); esta foi outra contribuição vital para a animação, dada a pressão pela produção em série. Outra experiência bem sucedida de Cohl foi a combinação de imagens live-action com animação, nos filmes em que sua mão aparece desenhando e, ao sair do quadro, o desenho inicia o movimento, o que acontece em Fantasmagorie, de 1908. Cohl também foi o primeiro a abandonar a câmera de manivela pela câmera elétrica, em 1909, o que facilitou o trabalho e permitiu a exposição 
mais precisa de cada frame, eliminando a "flicagem" sempre presente nos primeiros filmes animados.

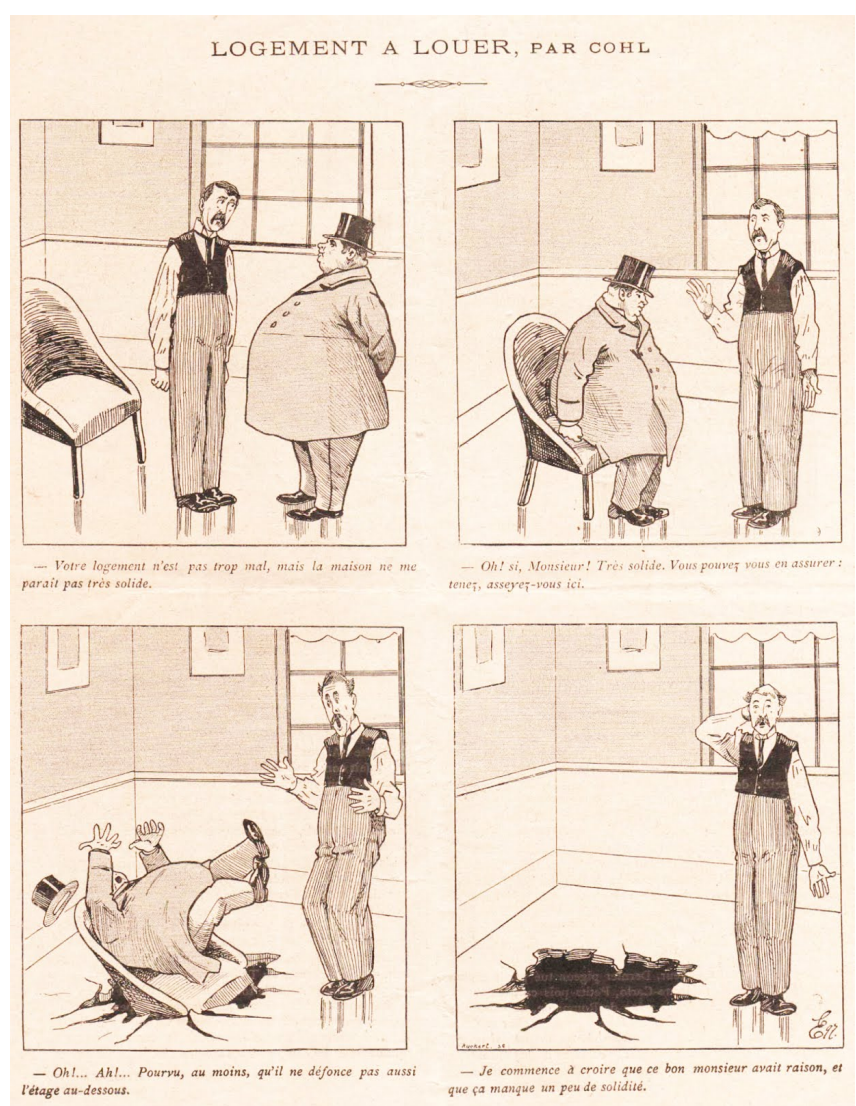

Figura 1- Página de quadrinhos da revista Polichinelle' 9.Mai $1897^{7}$

"- Seu apartamento é bom, mas a construção não me parece muito sólida.

- Oh, sim, Senhor, Muito sólida, assegure-se disso; tome, sente-se.

- Que pelo menos não ceda o andar de baixo.

- Começo a crer que este bom homem tinha razão e que falta um pouco de solidez."(tradução nossa)

Assim, o reconhecimento a Emile Cohl deve-se sobretudo à sua conquista em dissociar a animação dos filmes de efeito, demonstrando a afinidade potencial entre animação e arte popular, de um lado e, de outro, desenvolvendo a tecnologia que permitiu com que o cinema de animação fosse viável comercialmente (CRAFTON, 1993, p. 86).

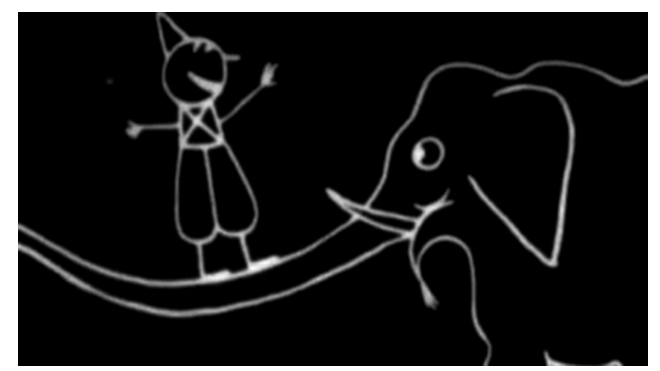

Figura 2 - fotograma de Fantasmagorie, de 1908

Comparado à imagem superior, observa-se a economia no traço.

\footnotetext{
${ }^{7}$ Extraído do site http://konkykru.com, (acessado em 04-05-2013).
} 


\section{$\underline{\text { Winsor McCay - pinos de registro }}$}

Nos Estados Unidos, um artista de outra corrente expressiva, contrastante com Emile Cohl na animação de desenhos, foi Winsor McCay. Igualmente oriundo da ilustração para imprensa, os desenhos de McCay são sofisticados e seus quadrinhos já contém o gérmen da decupagem espacial. Enquanto que Cohl abandonou seu estilo gráfico e escolheu a linha simplificada para produzir seus filmes, McCay não economizou esforços para trazer aos desenhos animados toda a complexidade de seu trabalho no jornal (CRAFTON, 1993, p. 89).

Desta forma, em Little Nemo in Slumberland, McCay cria um enredo abstrato, no qual explora metamorfoses e movimentos à exaustão, demonstrando seu conhecimento de perspectiva nas cenas em que os personagens movem-se no espaço tridimensionalmente. A ele atribui-se a criação do primeiro personagem animal com características psicológicas e de comportamento humanizado, Steve, o mosquito de The Story of a Mosquito, de 1912. Neste filme, Steve usa chapéu e carrega uma valise de trabalho onde guarda o esmeril para afiar o bico antes de sugar o sangue do homem que dorme. A empatia com o público se dá de forma calorosa com Gertie, The Dinosaur, de 1914, um filme-espetáculo em que o autor do filme, no palco do teatro, contracena com o dinossauro projetado na tela.

McCay utilizava papel de arroz para obter a transparência e desenvolveu o sistema de pinos na mesa de animação (fig.3), com as folhas perfuradas, para garantir a referência fixa nas imagens. $\mathrm{O}$ animador não se preocupou em patentear este invento, o que foi feito mais tarde por John Randolph Bray.

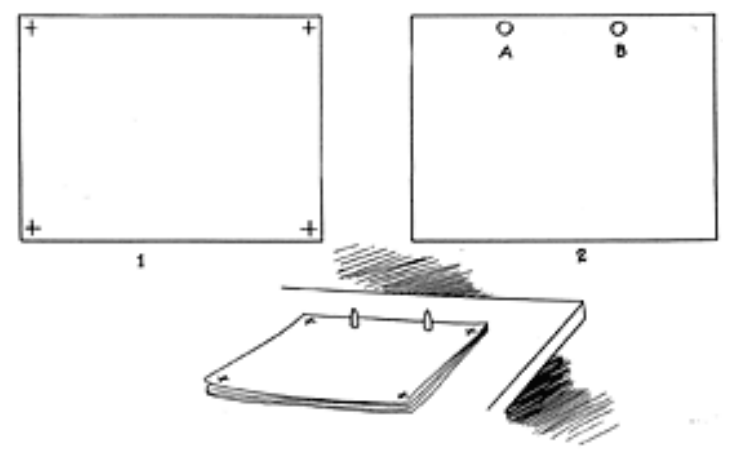

Figura 3 - detalhamento do sistema de pinos feito por McCay.

Em seus três primeiros filmes, McCay não utilizou o acetato como um recurso para descolar o personagem do cenário. Em Little Nemo in Slumberland não há cenários, já em The Story of a Mosquito e em Gertie-The Dinosaur, os cenários são todos retraçados em todas as 
folhas de desenho por assistentes de McCay, ficando em sua função a complexa animação do personagem Gertie.

Posteriormente, em The Sinking of Lusitania, lançado em 1918, McCay buscou um tom documental ao estilo dos cine documentários da época, retratando o naufrágio do navio de passageiros da Lusitania. Os movimentos das ondas, o deslocamento do navio e, ao final, pessoas pulando no mar e o navio afundando são cenas de um realismo jamais obtido em desenho animado, o que foi possível com o uso de acetatos - pela primeira vez, McCay os utiliza - para se poder trabalhar em diferentes níveis de profundidade. Para os cerca de 25.000 desenhos, o animador trabalhou com uma equipe de 6 assistentes.

O grafismo de McCay estabeleceu um padrão para os animadores vindouros. [...] Sua influência é visível nos primeiros anos da era dos estúdios de animação, na predileção por linhas pretas em fundo branco. [...] e virtualmente definiu as regras estéticas da animação na América, à parte do trabalho feito na Europa. (CRAFTON, 1993, p. 134-135) (tradução nossa)

O legado de Winsor McCay é, portanto, indiscutível para o desenho animado das gerações seguintes, seja pelas técnicas empregadas, seja pelo estilo gráfico ou pela noção da representação de movimentos nunca antes vistos por olhos humanos, como por exemplo a caminhada de um dinossauro em Gertie. Para alguns pesquisadores, a caracterização humana dada aos animais é considerada a sua mais valiosa contribuição, dada a influência que veio a marcar gerações dos filmes que empregam desenhos de animais em seu elenco.

\section{John Randolph Bray - o acetato e a visão administrativa}

O empresário John Randolph Bray inseriu no negócio da animação inovações em termos de gestão de pessoas, que transformaram de modo irreversível o métier. Suas interferências ocorrem no âmbito administrativo e no registro de patentes. Até mesmo invenções que não eram suas ou de seus empregados, foram reivindicadas pelo Bray Studios Inc. Se, por um lado, McCay foi para Walt Disney uma inspiração artística, Bray forneceu o modelo empresarial.

Assim como Cohl e McCay, Bray inicia sua carreira na imprensa, com uma página de história ilustrada, Little Johnny and the Teddy Bears, em 1907. Assim como McCay, suas ilustrações são meticulosas e ricas em pormenores. Sua primeira tentativa de produzir um desenho animado, em 1910, foi levar seus personagens para a tela. Em algumas semanas, entretanto, percebeu que tal empreendimento resultaria inviável comercialmente se ele não encontrasse maneiras de eliminar esforços na confecção dos desenhos. Meses mais tarde, 
lançou The Artist's Dream, com cenas ao vivo intercaladas com cenas animadas. Charles Pathé, o distribuidor francês, entusiasmou-se com este filme e encomendou seis filmes em seis meses. Para dar conta desta demanda, Bray concentrou-se em traçar uma estratégia de trabalho seguindo três diretrizes: 1) dividir as tarefas, distribuindo-as entre animadores e assistentes; 2) patentear este sistema de produção, bem como todos os métodos conhecidos até então, incluindo equipamentos ${ }^{8}$; 3 ) melhoria dos meios de distribuição e marketing dos filmes (CRAFTON, 1993, p. 145).

Antes do desenvolvimento do acetato - folha transparente para onde os personagens já desenhados eram retraçados - a tarefa de retraçar os cenários onde se davam as histórias era um dos entraves para que a atividade de animação tivesse viabilidade comercial. Além de ser um processo trabalhoso, as pequenas variações entre um e outro desenho têm suas dimensões ampliadas quando projetado o filme na tela. Para contornar este problema, Bray passou a imprimir os cenários em todas as folhas de animação, deixando uma região em branco para a inserção da figura do personagem (processo devidamente patenteado).

Foi, então, em 1914 que seu sócio-funcionário Earl Hurd patenteou um invento com a precisa descrição do acetato (celuloide ou nitrato de celulose). Esteticamente, "o acetato descortinou um novo mundo visual” (CRAFTON, 1993, p. 150), permitindo, na época, a justaposição de até três camadas de imagem, sendo que apenas as partes que se moviam necessitavam ser desenhadas. Os cenários poderiam, agora, ter um tratamento mais detalhado, com possibilidade de movimentação das personagens em um cenário fixo (fig. 4).

Já em relação ao modelo de gestão empresarial adotado, Bray adere à teoria Taylorista $^{9}$, que se apresentava como uma solução para se obter o máximo de desenhos, em rápida execução, com um mínimo de esforço e despesa. O princípio básico era a divisão entre gerenciamento e trabalho, entre a função do chefe e a dos empregados. A divisão das tarefas entre a equipe de desenho também passou a seguir uma hierarquia em que o artista sênior executava os desenhos que se moviam e os assistentes faziam as partes estáticas dos personagens. Com o passar dos anos, esta estratificação das funções sofreu adaptações e novas tarefas foram integradas, como o diretor de arte, o diretor de animação, o intervalador, o clean up, o filetista. Conforme o tamanho da produção, mais funções são incorporadas.

\footnotetext{
${ }^{8}$ Quanto ao registro de patentes, Bray reclamou para si a invenção da mesa de pinos de registro de McCay, da mesa de luz e até mesmo o processo de se "flipar" os desenhos para conferir a fluidez do movimento. Com as patentes, Bray pretendia obter o monopólio do processo; outros animadores, como Cohl e Blackton cogitaram patentear seus inventos, mas consideravam-no impraticável.

${ }^{9}$ Referência à teoria administrativa pioneira de Frederick W. Taylor, datada de 1880, que preconizava, entre outros, a linha de montagem na produção.
} 


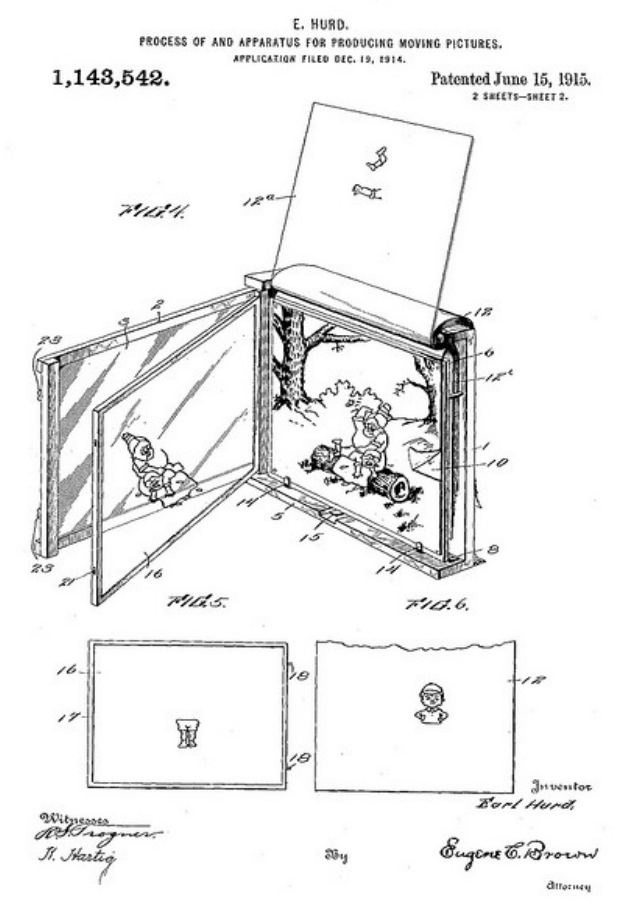

Figura 4 - Desenho da patente do acetato de Earl Hurd, em 15 de junho de 1915.

Outras lições do taylorismo referem-se à: 1) forma de pagamento: um salário base a todos os empregados, um bônus para trabalho executado no prazo e um bônus-extra, no caso de trabalho finalizado antes do prazo; e 2) supressão da individualidade: todos os artistas deveriam desenhar segundo o mesmo estilo (CRAFTON, 1993, p. 164).

A busca pela eficácia e rapidez, enfim, levou naturalmente ao desenvolvimento de gêneros e fórmulas. Criavam-se bancos de cenas, as quais eram reutilizadas em vários filmes, com poucas alterações, o que dava ao cinema de animação mais chances de competir com o cinema "ao vivo".

\section{Max \& Dave Fleischer o rotoscópio e a intervalação}

Para completar a lista das inovações técnicas que permitiram aos animadores multiplicar suas possibilidades expressivas e estudar com acuidade os movimentos, surge o rotoscópio (fig. 5), criação de Dave Fleischer, em 1915.

Este equipamento consistia num projetor de película apontado para uma tela translúcida onde se formava a imagem previamente filmada e onde o desenhista colocava sua folha de papel; tendo a imagem projetada como referência, ele poderia aplicar o seu traço conforme o planejamento da cena. Ao proporcionar imagens de movimentos reais, o animador 
teria facilidade em colocar seu personagem em determinadas perspectivas e em controlar o tempo de cada ação. Os dois irmãos, Max e Dave Fleischer, usaram seu invento para entrar na empresa de Jonh Randolph Bray, onde passaram a produzir a série Out of the Inkwell e também em filmes que mesclavam cenários/personagens reais com desenhos animados. Max e Dave Fleischer eram conscientes do risco que a cópia fiel do movimento poderia trazer ao desenho animado (JÚNIOR, 2005, p.71). O animador deveria, pois, usar o referencial como guia e não como cópia, podendo realizar exageros ou simplificações nas formas e no ritmo da ação.

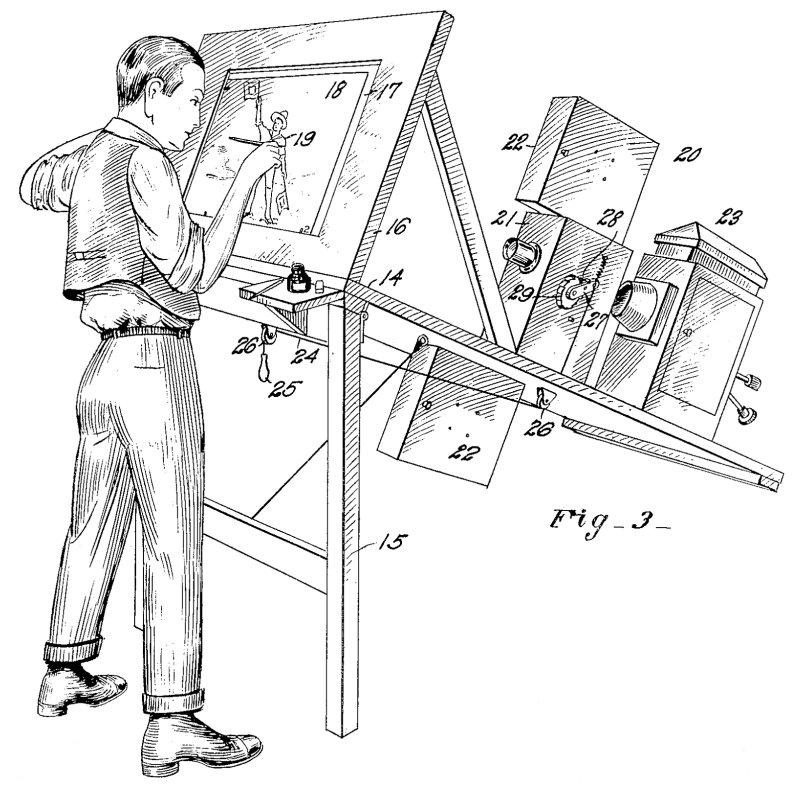

Figura 5 - desenho do rotoscópio de Dave Fleischer apresentado no documento da patente.

A série Out of the Inkwell, lançada em 1920, trazia o palhaço KoKo (fig.6), como a estrela que contracenava com o cartunista. Com o uso do rotoscópio, o salto que se observa na fluidez dos movimentos é evidente e não surpreende que o palhaço tenha se tornado uma mania nacional e seu criador, Max Fleisher, uma celebridade. No comentário da New York Times, em 22 de fevereiro de 1920, a respeito da série em questão, nota-se a percepção de que nas linhas do desenho havia uma presença humana: "Os movimentos de Koko são suaves e graciosos. Ele dança e salta como um ser humano [...]. Ele não salta de uma posição para outra, e não move uma parte do corpo enquanto o resto permanece parado - como se estivesse fixo no papel." ${ }^{\prime 10}$ (apud CRAFTON, 1993, p. 174).

10 “The Inkwell man, New York Times, February 22, 1920. 
Além do rotoscópio, os irmãos Fleischer inovaram na criação do posto do intervalador, pela necessidade de se produzir mais rapidamente. Com Randolph Bray, os assistentes desenhavam a parte estática do personagem, da movimentação de apenas um membro do corpo, enquanto que o animador sênior, fazia todos os desenhos das partes móveis. Já na empresa dos Fleischer, diferentemente, o animador chefe desenhava as posições principais dos personagens, os pontos de inflexão, determinando o número de desenhos intermediários entre essas posições. O resultado era um ganho em rapidez e em expressividade.

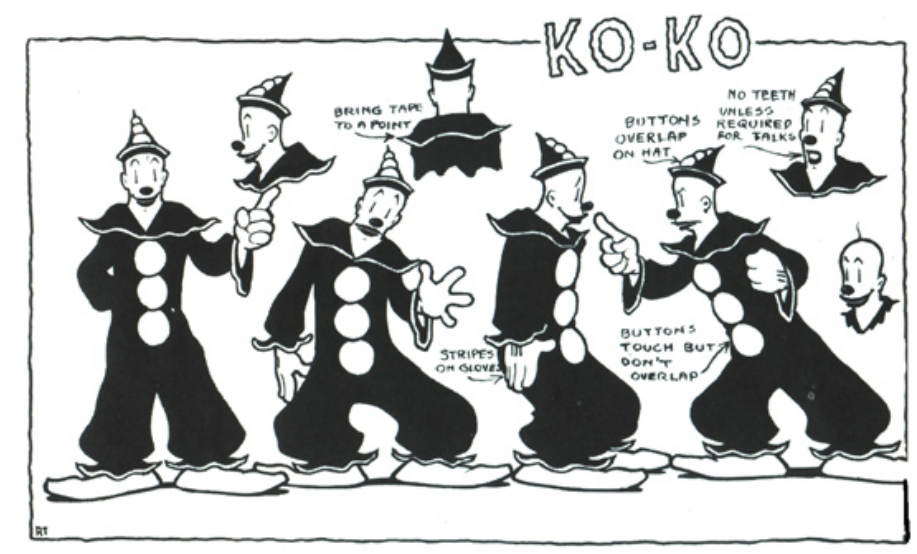

Figura 6 - diversas expressões do Palhaço Koko

Outra técnica de apropriação de imagem bastante empregada pelos animadores, é o uso do espelho na observação de expressões faciais. Conforme a necessidade da cena, o animador pode atuar em frente a um espelho para observar sua própria expressão e emprestála ao personagem que ele está desenhando. $\mathrm{O}$ animador-ator recorre a um referencial concreto, tridimensional, e sua percepção se encarrega de captar a essência da emoção a ser trabalhada e transpô-la para o plano bidimensional.

Walt Disney - o amálgama de todos os processos, o advento do som e da cor

Quando Walt Disney foi para Hollywood, em 1923, a maioria dos estúdios de animação já usufruíam de todos os esquemas de produção vistos acima, mas muito ainda estava por ser feito em matéria de conquistas no campo da linguagem. Muitas das fórmulas já estavam desgastadas e os "exibidores procuravam em outras direções para manter as plateias rindo" (JOHNSTON; THOMAS, 1981, p. 23). O trabalho de Disney em desenvolver um produto audiovisual que, acima de tudo se comunicasse com o público com sofisticação e 
humor, resultou em uma renovação nos códigos visuais que em muito se ancoravam na representação, no acting dos personagens, no refinamento da linguagem e nas histórias.

Nesse sentido, segundo Fialho (2005, p. 15), a "Disney foi quem melhor representou a nova filosofia de produção em desenho animado". O primeiro animador que Disney contratou para a série de desenhos Alice's Wonderland, Ben Sharpsteen, em entrevista para o livro de Ollie Johnston e Frank Thomas, The Illusion of Life, comenta: "eu precisava de um emprego que me desse um futuro, e eu não via nada promissor nos estúdios. Mas Walt era diferente. Seu olhar para a animação e sua determinação em produzir um produto superior foram o grande atrativo para mim." (apud JOHNSTON e THOMAS, 1981, p. 30).

Na empresa de Disney, o investimento em melhorias técnicas e no aprendizado da equipe eram constantes, bem como o incentivo ao compartilhamento de experiências. Disney organizou aulas de modelo vivo e rapidamente percebeu que esboços rápidos continham uma expressão mais vívida e espontânea. A observação do movimento real e da natureza passaram a ser matéria-prima nas animações. Até então, "não havia tentativa de se imitar a ação real nem de caricaturá-la. O melhor trabalho feito antes por Winsor McCay, mas ninguém sabia como havia sido feito. Poucos desejavam melhorar, mas onde poderiam estudar? Quem poderia ensinar?" (JOHNSTON; THOMAS, 1981, p. 31).

Por conta disto, os animadores-chefe passaram animar com traços mais soltos, produzindo desenhos menos detalhados e acabados para ganhar em fluidez. Deste e de outros procedimentos renderam a divisão de trabalho que ganhou novos contornos e novas funções, como por exemplo o key clean-up (responsável por passar a limpo os rascunhos dos desenhos principais da animação para facilitar o trabalho do intervalador) e o layout man (responsável por planejar o filme, os enquadramentos, estabelecer os movimentos de câmera).

Se, por um lado, a divisão do trabalho e a implementação de um método de administração de estúdio baseado no taylorismo levaram o estúdio Disney à otimização da mão de obra e ao aperfeiçoamento técnico, por outro, a busca pela lucratividade e eficiência (além da pressão por qualidade técnica e criativa) por vezes levou as equipes de animadores, intercaladores, arte-finalistas ao descontentamento. A greve dos animadores em 1941, consequência de demissões em massa e de promessas de aumento não cumpridas, exemplifica um momento de crise no estúdio ${ }^{11}$.

A necessidade de profissionais aptos a trabalhar em seu estúdio moveu Walt Disney e seu irmão Roy a projetar uma escola de artes que provesse ao estudante as diversas

\footnotetext{
${ }^{11}$ No site libcom.org encontra-se um registro detalhado das motivações para as greves no estúdio de Walt
} Disney: http://libcom.org/history/1941-disney-cartoonists-strike (acessado em: 13/12/2012) 
habilidades necessárias aos profisssionais da animação. O início do projeto do California Institute of Arts deu-se na década de 60 e sua concretização, nos anos 70, depois da morte de Walt Disney. A CalArts, como é chamada, foi concebida como um centro multidisciplinar que permitisse o contato com todas as formas de arte.

Inovar a cada produção, fazendo uso disso no marketing dos filmes, sempre foi uma especialidade da empresa de Disney, sobretudo no período considerado como sua era de ouro (décadas de 1930 e 1940). A conquista do som sincronizado ilustra essa orientação: era o alarde de uma novidade estética resultante de desenvolvimento tecnológico quando do lançamento de Steamboat Willie, em 1928.

Em sua dissertação de mestrado, "A relação som-imagem nos filmes de animação norte-americanos no final da década de 1920: do silencioso ao sonoro", Ana Luiza Barbosa, (2009) analisa os códigos visuais desenvolvidos na época do cinema silencioso e como a adição do som representou uma revolução na linguagem do cinema de animação, de onde depreendemos que a sincronização do som com a imagem, uma necessidade que se impunha desde o êxito de The Jazz Singer, trouxe novas questões a serem resolvidas, até porque não era certo que o som vinha para ficar.

Às dificuldades técnicas somavam-se as questões relativas ao uso criativo do som, considerando que o público já estava acostumado aos códigos visuais cunhados para a indicação das falas e da ruidagem e não "a ouvir vozes de desenhos [...]. Os animadores estavam preocupados que aquilo pudesse parecer aberrante, estranho e fora do lugar". (GABLER, 2009, p.143 apud BARBOSA, 2009, p. 54). Mas Disney estava convencido de que o som colocaria o estúdio novamente num patamar superior aos seus concorrentes. Embora outros estúdios também estivessem trabalhando no som (BARBOSA, 2009, p. 63) foi Disney quem obteve sucesso na combinação de imagens feitas para a música. Excluída a questão de qual sistema sonoro adotar - o custo mais baixo levaria Disney a optar pelo sistema óptico Powers Cinephone - haveria que se desenvolver um método de trabalho que integrasse as equipes de som e de imagem de maneira a garantir a precisão da sincronia, o que foi alcançado criando-se uma ficha de animação derivada de uma pauta musical (BARBOSA, 2009, p. 57).

Disney obteve a empatia imediata com o público, apresentando cenas com som realista, "como se o barulho estivesse vindo direto das coisas que o personagem fazia" (GABLER, 2009, p. 143 apud BARBOSA, 2009, p. 55). Nesse sentido, o sucesso deste empreendimento dependeu não apenas das questões técnicas, mas da adequação da nova linguagem à narrativa 
- a que o som poderia acrescentar e não apenas redundar - isto é, do uso criativo do som, como apontou a crítica na época. (BARBOSA, 2009, p. 72).

Assim como o som, a cor agrega ao filme mais um componente estético com o qual o cineasta/animador tem de lidar criativamente e fazer bom uso das suas possibilidades. A colorização de filmes já ocorria desde os primeiros tempos da película fotográfica e pesquisas em torno de processos de colorização corriam paralelas às pesquisas sonoras. Em 1895, Thomas Edison fez Annabelle's Dance colorido a mão, para exibição em kinetoscópio. Georges Méliès tinha um departamento de pintura manual de filmes e oferecia as películas em versão colorida por um custo adicional. Mas os primeiros a desenvolver um sistema economicamente viável de colorização foram os irmãos Pathé, utilizando o processo de estêncil, em 1905. Em 1910, no seu auge, eles empregavam cerca de 400 mulheres no departamento de estêncil. Durante a era do cinema silencioso, o sistema de tingimento, em que a película recebe um banho de tinta resultando monocromática, foi bastante popular ${ }^{12}$. Recentemente, em 2012, revelou-se um material de 1902 filmado por Edward Raymond Turner $^{13}$, que se aproxima do processo Technicolor por capturar a imagem em três cores vermelho, azul e verde - que, sobrepostas, resultam em uma coloração próxima à natural. $\mathrm{O}$ processo de Turner não vingou pela falta de um projetor que alinhasse corretamente o registro das imagens, o que causava uma imagem borrada. Finalmente o sistema Technicolor foi patenteado, em 1915, e custava o triplo do preço dos filmes em preto e branco.

Quando, em 1932, Walt Disney realizou Flowers and Trees, a cor era um elemento fundamental para esta história e Disney firmou com a Technicolor um contrato de exclusividade durante dois anos pelo uso do sistema de três cores (JÚNIOR, 2005, p. 108). Desta forma, Disney colocou-se à dianteira, posição que se manteve por décadas, tornando-se referência onipresente no cinema de animação - o que pode ser entendido de maneira positiva ou não.

Filmes de efeitos, stop motion e técnicas alternativas

Se a técnica do desenho animado reuniu condições de produção para florescer e atingir um grande público, o mesmo não aconteceu com a animação quadro a quadro, ou stop motion, técnica que resiste mais à divisão de trabalho, ainda que diversas obras - incluindo séries tenham sido realizadas desde o início do cinema.

\footnotetext{
${ }^{12} \mathrm{http}: / /$ en.wikipedia.org/wiki/Color_motion_picture film\#cite_note-8 (acessado em 02/02/2014)

${ }^{13} \mathrm{http} / / / \mathrm{www}$. telegraph.co.uk/culture/film/film-news/9538882/Worlds-first-colour-film-unveiled.html (acessado em 02/02/2014)
} 
Conforme Céu d'Elia (1996) ${ }^{14}$ reflete, o desenho animado é a forma mais difundida de cinema de animação devido a imperativos de produção e mercado que justificam o investimento com possibilidade mais garantida de retorno. Nas palavras de Richard Williams (2001), trata-se de uma arte industrial.

Como já foi dito, produtores de desenho animado aceleram-se nas pesquisas por mecanismos de agilização do trabalho. A animação quadro a quadro, por sua vez, requer um enorme tempo gasto com trabalho executado de maneira artesanal, sem perspectivas de automação para a produção em série ${ }^{15}$.

Mesmo assim, na primeira década do século passado, sabe-se que algumas obras elaboradas sobre esta técnica tiveram êxito, pelo menos até que viesse a público o segredo de como os objetos se moviam por conta própria. Em 1907, The Haunted Hotel, de Stuart Blackton, feito nos EUA e considerado o primeiro filme animado, o mistério da movimentação autônoma causava espanto e engrossava filas de espectadores curiosos para identificar o truque. Léon Gaumont, da produtora e distribuidora Gaumont, ordenou que os diretores da casa descobrissem o mistério do movimento dos objetos sem a mão humana; o recém-chegado à companhia Emile Cohl foi quem decifrou o segredo: cada giro da manivela permitia a exposição de apenas uma imagem. Assim, o diretor movimentava sucessivamente os objetos giro após giro. (CRAFTON, 1993, p. 18).

A descoberta da técnica da animação quadro a quadro deu-se em algumas localidades, como França, Inglaterra e Espanha, de forma mais ou menos concomitante e em alguns casos, casualmente. Haunted Hotel foi inspiração para muitos filmes que exploravam este efeito: Hotel Eléctrico, Sculpteur Moderne, The Hand of the Artist, entre outros. Os filmes de efeito fizeram muito sucesso durante o período em que o público não compreendia a natureza do movimento autônomo a que assistia. Conforme passou a circular pela imprensa o funcionamento da técnica, o público desinteressou-se gradativamente.

Além de sua aplicação em filmes de efeito, o quadro a quadro também teve realizações com bonecos no início do século XX. Na Rússia, Ladislas Starewich trabalhou com insetos embalsamados cujas articulações foram feitas de arame em seus primeiros filmes, obtendo resultados que impressionaram a imprensa internacional da época. Com o filme The Cameraman Vengeance, de 1912, Starewich desenvolveu uma narrativa flaubertiana, com desejo e traições envolvendo um casal de besouros, uma libélula e um gafanhoto. Mais tarde,

\footnotetext{
${ }^{14}$ BRUZZO, C.; FALCÃO, A. R. et al. (Coord.). Coletânea Lições com Cinema. São Paulo: FDE, Diretoria de Projetos Especiais/ Diretoria Técnica, 1996. 4 vol., p. 145.

${ }^{15}$ Este panorama modificou-se com a inclusão da computação, em meados da década de 1990, com as impressoras 3D gerando modelos e bonecos com diferentes expressões em série.
} 
em 1930, Starewich realizou The Tale of the Fox, com bonecos primorosos de personalidade antropomórfica.

Em 1921, o estúdio dos irmãos Fleischer incluíram cenas de animação quadro a quadro em um dos únicos curtas-metragens da série Koko intitulado Modeling, como estratégia de apresentar a cada filme um elemento surpresa. Este foi um dos poucos filmes nesta técnica durante a década de 1920.

Nos EUA, Willis O'Brien foi quem trabalhou o quadro a quadro com bonecos; sua pesquisa e sua modelagem incrivelmente realista trouxeram para o público o universo dos dinossauros. The Dinossaur and the Missing Link, de 1925, contou com bonecos feitos de borracha e com esqueletos de arame. Sua carreira prosseguiu com a realização de filmes de dinossauros e, em 1933, confeccionou e animou o boneco de King-Kong.

A virada dos anos 1940 para os 1950, então, marcou a entrada da televisão nas casas dos norte-americanos (10 anos depois no Brasil) e trouxe um aumento na demanda por conteúdo a ser exibido na nova mídia. No caso da animação, as séries apresentadas em salas de cinema foram reprisadas na TV. Com o esgotamento deste material, novas séries foram sendo criadas, em geral trazendo um trabalho de animação mais limitado em comparação com as animações para cinema. No caso do desenho animado tradicional, a UPA (United Production of America) inicia esta vertente - da chamada animação limitada - sem contudo perder em expressividade e conteúdo, vindo a ser provavelmente a melhor representante seguida por outras companhias, como Warner Bros e Hanna-Barbera.

Os processos que garantem a produtividade das séries (em sua maioria) não se reproduzem no âmbito da animação stop-motion, em que, por mais que se tenham funções desempenhadas por diferentes profissionais, o gesto do animador no momento da captura das imagens é único. Não obstante, a materialidade dos filmes com bonecos/objetos em quadro a quadro enseja uma experiência de fruição sempre original, um contra-campo ao mainstream nas grades de programação.

A possibilidade de produzir filmes na técnica de stop-motion em escala industrial séries, por exemplo - limitou-se a poucos realizadores que superaram barreiras impostas por um método prioritariamente artesanal de criação de bonecos e de cenários. É o caso do húngaro George Pal, que trabalhou em filmes de publicidade com bonecos na Europa antes de imigrar para os EUA, onde produziu dezenas de filmes para a série Puppetoons, entre as décadas de 30 e 50; do americano Art Clokey, diretor do filme abstrato Gumbasia (1955), em plastilina, e criador do personagem GumbeeGumbee, no ar entre as décadas de 50 e 80; do italiano Francesco Misseri, co-criador junto com Lanfranco Baldi das séries Mio Mao, Red 
and Blue, entre outras, na década de 70; e do britânico Peter Lord, que conduziu a série Morph para a rede de TV BBC entre as décadas de 70 e 80 , e ao final desta criou a dupla Wallace and Gromit, em parceria com Nick Park.

Uma hipótese para o êxito dessas produções apóia-se no fato de terem narrativas sofisticadas apresentadas com leveza e extrema criatividade em sua linguagem visual. As séries que conquistaram audiência e garantiram continuidade foram desenvolvidas com simplicidade técnica e contaram com estruturas de produção baratas em relação à produção em live action, à exceção de Puppetoons. Mesmo com características muito específicas e diferentes estruturas de produção, elas foram eficazes na manutenção do público, possivelmente por transmitirem o que Tim Burton expressa a seguir:

Há algo de visceral em mover um boneco quadro-a-quadro... Há um caráter mágico nisso. Talvez você consiga uma animação mais suave com computadores, mas existe uma dimensão e uma característica emocional nesse tipo de animação. ${ }^{16}$

16 In PURVES, Barry. Animação Básica: Stop-Motion. Bookman, 2011, pg. 83. 


\section{Capítulo 2 - $O$ desejo de animar e a superação das limitações na animação brasileira}

Como foi possível observar até aqui, as estruturas de produção do cinema de animação nos EUA contaram com forte investimento em capital e em recursos humanos, num momento em que as bases da industrialização e da sociedade de consumo tomavam corpo.

Logo que aqui chegou, o cinema já foi entendido como um importante instrumento de registro e divulgação, sendo utilizado

[...] para prestar serviços a instituições públicas, propiciando a representação sintética da pujança econômica do interior do Estado para a massa urbana, alimenta assim sonhos de afirmação regional da massa heterogênea, que se unifica frente à tela brilhante, e também as ambições de liderança política nacional dos políticos paulistas que posam nos discursos de abertura e se apropriam das palmas entusiásticas que saúdam o fim da projeção. (RAMOS, 1987, p. 24)

Durante o período que foi conhecido como "Bela Época do Cinema Brasileiro", entre 1908 e 1911, os filmes de ficção, chamados filmes posados, ganhavam a preferência do público em relação aos filmes estrangeiros. Foi uma época em que a produção vinculada à exibição garantiu o crescimento dessa arte-indústria no país (MOURA, 1987, p. 45). É por volta deste período, 1907, que se tem registro de pequenas animações,

[...] charges animadas feitas por Raul Pederneiras para terminar a exibição dos cinejornais projetados nas salas de cinema. Em 1910, Alberto Botelho e Alberto Moreira lançam o curta em animação 'Paz e Amor', uma crítica aos acontecimentos da campanha civilista e ao governo do presidente Nilo Peçanha. [...] A animação foi pintada a mão (fotograma por fotograma), tendo suas projeções exibidas, de maneira pioneira no país, em cores. (NESTERIUK, 2011, p. 109)

O final deste período de vigor no nosso cinema veio com a entrada de investidores estrangeiros que adquiriram grande número de salas de exibição e passaram a trazer fitas americanas. No cenário internacional, EUA e Europa investem em pesquisas tecnológicas e no aumento da produção, levando à necessidade de novos mercados consumidores; paralelamente, a linguagem cinematográfica desenvolve-se, sofistica-se e o cinema gradativamente deixa de ser um entretenimento das plateias "aculturadas" para conquistar os mais letrados. Como menciona Roberto Moura na coletânea História do Cinema Brasileiro,

[...] a narrativa permite, com as conquistas de Griffith da continuidade espaço-temporal, o encontro da técnica com a linguagem cinematográfica industrializável. Este novo quadro exige grandes e regulares investimentos com esquemas de divulgação que gerariam o chamado star system, popularizando atores e tipos cinematográficos no mundo ocidental, e a possibilidade de conjugar empresários, distribuidores, e jornalistas locais aos interesses desse cinema internacionalizante. (MOURA, 1987, p. 45) 
De um modo geral, pode-se dizer que, desde o início de sua estruturação como indústria, o cinema nos EUA foi compreendido pelo governo norte-americano como setor estratégico para a afirmação de seu poder econômico junto a seus parceiros comerciais, através da veiculação de um life-style que estimulava consumo. Em face disso, esforços integrados na forma de facilitações governamentais e investimento massivo em tecnologia e em marketing, favoreceram a difusão do cinema norte-americano pelo mundo. Assim, a qualidade técnica e uma certa eficiência narrativa do cinema americano padronizaram-se num patamar muito além do que era possível de se realizar no Brasil de então.

As consequências foram arrebatadoras para o cinema brasileiro: muitas produtoras de cinema no Brasil encerraram suas atividades, muitos profissionais perderam seus empregos, restando aos distribuidores e exibidores as oportunidades no ramo do cinema, sempre atrelados às produções estrangeiras.

Nesse contexto de infertilidade do cinema em solo brasileiro, um cartunista se aventura a produzir o nosso primeiro desenho animado.

Trata-se do Filme $O$ Kaiser, de 1917, de Álvaro Marins mais conhecido como Seth. O jornal $A$ Noite ${ }^{17}$ noticiou sem grande alarde, mas a comparação com a animação americana foi inevitável:

A caricatura animada em cinematógrafo só agora começa a ser explorada mais ou menos sistematicamente pelos americanos. Aliás, as melhores no gênero têm sido produzidas pelos yankees. As primeiras, ao que parece, exibidas entre nós foram feitas por um célebre desenhista do New York Herald para a fábrica Vitagraph, e, segundo o próprio filme, por aposta. (apud MORENO, 1978, p. 65)

$O$ Kaiser apresenta Guilherme II, imperador alemão, brincando com um globo terrestre - numa alusão à ousadia de querer dominar o mundo - o qual cresce e o engole. Seth que, assim como Emile Cohl e Winsor McCay, vinha da imprensa escrita, onde suas ilustrações e caricaturas já eram populares, voltou-se ao trabalho de ilustração publicitária para garantir seu sustento, após O Kaiser permanecer apenas dois dias em cartaz, de 22 a 24 de janeiro de 1917 (MORENO, 1978, pg. 67-68). Não existe nenhuma cópia disponível do filme de Seth, apenas a imagem de um fotograma que apresenta Guilherme II em frente ao globo terrestre (fig.1). Não se sabe, por exemplo, se Seth montou uma mesa de luz, se inventou algum sistema de registro, ou como se equipou para a filmagem. Muitas questões pertinentes à aquisição da técnica permanecem em aberto. No caso de Seth, o que se tem é

\footnotetext{
${ }^{17}$ A Noite, 13 de janeiro de 1917.
} 
uma entrevista para a revista Cinearte $^{18}$, em 1930 em que Seth já alerta para o fato de que a qualidade só é possível com "financiamento e material adequado [...] coisa que já acontecia entre os americanos, e que aqui, as informações técnicas demoravam muito a chegar." (apud MORENO, 1978, p. 67).

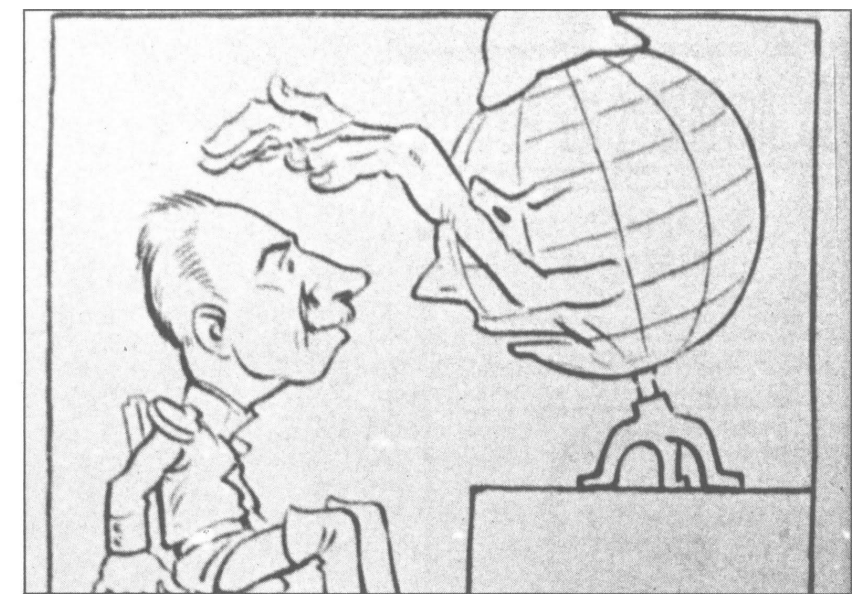

Figura 1- única imagem que restou do filme O Kaiser, de 1917, publicada na revista Cinearte em maio de 1930.

Em meio a produções esparsas no tempo, o desenho animado de propaganda é o que prevalece como oportunidade de aprimoramento técnico. Depois de Seth, ainda em 1917, Loureiro e Storni - advindos dos quadrinhos - fizeram Traquinices de Chiquinho e Seu inseparável Amigo Jagunço, do qual também não restou nenhuma cópia, com personagens da primeira revista brasileira dedicada ao público infantil, a Tico-Tico (figs. 2 e 3). O menino Chiquinho e o cão Jagunço eram cópias de Buster Brown e Tige, personagens publicados no jornal americano New York Herald, criados em 1902 por Richard Outcault ${ }^{19}$.

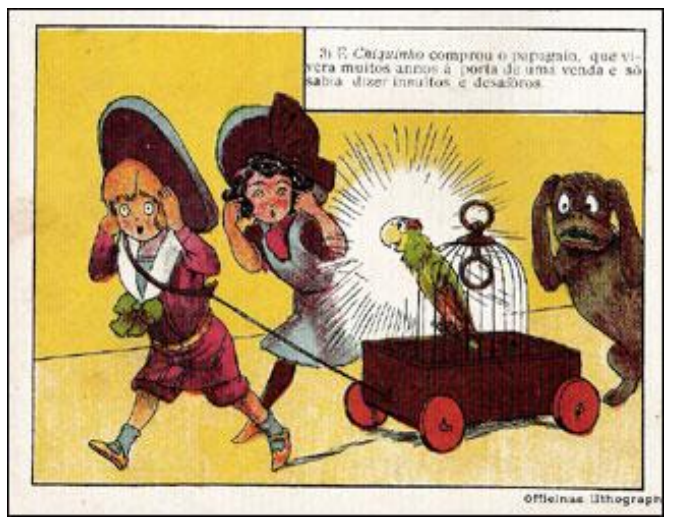

Figura 2 - Chiquinho (menino louro) e Jagunço, seu cão.

\footnotetext{
${ }^{18}$ O Desenho Animado do Cinema Brasileiro, revista Cinearte, 28-05-1930, pgs. 8, 9 e 38.

${ }^{19}$ Richard Felton Outcault foi ilustrador e autor de tiras em quadrinhos; fonte: http://www1.spbancarios.com.br/rdbmateria.asp?c=512\#topo (acessado em: )
} 


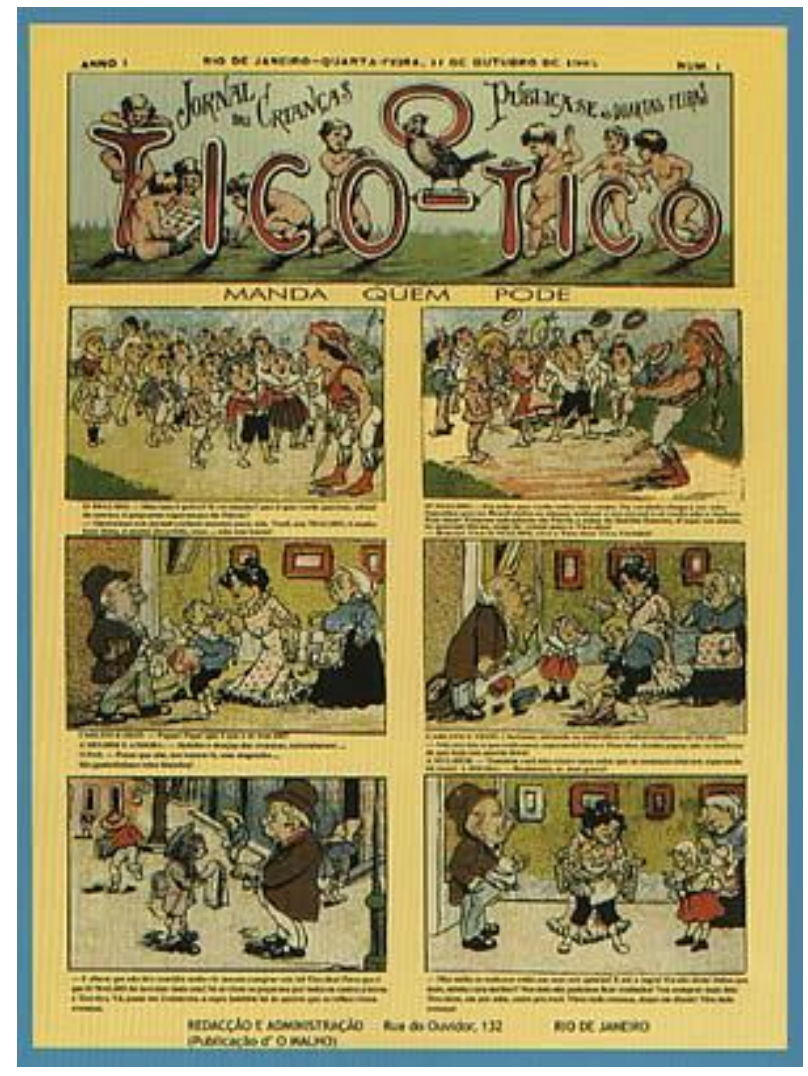

Figura 3 - página da revista Tico-Tico de 31/06/1912.

Outra experiência em animação de que se tem notícia aconteceu entre 1915 e 1918. O sorocabano Eugênio Fonseca Filho, conhecido como Fono,

"[...] iniciou a série, Frivolidade, de pequenas animações com seus dois personagens Bille e Bolle, inspirados em Mutt and Jeff, dos quadrinhos americanos. Um dos filmes de que se tem registro mais preciso é Aventuras de Bille e Bolle, de 1918, com desenhos de Fono, produção da Rossi Film e fotografia de Gilberto Rossi." ${ }^{20}$.

Assim como $O$ Kaiser, não há cópias destes filmes.

Durante um longo período, entre 1918 e 1929, houve alguns inserts de animação em cinejornais e alguma publicidade. O realizador Luiz de Barros, artista de múltiplos talentos, cuja filmografia se estende de 1914 a 1980, realizou uma animação ilustrativa para o filme Operação do Estômago, de 1928.

O filme Macaco Feio, Macaco Bonito (fig. 4), realizado por Luiz Seel e João Stamato, entre 1929 e 1933, é um dos raros destas primeiras décadas que foi conservado e também traz personagens da revista Tico-Tico. Nota-se uma inspiração nos trabalhos norte-americanos,

\footnotetext{
${ }^{20}$ Extraído do texto de Antônio Moreno para a edição eletrônica da revista Filme Cultura no 61 , jul/ago/set/2013: <www.http://filmecultura.org.br/08/2013/animacao-brasileira-1908-1969-do-nascimento-aoacorde-de-batuque/> Acessado em 07-03-2014.
} 
mas com vários méritos, sobretudo no timming da ação e no humor. Luiz Seel também realizou o curta Frivolitá, em 1930, além de 6 pequenas charges animadas, compondo a série Brasil Animado em parceria com o caricaturista Belmonte.

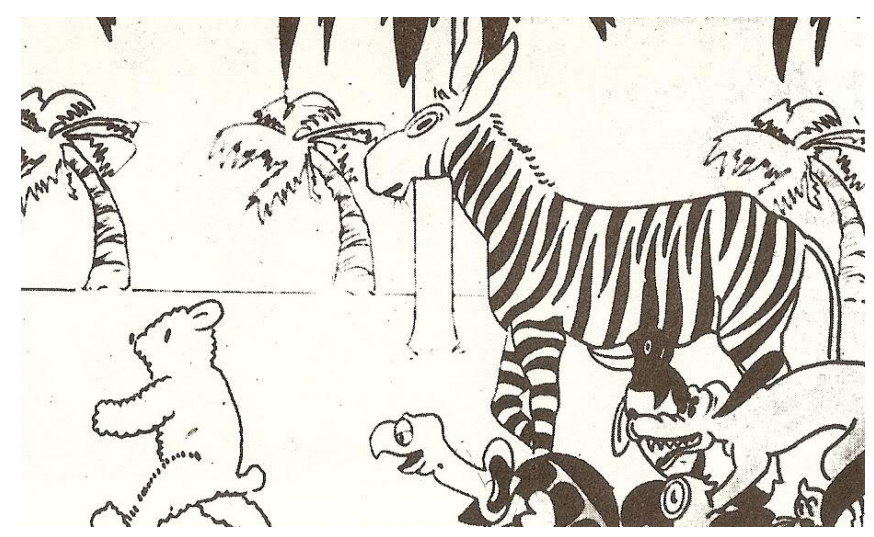

Figura 4 - fotograma do filme Macaco Feio, Macaco Bonito, de Luiz Seel e João Stamato ${ }^{21}$.

A respeito de Luiz Seel (fig.5), um cruzamento de informações entre o site da Cinemateca Brasileira, do IMDB e do Complete Index to World Film, leva-nos a verificar que este também foi um artista múltiplo: em Ganga Bruta, de Humberto Mauro, foi o técnico de som. Luiz (que em algumas fontes está como Luis, com S) realizou grande parte de sua filmografia - filmes em live action e vários outros curtas de animação - nos EUA.

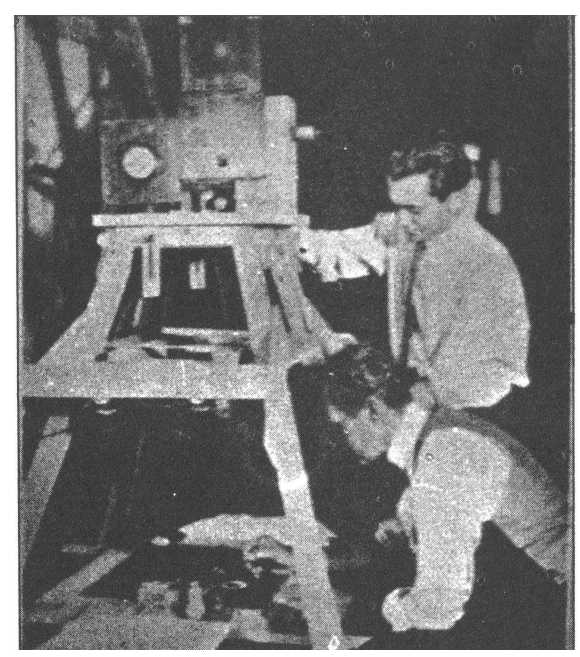

Figura 5: Luiz Seel e João Stamato no estúdio de animação ${ }^{22}$.

É de meados da década de 1930 à década de 1960 que a produção de filmes animados cresce paulatinamente e vários artistas se enveredam pelo campo da animação,

\footnotetext{
${ }^{21}$ Extraído de: $<$ http://brasilannima.blogspot.com.br/2011/08>. (acessado em: 13/11/12).

${ }^{22}$ Extraído de: $<$ http://brasilannima.blogspot.com.br/2011>. (acessado em 05/10/2012)
} 
especificamente em desenho animado tradicional. As soluções técnicas e o desenvolvimento do método de trabalho sempre tiveram como tônica a adequação da linguagem aos recursos disponíveis. Observa-se, assim, que em muitos casos o animador é também quem produz e fotografa os filmes, dada a falta de mão de obra especializada.

Em 1938/39, por exemplo, o cearense Luiz Sá, um ilustrador que também se utiliza de personagens da revista Tico-Tico, produz e anima As aventuras de Virgulino e Virgulino Apanha.

O pesquisador Antonio Moreno (2013) $)^{23}$, que fez um importante levantamento da produção de animação brasileira desde os primeiros filmes, descreve no suplemento eletrônico da Revista Filme Cultura no 61 uma passagem frustrante para Luiz Sá:

Quando Sá realizou Virgulino, em 1939, o Brasil tinha como presidente Getúlio Vargas. Seu governo tinha um ferrenho órgão de censura, centralizado no DIP, Departamento de Imprensa e Propaganda do Estado Novo, que intervinha na produção de cinejornais e como órgão censor de espetáculos e eventos. Por esta época, chega ao Brasil Walt Disney, "embaixador" da "política da boa vizinhança" promovida pelo governo americano com o intuito de "estreitar" os laços entre os países das três Américas e angariar simpatia para a oposição à crescente política nazista de Hitler. [...] Luiz Sá, que produzira sozinho e com dificuldades seu curta e não encontrara distribuidor, imaginou que um encontro com Disney fosse uma troca cultural estimulante. No entanto, o DIP de Getúlio alegou que seu trabalho era muito "primitivo" para ser apresentado a Disney e impediu que ele visse o animador americano. Desiludido com o cinema de animação, Luiz Sá resolveu vender a única cópia que tinha do filme para uma loja de projetores de cinema. $\mathrm{O}$ dono cortou o filme em pedaços e ofereceu como brinde a quem comprasse um projetor ${ }^{24}$.

A experiência de Luiz Sá demonstra a desvalorização institucionalizada e crônica de que sofre a animação brasileira; a escassa produção nesse período engendra uma questãoproblema que afeta todos os segmentos do nosso audiovisual: a falta de mercado interno.

Em 1953, Anélio Lattini Filho contou com a ajuda de seu irmão, Mário Lattini, para durante seis anos produzir um marco na animação brasileira, Sinfonia Amazônica (figs. 6 e 7), o primeiro longa-metragem de animação feito no Brasil. Trazendo uma temática totalmente nacional - as lendas do folclore brasileiro - recebeu inúmeros prêmios dentro e fora do país. Apesar de solitário, Lattini trabalhou com rigor técnico, desde o estudo da flora amazônica para a composição dos cenários, até o uso de fichas de animação para a sincronização com o som. Claramente inspirado em Fantasia, de Disney, Lattini produziu os desenhos totalmente coloridos e por falta de recursos não conseguiu imprimir uma cópia colorida. Lattini não

\footnotetext{
${ }^{23}$ Referência.

${ }^{24}$ Revista Filme Cultura no61, jul/ago/set/2013: <www.http://filmecultura.org.br/08/2013/animacao-brasileira1908-1969-do-nascimento-aoacorde-de-batuque/> (acessado em: 11/01/2013)
} 
obteve permissão em utilizar O Guarani, de Carlos Gomes como trilha, tendo que optar por Schubert, Wagner e Rossini, entre outros, com participação do flautista Altamiro Carrilho. Recentemente este filme passou por um processo digital de restauração realizado por Cláudio Bueno, da O2 Filmes, que também realizou testes de estereoscopia com Sinfonia, obtendo bons resultados.
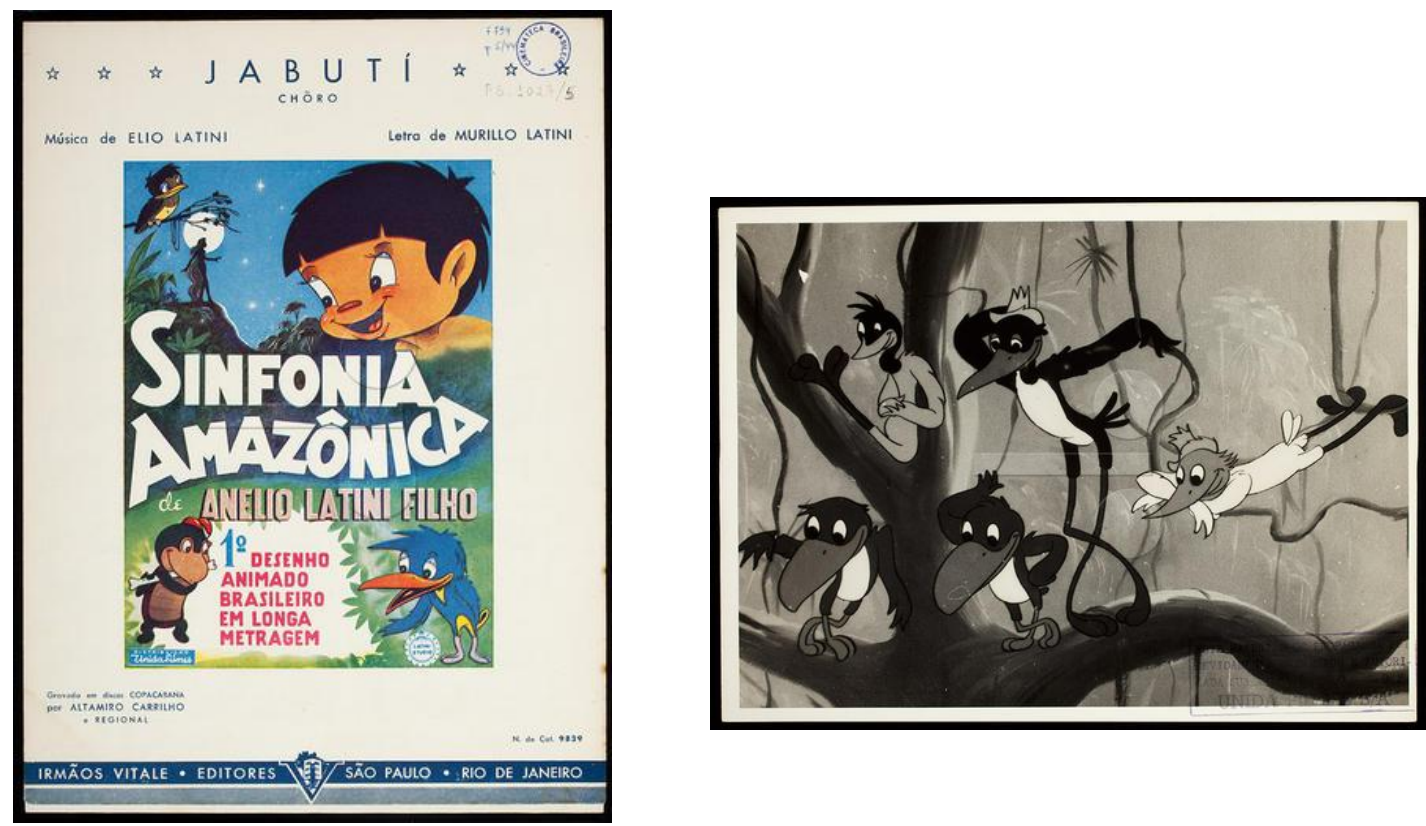

Figuras 6 e 7- cartaz e fotograma de Sinfonia Amazônica.

No final dos anos 1950 forma-se o Centro Experimental de Ribeirão Preto ${ }^{25}$, um coletivo de artistas, dentre os quais Roberto Miller, dedicado à produção de animação experimental. Mesmo com diversos filmes premiados em festivais, o grupo durou pouco tempo. Roberto Miller, foi o mais produtivo do grupo, introduzindo, entre outras, a técnica do desenho sobre a película (fig. 8 e 9), aprendida durante seu estágio no National Film Board do Canadá.
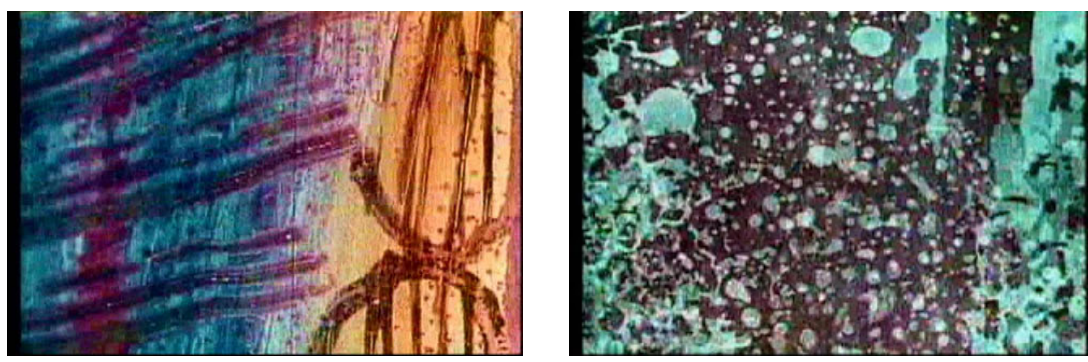

Figuras 8 e 9 - fotogramas de filmes de Roberto Miller.

\footnotetext{
${ }^{25}$ Em "A experiência brasileira no cinema de animação", Antonio Moreno (1978) relata todos os integrantes do grupo e seus respectivos filmes.
} 
Outros grupos se formaram ao longo dos anos 1960, como o CECA (Centro Experimental de Cinema de Animação), de 1967, e mais tarde o Fotograma, com alguns remanescentes do CECA, sempre com a preocupação de investigar novos materiais, mesmo que precariamente. Nesse ponto, vale fazer uma breve exposição da época que precede o período focado nesta pesquisa.

O surgimento, então, dos grupos de animação pode ser entendido como reflexo da atmosfera de pujança cultural vivida principalmente nos anos do governo de Juscelino Kubitschek, de 1956 a 1961. Trata-se de um momento especial na produção audiovisual brasileira, em que o país passa a ser visto e registrado de um modo diferente. É notável que esse movimento surja num ambiente de importantes transformações socioeconômicas no Brasil, como resposta a um modelo de cinema brasileiro que não se sustenta enquanto indústria, paralelamente ao fato da TV passar a integrar o ambiente cultural, ainda que na época a TV não fosse entendida como cultura, mas como diversão popular.

O cinema de animação, habitualmente destituído de espaços para exibição e reflexão, ganha status de expressão artística. Assim, o I Festival Internacional do Cinema de Animação no Brasil, que aconteceu no MASP (Museu de Arte de São Paulo Assis Chateaubriand) em 1965, deu acesso aos animadores e ao público a obras brasileiras e internacionais. O festival concentrou toda a produção do Centro Experimental de Ribeirão Preto, além de curtas de Ippê Nakashima, Roberto Miller, entre outros.

Toda esta atividade autoral e/ou independente convive com a produção de filmes didático/documentais patrocinados pelo Instituto Nacional do Cinema Educativo (INCE), criado em 1937 por Roquette-Pinto durante o governo de Getúlio Vargas ${ }^{26}$, que em 1966 transformou-se em Instituto Nacional de Cinema (INC). As animações H2O (1962), Inflação (1966), O Milagre do Desenvolvimento (1968) e a série Alfabeto Animado, produzidas pelo INC, são exemplos dessa produção estatal que frequentemente contavam com mão de obra advinda da publicidade, como a de Guy Lebrun e a de Daniel Messias. A relação entre a produção para publicidade e essa produção paralela não comercial mereceu uma reflexão interessante, proposta por Marina Estela Graça (2006, p. 17), pesquisadora portuguesa do cinema de animação:

No âmbito das produções mais ou menos comerciais, é visível o maior ou menor respeito dos autores pelas convenções de linguagem e pelas normas profissionais, procurando aproveitar essas possibilidades - socialmente estabelecidas - a fim de produzirem fisicamente filmes que se constituem,

\footnotetext{
${ }^{26}$ O número 49/2007 da revista Filme Cultura é uma edição comemorativa dos 70 anos do INCE.
} 
sobretudo, como processos de comunicação. Estes, assim como as regras, padrões técnicos e processos convencionais que integram o todo do dispositivo fílmico, compõem o contexto no qual é possível explorar, decifrar e experimentar processos novos de linguagem fílmica. São a base a partir da qual é possível tentear percursos. Não há, portanto, filme animado de autor sem filme animado comercial ou, em sentido lato, cinema de massas, compreendido este na totalidade de seu aparato técnico e ideológico.

O cinema comercial mencionado por Graça não coincide exatamente com o cinema de animação publicitário estudado nesta pesquisa, mas com aquele mais comumente presente nas salas de exibição. No entanto, por ser um cinema comprometido com a comunicação de uma mensagem específica - e com um padrão de decodificação pré-estabelecido -, compartilha com o que estamos estudando aspectos semelhantes em seu processo produtivo. A simbiose criativa assinalada por Graça entre o filme de animação de autor - que entendemos como uma vertente mais experimental e independente da animação - e o filme comercial concretiza-se na alternância de atividade de vários animadores brasileiros, os quais buscavam no comercial a sobrevivência e a aquisição de técnica e recursos para a viabilização de seu trabalho autoral. Anélio Lattini Filho, Ippê Nakashima e Roberto Miller são alguns dos profissionais que exemplificam esta atitude.

A propósito de Ippê Nakashima - cujo portfólio inclui Lenda da Vitória Régia e $O$ Gorila, de 1957 e 1958, respectivamente - sabe-se que ele estabeleceu na produção de Piconzé (fig. 9), lançado em 1972, um esquema de trabalho mais próximo da produção industrial, com as devidas adaptações para a nossa realidade econômica.

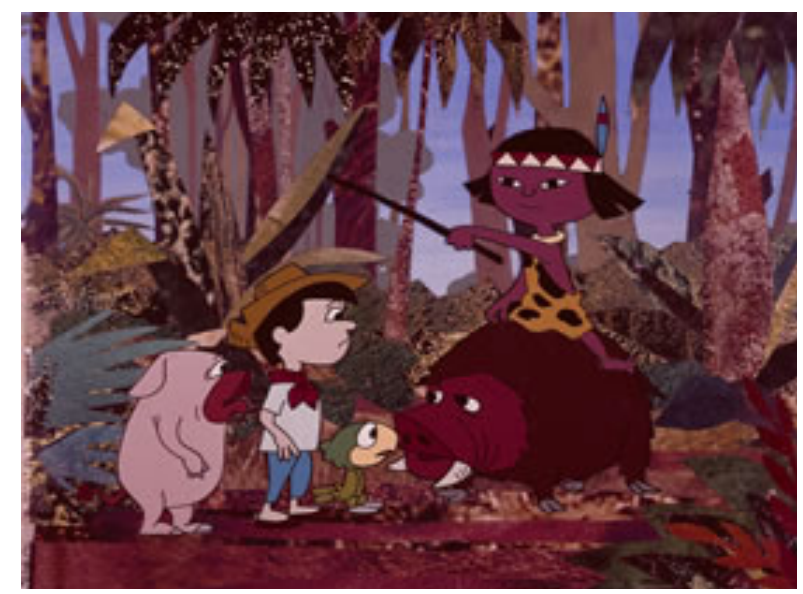

Figura 9 - fotograma de Piconzé.

De acordo com a catalogação da Cinemateca Brasileira, a produção de Piconzé contou com sete animadores. Trazendo experiência da animação publicitária, Ippê trabalhava nas horas vagas com pontas de película que sobravam de seus trabalhos comerciais. Foi o 
primeiro longa-metragem de animação em cores no Brasil. Ippê inovou na direção de arte ao criar os cenários das cenas com colagens de fotografias, no lugar de paisagens pintadas. A trilha musical orquestrada de modo a dar o humor (andamento) de cada cena, conta com canções cujas letras são de Décio Pignatari.

No campo da animação experimental, como já foi dito, Roberto Miller mantém uma linha de trabalho fortemente influenciada pelo designer gráfico Saul Bass e pelas técnicas aprendidas com Norman McLaren nos anos 1950. Sua intimidade com a película e seu estilo gráfico moderno levaram-no a realizar muitos filmes abstratos e também letreiros para filmes de longa metragem, como Lampião, o Rei do Cangaço, Meu Japão Brasileiro e O caso dos Irmãos Naves. Mais tarde, já como diretor de TV, nos anos 1980, Miller será responsável pela memória e pela difusão de animação brasileira e internacional no programa Lanterna Mágica.

Nas décadas de 1950 e 1960, um fator que contribuiu para o fortalecimento da animação foi a popularização da TV. Observa-se que nesse período alguns dos futuros animadores de prestígio no meio comercial iniciaram suas carreiras, como é o caso de Joaquim Três Rios, de Daniel Messias e de Walbercy Ribas, três dos realizadores cujas trajetórias serão analisadas nesta pesquisa. Os três produtores-animadores têm em comum o fato de se valerem (em variadas escalas) do improviso ${ }^{27}$ em suas primeiras experiências, dando ênfase ao desenho e à expressão, na busca por viabilizar seu negócio. Nesse aspecto, o improviso tange o experimental, a pesquisa para se obter determinado resultado. Também compartilham o fato de se consolidarem nas décadas de 1970 e 1980 como nomes sólidos na animação.

\footnotetext{
${ }^{27}$ Walbercy Ribas conta que sua primeira mesa de animação foi feita com um caixote de frutas de madeira, por exemplo. Joaquim Três Rios relata as filmagens numa truca cujo eixo vertical era um cano de água de 2". (informar se a informação é verbal, pessoal, etc.)
} 


\section{Capítulo 3 - O método de produção do cinema publicitário nos anos 70 e 80}

\section{Contexto}

$\mathrm{Na}$ virada dos anos 50 para os 60 , a popularização da TV engendrou a demanda por conteúdos patrocinados por anunciantes em troca da exposição de suas marcas e produtos. Trata-se da consolidação de um ramo de negócios, o do cinema publicitário, iniciado já na época da imprensa escrita, no início do século XX, plasmado na era do rádio e absorvido pela $\mathrm{TV}$, num momento em que a programação televisiva e os filmes comerciais compõem uma grade bancada por empresas. O cinema de animação beneficiou-se desse caldo econômicocultural conjugado com um território a ser explorado livremente.

O animador Daniel Messias (2013, p. 2) comenta esse período e avalia que a propaganda brasileira foi alavancada pela combinação de dois fatores: o alto custo dos comerciais importados e o crescimento do mercado interno:

[...] foi na época de substituição da propaganda americana pela propaganda nacional. Porque as primeiras propagandas eram todas americanas, e se importava propaganda aqui. Quer dizer, quem tinha dinheiro prá bancar, como a Bardahl, por exemplo, trazia os filmes já prontos dos EUA. E quando ficou inviável, e o anunciante brasileiro começou a ter dinheiro prá investir em propaganda de TV, então começou a se criar um mercado interno aqui. (informação verbal) ${ }^{28}$

O surgimento e a consolidação de estúdios de desenho animado para publicidade, foi o momento em que alguns dos entrevistados desta pesquisa estreavam no cinema de animação, em sua maioria na Lynx Films.

Criada em 1958 em São Paulo, por César Mêmolo Jr., a Lynxfilm foi uma das três produtoras mais importantes nos anos 1960 e "juntamente com a Jota Filmes, de Jacques Deheinzelin e John Waterhouse, e com a produtora de comerciais de Gilberto Martins, formava o tripé básico que impulsionou o cinema publicitário paulista." (em fase de elaboração $)^{29}$.

Assim, a Lynx absorveu muitos dos antigos profissionais e técnicos de cinema da extinta Vera Cruz e, ao colocar o pessoal novato em contato com os veteranos, representou para os profissionais em início de carreira uma verdadeira escola, tanto em filmes "ao vivo" como em animação.

\footnotetext{
${ }^{28}$ Entrevista concedida por MESSIAS, Daniel. Entrevista III. [jan. 2013] São Paulo. Entrevistador: Maria Luiza Dias de Almeida Marques. 2013. A entrevista na íntegra encontra-se transcrita no Apêndice C desta monografia.

${ }^{29}$ TEDESCO, Cybelle. Lynxfilm - uma contribuição à memória do audiovisual paulista. A ser editado pela UNCAMP, 2012.
} 
Eu passei pela Lynx Filmes, que foi a grande produtora; eu acho que essa foi a grande escola de animação no Brasil e é estranhamente ignorada. A Lynx Filmes ainda merece um exame profundo dessa experiência, não só em animação, de cinema ao vivo até de laboratório; realmente foi uma coisa paradigmática. (informação verbal) ${ }^{30}$

No mesmo ambiente circulavam, por exemplo, gente como Galileu Garcia, Roberto Santos e Chick Fowle, que trabalhava na tru com Marcello Tassara. Rui Perotti Barbosa, por sua vez, montou o departamento de animação, por onde passaram os jovens Daniel Messias, Walbercy Ribas, Joaquim Egydio de Trez Rios, mais conhecido como Joaquim Três Rios (este, por um curto período), dentre outros. Essa era uma geração de jovens com talento para artes que não se encaixava em profissões tradicionais, como lembra Ribas (2013, p.1):

Não existia nenhuma faculdade em que eu me interessasse, porque eu não queria ser engenheiro, médico, advogado, dentista, nada disso, eu queria ser artista somente, né, e o artista já nasce com a sua universidade pronta, ele vai só desenvolvendo, é um talento, a universidade da gente é o talento que Deus dá prá gente $[\ldots]$ o mercado fervia de novidade e havia uma carência profissional como sempre há carência profissional no Brasil, e de repente eu comecei num estúdio de animação chamado Lynx Filmes; era uma produtora grande que fazia filmes ao vivo, mas tinha o departamento de animação. De repente, eu entrei lá fazendo arte final, e, em três meses eu fiz o primeiro filme da minha vida, inteiro, quer dizer, por completo. (informação verbal) ${ }^{31}$

A Lynx, que também contava com laboratório de revelação, dividia o mercado de comerciais animados com a Dinamic Filmes (de onde saiu Luis Briquet), do francês Guy Lebrun, e com a produtora de Léo Pastro, o primeiro estúdio onde Joaquim Três Rios trabalhou. Este ressaltou a superioridade técnica da Lynx, onde já se trabalhava com mesas de luz enquanto que na Léo Pastro usava-se papel vegetal e prancheta com 2 pinos.

Se por um lado a Lynx representou para muitos profissionais a entrada no metiê do cinema de animação, por outro, aos poucos ela se tornou pequena frente às aspirações de vários deles, como relata Messias, que lá permaneceu de 1960 a 1967:

[...] em 1967, a Lynx começou a exaurir, [...] , ela virou muito mercantil, então eles estavam fazendo filmes que não me interessavam, filmes de varejo, eu comecei a sentir que as perspectivas eram ruins prá mim, de futuro; eu era um jovem ainda, dominando animação, eu tava realmente tinindo como animador, e eu queria fazer alguma coisa diferente, e eu percebi que não havia condições na Lynx Filmes. (informação verbal) ${ }^{32}$

E, ao final da década de 1960, todos vindos do bairro de Santana, na zona norte da

\footnotetext{
${ }^{30} I d ., 2013$, p. 2.

${ }^{31}$ Entrevista concedida por RIBAS, Walbercy. Entrevista II. [ago. 2013] São Paulo. Entrevistador: Maria Luiza Dias de Almeida Marques. 2013. A entrevista na íntegra encontra-se transcrita no Apêndice B desta monografia.

${ }^{32}$ Entrevista concedida por MESSIAS, Daniel. Entrevista III. [jan. 2013] São Paulo. Entrevistador: Maria Luiza Dias de Almeida Marques. 2013. A entrevista na íntegra encontra-se transcrita no Apêndice C desta monografia.
} 
capital paulista, Daniel Messias, Walbercy Ribas e Joaquim Três Rios estabelecem-se como empresários autônomos, definindo padrões estéticos e uma certa conduta profissional que passaram a ser adotados por grande parte das empresas do ramo da indústria criativa.

Vale, entretanto, dar um passo para trás na cronologia dos fatos para retomar as trajetórias destes animadores-empresários, a fim de compreender o mecanismo pelo qual conquistaram a autonomia para a criação de suas empresas, bem como o pensamento que os guiava na busca pelas realizações profisssionais. O percurso adotado nesta pesquisa se inicia com a formação dos animadores, seus primeiros empregos e sua bagagem cultural.

A escolha pela animação representou, para os entrevistados deste primeiro grupo, a escolha natural relacionada aos interesses que esses jovens nutriam por desenho, cartoon e cinema. Numa época em que não havia curso de animação e as informações técnicas eram escassas, o sujeito que se dispusesse a penetrar no métier da animação teria que contar com alguma inclinação nata para as artes - o que Ribas chama de talento - e com o garimpo de oportunidades e equipamentos.

Filho de desenhista amador, Joaquim Três Rios (2012, p. 2) não se considera tão bom quanto seu pai no desenho: "Meu pai era um excelente desenhista, muito melhor que eu; eu era um rabiscador, um garatujeiro, quebrava um galho, em terra de cego dava certo." (informação verbal) ${ }^{33}$. A influência paterna levou-o a fazer exercícios de rotoscopia e testes de personagens de maneira intuitiva, em casa. Sua formação foi totalmente prática, como ele costuma brincar:

Eu se fiz por si póprio (sic). Fiz até o segundo ano colegial, parei, aí eu fiz 2 anos de desenho arquitetônico no Liceu de Artes e Ofícios, eram 4 anos, eu fiz 2 anos, aí eu conheci a minha mulher, casei, aí eu comecei a falhar nas aulas e parei, me arrependo amargamente até hoje, não fiz faculdade [...] Quando eu fiz esses filminhos aí, eu fiz tudo por intuição, eu não conhecia nada, eu, por intuição sabia como se fazia o desenho animado e ia procurar. (informação verbal) $^{34}$

A influência familiar também foi determinante na escolha profissional para Messias. Filho do ilustrador e chargista da Gazeta Esportiva, Messias de Melo, desenvolveu a aptidão para o desenho de maneira autodidata, cercado de mestres da ilustração e das charges de humor:

Eu era uma criança, com 10,12 anos; até os 14 anos, eu ia diariamente na redação com o meu pai, então, eu comecei a desenhar criar o gosto pelo

\footnotetext{
${ }^{33}$ Entrevista concedida por TRÊS RIOS, Joaquim. Entrevista I. [out. 2012] São Paulo. Entrevistador: Maria Luiza Dias de Almeida Marques. 2012. A entrevista na íntegra encontra-se transcrita no Apêndice A desta monografia.

${ }^{34} I d ., 2012$, p. 2.
} 
desenho. Depois, com o fim da Gazeta o meu grande mestre, meu grande professor, foi o meu pai, Messias de Melo [...]. Inclusive, na época de férias, eu substituía ele, eu ia lá e fazia a charge, eu tinha 12,13 anos de idade; fazia charges, depois ele dava umas broncas, em casa, quando ele via publicada no dia seguinte, e corrigia, etc. Eu praticava desenho natural, eles faziam sessões de desenho na casa desses ilustradores, na casa do [Jayme] Cortez, na casa do meu pai, mesmo; eu ia ao Zoológico, desenhava animais, fui treinando a anatomia humana e a anatomia animal com esse pessoal. (informação verbal) $^{35}$

Messias, por diletantismo intelectual, graduou-se em Sociologia na USP, de 1968 a 1972, o que ele próprio considera não se relacionar de nenhuma forma à sua profissão.

Uma experiência de vida radicalmente oposta conduziu Ribas à animação. Nascido e criado na zona rural, nada havia no universo familiar que o conduzisse a uma carreira artística. $\mathrm{Na}$ época em que fez seu primeiro filme, em 1959, Ribas tinha 16 anos. Ele entrou na Lynx para fazer arte final e em 3 meses já realizava seu primeiro filme, para as Lojas Pirani. Encerrou seu estudo formal ao término do colegial clássico, que combinava com seu gosto pelas disciplinas de humanas.

Nunca tive pai, mãe, alguém que falasse 'meu filho, siga este caminho'. Eu segui pelo faro, pelo sentido, nada do que eu fiz foi baseado em alguém ou em uma referência. Fazia colegial clássico, gostava mais de literatura e filosofia do que matemática e química ou biologia; eu terminei o clássico e ia começar a fazer a universidade, só que na época, eu não tinha dinheiro prá fazer faculdade [...] Então começou a surgir a FAAP; só que a FAAP era uma faculdade inatingível prá pobre, acho que até hoje, né? Aí, eu não ia fazer faculdade. Eu já estava me envolvendo cada vez mais com animação, eu sempre fui uma pessoa de família muito humilde, vim de fazenda, e eu não tinha condições de fazer faculdade. [...]

Quando eu fui pra animação, eu tinha, por coincidência, tinha um vizinho, chamado Eli Barbosa, que faleceu recentemente; ele viu que eu desenhava, e falou 'vou levar você fazer um teste lá na Lynx Filmes'. Eu fiz o teste e entrei. Lá eles eram animadores profissionais, e eu não. 'Tava lá, o Ruy Perroti, o Daniel Messias, o Marcello Tassara, no table top. Eu cheguei como franguinho lá, e comecei a fazer traço, essas coisas todas e, era tanto trabalho, que eles jogavam pro ar, e, quem pegar, pegou, faz o filme. Foi quando eu fiz o trabalho da Pirani. Foi aí quando eu comecei a fazer animação. Eu acho que eu entrei na animação, muito mais por necessidade de sobrevivência, do que porque eu amava animação tanto assim. Depois que eu passei a gostar. Era muito mais prá ter um emprego em desenho, né, do que paixão por animação. (informação verbal) ${ }^{36}$

No entanto, alguns pontos de convergência podem ser observados nestes animadores em relação ao desenvolvimento de seus métodos de animação e aos seus primeiros trabalhos.

\footnotetext{
${ }^{35}$ Entrevista concedida por MESSIAS, Daniel. Entrevista III. [jan. 2013] São Paulo. Entrevistador: Maria Luiza Dias de Almeida Marques. 2013. A entrevista na íntegra encontra-se transcrita no Apêndice C desta monografia.

${ }^{36}$ Entrevista concedida por RIBAS, Walbercy. Entrevista II. [ago. 2013] São Paulo. Entrevistador: Maria Luiza Dias de Almeida Marques. 2013. A entrevista na íntegra encontra-se transcrita no Apêndice B desta monografia.
} 
A intuição e a cópia são alguns deles.

Antes de seu primeiro trabalho profissional em animação, Joaquim Três Rios fez alguns filmes-teste da vodka Eristow usando uma antiga câmera Siemens $16 \mathrm{~mm}$ de seu pai. Seu portfólio, composto dos estudos de personagens, da rotoscopia e dos filmes de Eristow, compuseram o rolo que Joaquim mostrou a Léo Pastro, para quem passou a trabalhar inicialmente como freelancer, em 1960, paralelamente ao emprego de vendedor de crediário na prestigiada loja $A$ Exposição Clipper. Varando as noites e aproveitando o horário de almoço (depois de comer a marmita), Joaquim realizou na alfaiataria da loja, os desenhos animados da abertura de Papai Sabe Tudo e o comercial da imobiliária Predial de Lucca.

Assim como a rotoscopia caseira de Joaquim, Daniel Messias também fez testes com desenhos animados usando um dispositivo que permitia a colocação de desenhos com registro na Paillard Bolex 16mm de seu pai: "eu fiz um teste, mandei revelar na fotóptica, e a coisa se mexia. Aí foi um encantamento. Foi assim que eu aprendi a animar".

Também levado pelas mãos de Eli Barbosa, seu colega de escola, Messias montou na edícula da casa de seus pais, em Santana, um estúdio onde passavam o tempo desenhando e pesquisando a animação dos rolos de filmes que compravam. Até o dia em que um amigo de Messias de Melo o indicou ao que viria a ser seu primeiro trabalho comercial, para a loja de departamentos Três Leões, que tinham uma conta na Standard (atualmente Standard, Ogilvy $\&$ Mather):

[...] 'vocês vão lá que eles têm um filme prá vcs fazerem...', e nós fomos e realmente tinha um filme de 30 segundos pra Três Leões, que eu animei junto com o Eli, foi nosso primeiro filme... sonoro, em preto-e-branco ainda. (informação verbal) ${ }^{37}$

Neste primeiro trabalho de Messias, de 1958, o gosto pelo pelas animações da Metro, especialmente da dupla Hanna/Barbera, levou-o a criar um leão com a fisionomia do gato do seriado Tom\&Jerry. Esta afinidade com o desenho de cartoon transformou-se numa tendência estilística que determinou inúmeros de seus trabalhos futuros, sobretudo como estúdio autorizado a produzir com exclusividade no Brasil filmes comerciais com animações de personagens Looney Toones, Snoopy, Scooby-Doo, entre outros. Apesar desta experiência ter ocorrido sem a estrutura de uma produtora estabelecida, ela abriu espaço para a profissionalização de Messias, a qual se deu, de fato, nos tempos em que trabalhou na Lynx. Durante este período, Messias fez filmes para Maizena, Sadia, Varig (fig. 1), entre outros.

Em relação à estética da época, o animador comenta que o estilo Disney estava fora de

\footnotetext{
${ }^{37}$ Entrevista concedida por MESSIAS, Daniel. Entrevista III. [jan. 2013] São Paulo. Entrevistador: Maria Luiza Dias de Almeida Marques. 2013. A entrevista na íntegra encontra-se transcrita no Apêndice C desta monografia.
} 
moda. Modernos eram considerados os grafismos da UPA (United Productions of America) e da Escola de Zagreb, da Croácia, em que se via um design mais simplificado, geometrizado, e uma animação mais limitada, sem prejuízo da expressividade. Essas características se traduziram numa conveniência para o iniciante no mercado de animação publicitária paulistano, que, a despeito da perspectiva de crescimento, ainda operava com muitas limitações. Desta forma, a combinação do "útil com o agradável", é vista na animação econômica do comercial da Varig, com roteiro do Boni, em que Messias inspirou-se na linguagem geométrica dos letreiros de Saul Bass, designer responsável pelas aberturas de Vertigo, West Side Storyl, Spartacus, entre outros, caracterizada pela incorporação de elementos da narrativa aos letreiros, mescla de texto com desenhos de linhas expressivas, cores chapadas.

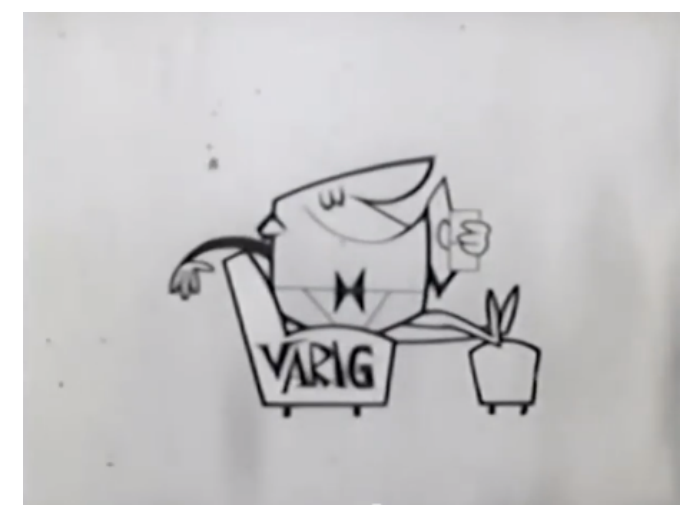

Figura 1 - imagem do filme Varig.

Após os sete anos de Lynx, Messias já tinha experiência suficiente para trabalhar como freelancer:

[...] a maioria das produtoras era de filme ao vivo, não tinha um departamento de animação, então, eu comecei a montar um pequeno departamento, no meu estudiozinho, que era uma salinha lá em Santana. Então, eu tinha um freelancer lá, que fazia o trabalho em acetato, filmava, eu tinha tinha câmera $35 \mathrm{~mm}$, já. Depois eu peguei uma mocinha que ajudava a pintar os acetatos também. Ou seja, a minha equipe era de 3 pessoas. (informação verbal) $^{38}$

A estrutura padrão de produção - pessoal e equipamentos - no anos 60 variava pouco entre as produtoras. A Leo Pastro Produções, por exemplo, contava com o animador Guy Lebrun (animador do Arroz Brejeiro) e com um stand de animação (table top, montado com um cano de 2" pelo próprio Pastro, que também operava o sistema na filmagem de desenhos

\footnotetext{
${ }^{38}$ Entrevista concedida por MESSIAS, Daniel. Entrevista III. [jan. 2013] São Paulo. Entrevistador: Maria Luiza Dias de Almeida Marques. 2013. A entrevista na íntegra encontra-se transcrita no Apêndice C desta monografia.
} 
animados). Não usavam mesa de luz para animar: em vez disso, usavam mesa de 2 pinos e papel vegetal. A equipe na Leo Pastro era mínima:

[...] eu trabalhava sozinho lá. Aí, um dia, nós contratamos uma filetista - que tinha saído do Guy, depois voltou pro Guy, nunca mais vi essa moça. Depois a equipe foi crescendo, contratou o Walbercy Ribas [em 1962] trabalhei pouquíssimo tempo com o Walbercy; outro cara, a gente chamava ele de Tom Bell, o Airton Gomes, fez um curta-metragem interessante naquela época. A equipe éramos eu o Walbercy e o Airton, tinha umas 4, 5 pessoas que a gente trabalhava lá, no fundo da casa lá. (informação verbal) ${ }^{39}$

Quando Lebrun deixou o estúdio de Leo Pastro para trabalhar com Jacques Deheinzelin, Pastro contratou Joaquim para ser o animador fixo da casa. Este, que acabara de ser promovido na Clipper, largou o emprego de Cr\$17.000,00 para ganhar Cr\$50.000,00 na Leo Pastro. Ainda que instável, esse mercado era promissor, com demanda crescente e poucos profissionais habilitados e equipados.

Trabalhando agora como contratado de Léo Pastro, Joaquim animou Julho nos States e Carta de Amor, ambos para a Varig, com criação da dupla Boni/Jarbas Agnelli, da Multi Propaganda. Na sequência de trabalhos, o filme Asas para a Varig foi o primeiro trabalho em animação gráfica de Joaquim; nele, ao som de uma locução feminina de aeromoça, vêem-se as partes que compõem a estrela da Varig em movimentos ordenados, com exploração da profundidade, às vezes em trajetória espiral, às vezes retilínea, sempre formando gráficos geométricos. Ao final, forma-se a estrela da Varig. Este trabalho destoa dos demais desta fase de Três Rios por não conter desenhos animados cartunescos, deixando-se notar a influência da linguagem gráfica de Saul Bass, novamente, bastante em voga na época. Para completar, os filmes de mais prestígio de Três Rios no estúdio de Leo Pastro, Esso Bossa Nova (fig. 2), de 1961, contava com trilha de Ari Barroso ${ }^{40}$.

Terminados os dois anos de trabalho firmados no contrato com Leo Pastro, Joaquim voltou a fazer trabalhos como freelancer, sozinho, para a Magison, para a Lynx filmes, entre outras, onde seu primeiro trabalho foi para a Parahyba (fig.3):

Quando me deram o Já é hora de dormir prá fazer, eu fui na Lynx, o César Mendes me disse: 'olha aqui: a trilha é essa', eu fui lá, marquei (o tempo d') a trilha, fui prá casa, fiz o filme no prazo que tinha, entreguei o filme, e o filme foi pro ar; e hoje em dia é um, sei lá, um 'AHH, esse filme!'... É só um filme, um trabalho, a gente faz um trabalho [...]

\footnotetext{
${ }^{39}$ Entrevista concedida por TRÊS RIOS, Joaquim. Entrevista I. [out. 2012] São Paulo. Entrevistador: Maria Luiza Dias de Almeida Marques. 2012. A entrevista na íntegra encontra-se transcrita no Apêndice A desta monografia.

${ }^{40} \mathrm{O}$ filme teve duas versões antes de ir para o ar, sendo que a primeira delas foi realizada por Yppê Nakashima. Segundo Joaquim Três Rios, a Esso era o maior anunciante do mundo naquele tempo. A agência era a McCann Erickson.
} 
Globo Cor Especial (fig. 4), foi a mesma coisa. O Boni me ligou e disse: 'Joaquim, cria um filme para um programa infantil. Nós vamos lançar um programa infantil colorido... eu tô te mandando a trilha'. Já era 1972. Peguei e criei, sabe? Fui fazendo lá, as imagens, fui ouvindo (a trilha) e fazendo as imagens. Pôs no ar, ficou no ar quase 20 anos. (informação verbal) ${ }^{41}$

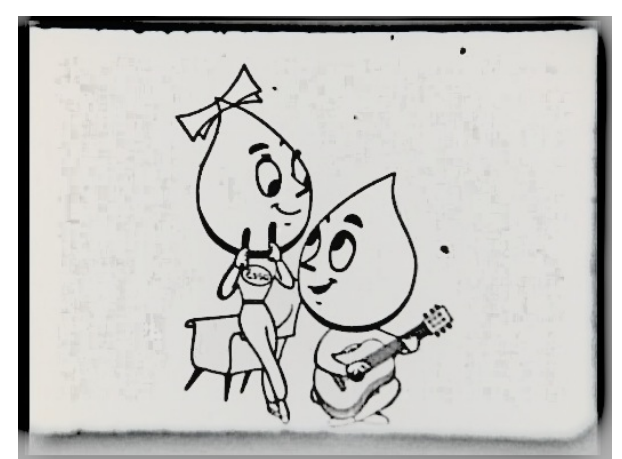

Figura 2- imagem do filme Esso Bossa Nova.

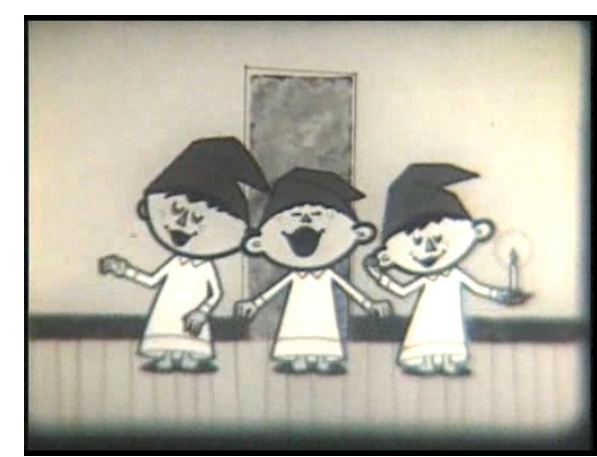

Figura 3 - imagem do filme Parahyba.

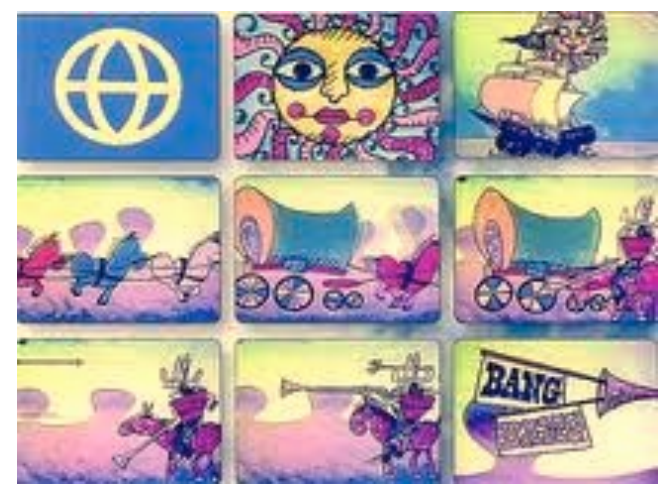

Figura 4 - imagem da abertura do programa Globo Cor Especial.

Conforme a produtora para quem prestava serviço, o estúdio de filmagem variava. Filmes para a Lynx eram filmados na truca da Lynx. Filmes de outras produtoras, como a Magisom, eram feitos com o Joseph Reindl, "o cara mais importante do cinema. Ele fazia trucagens, era um tcheco que tinha vindo pro Brasil naquela leva do pessoal que veio prá Vera Cruz. Ele construiu uma truca na casa dele, na Av. Cupecê, com duas câmaras." (informação

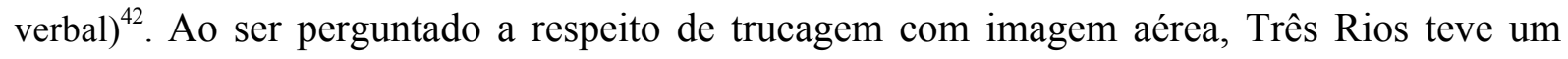
sobressalto: "Que imagem aérea? Era uma câmera de frente prá outra, do tempo de televisão à lenha... Ele batia o fotograma, a máquina não funcionava, ele pegava uma régua e batia assim 'kéh' em algum lugar lá em baixo".

A Léo Pastro, como menciona Três Rios, empregou também Walbercy Ribas, ainda

\footnotetext{
${ }^{41}$ Entrevista concedida por TRÊS RIOS, Joaquim. Entrevista I. [out. 2012] São Paulo. Entrevistador: Maria Luiza Dias de Almeida Marques. 2012. A entrevista na íntegra encontra-se transcrita no Apêndice A desta monografia.

${ }^{42} I d ., 2012$, p. 4.
} 
que por um curto período. Após três anos na Lynx, de 1959 a 1962, e sua passagem pela Leo Pastro, Ribas nunca mais voltou a ser empregado, montando a Start em 1966. A busca por uma linguagem mais vanguardista e o gosto por cinema experimental levaram Ribas a uma pesquisa que aliasse suas preferências artísticas à viabilização do projeto de viver de animação. As animações do Leste Europeu que Ribas assistia no antigo Cine Bijou ${ }^{43}$, foram referências carregadas para toda a sua produção de filmes publicitários. Ribas citou Dusan Vukotic, Jri Trnka, Karel Zemman, filmes da UPA, de George Dunning, e outros que na sua visão realizavam filmes de vanguarda.

Eu assisistia esses filmes e ficava muito animado na época. Aí eu comecei a fazer os primeiros experimentos. Em 1970, 1971, eu fiz um comercial pra Santista, em que eu usei um pouco dessa linguagem; e aí eu estourei com o Barata Rodox, que foi um sucesso aqui e lá fora também, porque eu ganhei o primeiro prêmio da minha vida, que foi no festival de Veneza de publicidade. Aí eu comecei a sentir que eu 'tava me identificando melhor com essas coisas que eram possíveis de serem feitas aqui, lembrando sempre que eu nunca parti prá fazer filme de curta-metragem, essas coisas, porque, curtametragem, nunca teve apoio nenhum. Eu tentei aplicar tudo isso que eu gostava, na publicidade, porque a publicidade, mal ou bem ela te paga e você sugere pras pessoas da agência fazer um trabalho mais de vanguarda. (informação verbal) ${ }^{44}$

O filme a que se refere do inseticida Rodox (fig. 5) é um exemplo de experimentalismo na publicidade, tanto pelo método de realização e como pelo resultado alcançado.

Fizemos tudo ao contrário do método de limpeza de acetato usado naquela época. Para conseguir transmitir a ideia de sujeira da casca da barata, passamos sobre o acetato, sebo de boi. Com isso, ao pintar o desenho com tinta nanquim, a tinta só grudava em alguns lugares do desenho, e como a animação é uma sequência de movimentos, a barata, ao se movimentar, a pintura se movimentava e tremia, passando a ideia de sujeira. [...] O meu primeiro prêmio internacional na minha vida, ganhei fazendo em uma mesa de animação construída a partir de madeiras extraídas de uns caixotes. Nem tinha disco de animação: quando tinha que girar pra acompanhar a curva do desenho, eu tinha que girar a mesa ou girava o corpo. A barata foi o primeiro personagem brasileiro premiado lá fora. (informação verbal) ${ }^{45}$

\footnotetext{
${ }^{43}$ Atual Espaço Unibanco de Cinema, na Rua Augusta, São Paulo, SP.

${ }^{44}$ Entrevista concedida por RIBAS, Walbercy. Entrevista II. [ago. 2013] São Paulo. Entrevistador: Maria Luiza Dias de Almeida Marques. 2013. A entrevista na íntegra encontra-se transcrita no Apêndice B desta monografia. ${ }^{45}$ Id., 2013, p. 21.
} 


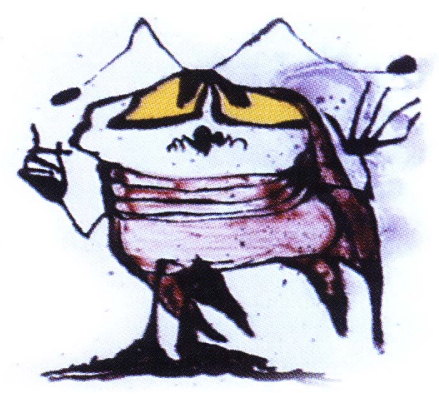

Figura 5 - imagem do filme Rodox.

Em pouco tempo a Start passou a ser identificada como estúdio de propostas visuais mais arrojadas, sendo portanto contratada por clientes que apostavam nesse tipo de comunicação para fixar ou lançar sua marca. Um exemplo disto é o lançamento do indigoblue pela USTOP (fig. 6):

Foi justamente uma revolução, porque até então todo mundo usava 'calça faroeste'; e aí foi a introdução do tecido Indigo-Blue na calça jeans-faroeste. Fez um sucesso incrível, praticamente alavancou a empresa, que é a Alpargatas, que fazia isso aí. Na época, peguei também outros clientes interessantes, que eu consegui alavancar um 'plus' na vida deles, clientes para quem eu fazia coisas mais revolucionárias. (informação verbal) ${ }^{46}$

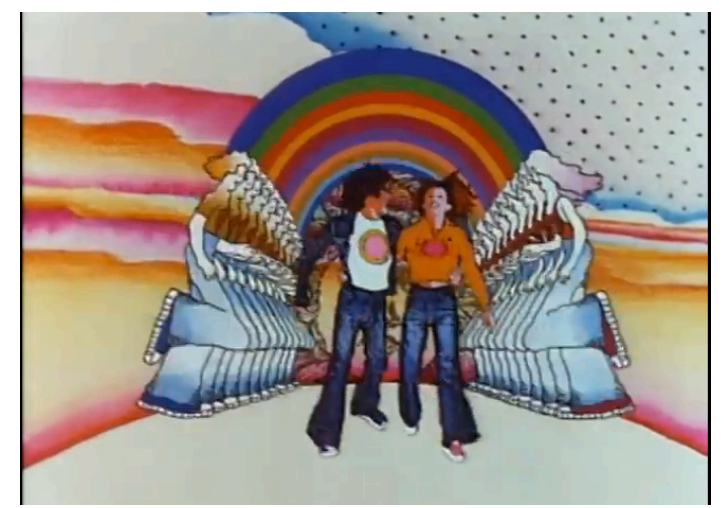

Figura 6 - imagem do filme "Indigo-Blue", para a USTOP.

Na chegada dos anos 70, Três Rios, Messias e Ribas já desfrutavam de um certo status na animação publicitária e concentram know-how suficiente para se manter na liderança do mercado de animação, como observa Messias:

A televisão na década de 1970 explodiu realmente. Os estúdios de animação que faziam trabalhos, digamos, de qualidade, que o mercado exigia, eram muito poucos. Eu me recordo que na época tinha o Walbercy, da Start Filmes, o Guy Lebrun, que depois se transformou em Briquet, tinha o Joaquim Três Rios, e tinha a Lynx Filmes. A Lynx continuou ainda, mas um pouco decadente. Quer dizer, esse era basicamente o mercado inteiro, não

${ }^{46}$ Ibid., 2013, p. 2. 
vou dizer brasileiro, porque o mercado estava todo em São Paulo praticamente, o mercado de $1^{\text {a }}$ qualidade, top. (informação verbal) ${ }^{47}$

$\underline{\text { Tempo de empreendedorismo - montagem e funcionamento dos estúdios }}$

Dividindo o mesmo mercado publicitário, mas guardando particularidades estilísticas, cada um dos entrevistados adentra os anos 70 com perspectivas de ampliação da capacidade produtiva, baseada na contratação de mais profissionais - relacionada à divisão de tarefas - e compra de equipamento. Referimo-nos às mesas de luz, aos table-tops e às máquinas de fotocópia para o acetato.

No caso de Três Rios, a reputação em animação e efeitos ópticos (para filmes comerciais e aberturas de programas de TV), característicos de seu estúdio, aliados a seu contato com José Bonifácio de Oliveira Sobrinho, o Boni, levou-o a realizar muitos trabalhos para a produtora Blimp, fundada em 1968 por Boni, seu irmão Guga, Maurice Capovilla, Walter Carvalho, entre outros. O carro chefe da Blimp era o documentário, mas ela produziu dezenas de programas para a TV Globo e participou da formatação do "padrão Globo" de qualidade. Sua produção mais aclamada foi, a partir de 1973, o programa Globo Repórter.

A prestação de serviços para a Blimp trouxe a Três Rios a necessidade de aprofundamento técnico, temperado com uma certa dose de improviso, ou seja, o drible do nosso atraso tecnológico-industrial através do empirismo e da criatividade, como recorda:

O Reindel importou uma Oxyberry com aereo image, só que ninguém sabia o que era aquela $\mathrm{p} .$. . Ele fazia as trucas dele, a gente não sabia nada. O Boni falou em Vila Sésamo. Então nós vimos que precisávamos se profissionalizar prá trabalhar melhor. $\mathrm{E}$ aí, alguém tinha um disco de animação. O Reindel pediu o disco emprestado, o mecânico chamado Markian fez uma forma desse disco e desse disco começaram a fabricar os discos nacionais. Olha, eu comprei 4, o Daniel Messias comprou também 3 ou 4, o Reindel comprou 4, durante mais de 20 anos ele vendeu os discos de animação. E assim que nós nos profissionalizamos, construímos as nossas caixas de luz, começamos a trabalhar com 3 pinos; a furadeira, também o Reindel conseguiu emprestado de alguém e o Markian copiou; depois, só muito mais tarde eu importei discos de animação, até de campo $18^{48}$, campos maiores. (informação verbal) ${ }^{49}$

Daniel Messias, vivendo o mesmo processo de expansão, complementa:

[...] no caso de uma perfuradora, eu importei uma inglesa ótima, pesadona,

\footnotetext{
${ }^{47}$ Entrevista concedida por MESSIAS, Daniel. Entrevista III. [jan. 2013] São Paulo. Entrevistador: Maria Luiza Dias de Almeida Marques. 2013. A entrevista na íntegra encontra-se transcrita no Apêndice C desta monografia.

${ }^{48}$ O campo é o tamanho do espaço disponível para o desenho na mesa de animação.

${ }^{49}$ Entrevista concedida por TRÊS RIOS, Joaquim. Entrevista I. [out. 2012] São Paulo. Entrevistador: Maria Luiza Dias de Almeida Marques. 2012. A entrevista na íntegra encontra-se transcrita no Apêndice A desta monografia.
} 
ela está perfeita até hoje. E eu importei essa máquina no início da década de 1970. Está em casa ela. É perfeita, nunca precisou de um ajuste, nada disso. E tinha outra, que está até com um amigo, feita por um russo, que tinha uma oficina aqui no Brasil, se chamava Markian, e ele fornecia essas máquinas prá todo mundo. Ele tinha uma pequena siderurgia. Ele foi o único que fabricava alguma coisa assim prá animação, reguinhas de animação, discos, essas coisinhas, ele andou fazendo uma incursão nesse negócio. (informação verbal $)^{50}$

E com os discos nacionais forjados a partir dos importados e comprados do Markian, em 1975, Daniel Messias deixou de trabalhar como freelancer e montou sua produtora, numa grande casa no Pacaembu (mais tarde comprou também a casa vizinha), contratando um animador fixo e duas arte-finalistas, num período que considera ser o boom do comercial de TV. Foi a alternativa encontrada por Messias para dar conta da demanda de trabalhos maiores, para clientes como DPZ, Thompson, McCann.

Joaquim, por sua vez, inicia uma transição para uma fase de pujança em seu estúdio, com a contratação de mais profissionais. Para a Blimp, ele fez aberturas do Globo Cor Especial, Jornal Nacional, Fantástico, animações para o Vila Sésamo (das quais, mais de uma hora se perderam), etc. Joaquim Três Rios percebe a necessidade de encarar seu negócio de maneira mais profissional, com mais funcionários, divisão de trabalho, equipamentos melhores:

A minha primeira mesa de luz, foi o seguinte: quando fizemos o 'Globo-Cor Especial', quando a coisa "pegou no breu" com o Boni [...]. Minha equipe chegou a ter mais de 50 membros no tempo de 'Vila Sésamo'. Normalmente porém, compunha-se de 15 a 20 pessoas.[...] Conforme eu fui progredindo, fiz mais ou menos como o Disney: se o cara ali desenha muito melhor do que eu, por que que eu vou desenhar? Eu criava, ia lá, 'eu quero a coisa assim, assado'; às vezes eu dava um boneco, o animador vinha e: 'olha, Joaquim, e se a gente fizer em vez deste, este?', 'beleza, vamos fazer'. (informação verbal) $^{51}$

A divisão do trabalho, observada no relato de Joaquim, consiste numa condição essencial para a sobrevivência de qualquer estúdio de animação, desde John Randolph Bray, como visto no capítulo I, e foi adotada pelos três entrevistados de maneira semelhante em seus estúdios. Joaquim Três Rios, Walbercy e Daniel Messias, nunca tiveram sócios e concentravam em suas mãos as decisões cruciais de cada projeto: reunião com agência, desenvolvimento do brieffing, orçamento, pré-produção, direção, decupagem e story-board,

\footnotetext{
${ }^{50}$ Entrevista concedida por MESSIAS, Daniel. Entrevista III. [jan. 2013] São Paulo. Entrevistador: Maria Luiza Dias de Almeida Marques. 2013. A entrevista na íntegra encontra-se transcrita no Apêndice C desta monografia. ${ }^{51}$ Entrevista concedida por TRÊS RIOS, Joaquim. Entrevista I. [out. 2012] São Paulo. Entrevistador: Maria Luiza Dias de Almeida Marques. 2012. A entrevista na íntegra encontra-se transcrita no Apêndice A desta monografia.
} 
planejamento de cena, estilo do desenho, direção de arte. A animação propriamente dita, executada nos primeiros tempos pelos próprios empresários, passou a ser delegada a animadores, em geral contratados fixos da casa.

No caso da série de filmes feitos para a Sharp pela Start, a trilha sonora também era escolhida pelo diretor, Walbercy Ribas. Vale comentar que durante cerca de 10 anos, a Start recebeu carta branca do cliente para a criação de filmes que fossem absolutamente inovadores e impactantes do ponto de vista estético. Ribas se trancava em sua sala e trabalhava em segredo no layout desses filmes, buscando as imagens mais surreais, o que rendia filmes revolucionários, os quais só eram apresentados ao cliente quando prontos, ou seja, sem que houvesse aprovação prévia a cada etapa do filme:

[...] a partir da USTOP, eu recebi um convite prá fazer um filme pra SHARP, que foi onde realmente eu achei que foram os 10 melhores momentos da minha vida, foram 10 anos, mais ou menos. As pessoas gostavam demais do que eu fazia, mas, ficavam com o pé atrás. As pessoas achavam que era muito louco, que eu devia consumir uma droga desgraçada, que eu devia ter alguma coisa de budista, mas eu sempre fui uma pessoa extremamente comum [...]. Nós vivíamos no regime militar, e quando eu fiz o filme 'Som Colorido' (fig. 7), eu tinha viajado pro Peru, fui prá Machu Picchu, um lugar muito lindo, místico, então eu trouxe um pouco da essência da coisa peruana, coloquei um mural peruano no fundo da primeira cena, que tem o homem pegando fogo, com cadeado na boca, e lá em Brasília, se sentiram incomodados. [...] O Simonsen 'tava lá no Ministério da Fazenda e mandaram um soldado ficar na frente da televisão prá ver quando ia passar o filme da Sharp; O Simonsen queria ver os filmes também, mas ele não tinha nada a ver com o regime militar. Mas ele queria ver porque ele admirava. (informação verbal) ${ }^{52}$

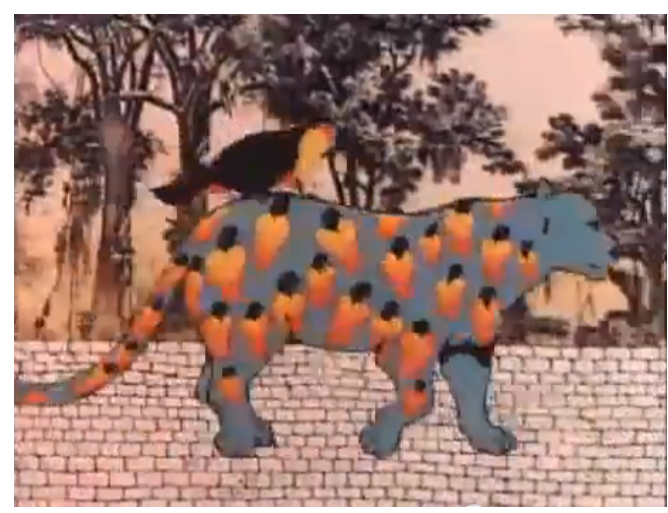

Figura 7 - imagem do filme "Som Colorido", para a Sharp.

A autonomia marcou também parte representativa do trabalho que Três Rios prestou

\footnotetext{
${ }^{52}$ Entrevista concedida por RIBAS, Walbercy. Entrevista II. [ago. 2013] São Paulo. Entrevistador: Maria Luiza Dias de Almeida Marques. 2013. A entrevista na íntegra encontra-se transcrita no Apêndice B desta monografia.
} 
para a Globo, no período de 1968 a 1986, porém, jamais "às cegas" como na série da Sharp. Joaquim tinha liberdade de criação em alguns projetos pela confiança na qualidade do trabalho e na rapidez da entrega, ao que tudo indica. Quando Os Trapalhões foram para a Globo, o estúdio de Três Rios teve dez dias para produzir a vinheta de abertura:

Fazia o story-board, mandava pro Rio, o Boni dizia ok, voltava prá mim e a gente começava a produzir; às vezes atrasava mais ainda porque não tinha trilha, mas aí começava a animação prá ser encaixada, e as coisas acontecem, mas às vezes acontecem também os desastres. Um risco total, às vezes não ficava bom e tinha que fazer outra vez.... Esse 'não existe nada mais antigo' (Globo Cor Especial) eu tenho ele assinado pelo Boni, com a seguinte observação do Guga: 'Boni, imagina isso aqui em cores', o Boni respondeu 'ok, toca'. a Globo me chamava, eu ia lá, dava um logotipo do programa e pedia uma abertura. Vale a pena ver de novo, eu quero uma abertura, eu vinha prá São Paulo fazia o filme. Às vezes nem fazia story-board, fazia o filme direto. 'Era prá ontem'. Eu nunca tive um filme que o Boni dissesse 'olha, isso aí tá uma porcaria, nós não vamos usar', nunca, nunca. Ele confiava na gente. O máximo que acontecia era corrigir aqui e ali [...], também tinha o problema de encaixar no tempo certinho. (informação verbal) $)^{53}$

Além das vinhetas para a TV Globo, havia produção de desenhos animados comerciais, que levavam o estúdio a produzir cinco, seis filmes por mês, com uma média de 40 a 50 funcionários na empresa. No mesmo período, a Start contava com uma média de 35 a 40 pessoas divididas em várias equipes, cada qual responsável por um filme: equipe de animadores (6 ou 7), equipe de intervaladores/cleaners (4 ou 5), equipe de arte finalistas (a quantidade variava conforme os projetos e em geral eram moças). Já Messias, trabalhou "sempre tentando conter a expansão e virar uma mega empresa". Com uma média de 3 filmes ao mês, ele considerava ter uma equipe grande com 17 pessoas.

O equilíbrio entre a concentração de poder e a divisão do trabalho mostrou-se um modo eficaz de garantir ao diretor o controle sobre a produção. Para Messias, cujo gosto particular era pela animação propriamente dita, o trabalho do animador requer concentração e dedicação exclusivas, o que é incompatível com a coordenação geral de cada projeto.

Eu prefiro fazer isso (coordenação) porque eu mantenho o controle overall do filme, a fazer a animação e entregar isso para um outro, um terceiro, o que não tem nenhum sentido: o cara fazer um story-board, e eu fazer a animação. Então, eu passei a sempre fazer essa parte de direção, story-board, planejamento de cena e direção visual também. Isso tudo implica em decisões. Quando você pega um filme, a agência quase sempre não sabe o que fazer. 'Olha, nós temos um roteiro assim, o que você sugere?'

A coordenação geral dos estúdios, sob a batuta de seus donos, incluía desde o

\footnotetext{
${ }^{53}$ Entrevista concedida por TRÊS RIOS, Joaquim. Entrevista I. [out. 2012] São Paulo. Entrevistador: Maria Luiza Dias de Almeida Marques. 2012. A entrevista na íntegra encontra-se transcrita no Apêndice A desta monografia.
} 
relacionamento com as agências e o cálculo do orçamento até a finalização e entrega do filme. A base para o cálculo dos custos de um filme dependia de algumas variáveis e se dava de modo semelhante entre os estúdios pesquisados. Em geral, não se tinha um expert em administração, sendo o proprietário o responsável por esta tarefa. Joaquim Três Rios confessou que orçava os filmes na base do "chutômetro", na tentativa e erro, mas arrematou mencionando que no início, os orçamentos eram feitos conforme uma 'regra' criada por Guy Lebrun, na qual a verba era dividida assim: $1 / 3$ era para o trabalho de criação e animação; $1 / 3$ para a arte final, incluindo material e filmagem; e 1/3 para a produtora, incluindo impostos, etc. Messias concorda com Três Rios a respeito do "chutômetro", um processo intuitivo conforme a complexidade e o prazo do filme:

[...] a minha base era a seguinte: US\$ 1000,00 por segundo, eu acho que os outros também adotavam uma coisa parecida, a gente sabia por experiência que dava uma margenzinha razoável de lucro [...] Hoje é muito pouco, porque o dólar hoje está quase que equiparado. Mas na época era um bom dinheiro. O dólar já esteve bem mais alto. [...] Eu não digo que sempre eu conseguisse orçar US\$1000,00 por segundo. Não tem como dizer qual é o preço fixo de um filme de animação. Se alguém disser isso, está faltando com a verdade, porque, na realidade, a agência impõe. O mercado, antes da agência, o mercado impõe esse preço. O preço é uma imposição do mercado, a famosa lei da oferta e da procura. Se não tiver uma margem de lucro, então você está arriscado a fechar. (informação verbal) ${ }^{54}$

A relação com as agências também interferia no orçamento, pois "havia um fator típico da nossa cultura, o chamado BV", 'Bônus de Veiculação' ${ }^{55}$, que funcionava da seguinte maneira, como explicou Messias:

Você calcula tudo direitnho, e quando apresenta prá agência eles dizem 'você sabe que tem $10 \%$ de BV' - até hoje eu não sei o que é BV. É aquilo que você paga prá trabalhar. Bom, eu não sabia que tinha isso. Eu fiz um orçamento, calculando um valor que jà tinha às vezes sido acertado aprioristicamente, por telefone até 'vai custar $\mathrm{X}$ '. 'OK, me apresenta isso no papel'. Eu coloco no papel e me aparece o BV. Quer dizer, então, eu vou reorçar o trabalho. Isso é muito é muito da nossa cultura, infelizmente, isso acontece em 10 entre 10 orçamentos que me pediam. (informação verbal) ${ }^{56}$

Messias ressalta que um filme sem verba para a margem de lucro, mas suficiente para pagar a equipe e que valesse para compor o repertório, não era descartado. Finalmente, um

\footnotetext{
${ }^{54} I d ., 2013$, p. 6.

${ }^{55} \mathrm{O}$ bônus de veiculação consiste em um assunto polêmico entre anunciantes, agências e veículos de comunicação. Trata-se de uma verba que os veículos de comunicação começaram a pagar às agências como gratificação por tê-los empregado na veiculação de determinada campanha. Não vamos entrar neste mérito, pois, sendo polêmico, há os que o defendem e também os que atacam esta prática. No que se refere às produtoras de filmes publicitários, o BV é uma comissão cobrada pelas agências, em geral 10\% do orçamento do filme, para conceder o trabalho à determinada produtora.

${ }^{56}$ Ibid., 2013, p. 7.
} 
projeto que não desse lucro ou mesmo algum prejuízo poderia ser compensado em outro.

Além de Três Rios, Ribas também usava a regra dos terços:

Eu pegava um filme "x" e fazia o filme em três partes: uma parte pros animadores, outra parte prá administração, e uma parte de lucro prá firma. Especificamente não tava dirigido a quantos funcionários iam fazer o filme ou não; todos tinham que fazer o filme. Então ficava assim: lucro da firma era $1 / 3$, gastos com a firma era $1 / 3$, e $1 / 3$ era pro animador. A base bem socializada. (informação verbal) ${ }^{57}$

Não é de se estranhar que a expressão "base socializada" surja no discurso do animador inspirado em filmes do Leste Europeu.

No período aqui estudado, o da animação analógica, a qualidade e o fluxo de trabalho (workflow), assim como hoje, também eram tarefas imprescindíveis para o sucesso de um projeto. Esta organização estrutural incidia na necessidade ou não de se refazer o filme ou parte dele. $\mathrm{O}$ animatic $^{58}$ e o pencil test ${ }^{59}$ garantiam este monitoramento prévio, mostrando o ritmo e a decupagem, antes da finalização e das cores e efeitos. Realizados em película, eram exclusividade dos estúdios comerciais, onde havia orçamento para tal; no entanto, encontraram-se variações no modus operandi de cada um dos entrevistados. Ribas conta que nunca fizeram animatic na Start: "não era a prática fazer animatic. Era na confiança, viu?". A respeito do pencil test, complementa: "Não existia teste de animação; você flipava e 'ahm, tá bom'. Não dava prá filmar [o teste], até dava. Quando o filme tinha verba a gente fazia." (informação verbal) $^{60}$. Para Joaquim Três Rios, o processo de animatic era chamado LeicaReel e compreendia o "story-board absolutamante detalhado, editado sobre a trilha sonora antecipadamente gravada. À medida [em] que as cenas animadas ficavam prontas, substituíam as cenas 'fixas' do Leika-reel, muitas vezes, primeiro ainda em pencil-test e depois, com as cenas finais." (informação verbal) ${ }^{61}$. Para Messias, era cômodo fazer o pencil test em $35 \mathrm{~mm}$ (P/B), dado que sua produtora contava com truca e moviola: "eu tinha office-boy, era muito fácil dele ir ao laboratório, na Líder, na Revela; eu tinha uma pessoa que cuidava da câmera, filmava os pencil tests; a gente só revelava, via em negativo mesmo. Nos últimos tempos de

\footnotetext{
${ }^{57}$ Entrevista concedida por RIBAS, Walbercy. Entrevista II. [ago. 2013] São Paulo. Entrevistador: Maria Luiza Dias de Almeida Marques. 2013. A entrevista na íntegra encontra-se transcrita no Apêndice B desta monografia. $58 \mathrm{O}$ animatic é um filme que mostra o story-board em sequência, com os diálogos nos tempos corretos.

${ }^{59}$ Pecil test é o processo pelo qual as sequências de desenho animado são filmadas antes dos desenhos serem passados a limpo, a fim de se verificar se a animação está de acordo com o planejado.

${ }^{60} I d ., 2013$, p. 11.

${ }^{61}$ Entrevista concedida por TRÊS RIOS, Joaquim. Entrevista I. [out. 2012] São Paulo. Entrevistador: Maria Luiza Dias de Almeida Marques. 2012. A entrevista na íntegra encontra-se transcrita no Apêndice A desta monografia.
} 
filme, você levava um material hoje e à noite já estava revelado." (informação verbal) ${ }^{62}$.

$\mathrm{Na}$ Start, o pencil test tornou-se prática corrente quando Ribas importou um equipamento de vídeo que gravava quadro a quadro. "Eu fui o primeiro a importar um equipamento de pencil test na América do Sul, em vídeo, a empresa era Lion Lamb.". Ele relembra que seu equipamento ficou retido na alfândega junto com o equipamento que veio para a apresentação de Frank Sinatra, em 1980. "O Frank Sinatra veio, cantou, foi embora e o equipamento [do Sinatra] foi liberado depois de muita luta, depois de um ano.". Durante 3 ou 4 anos, ele conta que utilizou o pencil test em vídeo à exaustão. E completa: "abriu um caminho importante, essa época do vídeo, embora ninguém gostava (sic) de filmar em vídeo, mas ele abriu um espaço interessante prá você chegar próximo à computação gráfica." (informação verbal) ${ }^{63}$. Os desenhos do papel, depois de conferidos, via pencil test, ganhariam finalmente os contornos com os quais eram vistos na TV.

Para dar conta do ritmo de produção, a ferramenta que acelerou o processo produtivo foi a máquina de fotocópia, que aos poucos se impôs como necessidade vital para os estúdios. Para Messias, a Xerox foi uma revolução, pois o "acetato é uma mídia ingrata, difícil de trabalhar". Até então, a transferência do desenho do papel para o acetato - filetagem - era feita manualmente com caneta nanquim e o outro lado da folha do acetato recebia o preenchimento de tinta colorida. O filetista deveria ser muito habilidoso e utilizar uma luva de malha de algodão (com furos nos dedos) para não engordurar o acetato e era comum o animador se desapontar com as perdas sofridas na transferência do papel para o acetato. Messias, em sua pequena equipe inicial, relata que antes de adquirir uma xerox, contava com um filetista virtuose:

\begin{abstract}
No começo, eu fazia animação sozinho. Fazia animação, intervalação, e eu não tinha cleaner, sabe por quê? Porque o meu assistente, o Borghi, era um azougue, ele era espetacular, ele pegava o acetato, colocava sobre o papel, com nankim, pincel seco, ele cleanava direto em cima do acetato. O meu desenho, que era muito rafeado, eu nunca trabalhei "clean", o meu desenho sempre foi rafeado, ele colocava na prancheta, colocava o acetato em cima, com pincel seco e com nankim, ele dava o traço, aquele traço meio... que você vê no frango [da Sadia], na década de 70 [fig. 8], e depois, ele mesmo pintava, quer dizer, eu não tinha uma equipe muito sofisticada nos primórdios. (informação verbal) ${ }^{64}$
\end{abstract}

A Xerox já tinha sido utilizada na Disney na produção de 101 Dálmatas (lançado em

\footnotetext{
${ }^{62}$ Entrevista concedida por MESSIAS, Daniel. Entrevista III. [jan. 2013] São Paulo. Entrevistador: Maria Luiza Dias de Almeida Marques. 2013. A entrevista na íntegra encontra-se transcrita no Apêndice C desta monografia.

${ }^{63}$ Entrevista concedida por RIBAS, Walbercy. Entrevista II. [ago. 2013] São Paulo. Entrevistador: Maria Luiza Dias de Almeida Marques. 2013. A entrevista na íntegra encontra-se transcrita no Apêndice B desta monografia. ${ }^{64}$ Id., 2013, p. 5-6.
} 
1961). Já no Brasil, o primeiro a adquirir uma foi Guy Lebrun, seguido de Walbercy Ribas, Joaquim Três Rios e Daniel Messias. Efeitos com imagem aérea também se beneficiaram dessas máquinas que muitas vezes eram desmontadas e adaptadas conforme a necessidade do projeto, como a Xerox Standard de Joaquim Três Rios.

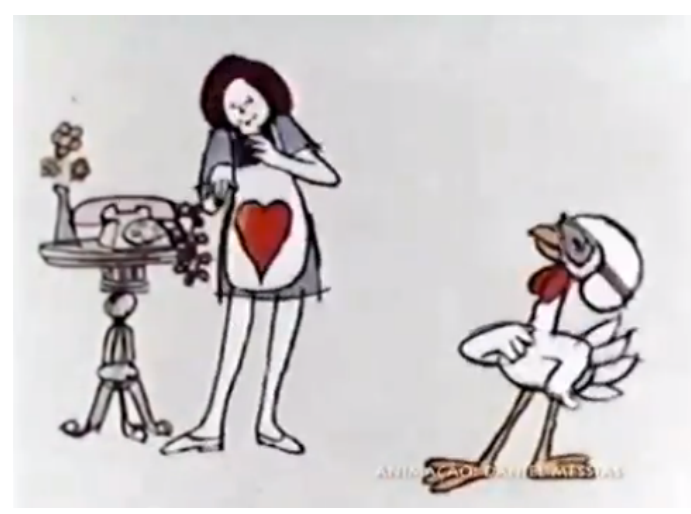

Figura 8 - imagem de filme da série Sadia.

Além da passagem do traço para o acetato, o sistema de fole da Standard permitia a ampliação ou a redução de imagem, necessárias, por exemplo, numa cena de zoom (in ou out) para além do limite alcançado pelo deslocamento mecânico da câmera do table-top. Messias relatou a corrida dos estúdios atrás das Standards da década de 1950, que dormiam encostadas por todo país. Eram máquinas que não fundiam a folha do acetato com o calor e cujo sistema operava como um scanner, com o acetato parado, diferente do funcionamento regular, em que o acetato corria dentro da máquina. Ele, que chegou atrasado na corrida e não conseguiu comprar a sua Standard, descreve a máquina como "uma geringonça enorme" e se regozija da sorte de ter esperado para comprar um modelo mais moderno:

Logo a Xerox começou a fabricar máquinas fantásticas, sabe? E eu comprei uma, e era bem menor do que as outras. E quem tinha aquela standard acabou ficando com um trambolho, não sabia o que fazer com aquilo. (informação verbal) ${ }^{65}$

Ribas relembra a época da aquisição da sua Hank Xerox e explica em linhas gerais seu funcionamento:

Eu vendi uma perua Kombi, uma câmera, várias lentes, mais um refletor, tudo prá comprar essa... vendi todo o meu parque de filmagem ao vivo prá comprar essa máquina. Era uma máquina grande, quase do tamanho desta sala. O problema maior eram umas placas que, imantadas, o pó aderia só no traço do desenho, aí você transferia pro acetato através de eletricidade estática, ozônio que tinha, só preto -e -branco... O pó [toner] que era o segredo; depois começou a aparecer pó azul, pó vermelho, tudo importado.

${ }^{65}$ Ibid., 2013, p. 11. 
Como bem disse Messias, a xerox foi uma revolução na animação. Considerando-se as facilidades que trouxe para criação e a rapidez que proporcionou ao trabalho, seus principais impactos revelaram-se de forma imediata em duas frentes:

1) na estética dos filmes, por ampliar as possibilidades de trucagens e por permitir que o traçado mais espontâneo do animador emergisse no acetato (no filete manual perde-se essa espontaneidade);

2) na gestão dos estúdios, uma vez que grande parte do time de funcionários eram as moças da filetagem. Muitas foram realocadas na empresa - que continuou necessitando delas para pintar acetatos e algumas dedicaram-se a aprender o manuseio da nova máquina (operação e limpeza).

No estúdio de Messias, houve preocupação dos funcionários em relação a possíveis demissões, o que, segundo ele, não ocorreu - não na época da aquisição da xerox. Ele conta que o volume de trabalho aumentou e o pessoal da arte-final passou para a pintura. Ou, seja, a aquisição da xerox não incidiu diretamente no orçamento dos filmes, uma vez que a folha de pagamento é o item mais dispendioso num estúdio de animação.

Além da xerox, outro instrumento de otimização do trabalho foi a truca com disparador automático, de custo muito mais elevado. Joaquim três Rios relata que este equipamento era programável, de modo que se podia escolher o número de fotogramas de uma fusão. Mas os movimentos de câmera ainda eram realizados manualmente, fotograma por fotograma. Este processo requeria uma ficha de animação impecável para garantir a precisão dos movimentos, dos efeitos e o sincronismo com o som.

A finalização dos filmes - edição, sonorização, mixagem - é o momento em que todas as etapas trabalho convergem para uma mídia padrão conforme a tecnologia vigente. Interessa-nos observar aqui o tratamento do material bruto até a sua entrega ao laboratório para a masterização.

Tomando como exemplo um filme com sincronismo labial, efeitos sonoros e trilha musical, em geral, os estúdios recebiam a priori os diálogos gravados numa fita magnética de 1/4' ou em fita cassete comum, que era transcrita para fitas magnéticas perfuradas. Este magnético perfurado era levado à moviola para se decupar as falas em números de fotogramas; segundo Messias, era um processo penoso, pois "não tinha esse esquema do computador, de fone, a gente se trancava na moviola e o som reverberava na firma inteira". $\mathrm{O}$ técnico ou o montador, de posse do story-board, marcava na ficha de animação os tempos de 
cada fala, cada pausa, determinando na ficha o timming do filme.

A animação era feita, pois, nos parâmetros detalhados nesta ficha. Nos estúdios onde se fazia pencil-test em película, o pencil-test era enviado para o estúdio de som para que se compusesse a trilha musical, que era enviada ao estúdio de animação em fita de 1/4' ou em magnético perfurado. Cada estúdio tinha seu técnico responsável pela interface com o laboratório de revelação-masterização. Desta forma, o pacote levado ao laboratório contendo tudo o que apareceria no filme pronto constituía-se do negativo do filme (já colorido e com efeitos) e da trilha mixada com as falas e ruídos (magnético perfurado). No laboratório, o magnético perfurado era transcrito para óptico de som e depois disso, finalmente, imprimia-se a cópia final. Em geral, o copião (o positivo bruto) voltava para o estúdio, onde eram feitas reuniões com o pessoal da agência para a aprovação final do filme antes da entrega.

A gente projetava na moviola, prá ver a qualidade dos efeitos do filme; quando estava $O K$, era o material que a gente apresentava prá agência. Aí tinha aquela reunião, porque a agência não tinha moviola $35 \mathrm{~mm}$. Eles tinham que vir aqui ver o trabalho final, antes de aprovar, porque depois, a etapa final, eram as cópias em $16 \mathrm{~mm}$ [...]. A gente entregava em $16 \mathrm{~mm}$ até a década de 1990, 90 e poucos. Em geral, a gente chamava de reduções, porque era tirado de um negativo $35 \mathrm{~mm}$.... (informação verbal) ${ }^{66}$

A cópia final em $16 \mathrm{~mm}$ ainda viajava para as agências, onde quase sempre havia um projetor $16 \mathrm{~mm}$. Lá, aprovava-se ou não, conforme lembra Messias: "Quase sempre não aprovavam, tinha um problema de um risquinho aqui, outro lá, e se não tivesse, eles inventavam, prá gente tirar uma [cópia] melhor e mandar prá eles. Esse é resumidamente o processo de produção inteiro." (informação verbal) ${ }^{67}$.

O número de cópias de um comercial rendia uma verba extra para o estúdio, além do orçamento. Dessa forma, ocorria que a agência encomendava o filme e depois definia a quantidade de cópias, 40, 50, até 100, em alguns casos, conforme o veículo onde o filme iria passar.

Com variações a cada projeto, conforme a necessidade estética que se impunha - e as respectivas soluções - o modo de produção dos filmes de animação permaneceu estável nos estúdios de publicidade até o final da década de 1980.

É razoável supor que os estúdios aqui pesquisados, que compreendem a linha de frente da animação publicitária paulistana, fossem os que encabeçassem tendências internacionais tanto em termos estilísticos como metodológicos.

\footnotetext{
${ }^{66}$ Entrevista concedida por MESSIAS, Daniel. Entrevista III. [jan. 2013] São Paulo. Entrevistador: Maria Luiza Dias de Almeida Marques. 2013. A entrevista na íntegra encontra-se transcrita no Apêndice C desta monografia. ${ }^{67} I d ., 2013$, p. 10.
} 
Ouve-se falar em computação...

A associação com contemporaneidade é talvez a mais recorrente quando se fala em computação. O uso dos computadores extrapolou a esfera militar já na década de 1950 e nos anos 1960 artistas de vanguarda pesquisaram a criação de gráficos para cinema em busca de um visual inédito. Ao serem perguntados sobre quando e como ouviram falar pela primeira vez em computadores na animação, obtivemos diferentes histórias e reações, as quais relacionamos a seguir, inicialmente com o relato de Joaquim Três Rios, o primeiro a ter notícia da novidade computacional; nota-se que a sua resistência ao novo meio foi determinante no rumo que sua empresa tomou quando dos últimos anos de atividade.

Nos anos 1970, como foi mencionado, Joaquim Três Rios já usufruía de um certo status no meio da animação profissional. Possuía habilidade para entregar o que o cliente pedisse, sendo um dos mais bem equipados para o padrão brasileiro. Suas influências artísticas amadurecem e Bob Abel, criador de comerciais de 7UP e da Benson's and Hedges (cigarros) repletos de luminosos que se movimentam deixando rastros, de longa e multiexposição, passa a ser a referência mais alinhada com a produção atual. Para o padrão brasileiro, Joaquim é um dos mais bem equipados para a realização de efeitos.

Surgiu nos EUA o Bob Able, Robert Able and Associated, com uma magnífica série de filmes gráficos que na verdade eram feitos com recursos totalmente cinematográficos (conhecidos como luminatics), e eu fui buscando assimilar a técnica, tentando criar imagens no mesmo estilo (muitas delas usadas em vinhetas da Rede Globo). Ele tinha um aero image com um condensador de 40". Tinha um dolly com 10, 20 metros. Os filmes dele sempre estouravam o prazo, ele pesquisava. Aí ele foi evoluindo pro computador. Começaram a fazer coisas automatizadas, participou do ET, eles têm outra tecnologia muito na frente da gente. (informação verbal) ${ }^{68}$

Durante a década de 1960, nos EUA e na Europa, muitos artistas estavam pesquisando as possibilidades do uso do computador em audiovisual. Um deles, John Whitney Sr., veio da animação tradicional e desenvolveu animações abstratas com padrões geométricos de luz, cores e sombras, como se observa em seus filmes Catalog, de 1961 e Permutations, de 1966 (fig. 9). John Whitney Sr. desenvolveu, para tanto, um equipamento de computação analógica, resultante da adaptação do mecanismo computadorizado de um canhão antiaéreo. Colaborou com Saul Bass na criação de aberturas de filmes como o já citado Vertigo e foi professor da primeira turma de computação gráfica na UCLA, em 1972.

\footnotetext{
${ }^{68}$ Entrevista concedida por TRÊS RIOS, Joaquim. Entrevista I. [out. 2012] São Paulo. Entrevistador: Maria Luiza Dias de Almeida Marques 2012.. A entrevista na íntegra encontra-se transcrita no Apêndice A desta monografia.
} 


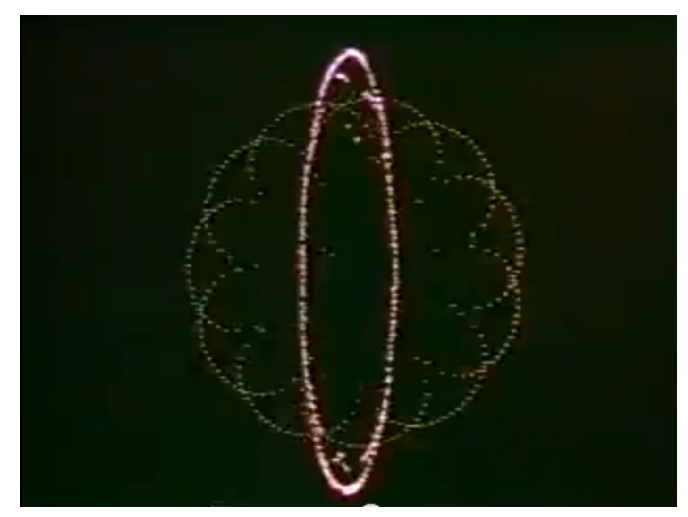

Figura 8 - imagem do filme Permutations.

Em novembro de 1974, Joaquim Três Rios fez uma viagem de 40 dias pelos EUA para visitar estúdios de animação em Nova Yorke, San Francisco e Los Angeles.

Uns 15 dias antes da viagem, a McCann chamou todo mundo prá ver o trabalho de um americano qualquer lá, que tinha o trabalho de computação gráfica. Eram uns logotipos que faziam assim [gesticula, sem jeito]. Eu pensei: 'Isso a gente dá um jeito de fazer aqui'. Era tudo coisa ruim, uma qualidade ruim. 'Isso aí não vai dar certo'. Tanto é, que nós fomos pros EUA, fomos visitar uma porção de estúdios e eu não fui ver o computador. Não acreditei. Cheguei ir a alguns lugares, mas eu não vi detalhe de coisa nenhuma. Tinha umas salas super geladas com uns armários encostados na parede com uns discos deste tamanho, com umas fitas enormes, aquilo corria prá frente prá trás, aquilo era o computador. Umas máquinas enormes. Prá começar, eu não tinha dinheiro nem prá comprar um carretel daqueles, quanto mais uma máquina destas. (informação verbal) ${ }^{69}$

A partir do relato de Joaquim, e assistindo-se aos filmes de Whitney Sr. da virada dos anos 1960 para os 1970, é possível inferir que a referência à "má qualidade" dos trabalhos em computação a que ele se refere deva-se ao fato de ser um trabalho muito distante daquele realizado por Joaquim em desenho animado 2D. Num contexto em que a cinematografia de Walt Disney ainda reinava como linguagem padrão de excelência em animação era possível que a nova linguagem, em desenvolvimento, trazida pela tecnologia computacional, soasse algo sem acabamento, desprovido de "arte".

$\mathrm{Na}$ perspectiva de Joaquim, o computador não seria capaz produzir imagens com a qualidade, as nuances que as mãos humanas faziam. Contudo, sabia que a computação poderia facilitar o penoso trabalho das múltiplas exposições com movimentos de câmera.

Em 1970 a gente já sabia, o Bob Abel já estava usando o computador. Mas Bob Able, na verdade, usava o computador de outro jeito: ele tinha um aero image onde ele bolou aquelas loucuras, e o aero image usava a matemática do computador. Como as máquinas que o Reindel comprou em 1972, as Newson and Order, que o computador fazia o cálculo do movimento... só que a gente não sabia usar aquilo. Só usava o zoom e a fusão. (informação

${ }^{69} I d ., 2012$, p. 8. 
verbal $)^{70}$

O visual neon, dinâmico e plural dos filmes de Bob Abel (fig. 10) coincide com uma noção de modernidade característica daquela época.

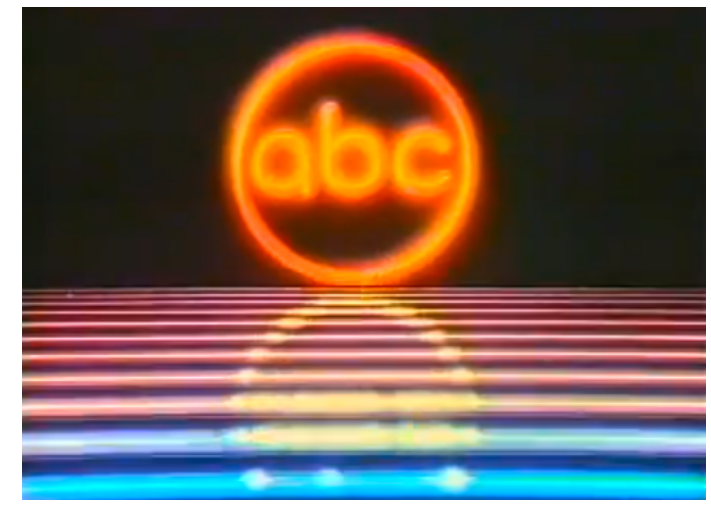

Figura 10 - imagem de abertura de programa feita pela Bob Abel \& Associated.

A solução encontrada por Joaquim para produzir efeitos semelhantes e para simular imagens tridimensionais consistiu no uso da truca com centenas de fotolitos e múltipla exposição, num processo integralmente mecânico-óptico-químico que exigia muitos cálculos e uma ficha de animação perfeita. Para movimentos curvos, usava-se o pantógrafo.

[no letreiro do] Fantástico: primeiro fizemos o letreiro Fantástico, pusemos no table top e filmamos o zoom com pantógrafo [...] fazendo o movimento curvilíneo, filmado em alto contraste. Pegava esse alto contraste jogava isso no aereo image, com filtro de cor, e aí então o letreiro vinha vindo até primeiro plano. Aí voltava o filme. O rastro é cor. O rastro, vc pulava sei lá 10, 20 posições de fade, e começava, em vez de começar na posição 1 de fade, já começava na 20. Aí, da 21 em diante, ia fazendo fade, fotograma por fotograma, até desfazer aquele rastro. E isso, graças a Deus, foi feito lá, lá você tinha o automático. [...] O Hans [Donner] me chamou e disse que a Rede Brasil Sul ia mudar de logotipo. Ia passar prá esse tipo tri-dimensional. Ele precisava do filme. Vim prá São Paulo, mandei fazer o mocap do logotipo, montamos numa traquitana e fotografamos virando o logotipo do jeito que eles queriam. E cada uma dessas fotografias, você tem relevo, sombra, etc., então, o mockup já era pintado como logotipo, fotografia a cores. É o 3 D na mão. Nunca fiz nada com computador, mas fazia tudo 'com-puta-dor'. Tudo sofrido. Tinha que inventar, resolver e fazer. (informação verbal) ${ }^{71}$

A entrada de Hans Donner representou um declínio gradual da volumosa produção de Joaquim junto à TV Globo. A emissora passou a investir em Computação Gráfica através de uma parceria com a PDI - Pacific Data Images - em São Francisco, nos EUA. Inicialmente

\footnotetext{
${ }^{70}$ Ibid., 2012, p. 8.
}

${ }^{71}$ Ibidem. 
produziam as animações lá. Depois, abriu-se um núcleo de computação no Brasil, como será visto no capítulo seguinte com mais detalhes na entrevista com Alceu Batista, da Vetor Zero.

O fechamento do estúdio de Joaquim resultou da convergência de vários fatores: a diminuição do volume de trabalhos para Globo; a manutenção do modo de produção analógico; e a política econômica do governo Fernando Collor.

Mesmo sem a demanda da TV Globo, Joaquim geria um estúdio com equipe que variava de 15 a 20 funcionários até março 1990, época em que se produziam de dois a quatro filmes por mês. À época, a economia do país estava ameaçada pela hiperinflação, o que levou o governo de Collor a impor medidas desastrosas, como o congelamento dos preços e o confisco, como foi chamado o bloqueio por 18 meses de todos os depósitos das contas correntes, das cadernetas de poupança e do overnight (modalidade em que o investidor aplicava no fim do dia e recebia os juros no dia seguinte) acima de 50 mil cruzados novos. $\mathrm{O}$ governo prometeu corrigir o dinheiro pela inflação da época, mas na prática apenas metade dos recursos foi devolvida, situação que Ribas comenta:

[...] até 1990, quando apareceu o vídeo prá animação - o vídeo já existia prá cinema. Você filmar em vídeo era tido como um deboche, filmar em vídeo era porcaria; só que na hora que o Collor confiscou tudo, aí veio a hora da miséria: todo mundo começou a fazer coisinhas em vídeo, porque não tinha mais dinheiro, não tinha verba. Quem pagava US\$100.000,00 prá fazer o filme, passou a só ter US\$ $10.000,00$ prá fazer as coisas. A televisão precisava de filme, o patrocinador precisava fazer filme, aí começaram a surgir as empresas de vídeo, e nós, consequentemente começamos a telecinar. (informação verbal) $^{72}$

Ribas também destaca o intervencionismo de Collor como um golpe na ordem estabelecida:

Uma das coisas que me fez mudar radicalmente aqui dentro foi o Collor, o confisco de dinheiro. Nessa época, eu tive que mudar, por quê? Porque acabou o dinheiro. Eu tinha 30 pessoas aqui dentro nessa época, mandei 15 embora na hora. "não tem mais o que fazer, gente. Não tem mais trabalho, não tem mais nada.". Isso foi bem violento. A entrada do Collor foi um outro divisor de águas na propaganda. Enfraqueceu muita gente, muita gente morreu de enfarto, derrame. Muita gente perdeu tudo que tinha. Um amigo meu, um grande fotógrafo de publicidade, o Kato japonês, tinha vendido a casa prá comprar um apartamento. Nesse ínterim, ficou sem casa e sem apartamento. Foi um confisco comunista, uma piração total. (informação verbal $)^{73}$

No estúdio de Messias não havia dinheiro acumulado: tudo que entrava era rapidamente

\footnotetext{
${ }^{72}$ Entrevista concedida por RIBAS, Walbercy. Entrevista II. [ago. 2013] São Paulo. Entrevistador: Maria Luiza Dias de Almeida Marques. 2013. A entrevista na íntegra encontra-se transcrita no Apêndice B desta monografia. ${ }^{73} I d ., 2013$, p. 17.
} 
direcionado para pagar os funcionários, portanto, relata, não sofreu impacto negativo. Transmutando o clima negativo da época, Messias fez o filme Dinda's (fig. 11), adaptado das crônicas jornalísticas do clã Collor de Mello e inspirado no estilo gráfico do animador americano Bill Plimpton. Recebeu por ele o prêmio no Festival Internacional de Cinema de Havana.

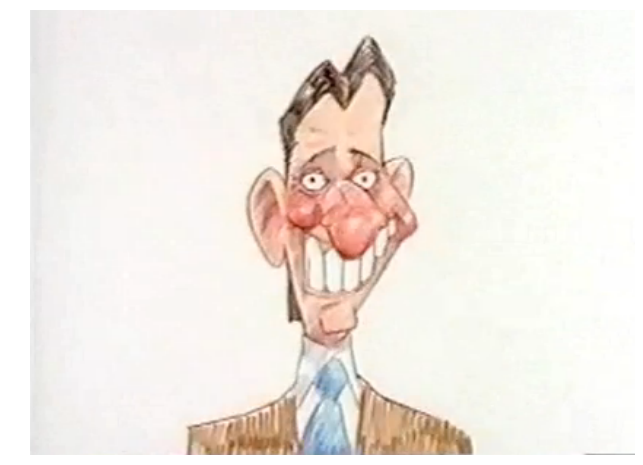

Figura 11 - imagem do curta-metragem Dinda's.

Com as medidas do pacote econômico, em muitos estúdios os trabalhos em andamento e os orçamentos futuros foram cancelados ou reduzidos. O contador de Joaquim sugeriu demitir a equipe e prosseguir sozinho. Ao entregar a casa onde o estúdio funcionava, Joaquim rasgou toneladas de papel e acetato. Nessa ocasião, um jovem estudioso de animação, Gil Caserta, com conhecimentos em computação procura Joaquim e propõe: "eu tenho um projeto no SENAC; semana que vem vão inaugurar uma sala de computadores, e eu queria que você fosse prá lá prá gente fazer animação".

Estavam começando a surgir as placas gráficas e o SENAC estava equipado com ilhas de PCs, Macs e Amiga. Os Amiga mais voltados para vídeo, os Mac para editoração de imagem e os PCs para modelagem e animação 3D. Os cursos faziam o percurso da animação tradicional - no qual participou Joaquim - à animação computadorizada.

Desde então, Joaquim vem ministrando oficinas de animação pelo estado de São Paulo. 


\section{Capítulo 4 - A chegada da nova ferramenta - o início da transição irreversível}

A proposta de tecer o panorama da introdução da tecnologia digital na animação publicitária paulistana a partir das entrevistas coletadas segue, de maneira geral, o fio condutor da cronologia. Como algumas datas não foram lembradas com precisão pelos entrevistados, em alguns momentos saltaremos para frente ou para trás, um pouco devido às datas de aquisição de máquinas, mas sobretudo pelas afinidades temáticas. De todo modo, o tema central estudado surgiu envolto em alguns aspectos relevantes em relação ao que a computação proporciona:

1) aspecto prático: facilitar tarefas repetitivas com rapidez e perfeição;

2) aspecto estético: possibilitar efeitos, modelagem de formas e movimentos em ambiente tridimensional; interferir em imagens captadas "ao vivo"; simular a realidade, introduzir elementos tridimensionais realistas nessas imagens; mesclar técnicas.

3) aspecto funcional: minimizar as perdas de qualidade no fluxo do trabalho;

4) aspecto econômico: baratear custos e democratizar a animação (embora no início o custo fosse alto).

Considerando esses aspectos, foi possível identificar duas categorias de atitudes que emergiram da coleta de dados, referentes aos modos de percepção das possibilidades criadas pela computação e da respectiva adesão às novas técnicas. A primeira categoria é representada por Daniel Messias e Walbercy Ribas, com centenas de filmes consagrados na bagagem; a segunda, por Guto Carvalho e Alceu Baptista, estreando com a tecnologia e o ecletismo.

\section{A recepção da tecnologia}

Na segunda metade dos anos 1980, o custo de um computador com interface gráfica direcionada ao trabalho com vídeo/animação ainda era privilégio de grandes empresas, como canais de TV e finalizadoras de filmes publicitários. A Política Nacional da Informática, no intuito de desenvolver a indústria de informática no Brasil, sancionou a Lei da Reserva de Mercado em $1984^{74}$ (fig. 1), que reservava a fabricantes de capital nacional o direito de produzir e vender bens de informática. Vigente até 1992, essa lei dividiu opiniões; aqueles que a defendem alegam que a lei ajudou a formar profissionais de alto nível nas inúmeras empresas que proliferaram naquele período; seus detratores atribuem a ela o atraso 
tecnológico do país e sua ineficácia em propiciar uma indústria de fôlego para competir com as empresas internacionais, o que causou a falência de quase todas quando se abriu o mercado, oficialmente em 1992.

\section{FOLHADES. PAULO $\quad$ informática $\quad$ Quarta-feira, 4 de setembro de 19916 6.5 \\ Macintosh pode entrar legalmente no país \\ O governo autoriza a compra para casos onde os equipamentos são comprovadamente imprescindíveis}
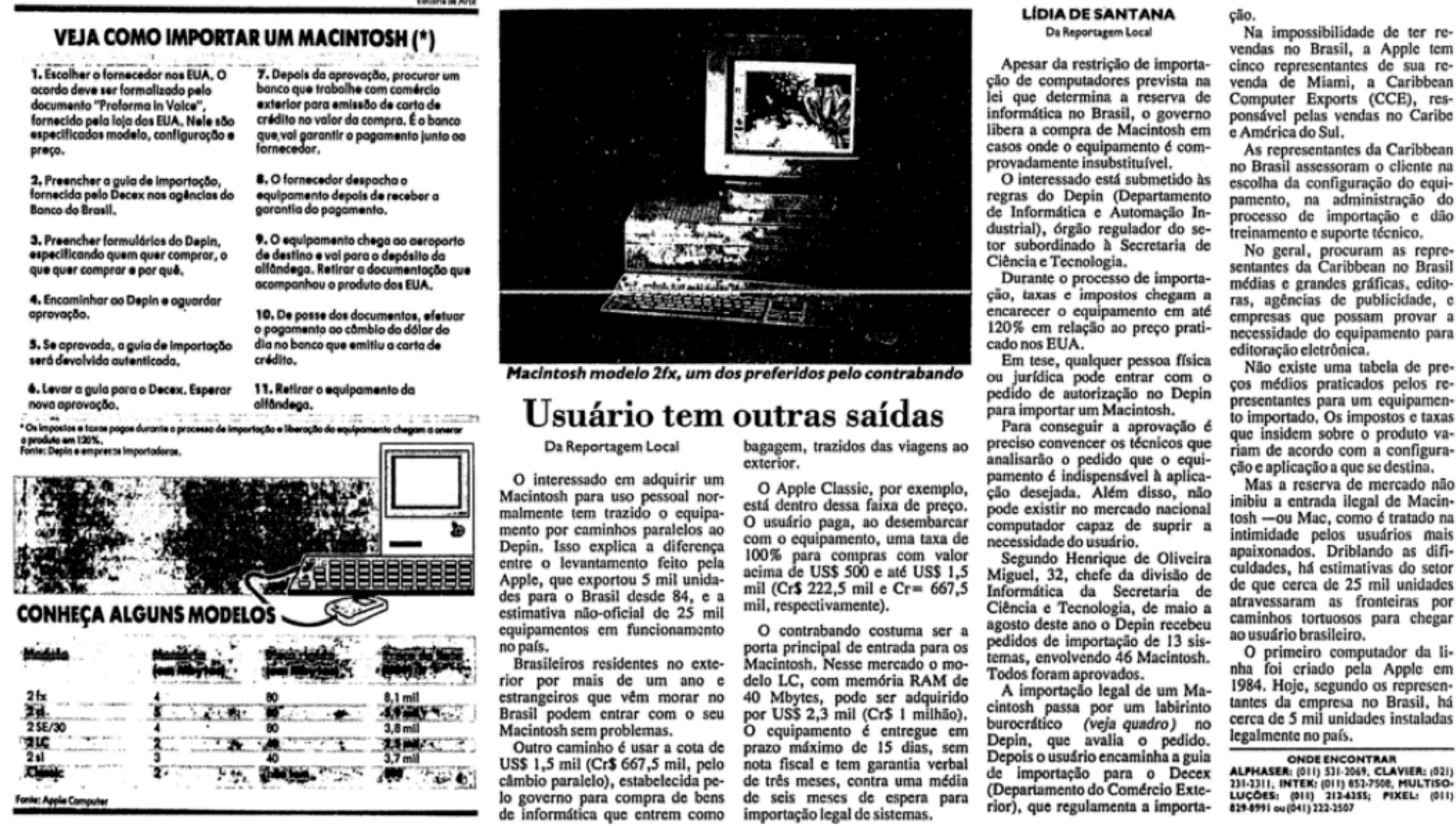
vendas no Brasil, a Apple tem
cinco representantes de sua re-
venda de Miami, a Caribbean Computer Exports (CCE), res.
ponsisvel pelas vendas no Caribe As representantes da Caribbean
no Brasil assessoram o cliente na no Brasil assessoram o cliente nai
escollha da configuraçao do equi-
pamento, na administraçẫo do pamento, na administraçăo do
processo de importaçio e daio
treinamento e suporte técnico, No geral, procuram as repre.
sentantes da Caribbean no Brasil mélias e errandes grafficas, edito-
ras, agencias de publicidade, e ras, agencias de publicidade,
empresas que possam provar a
necessidade do equipamento para Em tese, qualquer pessoa física
ou jurldica pode entrar com editoraçăo cletrónica,
Năo existe una tabela de pre-
cos médios praticados pelos re.

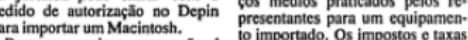
para importar um Macintosh.
Para conseguir a aprovaçăo e $\quad$ to importado. Os impostos e taxas
que insidem sobre o produto val-

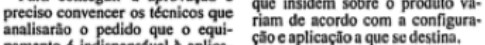

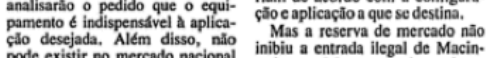
pode existir no mercado nacional
computador capaz de suprir a
necessidade do usuário. Mas a reserva de mercado nẵo
inibiu a entrana ilegal de Macin-
losh - ou Mac, como of tratado na necessidade do usuário.
Segundo Henrique de Oliveira appaixonados. Driblando as difi-
Miguel, 32, chefe da divisalo de culdades, ha hestimativas doo setor
de que cerca de 25 mil unidades Informática da Secretaria de agosto deste ano o Depin recebeu caminhos lortuosos para chegar pedidos de importacio de 13 sis-
temas, envolvendo 46 Macintosh.
Todos forimeiro computador da li-
nha foi criado pela Apple em A importacla legal de um Ma- 1984. Hoje, segundo os represen-
tantes da empresa no Brasil, ha cintosh passa por um labirinto
burocratico (veja quadro) no

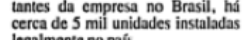
Depois o usuśrio encaminha a guia
de importaçlo para o Decex

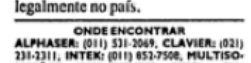
lo governo para compra de bens de seis meses de espera

Figura 1 - recorte do caderno Informática da Folha de São Paulo, que descreve a burocracia para se importar um computador Apple legalmente e explica que o contrabando costuma ser a principal porta de entrada para os Macintosh.

$\mathrm{Na}$ prática, o consumidor final forçosamente adquiria um equipamento inferior e mais caro ou optava por vias alternativas. Alceu Baptista $(2013$, p. 8) lembra o período:

O único jeito de chegar equipamento aqui era por contrabando. Era tudo fechado, nem hospital podia ter coisa digital, não podia ter imagem de tomografia; carro não podia ter injeção eletrônica; não podia entrar nada digital no Brasil, na época havia reserva de mercado para aquelas empresas que ficavam mamando, e atrasou país em 30 anos, até hoje a gente tá atrasado por conta disso. (informação verbal) ${ }^{75}$

Ele continua com uma notável ironia:

[...] pessoal em geral que faz contrabando é muito honesto, porque eles dependem do boca a boca, alguns chegavam até a reembolsar caso a mercadoria fosse apreendida, para não transferir o prejuízo para o cliente. (informação verbal) $^{76}$

\footnotetext{
${ }^{75}$ Entrevista concedida por BAPTISTA, Alceu. Entrevista V. [out. 2013] São Paulo. Entrevistador: Maria Luiza Dias de Almeida Marques. 2013. A entrevista na íntegra encontra-se transcrita no Apêndice E desta monografia. ${ }^{76}$ Id. 2013, p. 8.
} 
Guto Carvalho (2013, p. 10) reforça:

[...] ah, sim, tinha um muambeiro oficial, com certeza. Não havia nenhuma produtora que sobrevivesse sem o seu executivo de fronteira. (informação verbal $)^{77}$

Ao mesmo tempo, trata-se de um período em que o vídeo ganha força como expressão e como mídia, trazendo possibilidades criativas que traziam um certo frescor para a produção padronizada da TV e da publicidade. Com decorrer dos anos, entretanto, o vídeo conjugado com a computação convergiam para uma relativa democratização na produção das animações devido à facilidade e ao barateamento que propiciam, o que atestam os discursos analisados nesta pesquisa. Na percepção de Walbercy Ribas (2013, p. 10), a ascensão do vídeo foi um divisor de águas:

Nós filmávamos em $35 \mathrm{~mm}$ e não fazíamos mais a redução pra $16 \mathrm{~mm}$; morreu a cópia $16 \mathrm{~mm}$ e começou a entrar o vídeo. Fazíamos o telecine do $35 \mathrm{~mm}$ num bureau de vídeo lá na moóca, que depois acabou fechando... O processo de laboratório começou a acabar. Era muito mais fácil você transferir e entregar a cópia de vídeo em U-MATIC. Depois, então, veio a fita beta, que era uma qualidade melhor. (informação verbal) ${ }^{78}$

O bureau a que Walbercy se refere vem a ser a New Vision ${ }^{79}$, uma das grandes empresas que fazia a transposição entre o cinema e o vídeo, uma das primeiras finalizadoras que se preocupou em fazer com precisão e acuidade a transcrição de toda produção publicitária da película para o vídeo. Contavam com um telecine e faziam um trabalho inédito de correção de cor. Guto Carvalho, que em 1991 montou a Trattoria di Frame com Guilherme Ramalho, que era finalizador na New Vision:

[...] a gente teve contato com todo o cinema publicitário brasileiro, com os grandes fotógrafos, os grandes produtores, os grandes picaretas; todo o universo da publicidade brasileira passava, mais cedo ou mais tarde, pelas salas da New Vision. Era uma empresa com um padrão técnico muito rigoroso. A gente teve a oportunidade de participar da digitalização da produção da New Vision, da escolha da plataforma digital que foi instalada na New Vision prá sair da finalização em Betacam. A gente partiu pra finalização totalmente digital numa workstation que custava US $\$ 400,000.00$, na época. As estações de trabalho digitais eram da ordem de US $\$ 700,000.00$, US\$ 400,000.00, eram muito caras. (informação verbal) ${ }^{80}$

\footnotetext{
${ }^{77}$ Entrevista concedida por CARVALHO, Guto. Entrevista IV. [set. 2013] São Paulo. Entrevistador: Maria Luiza Dias de Almeida Marques. 2013. A entrevista na íntegra encontra-se transcrita no Apêndice D desta monografia.

${ }^{78}$ Entrevista concedida por RIBAS, Walbercy. Entrevista II. [ago. 2013] São Paulo. Entrevistador: Maria Luiza Dias de Almeida Marques. 2013. A entrevista na íntegra encontra-se transcrita no Apêndice B desta monografia.

${ }^{79}$ Localizada no Bairro da Mooca.

${ }^{80}$ Entrevista concedida por CARVALHO, Guto. Entrevista IV. [set. 2013] São Paulo. Entrevistador: Maria Luiza Dias de Almeida Marques. 2013. A entrevista na íntegra encontra-se transcrita no Apêndice D desta monografia.
} 
A trajetória profissional de Guto Carvalho em direção ao audiovisual foi marcada pela pesquisa em diferentes esferas disciplinares, combinando as vertentes científica, artística e humanística. Seu interesse pelo cinema de animação é mais relacionado a uma pesquisa em torno do movimento do que à narrativa. Trata-se de uma tentativa observar a natureza e como se dão os fluxos do tempo, utilizando a lente da animação. Iniciou os estudos na física da UNICAMP, onde durante quatro anos envolveu-se com pesquisa científica; sua vertente artística desenvolveu-se em boa parte no estudo de dança, na Universidade da Bahia; finalmente, o lado humanístico de sua formação deve-se ao curso de pedagogia, na Universidade de Brasília e na pós-graduação em TV educativa. Portanto, quando Guto Carvalho chegou à produção de cinema publicitário, e à New Vision, sua bagagem era eclética.

O alcance da computação como instrumento de criação revelava-se a cada novo filme, mas era certo que apostar nela significava renunciar a um modo de produção estruturado durante décadas. Não é difícil imaginar que uma geração que se fez no desenho animado clássico encontre na computação a solução para muitas das adversidades práticas intrínsecas à animação. Pelo menos no princípio, nas produtoras tradicionais, vislumbrava-se uma nova maneira de se fazer as mesmas coisas. Mas a revolução trazida pelos computadores implicou muito mais do que a substituição de métodos de trabalho, ela trouxe uma mudança no paradigma da animação. A própria palavra animação ganhou flexibilidade, assumiu novos contornos. Em seu artigo What is animation and who needs to know?, Philip Kelly Denslow ${ }^{81}$ reflete que o desenvolvimento das tecnologias de produção/consumo incide na definição de animação, e questiona seus limites:

Realidade virtual é uma forma de animação? Simulação de vida em ambiente digital pode ser qualificada como animação? Técnicas digitais de pósprodução que permitam compor cenas ao vivo com personagens duplicados digitalmente de maneira não perceptível podem ser consideradas animação? Todas as definições de animação precisam ser repensadas no contexto da tecnologia em desenvolvimento. [...]

A habilidade de editar, combinar e reproduzir animação ou live action de maneira não perceptível, não apenas confunde qualquer distinção entre estas técnicas, como também modifica o valor que se agrega ao trabalho. (DENSLOW, 1995, p. 1-3) (tradução nossa)

Assim sendo, o termo animação passa a abarcar inúmeras possibilidades extras, incluindo técnicas de composição e de mixagem de linguagens que esfumaçam a fronteira entre 3D, fotografia digital e live action.

\footnotetext{
${ }^{81}$ Philip Kelly Denslow, "What is Animation and Who Needs to Know?", in ed. Pilling, Reader in animation Studies, p. 2-3
} 
Diferentemente da reação de Joaquim Três Rios, Walbercy e Daniel Messias saudaram os computadores com otimismo. Com carreiras talhadas na animação tradicional $2 \mathrm{D}$, na rotina do papel, lápis, acetato, truca, reconheceram rapidamente que o computador seria a ferramenta que os libertaria de muitos inconvenientes da rotina de estúdio e também criativamente. Foi consenso entre todos os entrevistados que o computador depende de um bom animador, não podendo substituir a mão de obra criativa, apenas, a mecânica. O desejo de criar uma cena em animação com movimento de câmera foi um dos fatores que levou Walbercy a considerar investir em equipamentos de computação.

\begin{abstract}
A angústia da gente como animador, como diretor, era ver movimento de câmera em animação; era tudo parado, se quisesse movimento de câmera tinha que fazer tudo na unha, tudo na mão, quadro-por-quadro, um por um, desenho por desenho, objetos, cadeirinha, tudo tinha que ser feito na mão; aí 'cê tem que fazer teste, girava e dava tranco, voltava e corrigia; faz com fotografia depois passa pro desenho, aí vc passava a limpo o desenho e estava ruim, corrige de novo. Era um desafio prá dar o melhor de si. O que eu acho fantástico nesse trajeto é que a gente tentava ir além do que as máquinas proporcionavam em animação, porque a máquina de filmar desenho animado era fixa numa torre, sobe e desce... (informação verbal) ${ }^{82}$
\end{abstract}

Walbercy tomou conhecimento da computação nas artes gráficas e no audiovisual através de matérias em revistas importadas que traziam experiências com plotter, uma espécie de impressora capaz de passar para o papel um objeto tridimensional desenhado com o software Auto-Cad ${ }^{83}$. Com esse equipamento, podia-se desenhar um ambiente com objetos de cena no software e se determinar um movimento de câmera em um determinado número de fotogramas. Cada fotograma de uma cena com movimento era impresso e redesenhado, retrabalhado, inserindo-se a figura de um personagem animado ${ }^{84}$, por exemplo. Este uso do plotter vigorou por pouco tempo. Menos de um ano depois de sua chegada ao Brasil, já havia no mercado o computador com saída para vídeo. Walbercy Ribas comenta a respeito de seu concorrente, em tom ligeiramente malicioso: "O Daniel Messias usou o plotter; eu não cheguei a usar. [...] Nós fazíamos a mesma coisa com maquete." (informação verbal) ${ }^{85}$. Walbercy refere-se ao desenho de observação de um cenário - a maquete - em movimento quadro a quadro.

\footnotetext{
${ }^{82}$ Entrevista concedida por RIBAS, Walbercy. Entrevista II. [ago. 2013] São Paulo. Entrevistador: Maria Luiza Dias de Almeida Marques. 2013. A entrevista na íntegra encontra-se transcrita no Apêndice B desta monografia.

${ }^{83} \mathrm{O}$ Autocad $(\mathrm{CAD}=$ computer aided design $)$ é uma ferramenta utilizada para o desenho de diversos produtos em inúmeras áreas, como a indústria automobilística, engenharia, construção civil, arquitetura. Foi criado pela Autodesk em 1982.

${ }^{84} \mathrm{O}$ processo é detalhado no making-of do filme "The Great Mouse Detective", lançado em 1986, em $<\mathrm{https} / / / \mathrm{www} . y o u t u b e . c o m / w a t c h ? \mathrm{v}=\mathrm{jUiY}$ yimp4jM>. (acessado em: 03/03/2014).

${ }^{85}$ Id, 2013, p. 12.
} 
A sofisticação trazida pela tecnologia digital passou por várias etapas ao longo dos anos, desde a chegada dos primeiros equipamentos e a cada novidade que surgia no mercado. Em relação aos processos de finalização e masterização dos filmes, por exemplo, Walbercy conta que:

Nós passamos a melhorar a qualidade fazendo o seguinte: levando o som original, a fita gravada no estúdio - a fitinha $1 / 4$, rolinho, não existia fita DAT. O cara na hora copiava. Aí, vc levava o negativo original, não fazia mais cópia: telecinava o negativo. Transformava o negativo em positivo, assistia um tipo de máster. Assim, você copiava o negativo e jogava prá máquina. Depois você tinha que ir na ilha, o que encarecia de um lado, mas compensava pela qualidade, pela limpeza do trabalho; as cópias já não tinham risco, já não tinham verde, você passou a ter um controle de qualidade melhor. Lá na ilha de edição você juntava o som com a imagem, aí, você punha claquete. (informação verbal). ${ }^{86}$

O processo descrito acima ainda incluía a contratação do serviço de uma finalizadora naquela época, a New Vision - que possuía grandes computadores, os mainframes. Até aí, ainda se trabalhava com acetato, nankim, aerógrafo, truca.

A percepção que se tinha de um modo geral a respeito da computação era positiva. $O$ cenário otimista foi muito bem traduzido pelas palavras de Denslow (1995, p. 3) , que destacou três consequências diretas da evolução tecnológica: "1 - possibilidade de investir em pequena escala com vistas a alcançar mercado de larga escala através de redes de telecomunicações; 2 - novas possibilidades estéticas replicando elementos reais e combinando-os com material criado no reino digital; 3 - popularização da visão pessoal do animador.".

O animador independente Arnaldo Galvão que na década de 1980 fez parte de uma nova geração junto com Flávio del Carlo, Céu d'Elia, entre outros - identificados com animação tradicional 2D -, faz coro com os animadores mais experientes:

Eu não conheci ninguém contra os computadores. Nem por medo nem por purismo. Produzir animação antes deles era muito caro, acetatos, película, table tops, laboratórios...não podia ficar mais complicado. Os primeiros softs eram bens toscos, mas logo no começo dos anos 90 foram lançados alguns, como o AXA, que reproduziam tudo o que se fazia num estúdio. (informação pessoal). ${ }^{87}$

Tomando como exemplo o uso do acetato, ficam evidentes as desvantagens do processo analógico: o acetato era importado (dos EUA, o Cartooncolour ${ }^{88}$, ou da Inglaterra, o

\footnotetext{
${ }^{86}$ Ibid., 2013, p. 10.

${ }^{87}$ Entrevista concedida via e-mail em 29/03/2014.

${ }^{88}$ Essas empresas ainda hoje fabricam e vendem acetatos para aninação. O pacote contendo 100 folhas de acetato custa atualmente U\$ 82,00 (No anúncio do Cartooncolour, consta assim: Very high quality, transparent, clear
} 
Chromacolour) a um custo de U\$1,00/folha. Assim, 1) cada folha tinha que ser perfurada, não podia ser reutilizada (perdia-se a transparência na lavagem); 2) a tinta tinha que ser a importada também, pois era a que melhor aderia; 3) havia a limitação do número de camadas sobrepostas, no máximo 6, para que houvesse menos alteração na cor das camadas inferiores; 4) para se empilhar as folhas, era necessário esperar que secassem totalmente. Um filme comercial de 30 segundos usava em média 700 folhas de acetato. Somado a isso, os prazos apertados muitas vezes levavam ao acúmulo de trabalho no departamento de pintura, que chegava a ter 15 pessoas em um fim de semana para se concluir um filme. As trucas para filmagem podiam custar até U\$ $100.000,00$ e havia menos de 10 em São Paulo, segundo Galvão. Os curta-metragistas independentes utilizavam as trucas da ECA/USP e da TV Cultura.

Assim, não houve, por exemplo, quem não se desse conta do estardalhaço causado pela nova abertura do Fantástico em 1983, em que feixes de luz com as cores do arco-íris trespassavam várias vezes uma imensa pirâmide dourada, formando cinco plataformas que flutuavam no espaço (figs. 2, 3 e 4). Sobre elas, bailarinos usando fantasias estilizadas, repletas de referências geométricas, executavam uma coreografia ao som do tema do programa.
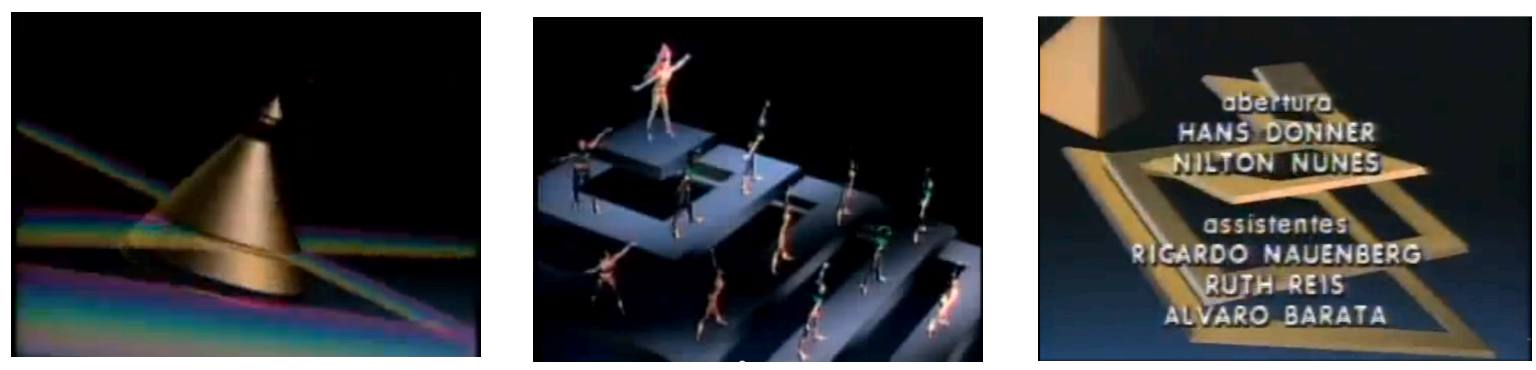

Figuras 2, 3 e 4- imagens da abertura do Programa Fantástico, da Rede Globo, de 1983.

Era evidente uma linha estética mais clean, em contraponto a todas as aberturas anteriores do programa. A repercussão deste trabalho foi mundial e por aqui, plantou entre todos os que trabalhavam com vídeo, se não o desejo de fazer algo novo, a consciência de um novo momento para a criação, embora esta tecnologia fosse inatingível. O designer austríaco Hans Donner, responsável pela criação desta abertura do Fantástico e por muitos outros trabalhos, celebrizou-se como o mago do design da Globo. "Ele era o gênio do design naquela época; hoje em dia todo mundo torce o nariz da existência do Hans Donner, mas o trabalho 
dele foi uma tremenda ruptura dentro da imagem de televisão no mundo e não só no Brasil; o que ele tava fazendo despertou interesse no mundo inteiro", comenta Alceu Baptista, cofundador da Vetor Zero.

Aficionado por ficção científica, pela série Star Treck e pelas ilustrações de Frank Frazetta e Moebius, Alceu Baptista também ficou instigado a saber como se chegava aos efeitos da abertura do Fantástico. Seu interesse em tecnologia e em artes levou-o a uma formação híbrida. Iniciou o curso de engenharia na Poli/USP, onde esperava aprender a montar um sintetizador de música eletrônica. Descobriu que o curso era mais burocrático e voltado ao trabalho empresarial, exigindo dedicação exclusiva ao estudo, o que lhe roubava o tempo de desenhar, sua verdadeira paixão (fig. 3). Prestou novamente o vestibular e entrou nas Artes Plásticas da ECA/USP. "Eu era um problema na Poli porque eu era artista demais e eu vim a ser um problema na ECA porque eu era tecnológico demais". Alceu conta que não se identificou com a arte contemporânea, mas o contato com estudantes de teatro, TV e cinema foi bastante frutífero, levando-o fazer aberturas de filmes super-8 e fantasias para o figurino de outras turmas.

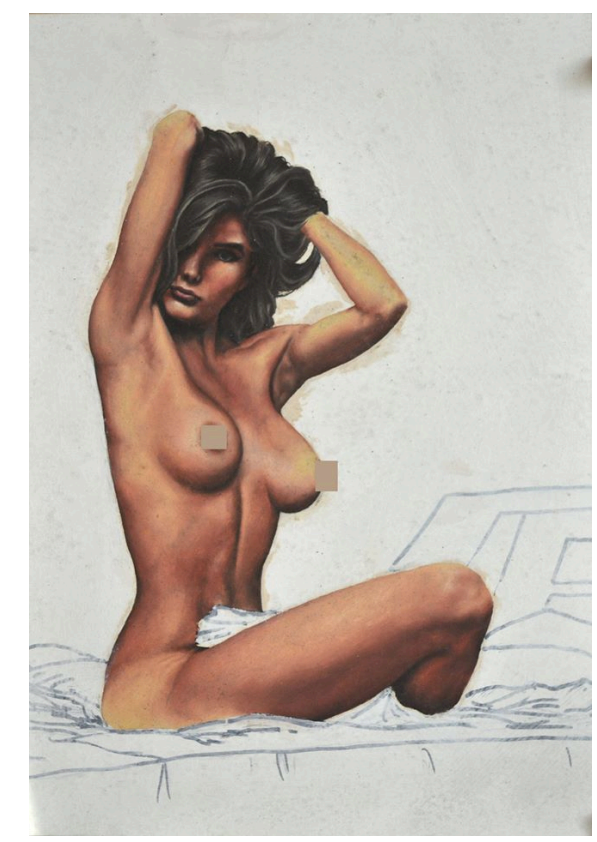

Figura 3 - ilustração de Alceu Baptista a óleo sobre papel, $1981^{89}$.

\footnotetext{
${ }^{89}$ Arquivo pessoal de Alceu Baptista.
} 


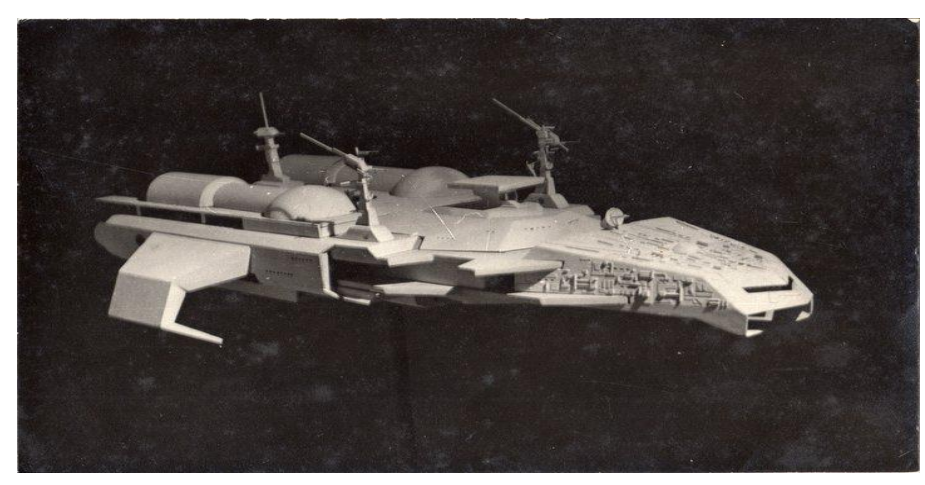

Figura 4 - nave espacial construída com sucata por Alceu Baptista ${ }^{90}$.

O fenômeno Star Wars impressionou-o mais pelos efeitos especiais do que pela narrativa, impulsionando-o a construir uma nave spacial (fig. 4) com sucata para o trabalho de uma disciplina curricular. Veio, então o desejo de fazer um filme de ficção científica, para o qual seriam necessários cenários, fantasias, o que, além da nave, consumiria know-how e recursos econômicos impensáveis naqueles anos.

Foi em 1984 que se desenhou uma oportunidade noticiada pela imprensa: um curso da Globotec $^{91}$, promovido pelo Cauby Sampaio do Monte ${ }^{92}$, para formação de profissionais na área de tecnologia digital para televisão. Havia uma seleção rigorosa:

[...] "eu preciso entrar nesse negócio, isso é o que eu quero fazer, tenho que ir atrás". Mas tinha um vestibular meio sério para entrar, e o curso era pago e caro. Nessa altura eu tava casado, minha mulher na época que era jornalista, ela falou: 'ok, você pode parar de trabalhar, parar de fazer ilustração e vai estudar pra esse vestibular aí, que eu te sustento'. [...] Eu só tinha mexido com computador na Poli, num grande computador e usando cartão perfurado. Ia ter prova de desenho, de matemática, português, inglês. E eu fui, prestei o vestibular e entrei; levei a espaçonave para os caras verem, todo mundo caiu de costa. (informação verbal) ${ }^{93}$

Outros candidatos que passaram nesta seleção foram: Gilberto Caserta, Luli Radfahrer e Geninho Galvão, entre outros cerca de 50 indivíduos sintonizados na frequência tecnológica, com afinidades comuns e competência intelectual semelhante. A expectativa destes jovens era a de trabalhar com 3D, ou 'computação gráfica', como era chamado na época. A turma foi apresentada em primeira mão, no Brasil, a trabalhos estrangeiros feitos em computação gráfica:

\footnotetext{
${ }^{90} I d$.

${ }^{91}$ Empresa criada em 1981, vinculada à Rede Globo, especializada em produzir vídeos comerciais, institucionais e vinhetas. EM 1990, tornou-se uma empresa independente da Globo, vindo a se chamar apenas G-TEC.

92 É considerado por Alceu Baptista o primeiro padrinho da Vetor Zero; foi ele quem pagou sua primeira viagem ao SIGGRAPH, em 1987, em Anaheim, Califórnia.

${ }^{93}$ Entrevista concedida por BAPTISTA, Alceu. Entrevista V. [out. 2013] São Paulo. Entrevistador: Maria Luiza Dias de Almeida Marques. 2013. A entrevista na íntegra encontra-se transcrita no Apêndice E desta monografia.
} 
[...] a gente via aquelas animações que hoje são breguinhas e simplezinhas, mas naquela época parecia extraordinário, era um novo tipo de imagem que 'tava sendo criada e que ninguém tinha visto, [...] havia esse encanto com aquela imagem que era diferente do que todo mundo conhecia. Aquelas câmeras que faziam imagens tridimensionais suaves, sem tremer; o que era de imagem aérea que a gente conhecia e que não tinha steady-cam, era tudo tremido, tudo balançando e tal; de repente sobrevoava uns prédios, nem que fossem prédios estilizados, mas com movimentos ultra suaves, aquilo era um coisa nova, uma percepção nova de movimento em televisão e em vídeo. (informação verbal) $^{94}$

Daniel Messias também conta que começou a prestar atenção nas vinhetas feitas pela Globo e inteirou-se de que o computador estava sendo aplicado em processos corriqueiros do trabalho como na pintura, na edição das imagens e na edição final do projeto, o que facilitaria muito o processo. Em resposta ao temor da equipe que se sentiu num primeiro momento ameaçada, Daniel comentou que eles teriam "que aceitar as mudanças e se atualizar. Você tem que estar pronto para se adaptar e assumir a mudança onde ela for interessante prá você." Para ele, a passagem do analógico para o digital não foi traumática e considera que soube tirar partido do computador, que passou a assumir todos os trabalhos de rotina, trazendo "conforto" à criação.

Walbercy corrobora: "é isso que eu digo, são as mudanças que você tem que fazer; hoje, todos esses equipamentos já foram pro lixo. Se você tiver o recurso, ou então você empresta um dinheiro, se aquele momento é o de virar, vê tem que virar".

\section{$\underline{\text { A evolução e os reflexos diretos nas produtoras Tradicionais }}$}

A necessidade de transição do sistema de produção analógico para o digital e a mudança na configuração dos estúdios partiu de uma demanda externa - as agências de publicidade - mas também de uma percepção interna de que, para se manter no mercado, impor-se-iam adaptações. Daniel Messias e Walbercy Ribas, para quem as publicações estrangeiras eram o canal de conexão com o que se fazia no exterior, contam que as agências traziam referências de comerciais americanos e europeus com propostas criativas, animações e efeitos inéditos no Brasil, resultados impossíveis de se obter com as ferramentas tradicionais. Segundo Daniel Messias, "as produtoras que não investiam iam ficando velhas e saindo do mercado; na agência sentia-se isso, e eles nos cobravam também".

${ }^{94} I d ., 2013$, p. 5. 
Dentro e fora do âmbito publicitário, diretores e gente ligada ao audiovisual buscava acompanhar a tendência do uso da tecnologia na criação. O primeiro contato de Arnaldo Galvão com um computador, por exemplo, foi em 1989, na produção do Rá-Tim-Bum, da Tv Cultura: "Desde o começo a ideia era que grande parte do projeto fosse digital, mas a burocracia era muito grande. Um dia o Fernando Meirelles entrou carregando um computador na cabeça e a equipe do Ratimbum teve algumas aulas de um soft chamado Tips, onde foram feitas algumas animações para o Ratimbum." (informação pessoal) ${ }^{95}$.

De posse de seu primeiro computador, um PC 486, em 1989, Daniel Messias sonhava ter uma workstation Sillicon Graphics, "uma espécie de Mercedes-Benz dos computadores", o que era inviável para estúdios menores. Segundo ele, a aplicação de som, de efeitos e a animação $3 \mathrm{D}$ adaptada para o $2 \mathrm{D}^{96}$ ganharam agilidade e limpeza, em todas as etapas do desenvolvimento dos filmes. Nos primeiros tempos, conta Messias, a maior parte das ofertas de software gráfico não era destinada à animação 2D, mas para a computação gráfica 3D; os softwares de pintura, por exemplo o Tips, eram de manuseio complicado. Até que um fabricante americano ofereceu por US\$ 8.000 a versão II do software $A X A$. Messias não tinha com quem se aconselhar, pois ninguém tinha este software e arriscou a compra junto com o aparelho de scanner.

Quando chegou aqui e a gente instalou, e isso eu tenho certeza, que a gente foi a primeira produtora [a adquirir o AXA], porque a TV Cultura veio logo em seguida, saber como funcionava, se era bom... E era bom, realmente ele funcionou direitinho... Esse ano foi 1993. Foi o ano em que a gente substituiu definitivamente e profissionalmente por um programa exclusivo de pintura digital feito pra animação. (informação verbal) ${ }^{97}$

Em 1992, a Start fez o segundo filme para a Faber-Castell (fig. 6), desta vez, em parceria com a Vetor Zero. O primeiro, de 1983 (fig. 5), tornou-se antológico na publicidade brasileira, e mostra a ilustração literal da canção "Aquarela" de Toquinho, com uma animação sofisticada, movimentos de câmera, metamorfoses e texturas, além de interação com objetos (produtos), obtida pelo penoso processo de aplicação quadro a quadro das fotografias previamente captadas e recortadas a mão: "dá um trabalho medonho e a fotografia sai sempre uma fotografia: cada hora que dá um banho [de revelação], a cor sai diferente, o tom sai diferente, então não era muito feliz, por mais que você caprichava, retocava tudo de novo".

\footnotetext{
${ }^{95}$ Entrevista concedida via e-mail em 29/03/2014.

${ }^{96}$ Messias refere-se ao desenho animado de personagens que aparecem manipulando embalagens também animadas. Um exemplo de composição dessas animações é o tigre da Kellogs segurando a caixa do cereal nas patas.

${ }^{97}$ Entrevista concedida por MESSIAS, Daniel. Entrevista III. [jan. 2013] São Paulo. Entrevistador: Maria Luiza Dias de Almeida Marques. 2013. A entrevista na íntegra encontra-se transcrita no Apêndice C desta monografia.
} 
No Faber-Castell II, o trabalho de animação 2D ficou com a Start e a parte da modelagem dos produtos e aplicação foi executada pela Vetor Zero:

'Tava começando a Vetor Zero. Nós fizemos a parte da animação e eles fizeram a parte de produto, já em computação gráfica: o lápis era computação gráfica. Nós estávamos comprando os computadores também; eles tinham comprado um computador, que era da Jovem Pan, se chamava TDI, francês, e começaram antes da gente a trabalhar. [...] E aí, a gente comprou o Topas, e começamos a fazer animação. [...] mas a gente não tinha muito interesse, era mais um elemento agregador, não era a nossa sobrevivência. Era... era mais prá fazer embalagem, produto, então ia agregar na animação. (informação verbal) ${ }^{98}$

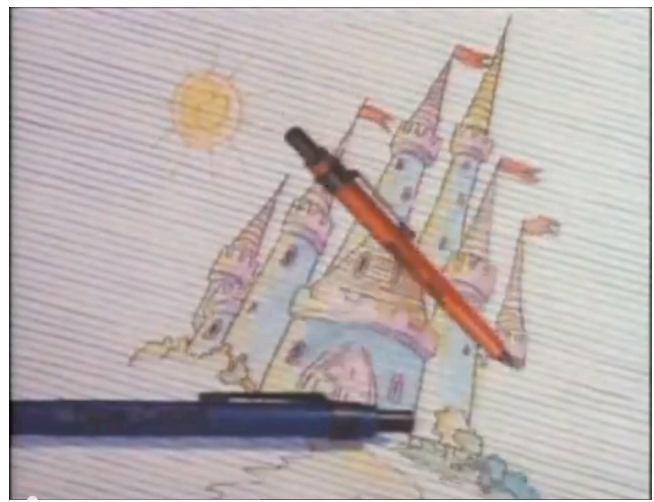

Figura 5- Imagem do filme Faber Castel, 1983. 1992.

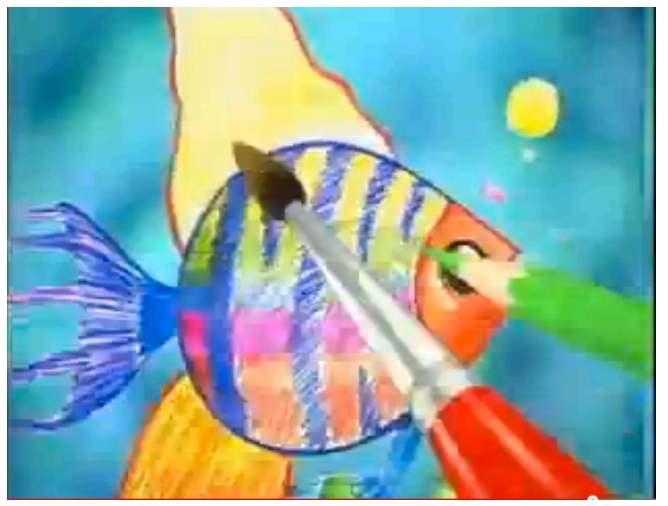

Figura 6- Imagem do filme Faber Castel II,

Com um investimento de U\$ 30.000,00, Walbercy conta que adquiriu um Topas em 1993, com Auto-CAD, e em seguida comprou um 3D-Studio, bastante superior ao Topas. A primeira animação com este equipamento foi um para um filme publicitário da marca Colgate para uma agência americana, em que seu filho Rafael, então com 14 anos, junto com outro funcionário da firma, Sérgio Spina, fizeram modelagem e animação em 3D.

Com esse sistema já era possível fazer a saída para vídeo e a inserção de personagens em ambientes virtuais ${ }^{99}$. Na sequência, por volta de 1995, ele adquiriu um Sillicon Graphics CPU verde - por U\$ 80.000, fora a placa gráfica e o software Alias Wavefront, que custaram, outros U\$ 45.000; este equipamento, o segundo no Brasil, de acordo com Walbercy, era usado prioritariamente em vinhetas, assinaturas e em packshots e seu filho passou a dominar o departamento de computação gráfica na Start. No decorrer de cinco anos, a Start enxugou a equipe de produção para dois operadores de computador (modelagem, animação 3D e scanner,

\footnotetext{
${ }^{98}$ Entrevista concedida por RIBAS, Walbercy. Entrevista II. [ago. 2013] São Paulo. Entrevistador: Maria Luiza Dias de Almeida Marques. 2013. A entrevista na íntegra encontra-se transcrita no Apêndice B desta monografia.

${ }^{99}$ No Apêndice B, Walbercy Ribas descreveu o complexo método de inserção de personagens no ambiente criado no Topas, em que faziam-se máscaras quadro a quadro na pós-produção, semelhante ao método analógico.
} 
pintura 2D) e três animadores fixos (animação 2D) e intervaladores free-lancers. Essa diminuição da empresa constituiu um processo iniciado alguns anos antes, em 1990, quando o Plano Collor acarretou a necessidade das primeiras demissões:

À medida que a gente ia evoluindo, nós extinguimos o acetato, nankim, a pessoa prá limpar o acetato, o líquido de limpar o acetato, extinguimos o negativo, a pessoa que cuidava do material de laboratório, a pessoa que fazia o ótico, a pessoa que filmava quadro a quadro. Praticamente o departamento foi todo extinto. Pessoas que pintavam o acetato, tudo isso foi extinto gradativamente. Isso já era 1994/95, mais ou menos. Aí a gente começou a se adaptar com o computador, e já em 1996 foi dissolvendo a equipe de animação também; você já não xerocava mais toda animação, você escaneava; aí você compra um equipamento melhor, você já não escaneava mais, pintava direto. Eu comprei vários programas; Toons, da Itália, a gente pintava tudo no computador, a arte final foi tudo... foi tudo abandonado, esses departamentos desapareceram. (informação verbal) ${ }^{100}$

A banda sonora dos filmes (trilha musical, ruidagem, locuções/diálogos) era mixada em um estúdio de som e chegavam à produtora em fita DAT, a qual era descarregada no disco rígido do Sillicon Graphics para ser sincronizada com a imagem. O Sillicon era conectado a uma ilha de edição BETA-cam, a qual gerava as cópias. Assim sendo, em 1995, já não se trabalhava mais com película em nenhum dos estúdios aqui estudados. Quando a Start adquiriu o segundo Sillicon Graphics (CPU roxa), o filme já saía pronto da produtora, sem a necessidade da contratação de serviços externos de finalização de imagem. Visto como um interventor pela maioria dos funcionários, o computador chegou para mudar a estrutura das empresas, alterando seu desenvolvimento e incomodando aqueles que não tinham familiaridade com a nova ferramenta. Nos estúdios pesquisados, a reação dos funcionários, principalmente os coloristas e técnicos de trucagem, foi diversificada: houve quem se dispusesse a aprender a lidar e conquistasse um posto novo na empresa e houve quem se incomodasse com o tempo ocioso, desertando do ramo da animação.

Embora a tecnologia traga facilidades, não há uma redução drástica no prazo de execução de um filme de publicidade. Um filme para a SHARP de um minuto levava três meses para ser concluído - concomitantemente com outros quatro ou cinco filmes. Um tão complexo quanto os da série SHARP, com minuciosa direção de arte, criado inteiramente em computação gráfica (3D) pode levar o dobro do tempo:

A modelagem de todos os produtos, personagens e objetos é o complicado. Demora muito. Preparação de cenário, detalhe. Tem que modelar tudo. Desenho animado, você fazia tudo num desenho só. Um radinho aqui, um objeto ali, isso você faz na hora. Faz o lay-out, passa pro acetato; em um dia

${ }^{100} I d ., 2013$, p. 11. 
você faz um cenário. Você não faz um cenário de computação gráfica num dia. Não existe isso. (informação verbal) ${ }^{101}$

Esta posição é reiterada por Daniel Messias em relação ao desenho animado 2D, o que se percebe em seu relato a respeito da produção do filme "Los Tres Amigos", de 2010, que, apesar de ser uma produção ficcional, financiada com verba da ANCINE, presta-se bem a exemplificar um modelo de demanda na era digital:

Ainda hoje existe uma percepção equivocada de que o computador veio prá abreviar prazos, prá diminuir custos, prá modernizar e prá resolver tudo na imagem; e não é verdade isso. Se o filme vai ser feito em Toon-Boom ${ }^{102}$ ou se vai ser feito em animação tradicional, isso é uma escolha difícil prá mim, mas por uma questão de prazo, por paradoxo que pareça, eu preferi a animação tradicional. Um filme de 10 minutos, a gente tinha o prazo ridículo de 3 meses, nem isso. E acabamos fazendo, deu certo, e eu tive mais uns 3 meses prá fazer a pré-produção. Mas prá fazer em Flash ou em Toon-Boom, eu precisaria de 6 meses, só pra criar todos os features vetorizados, criar o banco de dados de todos os personagens, eram montes de personagens, eu precisaria ter todos os story-boards prontos. (informação verbal) ${ }^{103}$

Com isso, Daniel Messias aponta para a complexidade da pré-produção e do planejamento de um filme criado digitalmente. Projetos como este, por ser ficcional e não publicitário, guardam uma relação custo-benefício para o produtor radicalmente diferente: não dão lucro. Mas por que fazê-los então? Messias responde:

São projetos interessantes, prá você se divertir, eu me diverti muito nesse projeto, os jovens que trabalharam também curtiram demais. A gente, eu dava risada nas sessões de pencil test, porque os diálogos são muito debochados, livre, era uma coisa tão livre que o filme não foi pro ar, é politicamente incorreto. Então, essa é a natureza do trabalho. São as coisas que valem a pena você fazer. Mas o preço que você paga é esse, não vai ter grana. Não vai ter prejuízo mas também não vai ter lucro... (informação verbal) ${ }^{104}$

\section{Cálculo do Orçamento X Valor pago pelo Mercado}

$\mathrm{O}$ orçamento de um filme publicitário reserva particularidades a serem comentadas. Ao serem questionados qual o impacto da tecnologia no modo de se calcular o orçamento de um filme, a discussão tornou-se complexa, incluindo fatores contextuais internos e externos à realidade de cada estúdio, o que resultou num embate entre o cálculo do orçamento e o valor que o mercado está disposto a pagar. Como já mencionamos, esta tensão é alimentada pela

\footnotetext{
${ }^{101}$ Ibid., 2013, p. 20.

102 Software de animação 2D do tipo cut-out.

${ }^{103}$ Entrevista concedida por MESSIAS, Daniel. Entrevista III. [jan. 2013]. Entrevistador: Maria Luiza Dias de Almeida Marques. 2013. A entrevista na íntegra encontra-se transcrita no Apêndice C desta monografia.

${ }^{104}$ Id., 2013, p. 8.
} 
falsa noção de que o computador reduz pessoal e custos. Sim, é inegável que, de uma certa maneira, a popularização em massa dos PC's domésticos trouxe facilidade para a produção audiovisual e aumento da concorrência, no entanto o que está em questão nesta pesquisa é o filme publicitário profissional com a exigência de qualidade que lhe é característica.

Como fatores internos, o fim da película e dos processos fotoquímicos e a redução do quadro de funcionários fixos, comum nos estúdios, enxuga a folha de pagamento mensal: no departamento de pintura, por exemplo, o trabalho de 5, 6 pessoas em 4 dias passou a ser realizado por uma única pessoa, em uma única diária. Dois motivos para a diminuição dos funcionários fixos são: a diminuição da quantidade de filmes (e, em consequência, aumento do intervalo entre os filmes) que aconteceu após o Plano Collor e o aumento da concorrência dado pela multiplicação de pequenas produtoras oferecendo filmes mais baratos e vídeos. Os encargos sociais elevados também dificultaram a manutenção da antiga estrutura.

Sem o quadro de funcionários fixos, cada filme demanda a contratação de freelancers, mão de obra especializada que tende a ser mais cara. Portanto, no cálculo do orçamento, extinguem-se alguns elementos da equipe, alguns se mantém e outros entram em cena. Daniel Messias enumera a seguir as contratações necessárias para um filme publicitário hipotético de sofisticação intermediária, em animação 2D tradicional, utilizando recursos digitais:

[...] um comercial é uma produção sofisticada, exige especialização. Você tem que ter um bom roteirista, um story-boardista, um bom diretor, que é caro, um bom animador, que é caro; esse animador vai ter que trabalhar com, no mínimo 2 assistentes, intervaladores, no mínimo 3 cleaners [...]. Aí já entra na área digital: você vai ter alguém que faça o escaneamento da imagem, alguém que faça a pintura digital, [...] um editor de imagem. Se tiver alguma animação 3D, tá aumentando a equipe, né? Animação 3D sempre tem. Às vezes, uma figura em 2D tradicional, um cartoonzão, pegando uma embalagem supersofisticada em 3D. Então, essa animação não é um cartunista 2D quem vai fazer, é o animador 3D. E se tiver que fazer rigging, modelagem, etc., é uma outra pessoa. E vai por aí a diante. Talvez vá ter alguém pra fazer a parte conceitual, se tiver grandes backgrounds, pintura, etc... Você está vendo como a equipe é grande? Depois, se você somar tudo isso, por mais que você tenha feito o cálculo no lápis, vai dar sempre um pouco mais do que aquilo que calculou. Normalmente, o orçamento hoje deveria ser muito mais alto. Mas o mercado não responde a isso. Esse que é o problema. As coisas não sobem simultaneamente, tudo, subiu também o faturamento das empresas... Você consegue, naturalmente, num filme 3D, uma coisa um pouquinho mais alta do que isso. Você consegue $\mathrm{R} \$ 80.000$, tal. Mas o custo dele vai ser também muito mais alto. (informação verbal) $^{105}$

A partir deste relato, vê-se que passados tantos anos da revolução digital, não houve muita mudança no valor de mercado dos filmes, passando de $\mathrm{R} \$ 60.000,00$ a $\mathrm{R} \$ 65.000,00$

${ }^{105}$ Ibid., 2013, p. 19. 
(valor atualizado) na animação pré-computação, para um teto de $\mathrm{R} \$ 80.000,00$, no caso específico de Daniel Messias, cujos orçamentos nunca ultrapassaram US\$ 1.000/minuto.

Observando o caso da Start, onde os orçamentos sempre foram mais volumosos, a discrepância na comparação entre os antigos orçamentos (da era analógica) e os novos (era digital) é nítida. Um filme feito em computação gráfica custa no máximo R\$ $100.000,00^{106}$, menos do que a metade dos filmes para a Sharp, que custavam em torno de US\$ 100.000. Walbercy comenta que os clientes dispõem-se a pagar cada vez menos, o que pode ser atribuído aos seguintes fatores externos aos estúdios: ascensão do vídeo e melhoria de sua qualidade, sofisticação das ferramentas digitais, barateamento das máquinas, aumento da concorrência entre novas produtoras, difusão da ideia de que o computador substitui trabalhos que, na prática, continuam requerendo habilidades técnico-artísticas.

Eu estou fazendo um filme que é mais ou menos por aí o preço, pra Copa do Mundo, mas vou dizer uma coisa prá você: você não ganha dinheiro. Você faz o filme defasado. Porque, se um elemento sozinho ficar fazendo o trabalho, porque eu crio, planejo, jogo prá eles animarem, tem que fazer a ficha de direção, anotar tudo, quer dizer, tem um tempo. [...] o cliente quer... a música, as vozes... e acontece que você faz todas essas coisas direitinho, você tem uma direção, um padrão, todas essas coisas têm que estar dentro de um contexto, né? Se eu cobrar o certo, seria cobrar R\$ 200.000. Com $\mathrm{R} \$ 200.000$, você ganha dinheiro. Hoje, o que acontece? se você paga um X de salário, ainda você dá uma gratificação prá pessoa, fica 3,4 meses fazendo, dissolve tudo. Você pega $\mathrm{R} \$ 100.000$ : $\mathrm{R} \$ 25.000$ por mês [de trabalho]. Tem outras pessoas, você não ganha nada. Não ganha dinheiro, mais. Antigamente você fazia muitos filmes, tinha um padrão de salários pré-estabelecidos. [...] No momento que chegou a computação gráfica, pulverizou tudo. Todo mundo podia aprender computação. (informação verbal) ${ }^{107}$

$\mathrm{Na}$ visão de Walbercy, que é complementar à de Messias, a vantagem prática da computação gráfica é trazida pela ausência de intervaladores, pela possibilidade de se texturizar e pela renderização.

Você anima na massinha, tudo cinza, depois você põe prá renderizar à noite; dia seguinte, você vê a cena; ao passo que a animação feita a mão, você vai ver a animação pronta: 'tá tudo errado isso aí, refaz tudo'. Volta a fazer do zero, tudo, esse é o problema. A computação gráfica veio facilitar a animação. E dá muito mais sabor ao filme, você transforma um filme de animação num filme quase real. Agora, a modelagem é que é complicada. Tem que ter equipe grande, muita gente modelando. (informação verbal) ${ }^{108}$

\footnotetext{
${ }^{106}$ Em 20/08/2013.

${ }^{107}$ Entrevista concedida por RIBAS, Walbercy. Entrevista II. [ago. 2013] São Paulo. Entrevistador: Maria Luiza Dias de Almeida Marques. 2013. A entrevista na íntegra encontra-se transcrita no Apêndice B desta monografia. ${ }^{108} I d ., 2013$, p. 20.
} 
Tanto para Messias quanto para Ribas, manter a lucratividade dos tempos da produção analógica é impossível. Os grandes estúdios precisaram diminuir para não sair totalmente de cena e forçosamente dividiram sua parcela do mercado com gente nova. Também foi possível notar que a revolução digital aconteceu em um momento em que a postura empresarial dos proprietários desses estúdios também estava sendo revista. Walbercy declarou seu descontentamento com uma certa padronização das propostas publicitárias e com a falta de ousadia, o que foi buscar na produção do seu longa-metragem, O Grilo Feliz. Enquanto produzia o longa, conduzia sua empresa produzindo filmes para publicidade, de menor impacto. Daniel Messias, que nunca quis "ampliar [a empresa] ao nível que virasse uma enterprise", reformulou paulatinamente a empresa, tornando-a mais minimalista. Suas especialidades, criar e dirigir, independem de equipe, que ele terceiriza a cada projeto. Entre 1995 e 1996, a nova configuração foi definida por completo, mantendo-se até os dias atuais. 


\section{Capítulo 5 - Gente nova no pedaço}

O mesmo movimento provocado pela chegada da tecnologia que afetou as produtoras já consagradas no mercado, semeou a possibilidade de empreendedorismo em uma nova geração de profissionais e estudantes de áreas distintas, ansiosos pela realização audiovisual, com poucos recursos financeiros e, sobretudo, sem a possibilidade de competir em pé de igualdade com os estúdios tradicionais. A animação representou, para muitos deles, a convergência de seus interesses e pesquisas artísticas, resultando, em certa medida, trabalhos mais experimentais.

Ao passo que Walbercy Ribas e Daniel Messias agregavam os novos equipamentos à sua expertise em animação tradicional, ampliando o que tinham a oferecer e buscando se equiparar às tendências internacionais, Alceu Baptista e Guto Carvalho garimpam oportunidades para oferecer um diferencial talhado no uso de tecnologia de baixo custo mas alinhado às suas personalidades e interesses.

Em meados dos anos 1980, o setor gráfico já vinha adotando equipamentos de editoração eletrônica e de impressão, prioritariamente com produtos Apple. Uma dessas empresas, a Multi-Soluções, bem estabelecida no ramo de desktop-printing, abriu o caminho para o surgimento de um estúdio novo de animação. Vale retomar o relato de Guto Carvalho, que traz uma visão privilegiada do processo de digitalização da empresa onde trabalhava, a New Vision. Ele, que havia passado 4 meses em NY para aprender a lidar com o mainframe recém-adquirido pela New Vision ao custo de cerca de US\$400.000, uma plataforma com arquitetura Windows, conheceu lá outro produto do mesmo fabricante, o sistema Macintosh, que custava entre US\$ 3.000 e US\$ 4.000. O equipamento em questão chamava-se Digital Effects, ou D-Effects, e consistia basicamente em uma suíte de edição que controlava os VT's e fazia o processamento quadro a quadro das imagens, permitindo que se trabalhasse com elas em ambiente digital, ou seja, basicamente o mesmo trabalho executado pelo mainframe, com a diferença de que as imagens não eram descarregadas em tempo real, mas quadro a quadro.

Ao recordar a época em que montou sua produtora, a Trattoria di Frame, Guto Carvalho recorda que a Multi-Soluções teve um papel importante: seu proprietário havia adquirido um computador Apple, o mesmo que Guto conhecera nos EUA, com funcionalidades voltadas para criação em vídeo. Sem encontrar serventia para esta máquina, quis vendê-la ao dono da New Vision, o qual recusou a oferta, transferindo-a ao seu funcionário que conhecia esse sistema, Guto Carvalho. Por um valor simbólico, Guto e 
Guilherme Ramalho aproveitaram a oportunidade em troca do uso deste equipamento no showroom da Multi-Soluções:

\begin{abstract}
Dessa oportunidade, desse cara que havia trazido uma máquina, um Macintosh, mas que ele não sabia prá que era que funcionava, não sabia usar a máquina, e eu sabia usar, a gente [...] montou uma produtora baseada neste primeiro Macintosh. [...] A gente sim reproduzia o ambiente da New Vision, reproduzia um ambiente high-tech, mas na escala pessoal, com computador pessoal, não com um computador... e fomos sim ousados em afirmar com certeza que a gente conseguiria fazer efeitos e soluções gráficas muito interessantes num computador pessoal coisas que só eram possíveis em estações muito caras. (informação verbal) ${ }^{109}$
\end{abstract}

Desta forma, o primeiro computador da Trattoria di Frame foi adquirido em 1991, um Apple Quadra 900, com processador de $25 \mathrm{MHz}$, memória RAM inicial de 4MB com capacidade de expansão até $256 \mathrm{MB}$ e HD com cerca de $400 \mathrm{MB}$ de memória no disco rígido que, segundo Carvalho, dificilmente era preenchido. Com este equipamento, a Trattoria realizou um dos seus primeiros trabalhos, que consistia em um efeito especial inicialmente encomendado à New Vision pela agência Leo Burnett, para um comercial de cigarros Marlboro. A New Vision não alcançou o resultado desejado, o que foi uma oportunidade para Carvalho oferecer seu trabalho, a ser feito no Quadra 900.

A parceria estabelecida entre a Multi-Soluções e a embrionária Trattoria di Frame mereceu divulgação na imprensa - através da assessoria de imprensa da Multi-Soluções - o que rendeu matéria de capa do caderno Informática na Folha de São Paulo, que publicou inclusive o número do telefone da Trattoria, e atraiu a atenção para a estreia de um novo conceito em criação: o Desktop-Video, derivado do Desktop-Graphics/Printing.

Como resultado dessa divulgação, o diretor de arte da W/Brasil, Jarbas Agnelli, entrou em contato na expectativa de transformar um conjunto de imagens criadas no Adobe Illustrator em vídeo de animação, para uma campanha de preservativos Olla. O trabalho em questão consistia em colocar diversas imagens no formato pict em sequência e gerar um arquivo de vídeo no formato Quicktime. A animação 2D resultou um desenho animado minimalista, em que se vê um exército de espermatozóides nadando ao ritmo da Cavalaria Rusticana (figs. 1 a 4). O bom humor e a simplicidade técnica mereceram um Leão de Bronze em Cannes em 1992, rendendo visibilidade à Trattoria, que executou apenas a parte técnica do trabalho, sendo do Agnelli o mérito artístico.

\footnotetext{
${ }^{109}$ Entrevista concedida por CARVALHO, Guto. Entrevista IV. [set. 2013] São Paulo. Entrevistador: Maria Luiza Dias de Almeida Marques. 2013. A entrevista na íntegra encontra-se transcrita no Apêndice D desta monografia.
} 

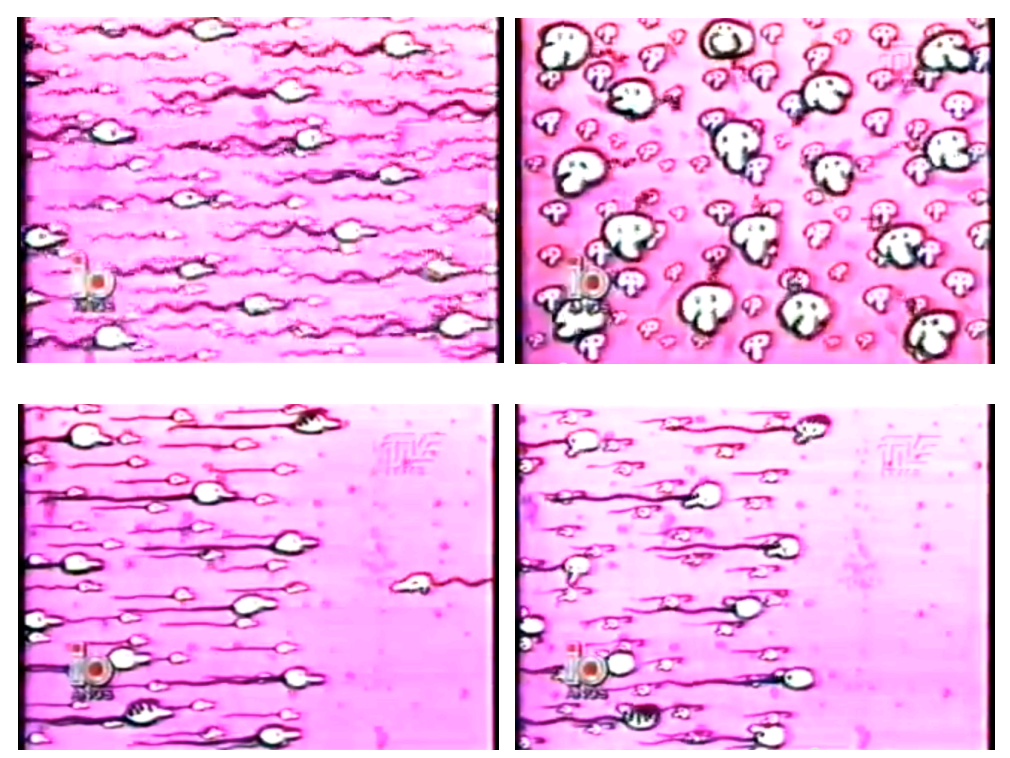

Figuras 1, 2, 3 e 4 - sequência de imagens do filme da campanha de Olla(sequência: da esquerda para a direita, de cima para baixo).

Este trabalho apontou para a possibilidade de fazer animação com um profissional que não fosse exatamente um animador, mas que tivesse habilidades diversificadas, em ilustração ou em design, trazendo o conceito do desktop-printing para o vídeo. Na opinião de Carvalho, este filme determinou o surgimento de um novo tipo de filmes no mercado do cinema de animação: "Era um filme totalmente digital, este filme não tinha sido papel nunca na vida. $\mathrm{E}$ também não era 3D, [...] que já tinha a sua linguagem." (informação verbal) ${ }^{110}$

Transitando em outra esfera, em termos de criação e de repertório, Alceu Baptista teve contato com equipamentos de ponta durante a imersão no curso da Globotec, tempo em que aprofundou seus conhecimentos em programação, mesclando-os com suas técnicas em ilustração. Ainda que o curso não disponibilizasse máquinas para os estudantes, havia aulas práticas realizadas na Globotec, onde alguns dos equipamentos eram o Ultimate e o Newsmate, equipamento para recorte do fundo azul e aplicação em outro cenário, muito usado em telejornalismo, o Paint System Digital, que permitia parar um frame e pintar por cima, como na abertura da série Armação Ilimitada. Havia na sede da Globo, no Rio de Janeiro, um equipamento mais sofisticado, próprio para animação 3D, o Cubicomp Picture Maker, que não foi transportado para São Paulo por questões políticas internas da Globo, o que causou grande frustração entre os participantes do curso. De todo modo, a respeito deste período, comenta Baptista:

[...] eu trouxe para dentro do digital, a minha habilidade como ilustrador, e o que foi um choque para os caras que trabalhavam com tecnologia, porque os

${ }^{110}$ Id., 2013, p. 7. 
caras vinham de uma formação tecnológica. Quando eu apliquei a ilustração ali, ninguém acreditava no que eu conseguia fazer: "nossa! Como você desenhou isso, e como você fez isso?", ninguém entendia: 'isso aqui é um simples truque de ilustração', então a gente conseguia fazer umas coisas que ninguém conseguia e esse foi o segredo da Vetor no começo. (informação verbal) $)^{111}$

Com poucas empresas equipadas e aptas a trabalhar com a computação gráfica, a fatia do mercado a ser explorada era promissora:

Quem fazia animação? Tinha o José Dias, que fazia animação para a Globo; tinha umas duas empresas trabalhando com Cubicomp Picture Maker, uma delas chamava Pixel; e tinha o Ormeu, que tinha lá no Rio a empresa Azimuth, mas ainda em estágio embrionário. E tinha o pessoal que trabalhava com AppleII, e que fazia umas animaçõezinhas e tinha até um programinha chamado Take Five, que permitia fazer animaçõezinhas 2D rudimentar, mas o pessoal trabalhava com isso e fazia animação institucional de baixa resolução e em escala bastante precária. (informação verbal) ${ }^{112}$

No relato acima, Baptista refere-se, ao programa Take One, compatível com o Apple $\mathrm{II}^{113}$, que poderia ser adquirido com um pacote de imagens prontas, cenários e personagens, para se animar no ambiente do software ou com um programa de desenho para a criação de imagens originais.

Numa época em que o diálogo entre arte e tecnologia digital ainda engatinhava, Guto Carvalho e Alceu Baptista souberam enxergar e criar oportunidades valiosas para sua inscrição no universo da criação digital, ao fundir a tecnologia nascente com o tipo de expressão a que estavam familiarizados.

Tais oportunidades são observadas quando Baptista, nos conta, por exemplo, que, ao término do curso da Globotec, pairou uma frustração generalizada, por não ter tido contato suficiente com a tecnologia. O sistema Cubicomp Picture Maker 2.0 custava cerca de US\$ 20.000, montante impensável para qualquer um dos que frequentaram o curso. Foi quando surgiu no mercado o computador Amiga, por US\$2.000, que era uma evolução do Commodore 64. O primeiro modelo do Amiga foi lançado em 1985 como um high-end home computer e tornou-se popular entre os entusiastas da computação por seus recursos gráficos e de áudio. O modelo Amiga 500, de 1987, foi o mais vendido e representou uma verdadeira possibilidade de entrar na computação quando, de volta às ilustrações, Baptista fez um panfleto para V-TV, produtora do Sérgio Sales, então estudante da ECA/USP. Baptista

\footnotetext{
${ }^{111}$ Entrevista concedida por BAPTISTA, Alceu. Entrevista V. [out. 2013] São Paulo. Entrevistador: Maria Luiza Dias de Almeida Marques. 2013. A entrevista na íntegra encontra-se transcrita no Apêndice E desta monografia. ${ }^{112}$ Id. 2013, p. 9.

${ }^{113}$ Equipment required: Apple IIc, IIe, 64k and Applesoft Basic in ROM.
} 
mostrou-lhe o catálogo do amiga e convenceu-o a adquirir um, o que resultou na sociedade entre os dois com a criação da Vetor Zero, em 1986. A narrativa vívida de Baptista a respeito da compra do seu primeiro computador traduz a atmosfera da época:

[...] a gente comprou o Amiga e ficamos 03 meses na expectativa de chegar, e ficamos lendo, e eu só pensava naquilo, ansiedade e tal. Quando chegou no RJ, o Serginho [...] fez um bate e volta com um amigo, e eu fiquei esperando no meu apartamento, metade do pessoal do curso da GLOBOTEC estava lá esperando o computador chegar. E chegou, montamos o Amiga, ligamos o computador e fez um barulhinho... apareceu para botar um disquete e a gente colocou o disquete do sistema operacional, e aí apareceu para por outro disquete, colocamos, e aí apareceu uma tela colorida... Oh! tinha 32 cores simultâneas na tela e a gente nunca tinha visto, foi um acontecimento. E aí começamos trabalhar com Amiga e não tinha os softwares, não tinham chegado, e eu comecei a mexer com aquilo, e comecei a programar em basic as coisas que eu tinha aprendido na GLOBOTEC, comecei a usar os recursos que tinha, desenhar num Paint System rudimentar que eles tinham lá. E quando o software chegou, no dia seguinte entrou no job, SENAC, foi o $1^{\circ}$ trabalho, e a gente conseguiu nesse $1^{\circ}$ job pagar o computador. Afinal eram mil dólares. (informação verbal) ${ }^{114}$

Os primeiros trabalhos eram em $2 \mathrm{D}$ pois o Amiga não tinha capacidade gráfica para processar 3D. Desenhava-se com o mouse e se procurava transpor a linguagem da ilustração para as animações, buscando simular um efeito de espacialidade tridimensional. "Não dava para fazer metálico de verdade, mas a gente pintava umas coisas que pareciam metálicas, e para os olhos destreinados das pessoas da época, aquilo parecia metálico". Durante dois anos este primeiro computador foi suficiente para suprir a demanda de vídeos da categoria low-end, como Baptista denominou esta faixa do mercado dos vídeos empresariais e institucionais. Segundo ele, o high-end era produzir 3D para comerciais, coisa que a Globograph, a Pixel, a Azimuth, a Diana e a Intelligent Lights faziam. Esta última contava com um sistema de computador acoplado a uma câmera de filme que imprimia direto na película, um equipamento chamado film printer, para posteriormente executar a telecinagem. Na Diana e na Globotec, o material do computador era descarregado diretamente em fitas magnéticas de uma polegada.

O sistema de saída possibilitado pelo Amiga previa a gravação da animação do computador diretamente para a fita de VHS, ao acionar o play da animação no Amiga junto com o rec do gravador VHS. Em outra produtora, transcrevia-se este material do VHS para fita U-Matic. Entretanto, era necessário valer-se de um artifício para driblar a velocidade inconstante do play do Amiga :

${ }^{114}$ Id. 2013, p. 8. 
[...] a gente tinha que usar um truque porque o play do Amiga, não era um play smooth, não era um play constante, ele variava em função ao que o computador estava calculando naquele tempo, e ele era meio quebradinho; pra evitar esse quebradinho, eu e o Serginho, conversando, experimentando, vimos um jeito. Detalhe: o Amiga tinha uma saída direto para vídeo, e era o que os outros também não tinham, então você gravava no VHS ou você gravava em U-Matic, na saída de vídeo do Amiga, embora fosse um vídeo meio escuro, meio assim, não muito legal do ponto de vista técnico, mas dava para gravar direto do computador. Então a gente soltava a animação em super slow motion, porque aí o computador conseguia usar mais ou menos o mesmo tempo para calcular cada frame; e aí a gente ia para uma empresa que tinha um sistema um pouquinho melhor de Vídeo U-Matic, e a gente fazia um tape-to-tape, em fast speed, então a gente acelerava a animação, para que ela finalmente ficasse no tempo... tinha [uma pequena perda de geração], mas a qualidade já era péssima; ainda assim, era um bom trabalho. (informação verbal) $^{115}$

As produtoras que nasceram sob o signo da tecnologia digital mas buscaram sua identidade na pesquisa estética marcaram seu diferencial e conquistaram seu espaço através de um discurso evocador da arte, do refinamento cinematográfico, da modernidade. Constatase assim, que a expertise das empresas deste segundo bloco da pesquisa, Vetor Zero e Trattoria di Frame, consistiu em, antes de mais nada, saber avaliar o alcance da computação e conseguir extrair o máximo dos dispositivos na direção de um objetivo pré-determinado. A isso, somam-se obstinação, senso de oportunidade, domínio técnico e talento.

Por este prisma, os fundadores da Trattoria di Frame, que traziam uma intensa vivência com o pessoal de cinema publicitário desde os tempos da New Vision e compreendiam bem este universo, e rapidamente previram como a "lógica dos computadores" poderia subverter uma ordem cristalizada pelo modo de produção analógico. A opção pelo método de criação digital não os impediu de incluir película e desenho no papel como fonte de pesquisa de linguagem, o que, em grande parte, fez com que o portfolio da Trattoria se tornasse referência em liberdade de criação em diferentes processos de realização.

No início da carreira, quando não competia em pé de igualdade material com a Globograph, Globotec e outras que se vendiam com um discurso tecnológico do tipo "venham fazer 3D conosco porque nós temos a mesma máquina que fez o filme $\mathrm{X}$ ", ou "nós trabalhamos com Sillicon Graphics, a tecnologia mais avançada e a disposição do seu filme”, o discurso de promoção da Vetor caracterizava-se pela exortação de sua qualidade artística, cinematográfica.

[...] a gente começou a disputar mercado com o Zé Dias [da Globograph], só que claro que ele levava grande vantagem de ter a estação gráfica superior e

\footnotetext{
${ }^{115}$ Id. 2013, p. 9.
} 
ter o nome da Globo e ter o trabalho do Hans Donner, um trabalho bom; mas para nossa felicidade a Globo resolveu fechar a Globograph. Acharam que não era uma boa ideia, não era bom negócio e tirou ela do mercado, então a gente conseguiu avançar daí pra frente. (informação verbal) ${ }^{116}$

A inserção dessas jovens produtoras no mercado demandou o aprendizado da linguagem do cinema publicitário, que exige inteligibilidade e identificação. A apropriação desta linguagem e sua conjugação com inovação tecnológica de baixo custo garantiram à Trattoria e à Vetor um espaço cada vez maior entre as produtoras grandes, com filmes que caíram no gosto do público e dos clientes.

A adesão e a rejeição do público a uma determinada "visualidade" são sujeitas a um amplo contexto sociocultural, cabendo às pesquisas de opinião conjugadas com a sensibilidade dos criadores (agência e/ou produtora) apropriar-se do que já existe e incluir novos elementos para lançar uma nova campanha.

A respeito desse processo de educação do olhar e de apropriação estética, Carvalho forneceu um exemplo interessante que ilustra o caminho de uma proposta experimental "obscura" rumo à sua popularização:

Eu me lembro quando surgiu o efeito Matrix, por exemplo, do time slice ou bullet time ${ }^{117}$, que seguiu exatamente essa trajetória de ter sido feito num curta, chamado Temps Morts, lá em 1995. Depois foi num clipe de uma bandinha independente, depois no clipe dos Rolling Stones, depois no filme Matrix. E depois, na publicidade brasileira. (informação verbal) ${ }^{118}$

Baptista ressalta que sua produtora foi estigmatizada negativamente no início como não artística, "porque as pessoas achavam: 'isso aí é feito por computador', e aí as pessoas não tinham noção do trabalho humano que havia por trás." A esse preconceito soma-se uma visão equivocada de que qualquer coisa poderia ser feita digitalmente, ou seja, "uma expectativa de que o computador poderia fazer coisas que só hoje a gente consegue fazer, 30 anos depois". Como exemplo dessa mentalidade, Baptista citou uma animação para o vídeo institucional da Citrosuco, feita em 1988, (figs. 5 a 10), o primeiro grande trabalho da Vetor Zero:

O cliente queria "que o suco de laranja preenchesse o logotipo de vidro, jorrando, com splash em câmera lenta, coisa que hoje ainda é difícil de fazer, mas as pessoas achavam que, já que é o computador que sintetiza a imagem, dava para fazer tudo. [...] você tinha que fazer uma certa educação para o

\footnotetext{
${ }^{116}$ Id. 2013, p. 16.

${ }^{117}$ A partir dos experimentos de Muybridge, Tim Mcmillan desenvolveu em 1980 um dispositivo composto de múltiplas câmeras para se fotografar um objeto ou um evento em três dimensões. Tal efeito foi atualizado no filme Temps Mort, de Emmanuel Carlier, em 1995.

${ }^{118}$ Entrevista concedida por CARVALHO, Guto. Entrevista IV. [set. 2013] São Paulo. Entrevistador: Maria Luiza Dias de Almeida Marques. 2013. A entrevista na íntegra encontra-se transcrita no Apêndice D desta monografia.
} 
pessoal não viajar demais, mas a gente recebia coisa de criação delirante. (informação verbal) ${ }^{119}$
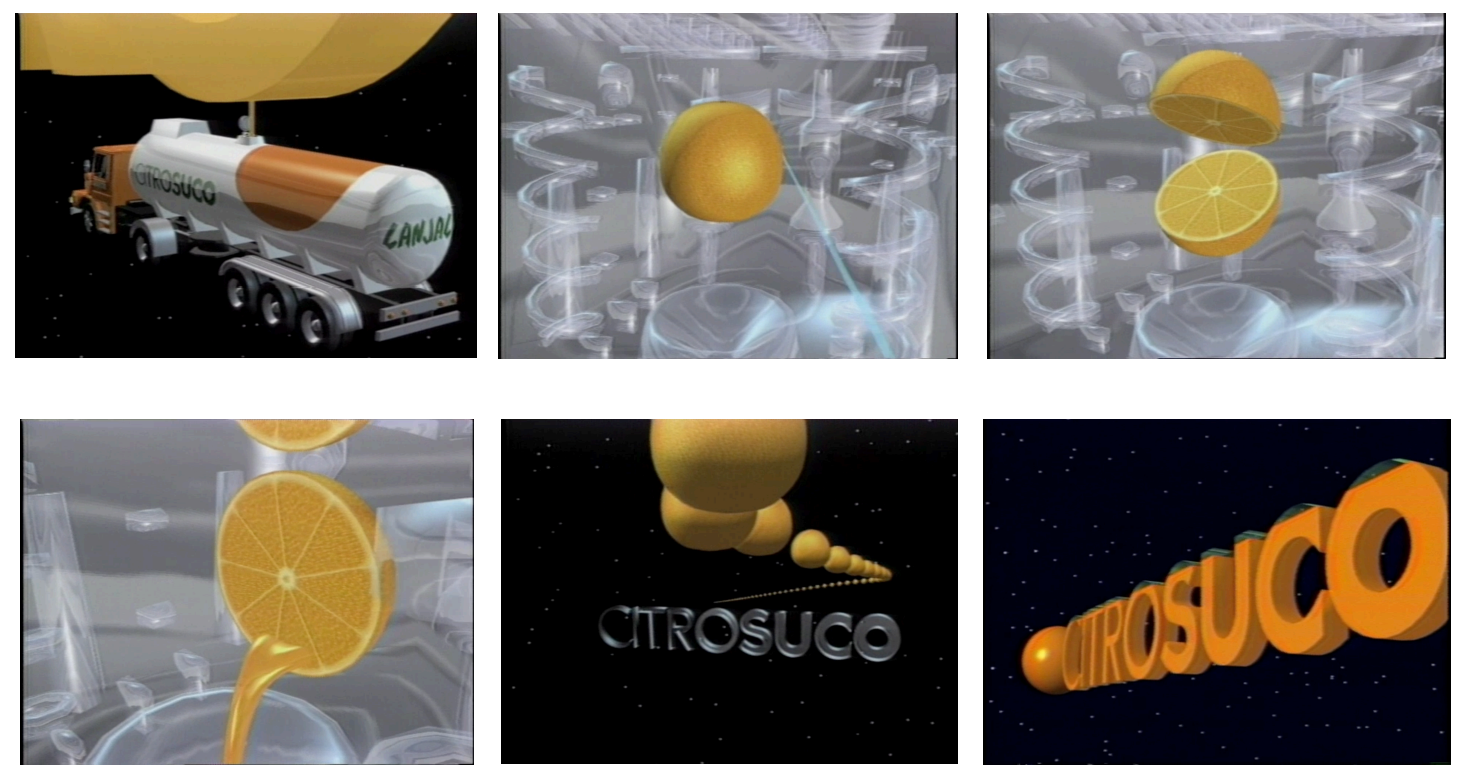

Figuras 5, 6, 7, 8, 9 e 10 - sequência de imagens do filme Citrosuco.

\section{Os Processos nas novas produtoras}

A partir das entrevistas, elegeram-se algumas questões comuns a todas as produções dos filmes de animação, o que propiciou a observação de diferentes modos de tratamento de problemas. Como nos filmes analógicos, desde a concepção até a finalização dos filmes, as produtoras da era digital lidam com questões ditas "artísticas" e outras burocráticas, ou administrativas, o que vamos relacionar a seguir, iniciando pela temática do relacionamento das produtoras com as agências de publicidade e pelo layout artístico, animação, equipe, orçamentos e finalização.

Carvalho distingue três momentos na relação com as agências na elaboração de uma proposta de direção e layout dos filmes na Trattoria: "primeiro, quando era mais coletivo, [...] todo mundo fazia um 'toró de parpite', todo mundo dava suas ideias, sugestões, selecionávamos umas tantas e chegávamos numa proposta coletiva que era apresentada [na agência] pelo diretor." Dez anos mais tarde, há uma formalização deste processo, passando o diretor a buscar na agência o brieffing a partir do qual trabalhava com um diretor de arte e com um profissional de pesquisas que buscava referências para alimentar a construção

\footnotetext{
${ }^{119}$ Entrevista concedida por BAPTISTA, Alceu. Entrevista V. [out. 2013] São Paulo. Entrevistador: Maria Luiza Dias de Almeida Marques. 2013. A entrevista na íntegra encontra-se transcrita no Apêndice E desta monografia.
} 
estética do filme, a definição de um look, e a elaboração de duas propostas para retornar às agências. Num terceiro momento, com a evolução da internet, as agências passaram a fazer suas próprias pesquisas e a solicitar das produtoras a realização de uma ideia pré-determinada. $\mathrm{Na}$ visão de Carvalho, isso representou um retrocesso, na medida em que a criatividade deu lugar à reprodução de soluções já testadas, em que muitas vezes a técnica e a linguagem eleitas não eram adequadas à mensagem. Resumidamente, no início, as produtoras eram chamadas a colaborar e a propor soluções, e hoje as agências já têm a proposta pronta: "é isso que a gente quer". Já Baptista discorda enfaticamente de Carvalho: "Não. Eles não sabem hoje em dia o que eles querem."

Concluído o processo descrito acima (decupagem, story-board e tratamento visual do filme), surge, com os meios digitais, mais uma etapa de produção, a pré-visualização para aferição do ritmo das cenas antes do trabalho de animação propriamente dita. Materializada na forma do animatic, passou a ser uma etapa imprescindível, em todos os filmes, incluindo os filmes com atores "ao vivo".

Na Trattoria, a cultura do animatic surge atrelada à produção de cd-roms ${ }^{120}$, em que as versões beta, não funcionais, permitem o aperfeiçoamento do produto final. $\mathrm{O}$ animatic permite a redução de erros e correções de percurso o quanto antes. "O fato de sempre fazer publicidade, trabalhar com duração fixa, e muito curta, ajudou muito. Objetiva muito a realização", comenta Carvalho. Assim, depois da definição do story-board, ele passava por etapas: animatic, lay-out de animação (preto-branco), lay-out semifinalizado (colorido).

De um modo geral, a gente apresentava o animatic na reunião de produção. Porque a gente sempre teve como política, trabalhar da maneira mais pública possível. Ou seja, as decisões a respeito do filme eram tomadas ao longo do processo. Tudo era muito pactuado, combinado, discutido exaustivamente, pra que ao final não tivesse surpresas. (informação verbal) ${ }^{121}$

Após a aprovação das definições, inicia-se a produção da animação em $2 \mathrm{D}, 3 \mathrm{D}$ ou técnicas mistas. A animação 2D na Trattoria, conforme a linguagem pedida pelo filme, podia ter dois tratamentos: o tradicional, no papel (posteriormente escaneado e finalizado digitalmente), com suas diversas aplicações ${ }^{122}$ ou diretamente no HD do computador, com os softwares da Adobe: Illustrator, para desenhos vetoriais; Photoshop, para colorir e tratar imagens; After Effects, para montar a sequência de imagens, fazer composição e animar; Première, para editar, adicionar a trilha; e da Macromidia: Director, para desenhar, animar e

\footnotetext{
${ }^{120}$ A Trattoria teve um braço chamado Trattoria Digital, que produzia cd-rom multimídia.

${ }^{121}$ Id.,p. 92013.

122 Animações 2D poderiam ser recortadas e coladas em chapa de metal ou papelão para ser fotografadas quadro a quadro, resultando um stop-motion.
} 
produzir cd-rom multimídia. Pela sua identidade multifacetada, a técnica do stop-motion foi resgatada para a produção de publicidade, rendendo filmes antológicos como o do chocolate Tortuguitas.

É importante observar que o espaço físico da produtora, bem como equipamentos e profissionais, frequentemente eram colocados à disposição de quem tivesse algum projeto experimental em animação. É o caso do filme Amassa que elas gostam (fig. 11), de Fernando Coster (lançado em 1998), em que uma atriz de carne e osso se apaixona por um boneco de animação de filmes pornográficos. O filme foi totalmente rodado em película, mas inovou por fazer a primeira experiência de stop-motion monitorado por uma câmera de vídeo conectada ao computador no Brasil. As imagens eram enviadas quadro a quadro para o Première, onde se podia assistir à animação antes de "clicar" o fotograma na câmera de cinema. Desta forma, se o movimento do boneco/objeto não estivesse de acordo com o planejamento do animador, podiam-se efetuar correções, antes de captar a imagem na película.

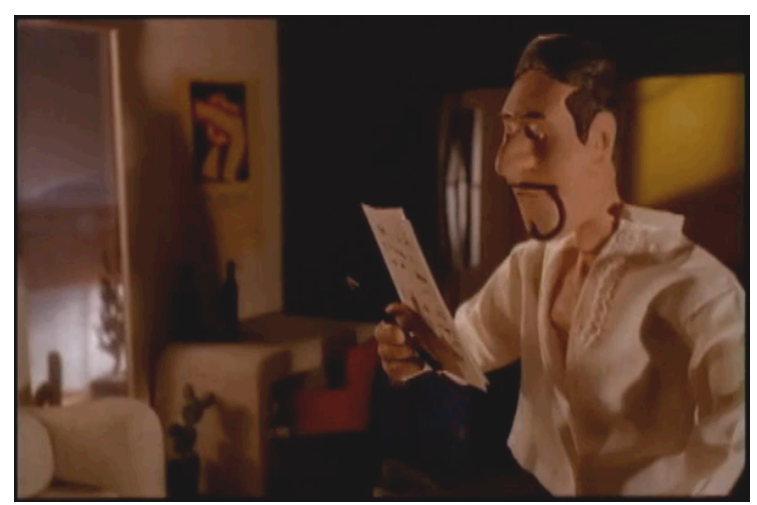

Figura 11 - fotograma do curta-metragem Amassa que elas gostam.

Já a produção na técnica 3D passou por vários momentos ao longo da evolução das plataformas de trabalho. Nos primeiros tempos, à época do Cubicomp, a modelagem e a animação exigiam conhecimentos em programação e os comandos eram dados pelo teclado, como exemplifica Baptista: "marca o ponto e anda 03; marca um ponto e desce 03; vira; completa; extrude; menu sobe; poligon; extrude; volta; gira; seleciona; corta; boleana; tudo comando." O vídeo de treinamento do Cubicomp, de 1987, mostra um homem de terno e uma moça de tailleur (um contraste evidente com o estereótipo do "artista") que executam comandos numéricos de modelagem, e encorajam: "with a little practice, you'll be producing sophisticated models and animation such as this..." ${ }^{123}$ (figs. 12 e 13).

\footnotetext{
123 “com um pouco de prática, você vai produzir modelos e animação sofisticados como estes” (tradução nossa)
} 

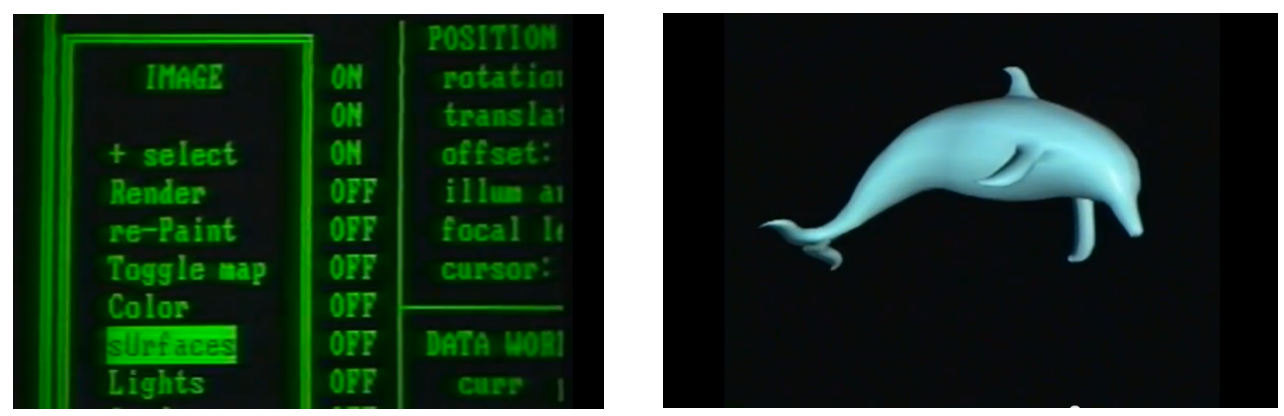

Figuras 12 e 13 - menu da interface de modelagem e objeto modelado no cubicomp.

No sistema Cubicomp, a pré-visualização das animações, o preview, só era possível ao final do trabalho, em wireframe ${ }^{124}$, depois de várias horas, num processo de adição, ou sobreposição, de imagens: à medida em que imagens novas eram geradas, elas se somavam às anteriores, excluindo-se as primeiras. Baptista conta que em um de seus primeiros trabalhos, eles só puderam visualizar a animação por completo após dois meses de trabalho, quando a animação foi descarregada: o material de 40MB levou 6 horas para ser transferido para uma fita magnética, a qual rodava num equipamento conectado ao monitor.

Já no sistema Sillicon Graphics, aquirido para que a Vetor ascendesse ao mercado high-end ${ }^{125}$, a visualização da modelagem acontecia em tempo real. O vídeo de apresentação do Sistema Sillicon, de $1985^{126}$, comenta: "the benchmark is always the same: the fastest most intuitive design becomes the industry standard design. Once your users, or your competitor users have experienced real time response they'll not settle easily to lesser productivety"127, ou seja, uma vez que se experimenta um sistema mais intuitivo e que opera em tempo real, este se torna um padrão de produtividade. Mesmo com a compra da estação Sillicon Graphics (que custou US\$ 75.000 com o sistema francês TDI ${ }^{128}$ Explore), a Vetor não substituiu o Cubicomp e o Amiga de imediato: eles continuaram ativos, operados pelo pessoal que passou a integrar sua equipe fixa da a partir dos anos 90.

Em relação à mão de obra, a Vetor Zero e a Trattoria di Frame compunham suas equipes de formas diferentes. A equipe da Trattoria di Frame contou com animadores 2D e

\footnotetext{
${ }^{124}$ Representação visual de um objeto em 3D em que não aparecem as suas superfícies, apenas as arestas que o compõem.

${ }^{125}$ High-end consiste em produção de alta qualidade para TV e cinema, enquanto que o low-end são produções mais baratas, mais voltadas para o mercado de vídeos institucionais.

${ }^{126}$ Disponível no Youtube: https://www.youtube.com/watch?v=9EEY87HAHzk

${ }^{127}$ A referência é sempre a mesma: o design mais rápido e intuitivo torna-se o padrão na indústria do design. Uma vez que o seu usuário, ou o usuário do seu concorrente experimentam resposta em tempo real, eles não aceitarão menor produtividade facilmente. (tradução nossa)

${ }^{128}$ Thomson Digital Image, foi adquirida pela sua rival, a Wavefront, em 1993.
} 
com finalizadores contratados em regime CLT, mas em geral trabalhava-se com freelancers: intervaladores, cleanners, bonequeiros, animadores de stop-motion e especialistas em efeitos. Já na Vetor, a equipe de modelagem, animação e finalização em 3D era contratada em regime CLT. Tempos depois, já ao final dos anos 90, quando da associação com a Lobo, uma produtora de criação/animação em técnicas mistas, outros colaboradores entraram em cena, o que promoveu a variação dos regimes de contratação conforme o trabalho exigisse e a ampliação do escopo oferecido pela Vetor .

A partir do Sillicon, e posteriormente do Flame, a Vetor pôde saltar para a posição de produtora high-end, passando a ser referência na produção de animação de $3 \mathrm{D}$, de efeitos especiais e também de finalização. Não é arriscado comentar que a expertise desenvolvida na Vetor é em grande parte responsável por uma mudança no modo de se apreciar a computação gráfica. O caso do comercial para o Banespa (fig. 14), em que uma nota de dinheiro "dorme" numa cama e respira e se vira, ilustra o conceito que se tinha a respeito da técnica:

[...] a agência não sabia como fazer isso; então o Wellington ${ }^{129}$, falou: 'Vamos fazer em computação gráfica!'

E os caras: 'não, nem fodendo, é frio, brega, metálico'.

E ele: 'Não, eu conheço os caras que fazem legal".

E os caras: 'não, pelo amor de Deus, não vamos fazer não com computação gráfica, vamos fazer com uma nota de borracha, com fio'.

Ele: 'Esquece, o único jeito de fazer esse filme é com computação gráfica'.

E os caras: 'você banca e afirma que vai ficar bom?'

Ele: 'afirmo'.

[...] E aí a gente fez o trabalho, a agência adorou e foi um puta sucesso. (informação verbal) ${ }^{130 .}$

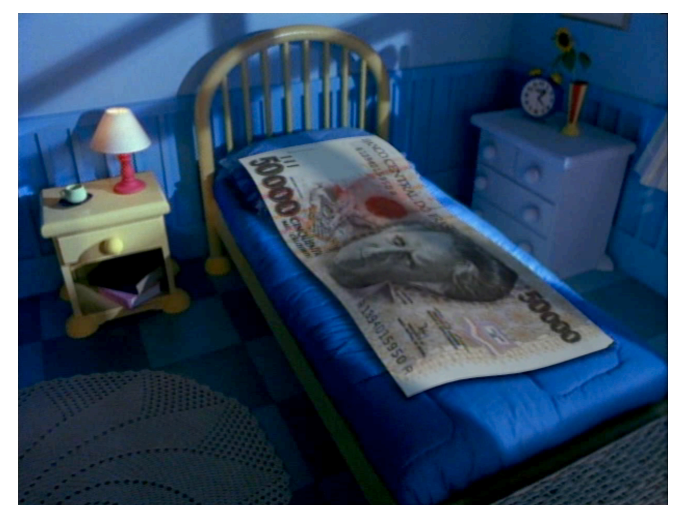

Figura 14 - imagem do comercial do Banespa.

Este foi o primeiro filme em que o 3D justapõe-se à uma imagem real de maneira satisfatória na publicidade brasileira. Com o personagem em 3D aplicado em um cenário real

\footnotetext{
${ }^{129}$ Wellington Amaral, dono da produtora 5.6, diretor de importantes filmes publicitários. É considerado por Alceu Baptista o segundo padrinho da Vetor Zero, depois de Cauby Sampaio do Monte, citado na pg.77.

${ }^{130}$ Entrevista concedida por BAPTISTA, Alceu. Entrevista V. [out. 2013] São Paulo. Entrevistador: Maria Luiza Dias de Almeida Marques. 2013. A entrevista na íntegra encontra-se transcrita no Apêndice E desta monografia.
} 
captado em película, o resultado foge à estética lisa e metálica vigente à época, pois o volume, a textura, a sombra e os movimentos são orgânicos e integrados ao conjunto do filme. É também da Vetor a criação da primeira figura humana em 3D no Brasil, um astronauta (fig. 15) para um comercial da revista Super Interessante, em que Alceu gozou de ampla liberdade de criação.

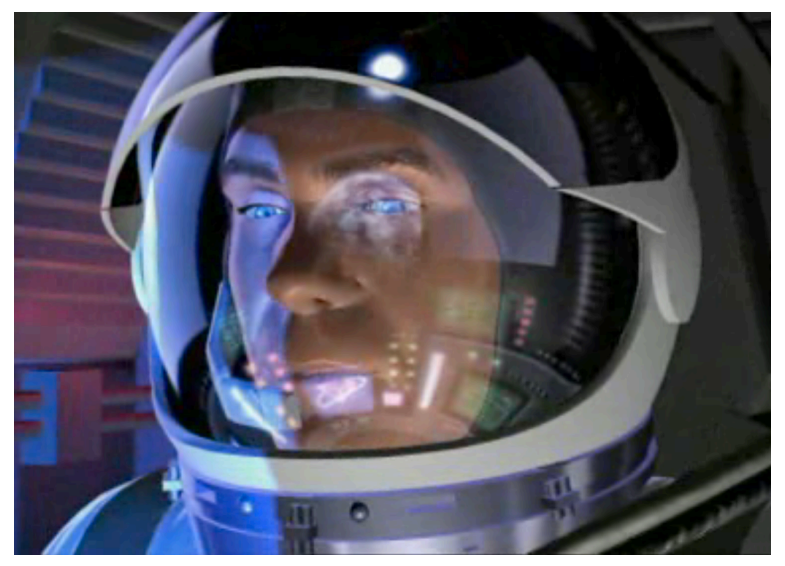

Figura 15 - imagem do filme Superinteressante.

Eu coloquei ali tudo que eu gostava: quadro de Magritte [...], uma baleia debaixo d'água, um astronauta em $3 \mathrm{D}$ e foi a $1^{\mathrm{a}}$ figura humana feita no Brasil. Veja: para essa figura humana, no sistema, ele não aceitava auto shadow; um objeto projetava a sombra no outro, mas o mesmo objeto não projetava a sombra em sim mesmo, então o nariz do astronauta não projetava a sombra no rosto, e para fazer as narinas não ficarem brancas, eu tive que usar duas luzinhas negativas dentro do nariz, coisa que só é possível em computador, luz negativa. Era uma luz que projetava escuro, dentro da narina para que não ficasse branco. Muitas figuras humanas rudimentares da época, tinham as narinas brancas, e as pessoas não se ligavam que era um defeito inaceitável; mas a gente conseguiu fazer e o astronauta foi um sucesso no Brasil. (informação verbal) ${ }^{131}$

Ficou evidente uma característica comum entre as produtoras erigidas em plataforma digital: o investimento constante em equipamentos, em pesquisa e em pessoal. Esta preocupação, com todos os riscos a que se sujeitam, foi crucial na viabilidade e no crescimento das produtoras. À medida em que as produções se sofisticavam, a necessidade por imagens surpreendentes e rapidez nas soluções justificavam a busca pela inovação através da pesquisa, da parceria com novos talentos e da aquisição de equipamentos de ponta.

Nesse sentido, era impositivo que a compra de softwares e equipamentos estivesse prevista no cálculo dos orçamentos. Além disso, a valorização da equipe criativa garantia a manutenção de uma mão de obra altamente especializada, numa época em que era mais raro

${ }^{131} I d, 2013$, p. 19. 
encontrar um profissional de artes familiarizado com as novas tecnologias. A questão do orçamento surgiu, pois, atrelada à estratégia de crescimento das empresas e também como um fator de identificação do seu perfil empresarial, do lugar que ocupa no mercado.

$\mathrm{Eu}$, eu sempre cuidei dos orçamentos, no início da Trattoria até mais ou menos metade da vida, os primeiros 6, 7 anos da Trattoria. Era assim: a gente sabia que a gente operava com um custo que era infinitamente menor do que o dos concorrentes, então, poderia trabalhar com uma margem de lucro bastante grande, porque a gente oferecia uma solução tecnológica bastante diferenciada, e praticamente ninguém mais oferecia isso. Boa parte da grana era pra turma que trabalhava; parte da grana era reinvestida em equipamento. Às vezes a gente pegava um trabalho e dizia assim: 'esse trabalho vai pagar um computador novo; esse trabalho vai dar de lucro uma impressora boa; esse trabalho vai dar de lucro uma beta-cam'... eram os critérios de orçamento. Então, a gente tinha uma grande possibilidade de realizar, era bastante rentável o negócio. [...] Como a gente não tinha um capital externo, tudo era reinvestido na própria empresa e também nos próprios filmes. (informação verbal) ${ }^{132}$

Assim, Carvalho conjectura que os dois aspectos inovadores na gestão da empresa, na prática, contribuíam para a complexidade do cálculo do valor dos filmes: o fato de operar como um coletivo, de buscar a horizontalidade (pelo menos no início) e o reinvestimento na própria empresa. Embora não se lembre com precisão, ele afirma que o percentual distribuído entre os colaboradores era alto e que houve momentos em que 10 ou 15 artistas encontravamse envolvidos em algum projeto na casa. Entre esses, o modelo de contratação CLT não se aplicava, sendo necessário que cada colaborador montasse uma microempresa, para que houvesse uma contratação de prestação de serviços entre empresas - o que reduziria o volume de impostos.

Acerca dos orçamentos, Baptista (cujo sócio é o responsável pelos orçamentos), critica a estratégia-padrão do custo por segundo e indica prazo versus complexidade como elementos fundamentais envolvidos no cálculo:

Orçamento de trabalho, na época havia um mito de que era por segundo, mas não é; eu trabalho em função de uma estimativa de prazo, de tempo que você ia gastar fazendo. Não vou dizer que era um chute, era um chute bem assim elaborado: 'isso aqui vai dar muito trabalho e vai custar $\mathrm{X}$ '. E tinha que negociar com o cliente. Agora, havia empresa que cobrava por segundo, havia um mito sim, de que eram US\$ 500 por segundo. Um segundo de bolinha pulando, era mais difícil do que um segundo de espaçonave passando, então, esse negócio de por segundo era muito duvidoso. (informação verbal) ${ }^{133}$

\footnotetext{
${ }^{132}$ Entrevista concedida por CARVALHO, Guto. Entrevista IV. [set. 2013] São Paulo. Entrevistador: Maria Luiza Dias de Almeida Marques. 2013. A entrevista na íntegra encontra-se transcrita no Apêndice D desta monografia.

${ }^{133}$ Entrevista concedida por BAPTISTA, Alceu. Entrevista V. [out. 2013] São Paulo. Entrevistador: Maria Luiza Dias de Almeida Marques. 2013. A entrevista na íntegra encontra-se transcrita no Apêndice E desta monografia.
} 
A velocidade do aprimoramento dos hardwares e softwares na década de 90 seguiu em ritmo alucinante rumo à convergência das mídias. Isto significa que, se num primeiro momento a computação e a película não se conversavam, ou o custo disto era altíssimo, na sequência dos anos a digitalização do material analógico e as conversões entre diferentes formatos baratearam e se simplificaram. Além disso, democratizou-se o acesso e diversificaram-se as possibilidades de miscelânea técnica. Paralelamente, a tecnologia da captação digital de imagem correu a passos largos trazendo ao vídeo e à fotografia digital uma qualidade mais próxima à da película.

Guto Carvalho, que redescobriu a película através dos meios digitais, relatou uma passagem interessante a respeito da fotografia digital que, no início dos anos 90, era completamente desacreditada por não apresentar uma resolução compatível com a qualidade de impressão exigida nos meios de comunicação. Apresentada pela Kodak em uma editoria de imagem de um grande jornal, a câmera digital foi imediatamente descartada por apresentar apenas 640x480 de resolução, o padrão vídeo:

Em 1992, [...] a gente queria fazer um filme; a gente foi lá e pediu emprestado a câmera da Kodak, a primeira câmera digital que tinha no Brasil. Não a primeira assim, veja bem, tecnologia, os milicos já tinham... a medicina também, mas a primeira voltada pra área de comunicação. A gente fez com uma câmera [fotográfica] digital o primeiro filme em stop motion digital, em 1992. Era um filme de Credicard, com a W/Brasil, umas animaçõezinhas. Talvez um dos primeiros stop-motion digital do mundo... Porque não existiam câmeras digitais, e a maior parte das câmeras digitais não estavam com animadores. Pra fazer um filme, que tem resolução $640 \mathrm{x}$ 480, na época, isso era muito boa essa resolução, era o padrão broad-casting. Era mais do que suficiente, então, a gente batia a foto, uma a uma e fazia uma animação, um stop-motion. Isso num tempo em que fazer stop-motion era uma loucura. Ninguém fazia stop-motion porque era muito complexo. Foi antes do [Fernando] Coster fazer o filme dele. Tempos depois a gente concluiu que uma câmera de cinema fazia isso muito bem de uma maneira bem barata, ficamos com a câmera de cinema fazendo isso durante um tempo, mas logo depois trabalhávamos com uma câmera de cinema junto com uma câmera digital, e o cliente não conseguiu distinguir o que era película do que era digital. (informação verbal) ${ }^{134}$

Também houve impacto da evolução digital na finalização dos filmes em relação à composição de imagens geradas por diferentes fontes - computador, película, vídeo, fotografia - a sonorização e a entrega em determinada mídia. Esses processos que normalmente eram realizados em produtoras de finalização passaram a ser executados nas próprias produtoras.

\footnotetext{
${ }^{134}$ Entrevista concedida por CARVALHO, Guto. Entrevista IV. [set. 2013] São Paulo. Entrevistador: Maria Luiza Dias de Almeida Marques. 2013. A entrevista na íntegra encontra-se transcrita no Apêndice D desta monografia.
} 
Dentre os processos que precedem a entrega do filme, a inserção do som sempre foi e continuou sendo um elemento externo às produtoras, normalmente havendo uma produtora de som/trilhas. A linha de produção na publicidade sempre contou com uma produtora de som externa, com a qual se poderia ou não trabalhar em parceria, mas que, muitas vezes, era indicada pela agência pois encarregava-se também do spot para veiculação em rádio. Um filme de publicidade era, pois, uma peça dentro de uma campanha multimídia, que incluía rádio, jornal, revista e TV, ou seja, a peça de TV tinha que estar alinhada com as outras mídias. Em alguns casos, as animações eram entregues ao cliente que se encarregava de sonorizar, sem que a versão final do filme saísse da produtora.

Finalizando, a mídia na qual os trabalhos eram entregues até meados da década de 1990 o padrão broad-cast de então, era a fita Beta-Cam, analógica ou digital. O computador descarregava o trabalho pronto diretamente na fita, em tempo real.

Do lento processo descrito por Baptista para descarregar as animações em fita UMatic, à completa integração entre o digital e o analógico, assiste-se a uma apropriação gradual de todas as fases da linha de produção em animação e efeitos, numa época em que a animação publicitária ganhou novas ferramentas - o que, na visão dos entrevistados, paradoxalmente não resultou necessariamente num aporte criativo proporcional. Os motivos que levaram a esta percepção relacionam-se, de certa forma, a uma resistência à experimentação por parte de agências e clientes e à adesão a fórmulas já testadas no mercado internacional, por parte das agências. $\mathrm{O}$ alto investimento em espaço de mídia e a necessidade da inteligibilidade em todos os estratos da sociedade acabam por limitar propostas de linguagem mais arrojadas que se beneficiariam de todo um arsenal tecnológico voltado para desenvolvimento de imagens em movimento. Mas a partir daí, entendemos tratar-se de um tema que engendraria um novo projeto de pesquisa. 


\section{Considerações Finais}

Visitar a trajetória do cinema de animação brasileiro, identificar seus atores e localizar pontos de inflexão ocasionados por avanços tecnológicos é uma tarefa multifacetada e com diferentes formas de abordagem. Nesta pesquisa, norteada pela compreensão das implicações da evolução tecnológica, foi possível avaliar o modo como as invenções voltadas para a animação, especificamente as ferramentas digitais, afetaram o fluxo de trabalho e promoveram transformações qualitativas no produto final. Trata-se portanto de um trabalho que procurou colaborar com a construção de um acervo de informações sobre animação aproveitando a disponibilidade, a memória e o repertório de personagens centrais do processo de transição do modo de produção analógico para o digital. Nesse sentido, a seleção de entrevistados desta pesquisa contou com personalidades inquietas e incansáveis na busca por um resultado imaginado e na transposição das barreiras técnicas.

A partir da pesquisa bibliográfica, pode-se observar a falta de livros de referência sobre o desenvolvimento da animação no Brasil, carência essa que se encontra também em importantes arquivos como a Cinemateca Brasileira. Exceção a se saudar é a obra de Antonio Moreno, "A Experiência Brasileira do Cinema de Animação", de 1978, um inventário cronológico dessa produção brasileira. Moreno preocupa-se em questionar a posição marginal ocupada por nossa animação, creditando à falta de investimentos e de proteção estatal o nosso atraso na área, o que não diminuiria, segundo ele, o potencial criativo dos animadores brasileiros. Ao final, ele nos brinda com depoimentos de Roberto Miller, Marcos Magalhães e Still (Pedro Ernesto Stilpen), animadores independentes, que contam um pouco do significado da escolha pela animação em suas trajetórias.

Somando-se a este quadro, poucos filmes representativos do início da animação no Brasil sobreviveram, restando ao pesquisador conjecturar a respeito de todo um contexto de produção de tempos idos. Constata-se, pois, que há um período de cerca de 40 anos, de 1907 até a meados da década de 50, em que a maior parte dos filmes extraviou-se sem que deles se tenham sequer fotografias, boletins de produção ou qualquer outro material que indique seu processo de produção.

A inclusão dos estúdios Vetor Zero e o de Daniel Messias, no decorrer da pesquisa, deu-se ao percebermos que o exame dos outros três estúdios, inicialmente proposto, resultaria em uma amostragem insuficiente para representar todo um conjunto de transformações em curso. Confirmou-se a importância dessa inclusão após realizadas as entrevistas, dado o volume de informações novas e conexões extras que proporcionaram, servindo à ampliação 
do mapa de investigações. É importante salientar que as contribuições dos entrevistados não se restringiram às respostas e aos relatos de suas memórias, vindo mesmo a contribuir na reflexão que orientou estas considerações finais.

Nesta pesquisa foram utilizados três indicadores gerais que permitiram identificar os reflexos da implementação da tecnologia digital no setor da animação publicitária: 1) a estrutura empresarial, 2) o fluxo de trabalho, e 3) as características visuais dos filmes. Estrutura empresarial engloba as informações relativas à equipe e aos orçamentos; por fluxo de trabalho, entende-se o relacionamento com as agências para criação e layout dos filmes e a animação propriamente dita. As características visuais concernem ao tipo de animação: se é 2D, 3D, stop-motion, efeitos na mesa de trucagem ou no computador, combinação de animação com imagem ao vivo, finalização, textura, ou seja, tudo o que se relaciona com o aspecto plástico dos filmes.

Para introduzir estes temas, escolhemos abordar o "background" cultural de cada um dos entrevistados e sua influência ou relação com os trabalhos que viriam a ser produzidos. Escolhi trechos significativos das entrevistas que apontam para as tendências de cada realizador.

Como motivação para o ofício de profissional da animação ${ }^{135}$, todos os entrevistados comungam do interesse pelo desenho, cartoon e cinema desde a infância. O ideal estético de Joaquim Três Rios, o mais velho de todos, refletiu o encantamento que teve ao assistir Branca de Neve:

Eu devia ter entre 4 e 5 anos. [...] Me lembro bem que um dia meu pai chegou em casa e falou de um americano que fez um filme, me lembro bem, parece que estou vendo meu pai entrar em casa, um americano tinha feito um filme de longa-metragem, tudo em desenho animado. Eu não sabia o que era desenho animado, não sabia nem o que era um filme. Tinha visto alguns filminhos: eu tinha um tio que tinha uma maquininha, uma Pathé-Baby. [...] E fomos ao cinema. E quando nós chegamos ao cinema, a rua era um tormento, tinha gente prá todo lado, uma fila desorganizada, um empurraempurra, meu pai dizia: 'vou lá na porta do cinema ver o que está acontecendo'. E ele voltou dizendo: 'não, não vamos entrar, vamos prá casa'. E não fomos ao cinema naquele dia, estava lotado. Fomos num outro dia. [...] Eu tenho medo da bruxa até hoje, fiquei apavorado com aquela bruxa; adorei o filme, adorei aquela cor, ficou marcado em mim. (informação verbal $)^{136}$

\footnotetext{
${ }^{135}$ Guto Carvalho é o único dos entrevistados que não é animador: é diretor de filmes ao vivo e de animação.

${ }^{136}$ Entrevista concedida por TRÊS RIOS, Joaquim. Entrevista I. [out. 2012] São Paulo. Entrevistador: Maria

Luiza Dias de Almeida Marques. 2012. A entrevista na íntegra encontra-se transcrita no Apêndice A desta monografia.
} 
Naturalmente, com o decorrer dos anos e aquisição de outras referências, o trabalho de Joaquim foi permeado pela estética corrente no cinema e na televisão nas diferentes épocas, como por exemplo as influências de Saul Bass nos anos 60 e Bob Abel nos anos 70.

Walbercy Ribas, criado em fazenda, encantava-se com os valores universais e com a estética da animação do Leste Europeu:

Eu tinha uma inquietude natural, eu queria fazer animação revolucionária, eu não gosto de animação quadradinha, aquelas animações que tinha na época; Pica-Pau, Tom e Jerry, eu odiava, né, embora eu goste do Tom e Jerry, eu acho maravilhoso, Pica-Pau, eu já achava meio... e eu acompanhava as animações americanas da UPA, que fazia aquela coisa... o grupo que saiu da Disney, prá revolucionar a animação nos EUA. Só que a animação que mais me influenciou foi animação da antiga Iuguslávia, e, acho que onde hoje é a Sérvia, e a República Tcheca. Eu me identificava demais com aqueles trabalhos; eu gostava muito do Dusan Vukotic, que era um diretor iuguslavo espetacular; eu também gostava muito do Karel Zeman, que não era animador, mas era um diretor de filmes ao vivo, mas que fazia verdadeiras loucuras. Tinha o Jri Trnka, com as animações de quadro-a-quadro, que era um gênio... (informação verbal) ${ }^{137}$

Walbercy foi provavelmente um dos diretores que mais soube infiltrar sua personalidade e seu estilo na publicidade, levando aos comerciais de Sharp e Etapa, entre outros, um trabalho fortemente autoral, com viés surrealista.

Já Daniel Messias, filho de cartunista e excelente desenhista, expressou suas preferências:

Eu gostava muito mais do cinema de deboche, do cartoon, aquela coisa mais hard core, desenhos, por exemplo da Metro, do Tom \& Jerry, mais do que dos desenhos da Disney, que eu já achava muito infantis, claro, eu não era mais criança, mas eu perdi o interesse pela Disney cedo, sabe? Fiquei encantado pela charge. Porque o ambiente que eu frequentava era um ambiente assim, de pessoas como chargistas, de deboche, do politicamente incorreto, a turma brincava muito... e eu adorava viver nesse universo. Isso teve muita influência sobre mim. (informação verbal) ${ }^{138}$

É nítido o contraste entre as preferências de Daniel Messias e de Walbercy Ribas. De um lado, as questões que afetam a existência humana, presentes nos filmes iuguslavos, tão caras a Walbercy, de outro, o gosto de Messias pelo humor sarcástico e pelo atrevimento das produções da UPA e da Metro. Curiosamente, essas diferenças, como mencionado, também se estampam no relacionamento entre os dois profissionais.

A motivação artística de Alceu Batista, por outro lado, passou pelo desejo de ter

\footnotetext{
${ }^{137}$ Entrevista concedida por RIBAS, Walbercy. Entrevista II. [ago. 2013] São Paulo. Entrevistador: Maria Luiza Dias de Almeida Marques. 2013. A entrevista na íntegra encontra-se transcrita no Apêndice B desta monografia. ${ }^{138}$ Entrevista concedida por MESSIAS, Daniel. Entrevista III. [jan. 2013] São Paulo. Entrevistador: Maria Luiza Dias de Almeida Marques. 2013. A entrevista na íntegra encontra-se transcrita no Apêndice C desta monografia.
} 
equipamentos eletrônicos que, em sua infância humilde, ele nunca conseguiria adquirir de outra forma, a não ser, construindo ele mesmo. Já na Escola Politécnica da USP, percebendo a impossibilidade de materializar seus anseios, pulou para a Escola de Comunicações e Artes, onde o contato com o pessoal do teatro e do cinema abriu novas possibilidades. Sua aptidão para desenho levou-o a trabalhar com ilustração realista e o poderoso visual de Star Wars foi determinante em seu interesse por tecnologia e nas conquistas ligadas à computação gráfica.

Eu gostava de ilustrar, trabalhava para revista e editorial; mas só depois da ECA, eu comecei a trabalhar mesmo com isso, e comecei a tentar me meter trabalhar com efeitos especiais. Durante o curso da ECA eu construí uma espaçonave. Não cheguei acabar, mas foi feita para matérias do currículo, matérias um pouco mais abertas que você tinha meio que, você podia escolher o que você queria fazer e alguns professores foram bastante flexíveis comigo e me permitiram construir uma espaçonave, e eu fiquei meio famoso na ECA por conta dessas loucuras que eu fazia. (informação verbal) ${ }^{139}$

A entrada de Alceu na publicidade deu-se antes pela porta dos efeitos especiais do que pela animação propriamente dita.

Guto Carvalho, o único da pesquisa que não é desenhista ou animador, mas que enveredou pela animação por um aguçado senso de oportunidade, é o que possui a formação mais eclética de todos, unindo dança, física e pedagogia em sua pesquisa pessoal em busca da representação do movimento.

[...] eu me defino como uma pessoa muito preocupada com a questão da educação, do conhecimento e da transmissão do conhecimento. Talvez já seja de uma primeira geração em que as inspirações vieram multi-facetadas." (informação verbal) ${ }^{140}$

A pesquisa de Guto Carvalho durante o período em que trabalhou com animação corresponde à busca pela adequação da linguagem à mensagem, o que na prática resultou na miscelânea de materiais (físicos) e de técnicas, num período em que o diálogo com as agências/clientes era bilateral, ou seja, as propostas de direção vindas das produtoras tinham um peso maior na composição final de um filme.

Estrutura empresarial: equipe e orçamentos

Em relação ao gerenciamento dos estúdios, manteve-se o modelo de planejamento dos

\footnotetext{
${ }^{139}$ Entrevista concedida por BAPTISTA, Alceu. Entrevista V. [out. 2013] São Paulo. Entrevistador: Maria Luiza Dias de Almeida Marques. 2013. A entrevista na íntegra encontra-se transcrita no Apêndice E desta monografia.

${ }^{140}$ Entrevista concedida por CARVALHO, Guto. Entrevista IV. [set. 2013] São Paulo. Entrevistador: Maria Luiza Dias de Almeida Marques. 2013. A entrevista na íntegra encontra-se transcrita no Apêndice D desta monografia.
} 
filmes, coordenação, direção artística, as decisões técnicas da época prévia aos computadores: os proprietários continuaram na condução das atividades vitais da empresa. Isso significa que se o filme vai ser feito em Toon-Boom ou em animação tradicional, ainda é o diretor quem decide.

Mais ou menos, de 1978 a 1988 , ou até 1990 , até a entrada do Collor,
quando o Collor entrou a miséria se estabeleceu. [...] até então os filmes
eram muito bem pagos, dava gosto de trabalhar, porque, quer queira, quer
não queira, no mundo capitalista o que fala mais é o capital, se você não tem
dinheiro prá trabalhar, você não paga nada, não paga dívida.... Então eu acho
que eu me identifiquei bastante nessa fase, até os anos 90 , depois, as coisas
começaram a cair, mas, depois que o Collor entrou foi um arraso total.
Realmente as coisas mudaram, e foi quando começou a entrar o vídeo.
(informação verbal)

Walbercy Ribas sintetiza, no parágrafo acima, sua percepção do rumo que tomou o métier do qual foi um dos protagonistas durante quase duas décadas. Seu discurso e o de Daniel Messias combinam na observação das mudanças no fluxo de trabalho, o workflow.

O cálculo dos orçamentos, vital em qualquer empresa, altera-se, com o advento da computação, não da forma imaginada, com a baixa dos custos de produção, mas com a baixa do valor que o mercado estava disposto a pagar. Empresas de grande porte tornaram-se cada vez mais difíceis de se manter. $\mathrm{O}$ que os relatos trouxeram é que os filmes de padrão publicitário continuam tendo seu preço alto, calculado pelo tempo de envolvimento com cada projeto. Mão de obra, equipamentos, insumos e custo fixo (como aluguel do imóvel, impostos) sofreram poucas alterações de valor. A diminuição do número de funcionários não trouxe necessariamente a diminuição direta na folha de pagamentos, pois, sendo mais especializados, seu custo era mais elevado. Com o passar dos anos e com a "alfabetização digital" mais generalizada, o valor da mão de obra tendeu a cair. Contudo, os profissionais com expertise, capacitados para criação, mais raros, mantiveram seu valor.

Os funcionários contratados - para filetagem e coloristas - deram lugar aos freelancers, o que não agradava muito a Walbercy e a Messias. Para eles, o freelancer não tem a identidade da produtora. Pode trazer experiências diferentes, mas passa pelo trabalho de ser "moldado" para cada estúdio. De acordo com eles, esse contingente especializado no trato com o acetato em parte migrou para o trabalho digital, em parte evadiu da animação.

Se o custo com acetatos, tinta, truca e película deixaram de existir, o investimento em equipamentos de ponta sempre foi caro, sobretudo pelos impostos de importação. Num

\footnotetext{
${ }^{141}$ Entrevista concedida por RIBAS, Walbercy. Entrevista II. [ago. 2013] São Paulo. Entrevistador: Maria Luiza Dias de Almeida Marques. 2013. A entrevista na íntegra encontra-se transcrita no Apêndice B desta monografia.
} 
primeiro momento, o final dos anos 80 e início dos 90, o acesso a computadores para vídeo e animação ainda dependia de um bom montante de capital inicial para quem se aventurasse a produzir. A redução dos valores, tendência observada com o passar dos anos, trouxe a democratização da possibilidade de se trabalhar, aumentou a competitividade, o que no mercado também incidiu na queda do preço a que se dispõem pagar os clientes. Observou-se, na apreciação de filmes inaugurais da Trattoria e da Vetor, uma certa adequação da expressão aos novos meios, ou seja, a tentativa de se representar algo com o recurso disponível. Baptista realçou ter ocorrido logo no início da computação gráfica no Brasil uma tendência à simplificação estética no design e na animação, o que se exemplifica em filmes como Olla, de Guto Carvalho e em vinhetas animadas com os flying logos. No exemplo de Olla, ciclos de ilustrações criadas no Illustrator são colocados em sequência, gerando uma animação simplória, embora bastante criativa. Filmes como este e vinhetas de letreiros metálicos voadores, etc., causavam uma impressão distorcida de que tudo o que é feito no computador é fácil: basta-se ter um computador para fazer animação. Os orçamentos sofreram desvalorização, muito mais por conta desta mentalidade do que pela suposta diminuição de trabalho na execução dos filmes, além do aumento da concorrência.

Vê-se, ao final deste processo, a pulverização das grandes produtoras dos anos 70 e 80 e o surgimento de pequenos negócios. A estrutura de produção no modo de produção analógico não resistiu ao ganho de agilidade no processo produtivo, a toda uma mudança na forma de apreciação da animação e também a uma legislação trabalhista mal formulada para o trabalho em cinema e vídeo, que não atende mais à nova ordem implantada.

Observando, portanto, o entusiasmo que a computação causou em Walbercy Ribas e Daniel Messias, não é exagero supor que o redirecionamento em suas carreiras, a partir de meados dos anos 90, relaciona-se mais com um desgaste natural da vontade criativa, uma saturação em se fazer mais do mesmo, do que propriamente à chegada dos computadores:

[...] eu acho que o desenho animado se desprestigiou completamente; hoje qualquer coisa é desenho animado. Hoje, a animação feita na computação gráfica é tão boa, ou melhor do que a feita à mão. Por quê? Só o fato de você poder fazer um ambiente se movimentar, você trabalhar com luz, sombra, coisas que eram impossíveis na mão, só isso já deu um elemento fantástico, não? mas o cliente quer umas coisas mais assim... é conservador, quer tudo bonitinho, quer que, desde o favelado até o rico, que ele entenda. Então, você deixa de experimentar, deixa de avançar. Essa fase dos anos 70 até os anos 90 foram os anos mais lindos na publicidade brasileira. Depois, pifou. Parece que apagaram as luzinhas, muitos pararam, muitos morreram, muitos abandonaram, foram fazer outra coisa. (informação verbal) ${ }^{142}$

\footnotetext{
${ }^{142}$ Entrevista concedida por RIBAS, Walbercy. Entrevista II. [ago. 2013] São Paulo. Entrevistador: Maria Luiza Dias de Almeida Marques. 2013. A entrevista na íntegra encontra-se transcrita no Apêndice B desta monografia.
} 
No período de análise das entrevistas, percebemos ser inviável dissociar a situação interna dos estúdios com a situação político-econômica e cultural no Brasil. O período estudado coincidiu com um momento em que produzir cinema ou animação no Brasil era visto como uma atividade sem perspectiva sob os aspectos competitivo e econômico, e sem condição de se estabelecer com periodicidade para a formação de um público cativo, enfim, uma atividade sem prestígio, de um modo geral.

No cinema publicitário, o quadro é diferente, pois há muitos mais recursos disponíveis, mas nem por isso é imune aos efeitos da situação econômica do país. A entrevista com Joaquim Três Rios, foi aquela que trouxe de maneira mais intensa a consequência do Plano Collor, fazendo-nos incluir nas demais entrevistas uma pergunta a respeito da reação a este plano econômico. A estabilização da economia vinda com o Plano Real, por sua vez, representou um ambiente propício ao desenvolvimento das novas produtoras.

Foi possível observar, pois, que a computação não interfere por si só, isoladamente no meio da animação. Ela atua em conjunto com fatores econômicos, sociais e culturais. Cada um dos entrevistados trouxe memórias detalhadas da superação deste momento. Na história de Joaquim Três Rios, por exemplo, o plano foi relembrado como o "uma bala na testa", como o fator crucial para o fim das operações de sua empresa, com a demissão de todos os funcionários:

[...] os clientes ligavam e diziam: 'Pára tudo!'; equipe de produção da Sales, imagina. Refinações de milho Brasil, nós já tínhamos feito 5 filmes pra eles, a série ia continuar, tinha umas trucagens complicadas que a gente ia fazer em Miami; orçando o filme, pronto prá começar a produzir. (informação verbal) ${ }^{143}$

Walbercy Ribas, com uma carteira de clientes mais variada e introduzindo a computação na empresa, reinventou-se, diminuiu equipe e "administrou a miséria", para manter-se ativo:

Quando o Collor entrou foi um arraso total. Realmente as coisas mudaram, e foi quando começou a entrar o vídeo. [...] Mandei 15 embora, na hora. Isso foi bem violento. A entrada do Collor foi um outro divisor de águas na propaganda. Enfraqueceu muita gente, muita gente morreu de enfarto, derrame. Muita gente perdeu tudo que tinha. (informação verbal) ${ }^{144}$

Já Daniel Messias contou que não sofreu muito com o plano e que a política econômica desastrosa do governo Collor foi inspiração para um trabalho autoral:

Eu nunca consegui acumulação. Formar um capital de reserva, balela. O

\footnotetext{
${ }^{143}$ Entrevista concedida por TRÊS RIOS, Joaquim. Entrevista I. [out. 2012] São Paulo. Entrevistador: Maria Luiza Dias de Almeida Marques. 2012. A entrevista na íntegra encontra-se transcrita no Apêndice A desta monografia.

${ }^{144}$ Entrevista concedida por RIBAS, Walbercy. Entrevista II. [ago. 2013] São Paulo. Entrevistador: Maria Luiza Dias de Almeida Marques. 2013. A entrevista na íntegra encontra-se transcrita no Apêndice B desta monografia.
} 
dinheiro entrava, saía. A gente tinha que manter a coisa funcionando através do trabalho. Eu não perdi nada porque eu não tinha nada.[...] eu deveria até agradecer o Collor, porque eu acabei fazendo um curta-metragem Dinda's, que acabou ganhando um prêmio em Cuba. (informação verbal) ${ }^{145}$

Empresas jovens, a Vetor Zero e a Trattoria di Frame investiam praticamente todo o dinheiro que entrava em equipamentos e não possuíam uma reserva de capital. Com equipes pequenas (praticamente os sócios e um ou dois colaboradores externos), sofreram menos negativamente o impacto do Plano Collor do que os outros estúdios. Já para Alceu Baptista uma das consequências foi que:

[...] não tinha mais trabalho. A gente não tinha dinheiro no Banco, a gente não tinha conseguido ganhar dinheiro suficiente para ter uma reserva no Banco ou para ter um caixa grande, nosso caixa era pequeno; então a gente sofreu pouco, assim, a gente não perdeu uma grande quantidade de dinheiro. (informação verbal) ${ }^{146}$

Guto Carvalho emenda e acrescenta uma observação a respeito do Plano Real:

A questão do Collor não nos afetou muito porque a gente não tinha dinheiro na poupança. Mas, nessa linha de conjunturas externas, pelo contrário, a gente viu que, logo em seguida do Collor, veio o FHC e trouxe o Plano Real. Então, sim, o Plano Real foi fundamental, porque quando a gente fazia os orçamentos, tinha que lidar com uma inflação estúpida de $20 \%$ ao mês. Então, o orçamento tinha que prever isso, era uma manobra financeira muito grande. Eu me lembro claramente do alívio que foi quando estabilizou, a questão da coisa e a gente podia fazer orçamentos mais realistas, mais fáceis de serem seguidos. Isso foi, pra gente, que estava começando, um ambiente muito propício. O Plano Real foi logo no segundo ou terceiro ano da Trattoria. Eu me lembro que a gente pensou 'nossa, agora eu posso finalmente planejar e cumprir um orçamento', sem o componente inflacionário, que é terrível pra gente. (informação verbal) ${ }^{147}$

A respeito da animação como negócio, Daniel Messias finaliza:

Se alguém quer ganhar dinheiro, eu aconselharia realmente um outro negócio, porque animação é um processo lento, demorado, e no final não é tão lucrativo como encher linguiça. Eu tenho um amigo que o negócio dele era fibras de linguiça e ele ficou arquimilhonário! Mas animação é prá quem gosta realmente. Quem gosta, não mede essas coisas. Faz o projeto: tem prejuízo em um, compensa no outro... e vai tocando a vida. (informação verbal $^{148}$

\footnotetext{
${ }^{145}$ Entrevista concedida por MESSIAS, Daniel. Entrevista III. [jan. 2013] São Paulo. Entrevistador: Maria Luiza Dias de Almeida Marques. 2013. A entrevista na íntegra encontra-se transcrita no Apêndice C desta monografia.

${ }^{146}$ Entrevista concedida por BAPTISTA, Alceu. Entrevista V. [out. 2013] São Paulo. Entrevistador: Maria Luiza Dias de Almeida Marques. 2013. A entrevista na íntegra encontra-se transcrita no Apêndice E desta monografia.

${ }^{147}$ Entrevista concedida por CARVALHO, Guto. Entrevista IV. [set. 2013] São Paulo. Entrevistador: Maria Luiza Dias de Almeida Marques. 2013. A entrevista na íntegra encontra-se transcrita no Apêndice D desta monografia.

${ }^{148}$ Entrevista concedida por MESSIAS, Daniel. Entrevista III. [jan. 2013] São Paulo. Entrevistador: Maria Luiza Dias de Almeida Marques. 2013. A entrevista na íntegra encontra-se transcrita no Apêndice C desta monografia.
} 
Fluxo de Trabalho - relação com as agências para criação e layout dos filmes

O processo de substituição do modelo analógico para o digital iniciado, nos estúdios tradicionais, em 1989, completou-se em 1995, ano em que se lembram de não mais trabalhar com película nem com acetato. Durante este período, a tecnologia representou, por um lado, uma possibilidade real para pequenos novos negócios, a exemplo da Trattoria di Frame e da Vetor Zero. Por outro, levou profissionais estabelecidos, como Joaquim Três Rios, a saírem do mercado.

As implicações deste processo no modo de se conceber e de se apreciar a animação não pouparam nenhum segmento desta cadeia produtiva. Os procedimentos na criação também tiveram de ser repensados, uma vez que todo produto audiovisual ganhou possibilidades estéticas que incluem replicação, combinação e manipulação entre imagens criadas no universo real e no digital:

A habilidade de editar, combinar e reproduzir animação ou live action de maneiras indetectáveis não apenas esfumaça quaisquer distinções entre esses elementos, mas também muda o valor se atribui a cada qual. (DENSLOW, 1997, p. 3)

Assim, foi necessária - e deu-se - uma reeducação do olhar, uma reflexão que abrange, inclusive por parte do público, a questão do modo como se fazem as imagens e os efeitos, o que afetou diretamente a criação. A partir do momento em que a computação é vista como algo que produz tudo sozinha, os departamentos de criação nas agências passaram a elucubrar em voos inalcançáveis, o que na visão de Alceu Batista necessitava ser freado:

[...] você tinha que educar e falar: 'não é bem assim, a gente consegue fazer, mas tudo que você faz em 3D, é solido, não existe manipulação de líquido, tudo é polígono'. Se você tem uma bola, na verdade a bola é uma geodésica. (informação verbal) $^{149}$

Referindo-se à computação gráfica 3D, Alceu complementa que houve dois momentos distintos na forma de recepção destas imagens:

No $1^{\circ}$ momento, todo mundo queria porque era sinônimo de alta tecnologia, então você tinha que, às vezes, trabalhar em baixa resolução para que as pessoas percebessem que era resolução gráfica, pra que não deixasse duvidas que era computação gráfica. E todo mundo passou a querer na época, o que a gente chama de flying logo, logotipo voador para fazer assinatura, metálico, de vidro, etc. [...] E o sonho de todos nós era animar personagem, animar espaçonave, coisas que ainda não dava para fazer na época. $\mathrm{O} 3 \mathrm{D}$ não tinha chegado numa capacidade de realismo, e a gente via gente lá fora fazendo

\footnotetext{
${ }^{149}$ Entrevista concedida por BAPTISTA, Alceu. Entrevista V. [out. 2013] São Paulo. Entrevistador: Maria Luiza Dias de Almeida Marques. 2013. A entrevista na íntegra encontra-se transcrita no Apêndice E desta monografia.
} 
personagem, mesmo que não fosse foto realista, mas era bacana, legal, coisas divertidas e interessantes. E aí, desse $1^{\circ}$ momento de aceitação cega, passou haver uma rejeição dizendo que a computação gráfica era fria, feita por computador, era brega, era metálica, era não sei o quê... (informação verbal $^{150}$

O sucesso de Jurassik Park e Terminator 2 ajudaram a dissolver esta imagem de falta de humanidade e frieza conectados ao 3D, o que representou uma nova fruição estética da computação gráfica.

Embora todos os entrevistados concordem com a ampliação das possibilidades criativas pós-computação, foi comum entre eles a opinião de que os trabalhos tornaram-se aos poucos menos ousados: o que as agências procuram é a segurança, a compreensão em todas as classes sociais e a repetição de algo que já tenha funcionado no exterior. De acordo com Walbercy Ribas,

[...] as agências não estão tão preocupadas com o moderno, elas estão influenciadas pelos festivais. Vai todo mundo fuçar lá no Festival de Cannes. Aí você vê 3,4 filmes no ar, mesma coisa, você pode ver que é sempre depois que vem a temporada de "chupar", de copiar. O departamento criativo fica atento porque ele recebe muitos filmes, mas, o dono da agência não está nenhum pouco interessado com isso. Vanguardistas sempre foram as produtoras. Os produtores sim, estão sempre se comunicando, comprando revista, vendo filme, fazendo pesquisa e vendo o que está acontecendo de todo lado. Ninguém vem [das agências] com uma idéia original falar assim: 'pô, eu tenho uma idéia genial, queria fazer um trabalho assim, assim...' não. Tudo vem assim: 'você lembra aquele filme que fizeram...?' Ou: 'Tem um negócio na internet agora, a gente queria fazer algo semelhante'. Semelhante é chupar, é copiar, não é original, isso que eu acho ruim até hoje.(informação verbal) ${ }^{151}$

Guto Carvalho complementa:

[...] essa época também é uma época muito rica em que o uso dos computadores começou a incorporar uma série incrivelmente diversificada de recursos visuais à produção audiovisual. Coisa que não havia antes. Com o aumento da internet, a popularização e a distribuição dos filmes, essa questão da referência passou a ser de menor importância, muitas vezes aí a agência já fazia suas próprias pesquisas e vinha com seus próprios indicativos de solução, o que pra mim especialmente, foi um retrocesso. (informação verbal) ${ }^{152}$

Mais próximo do fim dos anos 1990, a internet potencializou a revolução digital e

\footnotetext{
${ }^{150} I d ., 2013$, p. 18.

${ }^{151}$ Entrevista concedida por RIBAS, Walbercy. Entrevista II. [ago. 2013] São Paulo. Entrevistador: Maria Luiza Dias de Almeida Marques. 2013. A entrevista na íntegra encontra-se transcrita no Apêndice B desta monografia.

${ }^{152}$ Entrevista concedida por CARVALHO, Guto. Entrevista IV. [set. 2013] São Paulo. Entrevistador: Maria Luiza Dias de Almeida Marques. 2013. A entrevista na íntegra encontra-se transcrita no Apêndice D desta monografia.
} 
deu-lhe nova dimensão, interferindo irreversivelmente na consulta a referências e na proliferação de estilos efêmeros.

\section{$\underline{\text { Fluxo de Trabalho - a animação propriamente dita }}$}

Neste item observaremos, entrelaçando as ópticas dos envolvidos, as transformações entendidas como positivas ou negativas, em relação ao modo de produção analógico. Vale ressaltar que este estudo também prestou-se para conhecer o que pensavam os animadores de sua própria obra, o que se mostrou essencial no entendimento do rumo que tomaram suas carreiras. Se Joaquim Três Rios disse: "isso não vai dar em nada" e Walbercy "graças a Deus que chegou o computador", vale tentar identificar a que exatamente eles se referem, uma vez que, para Joaquim Três Rios, estava em jogo a capacidade do computador de emular o trabalho humano, ao passo que, para Walbercy Ribas, o computador veio para proporcionar voos da imaginação impensáveis para a capacidade manual. Nenhuma destas, pois, é a visão de Daniel Messias, para quem a computação propiciou, sim, a execução de animações impossíveis a mão, mas sobretudo, facilitou tarefas mecânicas rotineiras, como a pintura das imagens; nem de Alceu Baptista e Guto Carvalho, para quem a computação foi a porta de entrada na animação, através da faculdade de construir e combinar imagens, seja em cinema, vídeo ou fontes diversas para produzir algo novo.

O trabalho do animador, propriamente dito, só teve a ganhar com a computação, de acordo os entrevistados da época da animação tradicional. Mesmo Joaquim Três Rios reconheceu - ao comentar a abertura da novela Tieta, feita por Hans Donner - o triunfo da computação sobre o trabalho manual de trucagem, uma competição desigual.

A combinação de técnicas completamente distintas, foi levantada como uma das faculdades mais interessantes da plataforma digital. Segundo Guto Carvalho, "o workflow, o modelo de produção de animação, não tinha a ver com o modelo de produção de live-action e quando o computador surge como plataforma unificadora, onde esses dois universos totalmente distantes tecnicamente passaram a conviver, criaram entre si uma nova relação muito forte. Isso sem contar a evolução da própria computação gráfica, seja como animação, seja como reprodução da realidade, a simulação, também, teve um papel muito importante na revolução audiovisual em que estamos vivendo.

O nascimento de novos profissionais, com novas habilidades e o ganho de flexibilidade no fluxo de trabalho foram relacionados por Daniel Messias como consequências adjacentes e não menos importantes da revolução digital. Para ele, o preço que se pagou pela 
qualidade na produção, na limpeza, na velocidade, foi acabar com o individualismo, com a marca pessoal nos trabalhos. "Não havia mais lugar para isso, assim como não há lugar para saudosismo", diz Messias. Os trabalhos ficaram de certa maneira mais formatados, veem-se mais estilos gráficos, mas não se reconhecem os artistas responsáveis pelos filmes, como outrora. Isso se atribui à exigência do mercado por volume de produção, não apenas para publicidade, mas para as TV's a cabo também. Quando surgiu, o computador catalisou mudanças, as quais retroalimentaram o desenvolvimento próprio dos softwares, que se tornaram cada vez mais "amigáveis" e próximos da prática artística do desenho, da modelagem e da animação.

\section{Aspecto dos filmes}

A fisionomia dos filmes acompanhou as mudanças técnicas, sem dúvida. A natureza própria da imagem do cinema, com a sujeira aleatória dos grãos, com a flicagem, o erro no traço que se transforma em linguagem, tudo isso, num primeiro momento, desintegrou-se, para dar lugar a uma certa assepsia, o que para muitos, era percebida como uma frieza e falta de humanidade. A percepção de que algo a mais deveria ser agregado à imagem de computador a fim de render-lhe uma característica mais warm, ou seja, mais orgânica e viva, como mencionou Baptista, veio acompanhada da rejeição, num segundo momento, de tudo que era criado no computador, como algo fácil, feito por técnicos e não por artistas. Entretanto, o desenvolvimento incessante e acelerado dos processadores e algoritmos tornou os dispositivos cada vez mais capazes de forjar a ilusão de relevo, textura, de organicidade, etc., que devolviam à imagem - não mais cinematográfica - um certo "conforto" visual, conferindo-lhe uma gama nova de atributos, inlusive flicagem e sujeira - controlados. A respeito do novo aspecto das imagens, um exemplo simples foi dado por Daniel Messias, para quem "mudou a cara realmente. Você tinha cenários que eram feitos em guache, ecoline, às vezes em acrílico, de repente passaram a ser feitos no Photoshop".

Na obra de Walbercy Ribas, o potencial das ferramentas digitais curiosamente não se reverteu em qualidades que colocassem sua produção digital em pé de igualdade com os prodigiosos filmes de sua fase Sharp ou Cotonettes. O filme Faber Castel II feito em 1992, uma atualização do Faber Castell de 1983, contou com elementos de computação gráfica e é virtuoso na animação 2D e na combinação com o 3D. Entretanto, um número bem maior de eventos sucessivos em cena, num ritmo acelerado de imagens, uma paleta de cores muito mais diversificada do que a do primeiro filme, além de uma trilha sonora evidentemente criada em 
sintetizadores, parecem tornar o filme uma peça mais preocupada com o virtuosismo permitido pelas ferramentas digitais do que com a sensibilização do espectador, que tem pouco tempo para apreciar a evolução das imagens na tela. Um estudo que relacione a natureza física das imagens em movimento aos fenômenos da percepção estética forneceria hipóteses para explicar o encantamento que o primeiro filme provoca e o segundo não.

A evidência dos aspectos positivos foi marcante nos discursos de Ribas e de Messias. Contudo ambos concordam que também houve perdas, por exemplo, a extinção de um modelo de trabalho em grupo no qual a reunião de profissionais resultava em colaboração e aprendizado para toda a equipe. Messias reflete acerca disso:

\begin{abstract}
O que eu mais sinto falta, da natureza do sistema de produção, é justamente essa congregação de profissionais. Porque, com isso, todos aprendem. [...] quando você junta uma plêiade de grandes profissionais, que tenham sensibilidade, que tenham, digamos, apuro, que tenham alguma cultura artística, você aprende com eles, é uma troca geral. Isso, você só consegue num sistema de produção de grupo de animação em estúdio. E hoje, a tendência é justamente isolar cada profissional, frente a um monitor, um tablet, às vezes trabalhando em home office. por uma série de razões. Uma delas é o conforto: é muito melhor você trabalhar em casa do que se deslocar até a firma diariamente. Outra, o trabalho em casa possibilita ao jovem trabalhar com $n$ fornecedores, ao invés de vender o serviço para um exclusivo, enfim, a tendência é cada vez isolar mais isso. E isso é ruim porque cria individualidades, cria gênios no computador, mas também cria pessoas que têm uma visão bitolada, uma visão estreita; a experiência que eu tenho conhecido aqui na produtora são pessoas muito mais voltadas ao trabalho exclusivo do computador. (informação verbal) ${ }^{153}$
\end{abstract}

Apesar dessa reflexão, foi consenso que a criação em animação não vai ser aniquilada jamais. As ferramentas vão mudando cada vez mais. Ao animar na prancheta ou num tablet Cintiq, o profissional atrás disso não é um técnico em informática, é um artista. Assim, quando Walbercy Ribas vaticina: "Sem talento, você não fazia animação; sem talento você faz computação", ele está sintetizando seguinte pensamento de Alberto Lucena Júnior:

O simples fato de aprofundar-se no domínio do programa já lhe oferece possibilidades concretas de criação visual. Sendo o trabalho em programa 3D, a inabilidade em desenhar e esculpir não seria um fator tão limitante. Nesse ambiente, o artista usa ferramentas que de certa forma fazem o trabalho por ele. No entanto, a tendência da evolução da tecnologia é permitir uma simulação completa da "metáfora escultórica", e aí um artista com habilidade tradicional de escultor leva grande vantagem." (JUNIOR, 2005, p. 440)

A experiência de sucesso de Alceu Baptista, exímio desenhista, escultor, além de

${ }^{153}$ Entrevista concedida por MESSIAS, Daniel. Entrevista III. [jan. 2013] São Paulo. Entrevistador: Maria Luiza Dias de Almeida Marques. 2013. A entrevista na íntegra encontra-se transcrita no Apêndice C desta monografia. 
profundo conhecedor de informática e programação, é, talvez, um dos exemplos mais precisos do que seria um sujeito operando a máquina criativamente, dando sentido à forma e ao movimento. Curiosamente, seu mais recente trabalho autoral tem sido pintura a óleo sobre tela, expressando talvez uma vontade de alimentar seu processo criativo, buscando nesta velha arte a essência que não pode se perder.

Chego ao final dessas considerações envolta em certa nostalgia da época estudada, do percurso trilhado no decorrer dos últimos meses, dos insights diários, enfim, de um mergulho vertical em questões caras para mim e que precisaram ser incansavelmente postas em cheque. Tenho consciência absoluta de que ainda há muito o que se explorar neste terreno e que sempre haveremos de encontrar visões concorrentes ou opostas, resultando algo que se sabe provisório, não obstante otimista, como proclama Arnaldo Gavão: "o futuro da animação é hoje!" 


\section{Roteiro das entrevistas}

O questionário a seguir foi estruturado pensando-se em abranger todas as questões ligadas à produção de um filme de animção em uma produtora comercial. Entendendo que cada filme tem particularidades e pode exigir $\mathrm{o}$ desenvolvimento de algum dispostivo/ferramenta específico, estas questões pretendem dar conta da produção de maneira generalizada em cada uma das produtoras em questão.

Formação/Influências

1- Qual a sua formação?

2- O que te levou a trabalhar com animação?

3- Quem te inspirou artisticamente?

O início

4- Quando abriu o seu estúdio?

5- Com que equipamentos contava?

6- Quem era a equipe?

7- Qual foi o seu primeiro filme?

8- Quem eram seus clientes?

Orçamento - considerando as diferentes épocas da existência do estúdio

9- Quem faz/ fazia o cálculo do orçamento dos filmes?

10- Como era a distribuição da verba? Quanto era destinada ao pessoal e à equipe? Quanto era destinado ao material? (papel, acetato, película, câmera e som)

Equipe

11- Quem definia o lay-out artístico dos filmes? (tipo de traço, paleta de cores)

12- Quem fazia a decupagem/ story-board?

12a- Havia animatic? Quem o fazia?

13- Quem era o responsável pelo sincronismo com o som?

14- Em média, quantas pessoas tinha a equipe de cada filme?

15- Quantos animadores trabalhavam fixo na casa? Quantos eram freelancers?

16- Quantos intervaladores? Quantos clean-ups?

17- Na passagem do desenho no papel para o acetato, fazia-se fotocópia ou filetagem?

18- Quem era o responsável pela finalização das imagens? Quam mixava com o som?

19- Em que mídia o filme era entregue?

$\underline{\text { Sobre os Computadores }}$

20- Quando ouviu falar pela primeira vez que o computador poderia ajudar na produção das animações? Pensou que isto ajudaria ou criaria mais problemas? 
21- Quando a sua produtora adquriu um computador? Lembra quanto custou? Qual era o modelo (especificações técnicas)? Quais funções desempenhava? Quais os softwares? Lembra-se do preço dos softwares?

22- Quem da equipe foi designado para aprender a lidar com a máquina?

23- Houve algum desconforto por parte de alguém da produtora?

24- Como o computador se integrou à equipe e à rotina do estúdio?

17 a - quais as tarefas do computador numa primeira etapa?

25- Conte o sistema analógico foi sendo substituído pelo digital na sua produtora?

26- A mudança do analógico para o digital foi uma necessidade interna (reduzir custos, por exemplo), ou externa (pedidos dos clientes e observação do que se passava no mercado externo)

27- Quando se percebeu que a configuração do estúdio teria que mudar?

28- Como esta mudança se refletiu nos orçamentos? E no tempo de execução dos filmes?

29 - Como a direção de arte se adequou às novas possibilidades?

39- Qual a sua opinião pessoal a respeito da característica que os filmes assumiram com este novo método de trabalho? 


\section{APÊNDICE A - Transcrição Entrevista TRÊS RIOS}

Entrevistado: Joaquim Três Rios (J)

Participação (gravação): Gilberto Caserta (GC)

Entrevistador: Maria Luiza Dias de Almeida Marques (ML)

Local: São Paulo- SP

Data: 27 de agosto de 2012

Duração da entrevista: 105 min

ML - Fale um pouco do início da sua carreira.

J - Eu trabalhava em loja de departamento como vendedor. Comecei a fazer desenho animado, a trabalhar profissionalmente em 1960. Meu primeiro teste de animação foi em 1959. Quando me deram o "Já é hora de dormir" prá fazer, eu fui na Lynx, o César Mendes me disse : "olha aqui, a trilha é essa", eu fui lá, marquei a trilha, fui prá casa, fiz o filme no prazo que tinha, entreguei o filme, e o filme foi pro ar, e hoje em dia é um "ei lá eu, um $\mathrm{AHH}$, esse filme"... é só um filme, um trabalho, a gente faz um trabalho... por exemplo, Globo Cor Especial, foi a mesma coisa, o Boni me ligou e disse: "Joaquim, cria um filme prum programa infantil, nós vamos lançar um programa infantil colorido", já era 1972. "... eu tô te mandando a trilha". Peguei e criei, sabe? Fui fazendo lá, as imagens, fui ouvindo e fazendo as imagens. Pôs no ar, ficou no ar quase 20 anos...

Meu $1^{\circ}$ filme foi $2^{a}$ Feira da Mecânica Nacional - para a Leo Pastro Produções como Free-lancer - em 1960. Cobertores paraíba veio depois, na Lynx filmes, com o Cesar Mendes. Forneceram a trilha, ele decupou, levou prá casa e fiz o filme no prazo que tinha e o filme foi pro ar, e hoje em dia é, 1972 (a cor começou em fevereiro, isso devia ser maio, por aí)

ML - Qual o processo de criação?

J - mandava-se a trilha e se cria o filme livremente; Trapalhões a mesma coisa, o Boni falou: "contratamos os trapalhões", a gente tá numa quarta-feira o filme é pro outro domingo.

ML - Nesse caso não tem nem aprovação?

J - Não! Fazia o story-board, mandava pro Rio, o Boni dizia ok, voltava prá mim e a gente começava a produzir; às vezes atrasava mais ainda porque não tinha trilha, mas aí começava a animação prá ser encaixada, as coisas acontecem, mas às vezes acontecem tb os desastres. Um risco total, às vezes não ficava bom e tinha que fazer outr vez...

$\mathbf{J}$ - Eu acho que fui parar no cinema, fui trabalhar com cinema graças à Branca de Neve.Eu devia ter uns 4 anos de idade, entre 4 e 5 anos, eu me lembro das coisas assim, era 193... o filme é de 1937, isso era 39, eu nasci em 34, eu tinha 4 prá 5 anos. Me lembro bem que um dia meu pai chegou em casa e falou de um americano que fez um filme, me lembro bem, parece que estou vendo meu pai entrar em casa, um americano tinha feito um filme de longa-metragem, tudo em desenho animado, eu não sabia o que era desenho animado, não sabia nem o que era um filme, tinha visto alguns filminhos, eu tinha um tio que tinha uma maquininha, uma Pathé-Baby, ele filmava e a gente aparecia nesse filme, desde pequenininho, esses filmes se perderam, não sei onde estão, devem estar com o filho dele... meu pai falou "nós vamos no cinema", já estava passando no cinema de bairro; mas nós morávamos em Santana, fomos ao Cine Cólon, se não me engano, na Voluntários da Pátria, nos emperiquitamos, eu, meu irmão e minha irmã caçula na época, depois eu tive uma outra irmã. $E$ fomos ao cinema, minha mãe, né, e quando nós chegamos ao cinema, a rua era um tormento, tinha gente prá todo lado, uma fila desorganizada, um empurraempurra, meu pai dizia: "vou lá na porta do cinema ver o que está acontecendo. Meu pai foi lá no cinema ver como era a coisa lá, e ele voltou dizendo: "não, não vamos entrar, vamos 
prá casa". E não fomos ao cinema naquele dia, fomos num outro dia, dia seguinte e eu assisti Branca de Neve. Eu tenho medo da bruxa até hoje, fiquei apavorado com aquela bruxa, adorei o filme, adorei aquela cor, ficou marcado em mim.

E Meu pai era um excelente desenhista, muito melhor que eu, eu nunca fui um bom desenhista, eu era um rabiscador, um garatujeiro, quebrava um galho, em terra de cego dava certo, e o meu pai, que era um belo desenhista, chegou em casa com uns papéizinhos, e ele construiu um cavalinho feito de papel, tudo recortado, as patas, tinha tudo, tudo,ele colocava o cavalinho em cima da mesa, ele montava a posição do cavalinho assim, com a pata assim, e desenhava nesse papelzinho. E fez um monte de desenhos lá e esses desenhos, eu o meu irmão e minha irmã pegamos um lápis e começamos a rabiscar em cima deles. A gente deve ter tomado uns belos tapas dele e nunca mais eu vi ele falar em desenho animado. E essa influência ficou em mim, tanto é que o primeiro filme que eu fiz foi o (teste do) cavalinho. Que é uma experiência que todo mundo que quer fazer desenho animado diz assim: "ah, você pega o filme ao vivo, copia os fotogramas e sai o desenho animado. Foi o que eu fiz, peguei o cavalinho e rotoscopiei o cavalinho.

Criação , música, está tudo muito perdido, não sei quem criou globo natal, globo cor especial, cobertores parahiba, varig, eu não sei quem criava, tinha aquele Arquimedes Messina, Gilberto Martins; música, eu não sei quem fez, mas eu sei quem fez as animações, eu tenho story-boards famosos; esse "não existe nada mais antigo"eu tenho ele assinado pelo Boni, com a seguinte observação do Guga: "Boni, imagina isso aqui em cores", o Boni respondeu: "ok, toca".

\section{ML - Qual a sua formação? formação prática total?}

J - Eu se fiz por si póprio, Fiz até o segundo ano colegial, parei, aí eu fiz 2 anos de desenho arquitetônico no Liceu de Artes e Ofícios, eram 4 anos, eu fiz 2anos, aí eu conheci a minha mulher, casei, aí eu comecei a falhar nas aulas e parei, me arrependo amargamente até hoje, não fiz faculdade. Não tô dando aula, por exemplo a FAAP já me convidou prá dar aula lá, mas eu não posso ir porque não tenho diploma, O Milton Costa era quem dava aula lá, aí ele foi atropelado e morreu, então o Máximo me chamou, eu fui lá, o Milton também não tinha diploma, não tinha nada, mas o Máximo disse assim: 'cê tem diploma?' eu disse: 'não tenho', 'puxa, se fosse até o ano passado, você podia entrar, porque tinha o emérito saber'. Então, eu não pude dar aula. Então, minha formação é $2^{\circ}$ colegial, nunca estudei desenho, não sou um bom desenhista, deu prá quebrar o galho na época.

Conforme fui progredindo, fiz mais ou menos como o Disney: se o cara ali desenha muito melhor do que eu, por que que eu vou desenhar? Eu criava, ia lá, 'eu quero a coisa assim, assado' às vezes eu dava um boneco, o animador vinha e 'olha, Joaquim, e se a gente fizer e, vez deste, este', 'beleza, vamos fazer'.

Aí, as coisas foram acontecendo, porque hoje em dia vc tem um monte de gente aí, indo pros EUA, fazendo sucesso, naquele tempo, no tempo que eu comecei, existia o Mário Lantana, o Gui Lebrun, o Mário fazia Casas Zacarias, um gênio. O Gui Lebrun também, um excelente desenhista, tinha o Milton Costa - que, dos três era o mais fraco, mas era um belo desenhista - e tinha mais 2 ou 3, tinha um cara chamado Mário Lanini, eu não me lembro de mais, eram 4 ou 5 que... televisão branco e preto, estamos falando de 1957, 58, 59, 60, em 60 eu comecei a fazer meus freelancers; em 1960 fui trabalhar no Léo Pastro. Existia isso, não existia mais nada. Então, quando eu fiz esses filminhos aí, eu fiz tudo por intuição, eu não conhecia nada, eu, por intuição sabia como se fazia o desenho animado e ia procurar, fui no Guy, fui no Mário, fui procurar.

Ah, tinha mais o Kingo Yamazaki, que trabalhava junto com o Mário. Aí, eu ia procurar, né, ver se eu conseguia fazer desenho animado. E procura daqui, procura dali, me mandaram numa produtora chamada Leo Pastro Produções, na Barra funda; o Léo tinha uma câmera, um table-top, um stand de animação, ele mesmo construiu com cano de água de 2“, era uma máquina que ele inventou lá e ele filmava desenho animado ali, ele filmava os desenhos animados do Gui Lebrun; o Gui, nessa altura feito um acordo com o Jacques Deheizelin, da Jota Filmes, e o Gui foi desenhar pro Jacques, foi fazer os filmes com a Jota, 
e o Léo ficou sem animador. Aí ele viu o meu cavalinho, e o vodka Eristof, o meu rolo era todo aquele, o Léo viu o rolo e falou: 'vem trabalhar comigo'.

Eu me lembro que aconteceu o seguinte: eu era vendedor de crediário numa loja grande chamada Modas A Exposição Clipper, eu trabalhava na PRaça do Patriarca; aí eu fui promovido a sub-chefe, eu ia prá São Caetano. Nessa altura, eu tinha feito já 2 ou 3 filminhos com o Léo, inclusive a abertura do Papai sabe Tudo, que fez sucesso, entrava no horário do Fantástico hoje, na TV Tupi, todo mundo assistia, esse filme ficou famoso, em 1960 ainda. Eu era freelancer, criação desse filme era do Wilda, da Lintas.

No momento em que eu fui promovido, o Léo me convidou prá ir trabalhar com ele. Só que eu tinha pavor, eu tinha um emprego, eu tinha mulher, tinha um filho, 'e se isso não dá certo, como é que eu vou fazer?' o léo, todos os freelancerzinhos que ele tinha, ele me dava, eu varava a noite, eu levava marmita lá na Exposição, comia a martita, ia na alfaiataria, achava uma mesinha lá e ficava desenhando, até a hora de voltar.

Então o Léo queria que eu fosse trabalhar, isso dia 31 de dezembro de 1960, o Léo me liga e diz assim: "Joaquim, eu tô indo pro Rio, e eu quero te encontrar na Viação Cometa na Av. Ipiranga com a Rio Branco, às $10 \mathrm{hs}$ da noite", eu disse: "Léo, hoje é 31 de dezembro", eu estava trabalhando, naquele tempo você trabalhava até as 6 horas, prá vender as roupas, etc. "Não, vamo lá e tal". Aí eu fui lá encontrar o Léo na Viação Cometa, que ele queria falar comigo. Ele estava atrasado, eram 10:30, eu já estava quase indo embora, quando ele veio, desceu do táxi, veio na minha direção, enfiou a mão no bolso, tirou um story-board desse tamanho, que lamentavelmente eu deixei lá na Léo Pastro, devia ter garfado este storyboard, que era da Mccann Erickson, esse filme da Esso, chamava Esso Bossa Nova; aquela orquestra era (a) do Ary Barroso, o cantor, eu não sei, mas... A Esso era o maior anunciante do mundo naquele tempo.

Ele me deu o Story-board na mão e disse: "quero que você faça esse filme". Eu olhei, falei "Oh, que beleza!". "Só que eu quero que você faça isso lá na minha casa." O estúdio dele era no fundo do quintal, numa sala muito boa, tinha umas mesas velhas, lá, mas era boa luz, etc. Eu falei: "Léo, não dá, eu trabalho numa firma, preciso pedir demissão..." "Não, não! quero que você vá prá lá. Escuta, quanto que você ganha?" Não deu tempo de eu pensar. Ele disse: "Manda esses caras à $\mathrm{m}$... que eu pago o dobro prá você."

E entre as 10:30 e a meia noite, a hora em que ele saiu, eu, que ganhava $\operatorname{Cr} \$ 14,15$, $17.000,00$ na A Exposição, até a meia noite, eu já estava com 50 pau no bolso. Ele me dava Cr\$50.000 prá eu trabalhar prá ele, e mais comissão, e mais não sei que lá. Eu tinha compromisso, eu tinha sido promovido a subchefe, já tinha dito que faria, depois eu recusei. Ele tomou o ônibus e foi embora, "então eu vou chamar o Mário Lantana, que o Mário faz isso, ele resolve, vou contratar ele, você perdeu a sua oportunidade", eu não tinha conhecimento da ligação dele com o Mário; na hora que o ônibus ia saindo, ele abriu a janela e disse: "na segunda-feira a gente conversa!" fechou a janela e foi embora. Eu vim prá casa, falei com a Terezinha, isso, dia 31 . Eu só fui trabalhar no Léo no dia $1^{\circ}$ de março.

Minha mulher estava grávida naquela época, no 31 de dezembro, minha filha nasceu no dia 27 de fevereiro, eu mudei de casa, comprei uma casinha lá na Vila Granada, prá lá da Penha, mudei de casa, nasceu minha filha e aí eu fui pro Léo Pastro. Prá mim ir pro Léo, eu chamei o meu chefe, antes de mais nada, a gente foi tomar café, expus o caso prá ele, ele disse assim, "óh, faz o seguinte: vá embora, vá trabalhar com eles, se não der certo lá, você volta prá Exposição, vai prá Clipper, vai prá Ducal, prá Garbo, você é um profissional que vão aceitar em qualquer coisa, você é bom"...

Aceitei e fui pro Léo. Comecei a trabalhar dia $1^{\circ}$ de março. Foi quando eu fiz os primeiros filmes. Aí, um dos primeiros filmes foi "Varig pros Estados Unidos", criação do Boni - eu não sabia, eu não conhecia o Boni - com desenhos, as figuras eram do Laerte Agnelli. Eles trabalhavam em dupla. Fizemos 3 ou 4 filmes, e um dia o Léo me disse assim: "Vai procurar o Oliveira na Multi Propaganda", que ficava ali na Marechal Deodoro. Eu cheguei lá, entrei na sala e... eu quero falar com o Seu Oliveira. Fui lá e, o Boni sentado numa mesa e numa prancheta tava lá o Laerte. Aí, o Boni me deu na mão o story-board do Varig "Carta de Amor". "Quero que vocês façam esse filme aqui". O primeiro filme eu não tinha gostado muito, eu era principiante, tudo feito no chute, filha, 
ML - Que tipo de contrato você tinha? Ele pagava por filme ou um fixo mensal?

J - Eu tinha um contrato, mas não pagava imposto, nada disso, Ele me pagava: eu fui prá lá ganhando Cr\$50.000,00, mais comissão, $5 \%$ nos filmes que eu fizesse, mais $3 \%$ nos filmes que eu contratasse um freelancer e eu dirigisse o filme, e se entreasse um filme só prá eu dirigir a filmagem, mais $2 \%$, eu não me lembro, então, eu recebia +- assim uns $\mathrm{Cr} \$ 60.000,00$ por mês. Tinha mês que era menos, aí o meu salário foi aumentando, e eu trabalhava sozinho lá. Aí, um dia, nós contratamos uma filetista que tinha saído do Guy depois voltou pro Guy, nunca mais vi essa moça. Depois a equipe foi crescendo, contratou o Walbercy Ribas (em 1962), trabalhei pouquíssimo tempo com o Walbercy; outro cara, a gente chamava ele de Tom Bell, o Airton Gomes, fez um curta-metragem interessante naquela época. A equipe éramos eu o Walberci e o Airton, tinha umas 4,5 pessoas que a gente trabalhava lá, no fundo da casa lá.

ML - Já tinha mesa de luz?

J- Não! Ainda não tinha mesa de luz - trabalhava com prancheta com 2 pinos e papel vegetal. O Guy trabalhava assim, o Mário Lantana trabalhava com papel também, não sei se ele tinha back-light.

ML - Quando que entrou a mesa de luz?

Joaquim - Isso é bem mais tarde, minha primeira mesa de luz... a Lynx filmes trabalhava com mesa de luz, pessoal da Lynx, eu não conhecia ninguém né, Ruy Perroti, Daniel Messias, Eli Barbosa, essa gente eu não conhecia, eles trabalhavam na Lynx, inclusive, fui convidado, quando eu fiz o "Carta de Amor", o Boni me recomendou pro César, o César ligou prá mim, queria que eu fosse prá lá, eu falei, "não, eu tenho contrato com o Léo", por dois anos, eu vou ficar aqui os dois anos. A minha primeira mesa de luz, foi o seguinte: quando fizemos o Globo-Cor Especial, quando a coisa pegou no breu com o Boni, a gente filmava tudo na Truca, do Joseph Reindl- o cara mais importante do cinema, ele fazia trucagens, era um tcheco que tinha vindo pro Brasil naquela leva do pessoal que veio prá Vera Cruz. Ele construiu uma truca na casa dele, com duas câmaras.

ML - Imagem aérea?

J - Que imagem aérea? era uma câmera de frente prá outra, do tempo de televisão a lenha. Nessa ocasião, então, o tabletop do Reindel, a gente filmava lá na casa dele, lá no começo da Cupecê, era uma tábua com uma coluna e uma câmara, que eu não sei que marca que era, não era nem francesa, nem inglesa, nem americana. Ele batia o fotograma, a máquina não funcionava, ele pegava uma régua e batia assim "kéh" em algum lugar lá em baixo; em 1972, o Reindel importou uma Oxberry, não, Oxberry não, chamava Newson and Order, era uma câmera com 3 pinos, mas a gente filmava com 2 pinos; e entre 72 e 73, o Boni falou de Vila Sésamo, a parte nacional do Vila Sésamo, fomos nós quem fizemos. Uma hora e tanto de desenho animado que se perdeu, jogaram fora;

ML - e o Sítio do Picapau, vocês que fizeram?

J - Não. No Sítio do Picapau, o Hans Donner já estava aqui, na Globo, eu tô falando do começo dos anos 70. O Reindel importou oxyberry com aereo image, só que ninguém sabia o que era aquela p... ele fazia as trucas dele, a gente não sabia nada, O Boni falou em Vila Sésamo, então nós vimos que precisávamos se profissionalizar prá trabalhar melhor. E aí, alguém tinha um disco de animação. $O$ Reindel pediu o disco emprestado, o mecânico chamado Markian fez uma forma desse disco e desse disco, e desse disco, começaram a fabricar os discos nacionais. Olha eu comprei 4, o Daniel Messias comprou também 3 ou 4, 
o Reindel comprou 4, durante mais de 20 anos ele vendeu os discos de animação. E assim que nós nos profissionalizamos, construímos as nossas caixas de luz, começamos a trabalhar com 3 pinos; a furadeira, também o Reindel conseguiu emprestado de alguém e o Markian copiou; depois, só muito mais tarde eu importei discos de animação, até de campo 18, campos maiores. Depois, o meu estúdio veio prá aclimação. Fiquei aqui anos até fechar.

ML - Quando que fechou?

J- No dia 16/03/1990, o canalha do Collor tinha uma bala só na agulha, acertou na minha testa; não que ele me tirou dinheiro, ele não me tirou um tostão; eu tinha uma equipe grande, não era tão grande como antigamente, mas era uma equipe de 15, 20 pessoas; os clientes ligavam e diziam "Pára tudo"; equipe de produção da Sales, imagina. Refinações de milho Brasil, nós já tínhamos feito 5 filmes prá eles, a série ia continuar, tinha umas trucagens complicadas que a gente ia fazer em Miami; orçando o filme já pronto prá começar a produzir. O cara da Sales liga e diz assim: "Joaquim, pára tudo. Nós fomos todos mandados embora". O meu serviço imediato foi embora ali. A Globo não fazia mais nada, sei lá eu, as agências, ninguém fazia nada. o cara só trabalhava no mínimo possível, porque não tinha dinheiro; eu tinha uma equipe de 20 pessoas, das quais, entre as 5 eu gastava assim 20 milhões, 25milhões. Eu tinha um cara que ganhava 6 milhões, outro ganhava 5 milhões. Depois tinha o resto da equipe; a mulher da limpeza ganhava 900 mil... Uma inflação de $80 \%$, aí eu chamei o meu administrador e perguntei: "que que eu faço, Rubens?" ele falou: "me dá meia hora que eu vou checar como estão as coisas por aí. então, ele voltou na minha sala e disse: "se eu fosse o sr eu punha todo mundo na rua e tentava seguir sozinho, porque nós vamos ter dinheiro prá pagar esse mês, mes que vem, depois não tem mais. Chamei todo mundo, negociei aviso prévio. Uns foram pro Japão, uma das minhas funcionárias foi prá Portugal, outros foram se virar por aí e eu fiquei sozinho. Ficamos eu e uma secretária durante 3 anos - ela fazia café, regava as plantas, varria a casa... eu fiquei sozinho por mais 6, 7 meses. Aí a dona da casa que eu tinha contrato, a mulher me chamou prá aumentar o aluguel, triplicou o aluguel, e me pôs um advogado em cima, aí eu pedi 6 meses, e eu negociei por mais 6 meses, doei tudo o que tinha lá, algumas coisas foram para o Senac.

Eu estive no estúdio do Disney, em 1974, e fiquei convesando com um animador chamado Cliff Nordberg, era um velhinho lá, e eu achei... era uma tábua, uma prancheta de desenho, com um furo, ali encaixa o disco de animação, a lâmpada fica presa num coiso ali.

$M L$ - Como eram feitos os brieffings?

ML - Brieffing: a agência chama, primeiro tem reunião de orçamento, então, chamam meia dúzia de produtoras, vai todo mundo lá, explica o que é o filme e todas fazem um orçamento, volta lá, vai falar com os criadores, etc, ou senão, eu fazia mais vinheta do que qualquer outra coisa, a Globo me chamava, eu ia lá, dava um logotipo do programa e pedia uma abertura. Vale a pena ver de novo, eu quero uma abertura, eu vinha prá São Paulo fazia o filme. Às vezes nem fazia story-board, fazia o filme direto. Era prá ontem. Eu nunca tive um filme que o Boni dissesse "olha, isso aí tá uma porcaria, nós não vamos usar", nunca, nunca. Ele confiava na gente. O máximo que acontecia era corrigir aqui e ali, isso aqui não tá bom, tira isso aqui fora, ficou muito comprido, tinha tb o problema de encaixar no tempo certinho.

ML - o tema dessa pesquisa é entender como a entrada dos computadores mexeu com a imagem...

J - Até hoje, desenho animado é desenho animado, seja na mão seja no computador, vc sabe que se vc não desenhar ele não acontece. Naquele tempo a gente fazia o desenho animado mesmo, usávamos o aerógrafo, até que nós descobrimos o raio do back light, chegou o aero image aqui e fomos descobrir o back light. E aí começamos a fazer coisas, misturar, começamos a fazer coisas mais complicadas, nós tínhamos a máquina de fotolito, 
tá lá na cinemateca, todas as minhas coisas estão na cinemateca, table-top, etc. A gente fazia pilhas e pilhas de fotolito. Não tem aquele filme da coca-cola? o logo-tipo vira assim, né? isso aí foi feito do jeito você não imagina: nós tínhamos uma xerox standard, parece máquina de lambe-lambe, uma máquina de fole, vc punha a placa aqui, prá fazer a cópia do desenho, a gente copiava o desenho no acetato, em vez de filetar, que antes era filetado; depois as xerox automáticas conseguiram uma adaptação prá celulóide. Então, eu tinha 2 xerox standard (que estão na cinemateca tb), a gente desmanchava o sistema de luz da xerox, colocava o photo flood da xerox por trás do vidro, fazia umas traquitanas, por exemplo, um cabo de vassoura com um disco, um disco que girava e o cabo de vassoura virava assim. Foi assim que foi feito o filme da Coca Cola. (Ele desenha um modelo desta traquitana.)

Cada fotolito, cada um deles, perfurava, retocava. Fazia teste de filtro até achar o vermelho da cocacola; um filme de 5 seg. A gente gastava $200 \mathrm{~m}$ de material com teste de cor, até chegar naquela cor. Isso, já depois do fotolito. Os fotolitos da Coca Cola (1982 ou 1985). É o 3 D na mão. Nunca fiz nada com computador, mas fazia tudo "com puta dor". Tudo sofrido. Tinha que inventar, resolver e fazer. O sujeito vinha e dizia "eu quero um filme assim".

Por exemplo: o Boni me chamou uma vez o Boni não, o Hans me chamou e disse a Rede Brasil Sul vai mudar de logotipo. O logotipo é esse, desenhado, e vai passar prá esse tipo tri-dimensional. Eu preciso do filme. Vim prá SP, mandei fazer o mocap do logotipo, montamos numa traquitana mais ou menos parecida com isso aí que eu desenhei (eu sou do tempo do Domingos Timura) esse é mais maluco que eu; me deram o mocup eu fui num fotógrafo, e numa traquitana parecida com esta daí, e vai virando o logotipo do jeito que eles queriam. E cada uma dessas aí, cada fotografia, você tem relevo, sombra, etc, então, o mockup já era pintado como logotipo, fotografia a cores. Primeiro a gente fotografou com 18X 24 pilhas de $20,30,40,50$, cromos. Tinha que revelar tudo junto prá não mudar o banho, por que se não mudava de cor. As oxberry tinham fusão automática. Você colocava lá 24, colocava 190, fazia 190. O meu tabletop era uma Mitchel, ela era $n^{\circ} 198$, era da Vera Cruz. Ela era blimpada na época. Eu desmanchei o blimp, a câmera tá descascada, e era esta a câmera que estava no meu table top. Nesse câmera vc tinha que fazer na mão. $O$ filme das estrelinhas - o Fantástico: aquilo primeiro fizemos o letreiro "Fantástico", pusemos no table top e filmamos o zoom com pantógrafo, então o letreiro entrava daqui pequenininho, com a câmera lá me cima, grande-angular, pegava fora da câmara assim, tinha que colocar cartão preto em tudo quanto é lugar, então, aquilo com o pantógrafo vinha vindo assim, fazendo o movimento (curvilíneo), começava lá em cima, com letrerinho ali, isso tudo filmado em alto contraste. Pegava esse alto contraste jogava isso no aereo image, com filtro de cor, e aí então o letreiro vinha vindo até primeiro plano, a cabeça branca; aí voltava o filme, o rastro é cor. O rastro, vc pulava sei lá 10,20 posições de fade, e começava, em vez de começar na posição 1 de fade, já começava na 20, na 21. Aí, da 21 em diante, ia fazendo fade, fotograma por fotograma, até desfazer aquele rastro. $E$ isso, graças a Deus este filme foi feito lá, lá você tinha o automático. Era um fade de $120 \mathrm{ftg}$, começando no fotograma 20: a cabeça, primeiro filmava a cabeça, no aero image. Aí, voltava no primeiro ftg; colorido: agora é o vermelho então, cada um deles, a câmara disparava e ela ia no fade, até o fim, fazendo o fade. E era assim, e passava dias, e dias filmando.

ML - este trabalho bem mecânico envolve um monte de contas, não é? Você ficava ali em cima também fazendo, ou tinha alguma pessoa?

J - ah, sim, uma ficha de animação perfeita. Nós chegamos a fazer coisa aqui no quadro-a quadro. Eu acompanhava tudo; houve momentos que eu tinha uma funcionária que eu confiava nela plenamente. No comecinho tinha o Takeshi Sakaguti, hoje em dia ele tem a produtora dele, eu confiava no trabalho dele plenamente. Mas eu acompanhava paripassu.

Eu me lembro que um dia disseram prá gente: "a globo quer fazer um filme..." eu não tinha nem idéia do que seja, "... a abertura de uma novela que a globo ia fazer chamada Tieta do Agreste". Era o seguinte: uma imagem que vai girando, uma moça que gira e se vai se 
transformando numa árvore, numa... qualquer coisa assim. E depois disso outra imagem, outra posição prá outra coisa... "E Eles vão fazer no computador e eu não tinha idéia do que seja. Quem fez foi o Hans, a abertura é espetacular...

GC - Mas é chupado do Zbginew Ribcinzki...

J - Ah, mas eu não sabia desse cara, aí eu chamei a Agnes e falei, vamos fazer um negócio aqui, nessa época já tinha também outro sujeito, que também era um gênio, chama Jorge Fujiharauma, o Jorginho, chamei o Jorge e a Agnes e falei: "tem uma abertura que é assim, uma coisa que se transforma em outra. Então, eu peguei umas estatuetas de barro, pusemos numa prancha. A gente foi virando e fotografando (em $35 \mathrm{~mm}$ ) 360 . Pegamos a outra imagem, e fotografamos também em $360^{\circ}$. Aí, tínhamos os fotolitos de cada uma dessas - em branco-e preto, era teste - Aí, eu mandei fazer uma trama de faixas, máscara e contra-máscara. Eram 2 fotolitos só. Um, que era uma série assim, e o outro era o negativo dele. Então, pegamos, por exemplo, a primeira imagem, aí, pegava linha por linha, só fotografava aquele pedacinho dela, dela girando. E aí, pegava a outra imagem, daquele momento em diante e começava a outra imagem girando, aí, passava prá linha de baixo, fazia a mesma coisa, só que começando um fotograma depois. Então, o que que acontece? então, lá em cima, gira prmeiro, depois mais embaixo, gira, gira, gira, você fica com a figura assim toda retorcida. Isso foi feito no computador lá.

ML - chegaram a mostrar prá eles?

J - Não! o filme já estava sendo feito. Eu vi no jornal que eles iam fazer uma abertura assim. O jornal explicava: "uma figura se distorce e transforma em outra." Fizemos, vi no jornal o que eles estavam fazendo. Eu tenho isso em $35 \mathrm{~mm}$. Precisava telecinar. Então, é isso, as coisas eram feitas desse jeito.

GC - Nessa época eu também tinha empresa, e nós fizemos também lá, a gente botou um cara prá programar, e fazia isso: cada linha de um frame e a linha de baixo, do frame subsequente.

ML - o pensamento lógico é o mesmo.

J - Nessa altura, primeiro a Globo comprou um computador nos EUA, em São Francisco.

GC - A globo fez parceria com a PDI, que é Pacific Data Images, lá nos EUA. O Zé Dias era o cara que fazia a ponte técnica com essa empresa, a Globo colocou dinheiro na PDI, então, começaram a produzir lá antes de ter esta técnica aqui no Brasil; durante alguns anos eles finalizamvam lá; depois o Zé Dias montou um núcleo de computação aqui.

J - O nosso trabalho de back lilght, a gente se baseava nos primeiros trabalhos do Bob Able - "o cara que inventou essas luzes que andam" - exposição prolongada.

GC - Foi um dos primeiros a mergulhar na computação gráfica. Tem uns clássicos, uns filmes da Benson's e Hedges de cigarros, seven up, são de arrepiar, é muito legal. Os filmes dele sempre estouravam prazo, ele fuçava, pesquisava.

J - Robert Able and Associated, se chamava a firma dele. Ele tinha um aero image com tela de 40" um condensador. Tinha um dolly com 10, 20 metros. Aí ele foi evoluindo pro computador. Começaram a fazer coisas automatizadas, participou do ET, eles têm outra tecnologia muito na frente da gente; a gente, nessa ocasião, se baseava no Bob Abel; antes disso, o meu inspirador era o Saul Bass; Eu estive no estúdio dele, fiquei com ele duas horas; (1:21:43) esse cara apareceu em 1952; eu vi Carmen Jones, Volta ao Mundo, esse cara era sensacional. Um dos maiores designers. 
Um dia começaram a falar que ia começar a imagem computadorizada. Aí, apareceram uns livros, fui ver livros, isso foi em 1970, mais ou menos. E tinham aquelas imagens era um monte de desenhinho, um em cima do outro, fazendo aquelas figuras assim.. e eu falei: "agente precisa ver o que é computador." Era tudo em branco e preto, mas esses desenhos que apareciam nos livros eram coloridos.

ML - Não te assustava pensar em ter que trocar todo um sistema por outro?

J - Não, não, eu não imaginava; eu sempre disse que o cinema só acabaria quando a televisão tivesse $80 \%$ da qualidade dele. Hoje a televião já passou o cinema. Mas, isso foi mais ou menos em 70, começaram a aparecer coisas aí. Eu comecei a fazer testes. Todos esses filmes que a gente fez aí inspirados no Bob Able, tudo isso era feito "com-puta-dor", como eu disse né, imitando o grafismo do computador, que eram os primeiros faquela época e eu não sei como eles usavam. Eu nunca soube como eles usavam acho que não vou saber nunca.

Um dia eu fui pros EUA (novembro de 1974) visitar os estúdios em NY, SF e LA, 40 dias; foi onde eu conheci os estúdios Hanna Barbera, fiquei amigo do Robert West, morreu já, nos correspondemos durante anos; e íamos ver estúdios de computação gráfica. Acho que uns 15 dias antes da viagem a McCann chamou todo mundo prá ver o trabalho de um americano qualquer lá, que tinha o trabalho de computação gráfica. Eram uns logotipos que faziam assim (gesticula, sem jeito). Eu pensei, : "Isso a gente dá um jeito de fazer aqui", era tudo coisa que era ruim, uma qualidade ruim, cheia de pipca. "Isso aí não vai dar certo". Tanto é, que nós fomos pros EUA, fomos visitar uma porção de estúdios e eu não fui ver o computador. Não acreditei "Isso Não Vai Dar Certo".

Em 1952, eu escrevia sobre rádio e eu sugeri ao meu chefe, o grande publicitário chamado Jobel Pontes Lopez, escrevermos sobre TV, a televisão tinha 2 anos. Ele disse assim: "ah, bobagem falar de televisão. Isso aí é uma coqueluche, não dura, a hora que passar o impacto, isso acaba. A televisão não vai prá frente." Ele não acreditava na televisão. E eu fiz a mesma coisa com o computador;

Então, eu tinha ido prá lá prá ver como é que era, chguei ir a alguns lugares, mas eu não vi detalhe de coisa nenhuma. Tinha umas salas super geladas com uns armários encostados na parede com uns discos deste tamanho, com umas fitas enormes, aquilo corria prá frente prá trás, aquilo era o computador. Umas máquinas enormes. Prá começar, eu não tinha dinheiro nem prá comprar um carretel daqueles, quanto mais uma máquina destas.

Continuei fazendo filmes. Em 1970 a gente já sabia, o Bob Abel já estava usando o computador, já estava estudando as coisas prá passar do cinema pro computador. Mas, o computador, pro Bob Able, na verdade, usava o computador de outro jeito: ele tinha esse aereo image que ele bolou aquelas loucuras, e o aero image usava a matemática do computador. Como as máquinas que o Reindel comprou em 1972, as Newson and Order, que o computador fazia... só que a gente não sabia usar aquilo. Só usava o zoom e a fusão.

GC - O que se fazia no Fantástico, eles faziam por computador, multi exposições com o mesmo movimento de câmera.

J - Isso, ele marcava no computador: a câmera vai fazer este movimento, fazia o movimento pro vermelho, pro azul, etc, e dava tudo certo. Nós não, tinha que fazer um fotolito prá cada um e filmar cada um. e fazer fusão prá cada um, fazer o zoom prá cada um, aquelas estrelas que vc disse que viu no filme, que aliás, são as mesmas, tá no Fantástico, tá no Monroe, e mais em outras coisas. Quando eu precisava fazer um céu estrelado pro Fantástico, eu já sabia como é que eu ia fazer, Então, nós compramos um cartão Fabriano preto, e tudo pintinha nele, tinha 8 ou 10 cartões desse aí. Aí, pusemos cada um desses lá na câmara, iluminamos, filme alto-contraste na câmara, aí faz um zoom aqui de $1000 \mathrm{ftg}$. Você regulava na máquina $1000 \mathrm{ftg}$, a câmara vinha sozinha "tec-tec-tec-tec". Tirava este cartão, ou punha ele de ponta-cabeça, voltava o filme prá trás, fazia a mesma coisa, o 
mesmo zoom, agora em $600 \mathrm{ftg}$. Não era tanto fotograma, eu acho que o máximo que nós fizemos era $400 \mathrm{ftg}$. Depois a gente fazia fusão de um pro outro. E continuava, voltava o céu pro começo, cada zoom numa velocidade, então, cada estrela anda numa velocidade diferente, né. $\mathrm{E}$ fizemos uma ou duas andando levemente ao contrário, prá dar mais profundidade ainda. Elas não se afastam, parece que elas estão só se perdendo.

ML - Essas idéias vocês tinham antes de filmar, de como fazer?

$\mathbf{J}$ - As idéias partiam de mim; às vezes tinha a idéia na hora. De vez em quando vc tem idéia que o cliente aceita, mas essa idéia (da Tieta), eu tentei vender essa idéia, eu não tinha visto, eu sabia que a Globo tinha feito, a novela ia entrar, isso foi num prazo de um mês antes da novela entrar, porque você sabe das coisas, corre, um cara conta prá um, conta prá outro, e você fica sabendo. Eu sabia dessa vez, fizemos este teste, Fizemos até prá um produto, Lojas Marisa, não sei bem, fizemos uma sugestão, eu tenho o story-board guardado, feito com as listinhas, as nossas listinhas eram de $3 \mathrm{~mm}$, também não sou louco de fazer um monte de... aqueles do computador eram uma linha de televisão por vez, né? Eles não aceitaram. Não, isso é bobagem. Aí o filme deles foi pro ar e nunca mais se falou nisso. Eu não consegui vender a idéia prá ninguém. De vez em quando você tem umas idéias que o cliente aceita.

O collor acabou comigo, eu tive que demitir todo mundo. Fiquei sozinho, isso em 1990, fiquei sozinho durante 3 anos. Agente fazia uma média de 2, 3 filmes por mês por baixo; em alta, fazia 5, 6 filmes. Em 3 anos eu fiz 2 filmes. Por que quando vc pára um pouco, corre o boato: "o Joaquim não vai bem das pernas, vão te pondo no escanteio". Eu acabei assim, talvez eu tenha errado; se eu não fizesse isso, eu acho que eu tinha morrido, eu não tinha condição nenhuma de manter status. tentamos... você sabe o que é fazer 2 filmes em 3 anos? Aliás, era o mesmo filme, que eu fiz prá CEASA, era um concurso aí, prum amigo de longa data que me chamou, "Joaquim, vamos fazer isso aqui", e me deu esses 2 filminhos a troco de banana, e eu fiz. Contratei um animador, eu não tinha condição de acompanhar, nessa época, 1990, os animadores que nós temos são de nível internacional, tinha que contratar. Aí, contratei free lancer prá fazer arte-final, eu mesmo xeroquei todas as artes, eu mesmo que limpei as artes, eu mesmo filmei sozinho, eu e o animador, isso foi feito já no meu estúdio, aqui na Av. Aclimação.

Sobre a trilha: trilha sonora; um monte de comerciais aí, o comercial do cavalinho, Bolo Califórnia, eu não sei (de) quem é, meu filho trabalhava comigo, ele era contato, ele já tem 54 anos, é capaz dele dizer, "pai, não me lembro". Eu tenho uma ficha de cada filme, não são muito completas, faltam coisas.

\section{ML - Quando a Globo comprou o equipamento de computação deles, eles não convidaram?}

J - não, não fiquei sabendo nada. Eu tive muito contato com o Boni, Nelson Gomes, meu amigo até hoje, com o Hans Donner, mas muito, muito contato, com o Milton Nunes, que é o cara que faz as letras da Globo, e com uma porção de outras pessoas, mas não era uma relação de amizade. São meus clientes. o Boni me chamava lá e dizia "Joaquim eu preciso disso aqui prá tal dia", acabou o assunto. O contato mais próximo que eu tive com o Boni foi quando ele ligou e disse "O Henfil vai te telefonar", nós vamos eu quero por uma série do Henfil, nós temos uns desenhos aqui do Mordijo, que nós estamos pondo no ar, mas nem todos eles servem para o propósito da gente e eu vou tirar do ar, e eu quero por uma séire do Henfil. Aí fomos lá no Rio conversar com ele, etc, e durante 2 meses ficamos trabalhando nesse projeto, que resultou nesses 2 filminhos, que o Boni aprovou assim: " ôh, beleza eu quero isso no ar!" Era véspera de carnaval, "eu quero isso na semana que vem". Já tinha 100 roteiros prontos, tudo eu e o Henfil. E, o Boni aprovou, mas o pessoal da casa não aprovou, ele ligou e disse: "Joaquim, vai ficar muito caro, a Globo não está interessada em gastar esse dinheiro, então nós não vamos fazer". E acabou o assunto. Nunca mais se falou, Nunca mais vi o Henfil, falei com ele quando ele estava doente, mandei 2 ou 3 telegramas prá ele, já no finzinho da vida, prá dar uma força, depois nunca mais falei com o Henfil; o 
Henfil foi em 1983, 84, não me lembro. Foi o contato mais longo, porque o Boni ligava e dizia: "preciso de você", e eu pegava um avião e ia prá lá, ele ligava de manhã, na hora do almoço eu estava lá. "Que que você quer? Prá quando você quer? Precisa Story-Board?" às vezes ele dizia: "Faz direto, sem story-board". Às vezes ele mandava o story-board.

\section{ML - E no Rio de Janeiro não tinha quem fizesse?}

J - Tinha, tinha um monte de concorrente, mas ele mandava fazer, graças a Deus; ele confiava, e quando o Hans chegou lá, ele viu o trabalho do Hans era bom, e o Hans tá lá atá hoje. Isso é assim, ele gostava do meu trabalho e a gente fazia. Se ele mandou outros fazerem, eu não sei. Eu fiz Globo de 1969 até 1986, no fim, cada vez menos. Quando o Hans chegou aqui, já começou a diminuir. Só que, mesmo com o Hans aqui, eles me chamavam lá no Rio e diziam: "Joaquim, olha," sabe aquelas vinhetas que eram mais casca de ferida, davam prá mim; lá tinha um quadro com um monte de vinhetas prá fazer, tudo em aberto, não estava nada pronto. Eles me davam uma, eu vinha prá São Paulo, fazia, voltava lá, eles riscavam a minha, as outras continuavam em aberto, eu vinha prá São Paulo fazia outra, cgava lá, tinha mais uma riscada, fazia 4 ou ; muitas não eram feitas, outras eram feitas por eles, mas eu não tinha noção nenhuma do quem estava fazendo, nem tinha como perguntar. Era um relacionamento totalmente profissional. Aliás, sempre tive medo de ser amigo de um cliente. Eu achava que cliente era ele lá e eu aqui, fazer o melhor possível e acabou o assunto. Até agora eu sou assim. Só que agora eu não faço mais nada. Quando eu estava no finzinho, eu ia entregar o estúdio, eu rasguei toneladas de papel e de acetato, joguei tudo no lixo. Nessa ocasião, faltava um mês prá entregar a casa, toca a campainha, tá lá essa figura (Gil Caserta). Chegou aqui e disse: "Olha, eu tenho um projeto no SENAC, semana que vem vão inaugurar uma sala de computadores, e eu queria que você fosse prá lá prá gente fazer animação. Fomos lá no SENAC e me contrataram prá fazer dois cursos. Levei todo o meu equipamento pro SENAC, moviola, etc, ficou tudo lá, eles não levaram nada prá frente. Fomos prá lá, fizemos o primeiro curso, em 1993.

GC - Lá tinha ilhas de PCs, de Mac e de Amiga. O Amiga, mais voltado para vídeo, os MAC, mais prá editoração, e os PCs, 'tava começando a surgir as placas gráficas, que você começava a usar 3D, essas coisas. Então, (no curso) os caras viam o tradicional, e iam prá tecnologia... A história do Cinema, até que a gente tem muita coisa documentada, mas na televisão, não sei se, pela velocidade, ou por menosprezarem a televisão, em certo aspecto, acaba passando batido, né, então, eu brinco com o Joaquim, a evolução da comunicação visual na TV está no rolo dele. Começa naquelas coisinhas de Esso- Bosa Nova e vem até multi exposição... chegou na borda do computador.

\section{ML - Quem fazia o cálculo do custo de um filme?}

J - Na minha produtora sempre fui eu o responsável pelos orçamentos. A princípio por tentativa e erro. Depois peguei o jeito e orçava, conforme a complexidade do trabalho.

ML -Como era a distribuição do dinheiro? Quanto da verba era destinada para o pessoal, quanto era para o material? (papel, acetato, película, câmera e som)

J - Para os trabalhos digamos, mais normais, havia uma regrazinha, se não me engano inventada pelo Guy Lebrun, que geralmente dava certo: $1 / 3$ era para o trabalho de criação e animação; $1 / 3$ para a arte final - incluindo material e filmagem - e 1/3 para a produtora incluindo impostos, etc. Quando a coisa era mais complicada o jeito era fazer contas pra que não desse problemas no final.

Por exemplo uma "refação" (a palavra não existe no dicionário, mas era assim que a gente chamava o ato de ter que refazer um filme) custava uma "fortuna" e a gente procurava se precaver. 
ML - quem definia o lay-out artístico do filme?

J - Como nosso trabalho quase sempre era encomendado, todas as definições eram feitas entre o cliente (geralmente a agência) e a produtora.

ML - Quem fazia a decupagem/ story-board?

$\mathbf{J}$ - Muitas vezes os story-board vinham da agencia, mas quem sempre definia a decupagem final do filme era eu.

ML - Havia animatic? como era?

J - Que eu saiba não se fazia animatics para animações (eu não me lembro de ter feito algum), mas às vezes se fazia um Laica-reel (não me pergunte daonde vem onome que eu não sei). O Laica-reel é usado principalmente para longa metragens, para evitar que alguma cena seja esquecida. O Laika-reel não é nada mais nada menos que a filmagem um storyboard absolutamante detalhado editado sobre a trilha sonora antecipadamente gravada. $\grave{A}$ medida que as cenas animadas ficavam prontas, substituiam as cenas "fixas" do Laika-reel (muitas vezes, primeiro ainda em pencil-test e depois, com as cenas finalis).

ML - Quem era o responsável pelo sincronismo com o som? Quem fazia as fichas de animação?

J - As trilhas sonoras pé-gravadas eram passadas para "óptico", ou "magnetico" $35 \mathrm{~mm}$. perfurado $E$, então, quem se incumbia de decupá-las era o editor do filme, que geralmente pertencia à equipe, mas também podia ser um free-lancer.

As fichas de animação eram feitas pelo diretor do filme (geralmente eu) dando dicas de como cada cena e, as vezes, cada movimento deveria ser.

ML - Quantas pessoas tinha a equipe?

J - Ah!... Isso variou muito. No Leo Pastro, nós eramos quatro, ou no máximo cinco. Quando me tornei free-lancer eramos "eu só limitada". E por incrivel que pareça: assim terminou também... Minha equipe chegou a ter mais de 50 membros no tempo de "Vila Sésamo". Normalmente porém, compunha-se de 15 a 20 pessoas.

ML - Quantos animadores na casa? Quantos freelas?

J - Em tempos normais: dois animadores (eu e mais um) e, se fosse preciso, contratava-se tantos free-lancers quantos fossem necessários

ML - Quantos intervaladores? Quantos clean-ups?

J - Normalmente, um para cada animador.

Geralmente o intevalador também era o clea-nup.

Os Free-lancers tinham seus próprios intervaladores e clean-ups

ML - Na passagem para o acetato, fazia-se fotocópia ou filetagem?

J - A utilização de Xerocópias começou em 1961 com "101 Dalmatians" de Disney, mas só em meados de 1970 a novidade chegou ao Brasil (o Guy Lebrum foi quem primeiro a usou; depois o Walbercy Camargo e depois o meu estúdio - em 1972). Antes destas datas, tanto lá (USA) como cá a "filetagem" era feia à mão mesmo.

ML - Quem finalizava - mixava com o som? 
J - O montador, seguindo as orientações do diretor do filme.

ML - Em que mídia o filme era entregue?

J - No meu tempo não existia esse tipo de nomenclatura. Os filmes eram entregues em "cópias cinematográficas" $16 \mathrm{~mm}$.", ou "35 mm."; o som poderia ser "óptico",ou magnético.

Em tempo: Salvo erro, meu último trabalho como profissional, "Salsichas Seara", em 1993, foi entregue em "cópia Beta"

ML - Quando ouviu falar pela primeira vez que o computador poderia ajudar na produção? Pensou que isto ajudaria ou que criaria mais problemas? Conte a sua experiência.

J - O buchicho sobre computação gráfica começou a ficar mais forte na virada dos 1960 para os anos 1970. Mas a gente via só via algumas imagens fixas, de qualidade bem sofríveis.

Aí surgiu nos USA o Bob Able com uma magnífica série de filmes gráficos que na verdade eram feitos com recursos totalmente cinematográficos (conhecidos como "luminatics"), e eu fui buscando assimilar a técnica, tentando criar imagens no mesmo estilo (muitas delas usadas em vinhetas da Rede Globo)

Para ser muito sincero, depois de assistir "Tron" e ver um monte de "demos reel" que vieram dos EUA, eu acreditei que as imagens digitais jamais teriam qualidade para se igualar ao cinema...

Hoje em dia, eu costumo dizer em minhas palestras que eu nunca fiz um filme em computador, mas que todos os nossos filmes gráficos (dos quais me orgulho) sempre foram feitos "com-puta-dor" - quadro a quadro - imagem por imagem - efeito por efeito - cor por cor - detalhe por detalhe - sofrida e penosamente, mas... sempre usando o velho (e querido) processo Cinematográfico, que hoje é só história. 


\section{APÊNDICE B - Transcrição Entrevista RIBAS}

Entrevistado: Walbercy Ribas Camargo (W)

Entrevistador: Maria Luiza Dias de Almeida Marques (ML)

Local: São Paulo- SP

Data: 20 de agosto de 2013

Duração da entrevista: 148 min

ML - Qual a sua formação, o que levou à animação?

W - Eu comecei a trabalhar com animação com 16 anos; com 16 e meio eu fiz o primeiro filme pra televisão, fui bastante precoce, fiz um filme pras Lojas Pirani; naquela época, o mercado fervia de novidade e havia uma carência profissional como sempre há carência profissional no Brasil, e de repente eu comecei num estúdio de animação chamado Lynx Filmes, era uma produtora grande que fazia filmes ao vivo, mas tinha o departamento de animação. De repente, eu entrei lá fazendo arte final, e, em três meses eu fiz o primeiro filme da minha vida, inteiro, quer dizer, por completo;

Essa época no Brasil existiam grandes diretores, que tinham saído da Vera Cruz e trabalhavam ali. O curioso é que nós trabalhávamos no table-top com o Chick Fowle, que foi um grande diretor inglês, e outros profissionais que estavam começando na época, eram praticamente alunos dele.

Diretores da Vera Cruz na Linx. Na truca Chick Fowle. Eu comecei aí muito novo, fazia colegial clássico, gostava mais de literatura e filosofia do que matemática e química ou biologia, e eu terminei o clássico e ia começar a fazer a universidade, só que na época, eu não tinha dinheiro pra fazer faculdade, né, e não existia nenhuma faculdade em que eu me interessasse, porque eu não queria ser engenheiro, médico, advogado, dentista, nada disso, eu queria ser artista somente, né, e o artista já nasce com a sua universidade pronta, ná, ele vai só desenvolvendo ela, né, que é um talento, a universidade da gente é o talento que deus dá pra gente, né, você nasce com talento. É uma coisa meio inexplicável e aí começou a surgir a FAAP, na época, só que a Faap era uma faculdade inatingível pra pobre, né, acho que até hoje, né? $\mathrm{E}$ aí eu não ia fazer faculdade, né eu já estava me envolvendo cada vez mais com animação, eu sempre fui uma pessoa de família muito humilde, vim de fazenda, nasci em fazenda, e eu não tinha condições de fazer faculdade, eu parei pelo clássico mesmo, e continuei minha vida profissional, e eu achava que era mais importante, e.. que eu tinha uma inquietude natural, eu queria fazer animaçnao revolucionária, eu não gosto de animação quadradinha, aquelas animações que tinha na época, pica-pau, tom e jerry, eu odiava, né, embora eu goste do tom e Jerry, eu acho maravilhoso, pica-pau, eu já achava meio...

...e eu acompanhava as animações americanas da UPA (04:04:17), que fazia aquela coisa...o grupo que saiu da Disney, pra revolucionar a animação nos EUA. Só que a animação que mais me influenciou foi animação da antiga luguslávia, e, acho que onde hoje é a Sérvia, e, a Tchecoslováquia, hoje, República Tcheca. Eu me identificava demais com aqueles trabalhos.

Na Rua Augusta existia, onde é o Espaço Unibanco, era o Cine Bijou, e eu ia assistir as sessões de animação que vinha do leste europeu, e eu ficava emocionadíssimo com aquilo lá, eu falei, essas coisas que eu quero fazer, acho que é muito mais pra cabeça do que pras mãos...

Eu gostava muito do Dusan Vukotic, que era um diretor iuguslavo espetacular, eu também gostava muito do Karel Zeman, que não era animador, mas era um diretor de filmes ao vivo, mas que fazia verdadeiras loucuras, né, tinha o Jri Trinka, com as animações de quadro-a-quadro, que era um gênio, eu visitei o estúdio do Jri Trnka; eu estive em Praga duas vezes, visitei o estúdio pela UNICEF, eu estava com a UNICEF, e curioso quando a gente viu exatamente os filmes que eu via quando era moleque, com 16, 17 anos, eu vi 
aquilo lá no museu, eu fui a pessoa que mais me emocionei, porque as pessoas que estavam comigo não sabiam de nada, mas eu sabia que aquilo tinha sido referência pra mim naquela época, e eu acho que é nesse tipo de referência que a gente tem que grudar neles desde cedo, se você quiser pegar isso depois de uma certa idade, eh, a interferência psicológica, ela age de outra maneira; quando vc tá começando e vc tem um certo encantamento, vc tem que se fixar um pouco nesse diapasão, nessa vibração que vai ter, entendeu, o seu sentido no momento de você estar se descobrindo.

Eu sempre fui uma pessoa muito sozinha, nunca tive pai, mãe, alguém que falasse "meu filho, siga este caminho", eu segui pelo faro, pelo sentido, né, nada do que eu fiz foi me baseando em alguém ou em uma referência que me propôs um caminho, entendeu? Eu fui buscando o meu caminnho artístico sozinho.(07:08:12)

$E$ aí, eu assisistia esses filmes e ficava muito animado na época, aí eu comecei a fazer os primeiros experimentos, em 1970, 1971, eu fiz um comercial pra Santista, eu usei um pouco dessa, eh, não é estilo, mas dessa linguagem, e aí eu estourei com o Barata Rodox (07:31:08), que eu fiz o barata Rodox e foi um sucesso aqui e lá fora também, um modo de dizer, porque eu ganhei o primeiro filme da minha vida que foi em Veneza, prêmio de animação no festival de Veneza de publicidade, e aí eu comecei a sentir que havia um... que eu tava me identificando melhor com essas coisas que eram possíveis de serem feitas aqui, lembrando sempre que eu nunca parti pra fazer filme de curta-metragem, essas coisas, porque, curta-metragem, nunca tive apôio nenhum, em época alguma, hj em dia já é diferente a coisa é um pouco melhor, mas naquela época seria impossível ficar fazendo curta-metragem, meu sonho era viver de animação artística, né, de arte mesmo, mas eu sempre fui pobre não tinha condições de gerar lucro e viver parado pra fazer curtametragem, e o que eu fiz?

Eu tentei aplicar tudo isso que eu gostava, eu apliquei na publicidade, porque a publicidade, mal ou bem ela te paga e você sugere pras pessoas da agência fazer um trabalho mais de vanguarda (08:32:11), e aí eu fiz a Barata Rodox, e fiz alguns outros e comecei a me desenvolver, até (eu tô só pontuando aquilo que foi sucesso) ... nesse meio do caminho eu fiz alguns trabalhos que eu considerei interessantes, mas o sucesso seguinte foi calça USTOP, foi justamente uma revolução, porque até então todo mundo usava "calça faroeste" chamava e aí foi a introdução do tecido Indigo-Blue na calça jeans, faroeste, fez um sucesso incrível o filme, foi praticamente, detonou a empresa, que é a Alpargatas que fazia isso, aí. Outros clientes, na época peguei tb outros clientes interessantes, que eu consegui alavancar um "plus" na vida deles, sabe, outros clientes que eu fazia coisas mais revolucionárias.

ML - Quais agências?

W - A USTOP é da Thompson, Barata Rodox era Standard, e fio Santista, que era o primeiro que eu experimentei, era Núcleo Propaganda, essa agência não existe mais.

E depois eu fiz vários filmes interressantes, é evidente que nem todos dá pra fazer experiências, porque nem todos os clientes são abertos a experimento (10:00:00), e, a partir da USTOP, eu fiz o filme da SHARP, eu recebi um convite pra fazer um filme pra SHARP, que foi onde realmente eu achei que foram os 10 melhores momentos da minha vida, foram 10 anos, mais ou menos 10, 12 filmes da SHARP e que foram marcantes na publicidade, e partindo de uma produtora, não partindo de uma agência, tudo era feito no estúdio, evidente, mas a idéia inicial saía do estúdio, não vinha da agência pro estúdio, e tudo saía do meu trabalho, e foi quando eu me identifiquei muito mais com o que eu fazia, um trabalho mais de vanguarda, mais criativo, e algumas coisas surreais, então eu fiz "o Som Colorido" (11:04:00) que foi o primeiro filme e apareceu um conjunto chamado "A Cor do Som", e foi um sucesso incrível, eu fiz o SHARP 1 , depois o 2, que foi com uma música do Stanley Black, que era o filme dos cavalos, ficou todo mundo maravilhado com o trabalho, é, crítica pra todo lado, gente falando do trabalho pra todo lado, ganhei muitos prêmios no exterior, em Tókio, NY, foi uma fase bastante criativa. (11:48) 
Nesse ínterim, nesse miolo, eu fiz também o Bebezinho da Johnsons, né, depois o Homenzinho Azul, foram vários, 10 anos de homenzinho Azul, depois eu fiz o Faber Castel, com a música do Toquinho, agora, esses trabalhos todos, não fui eu que desenvolvi, vieram da agência e eu desenvolvi, a idéia original, o brieffing veio da agência e eu desenvolvi o trabalho. Mas os Sharps, todos, o brieffing, a idéia a criação, o desenho, a animação, tudo eu é que fazia. Era um misto de animação, table-top, com grafismo, eu me identifiquei bastante com esse trabalho. $E$ depois eu continuei fazendo trabalhos comerciais, e epois houve uma decadência total, passados uns dez anos, mais ou menos, de 1978 a 1988, ou até 1990, até a entrada do Collor, quando o Collor entrou a miséria se estabeleceu. Então, até 1990, assim, eu me lembro que eu fiz o filme da Nova Era, até então os filmes eram muito bem pagos, dava gosto de trabalhar, porque, quer queira, quer não queira, no mundo capitalista o que fala mais é o capital, né, se vc não tem dinheiro pra trabalhar, você não paga nada, não paga dívida, cê entra em depressão, né? $\mathrm{E}$ a gente não teve esse hábito que passava em muitos países socialistas, né, se administrava a miséria, né?

Até pra se fazer um trabalho artístico vc precisa de tintas boas, (13:36), telas boas, se quiser pintar, e animação é um trabalho altamente tecnológico, vc tem que ter muitos materiais, material importado, tudo, é impossível vc fazer este trabalho sem gastar esse dinheiro, sem ganhar dinheiro, e o homem é ambicioso, o ser humano em geral é ambicioso, ele se sente bem quando ele conquista, né, os bens materiais são importantes nessa conquista.

Então eu acho que eu me identifiquei bastante nessa fase, até os anos 90, depois, as coisas começaram a cair, mas, depois que o Collor entrou foi um arraso total. (14:14) Realmente as coisas mudaram, e foi quando começou a entrar o vídeo.

Voltando um pouco, quando eu fui pra animaçao, eu tinha amigos que, por coincidência, tinha um vizinho, eu chamado Eli Barbosa, que faleceu recentemente, ele viu que eu desenhava, ele falou "vou levar você fazer um teste lá na Linx Filmes, eu fiz o teste e entrei; lá eles eram animadores profissionais, e eu não; tava lá, o Ruy Perroti, o Daniel Messias, o Marcello Tassara, no Table Top. Eu cheguei como franguinho lá, e comecei a fazer traço, essas coisas todas e, era tanto trabalho, que eles jogavam pro ar, e, quem pegar, pegou, faz o filme. Foi quando eu fiz o trabalho da Pirani, foi aí quando eu comecei a fazer animação.

Eu acho que eu entrei na animação, muito mais por necessidade de sobrevivência, do que porque eu amava animação tanto assim. Depois que eu passei a gostar, entendeu? Era muito mais pra ter um emprego em desenho, né, do que paixão por animação.

ML - Eu gostaria de saber como era antes e como o computador transformou o cotidiano no estúdio.

W - Acho que uma das pessoas que mais pode te passar os detalhes sou eu, porque, até em matéria de som, a gente montava som com gilete, as montagens de efeito de som, a gente montava frasezinha, efeitozinho, tudo com a gilete, e montava a fitinha,

ML - Preciso esticar esta parte, pensando nesse período em que vcs tinham uma carta branca do cliente pra fazer o que quisesse, não consigo imaginar outro artista da publicidade com tanta liberdade...

W - Eu tinha dois concorrentes, mas não tinha essa volúpia.

ML - Quem eram os seus concorrentes?

W - Eram o Daniel Messias e Luís Briquet, só que eles eram... o Daniel Messias também é criativo, ele tinha vontade de fazer coisas, mas eu tava sempre na vanguarda, eu tava sempre fazendo coisas novas, sabe, é até chato falar isso, mas algumas pessoas que não gostavam de mim, faziam trabalho com ele que era parecido com o meu, então, em vez de vir fazer comigo, eles não queriam fazer comigo, não sei por quê razão, sabe aquela coisa, 
dois bicudos não se beijam, então às vezes a pessoa está numa agência, tem um espírito artístico e ele não quer fazer com você, porque, existe alguma coisinha na alma d'a gente que se conflita, aí ele pega o trabalho e fala pro outro " faz mais ou menos como isto daqui", vai por este caminho, e até acaba magoando a gente, podia acabar dando um trabaho bem legal. Mas ele fez também trabalhos bonitos, ele fez trabalhos bonitos. (18:51) O Briquet, já era mais quadradão, mais conservador, o Briquet nunca foi um bom artista. Ele era um bom empresário de animação.

A gente tem que estar preparado também pras coisas ruins, não só pras coisas boas, e a gente tem que jogar este raciocínio lá pra frente. A gente não pode ficar achando "agora acabou tudo pra mim". Hoje eu vejo a situação que havia no passado e não posso ficar falando "aquela época era boa para mim", não! A época boa pra mim é hoje, não é a passada. Pegar o bonde da Computação gráfica não é querer ter pego o bonde: tinha que ter tido dinheiro pra pegar o bonde. Tinha que ter tido gente junto. Determinação pra pegar o bonde da computação, e não é fácil, muitas vezes, mesmo vc pegando um bonde, vc fica a reboque de outros. Então, não é ... o Briquet também acabou o estúdio, o Daniel Messias também não tá fazendo mais nada, parece que parou, se aposentou, ele é uma pessoa um pouco difícil de tratar, né.

Eu sempre tentei me destacar pela criação, pelo vanguardismo, o Daniel Messias é muito competente, eu gosto do trabalho dele também, mas o Briquet tá abaixo dele, abaixo de nós como vanguardista, mas também tem um bom estúdio, só que quem fazia animação não era ele, aqui não: aqui eu fazia a animação. Briquet era mais pra negócio que pra artista. Eu tô sentado na mesinha até hoje, desenhando e planejando o filme. então, essa é a minha veia, né? O Desenho animado está ruim, mas eu não vou largar o desenho animado pra vender sabonete, iogurte, porque eu preciso levar dinheiro pra casa, eu vou morrer com o desenho animado; se vc é um artista plástico e não tem dinheiro pra comprar a tinta VanGogh, compra a tinta feita no Brasil e continua pintando; o talento continua, a tinta mudou.

Mas, o que leva a pessoa a buscar o novo é a inquietude natural dela, tá dentro de você, vc não aprende na faculdade. Vc pode adquirir convivendo com pessoas do seu tipo, da sua sintonia. Nós somos um produto do nosso meio, o homem é um produto do meio. Eu sou uma pessoa que me sinto incomodado se tiver que ficar parado, em casa eu não fico, eu fico fuçando, fazendo projeto. Esse é um pouco do meu espírito.

ML - Eu acho que deveria ser natural que, vamos dizer, esses três estúdios [em questão, para a minha pesquisa] fossem os que...

W - Pioneiros...

ML - Que abraçassem e continuassem na computação...

W - Mas não foram, entrou gente nova no mercado; o problema é o seguinte: a computação gráfica precisa de dinheiro (25:51), eu digo o seguinte: se vc é filha de um industrial, de um produtor de soja, de um milhonário, tá sobrando dinheiro na família, vc vai fazer um curso na Cal Arts, nos EUA, aí vc volta com um tremendo conhecimento em computaçnao gráfica, vc vem aqui, vc monta um estúdio de computaçãao gráfica, e vc mete propaganda em cima das pessoas, vc gasta dinheiro com você, você traz todas as máquinas que você conhece, que vc domina, tráz software, pega gente, tráz uma ou duas pessoas com você de fora, né, é o dinheiro, quer dizer, tem um momento em que a base artística sua já não serve mais pra nada. o que serve é poder do capital. quem tem dinheiro, então eu te explico toda cronologia que aconteceu na época, essa mudança toda, eu vivi essas coisas todas, quando começaram a existir os primeiros plotters, não eram nem computadores...

ML - voltando um pouco, quem calculava o orçamento dos filmes? Como era a distribuição da verba? QUanto era para pra equipe, quanto era material e quanto de capital de giro da 
empresa?

Walbercy - eu que fazia tudo, nessa época, eu tinha alguns animadores argentinos aqui (27:49), eles tinham fechado o estúdio deles em Buenos Aires e tinham vindo pro RS, pra Porto Alegre, o Arnoldo Cirilli e o Jorge Benedetti, eles eram um de Rosário e o outro de Buenos Aires vieram da Argentina e foram pra Porto Alegre, montaram estúdio em PA, mas viram que não tinha futuro, vieram aqui pra São Paulo e me conheceram, eu convidei eles pra virem pra cá; o que eu fazia nessa época? Eu pegava um filme "x" e fazia o filme em três partes: uma parte pros animadores, outra parte pra administração, e uma parte de lucro pra firma. Especificamente não tava dirigido a quantos funcionários iam fazer o filme ou não; todos tinham que fazer o filme. Então ficava assim: lucro da firma era $1 / 3$, gastos com a firma era $1 / 3$, e $1 / 3$ era pro animador. A base bem socializada;

\section{ML - A parte da administração era pra comprar os materiais?}

W - Isso, com $1 / 3$ a gente comprava tudo, acetato, tinta, papel, grafite, xerox, tudo essas coisas que existiam, ficava desta maneira, economicamente pré-estabelecido. (29:25)

Com o passar to tempo, essas coisas começaram a ficar muito caras, a margem de lucro era pequena. Você tem que fazer muitos filmes pra ter uma margem de lucro boa. $E$ muitas vezes, se vc não tem um lucro, mais ou menos interessante, você deixa de... você não se reinventa. Você fica à margem do doméstico, quase, o dinheiro que eu levo pra casa, e com uma empresa vc acaba enfraquecendo, se vc não tem uma margem de lucro boa, vc não consegue reinvestir, não consegue comprar equipamento, ou, pesquisar o que está acontecendo, o que vem de fora, porque tudo infelizmente vem de fora, nada no Brasil nasce aqui, só as pessoas; aí, nessa época os argentinos quiseram voltar pra argentina, animação já não estava tão interessante, e as estruturas vão esmorecendo, isso aconteceu em qualquer área do mundo, não deu mais dinheiro: pára. Só os loucos permanecem insistindo nessa área de animação. E a gente sempre fala: o homem é pirracento...

Existem outros sabores na vida, a vida não é só dinheiro, no momento em que vc não se envolve tanto com dinheiro, vc começa a se sentir mais humano, tem que sobrar tempo pra você viver, coisa que a animação, ela te consome tanto, que não tem tempo de você viver, existe uma faixa da vida da gente que a gente é tão consumido, trabalha tão intensamente, o nervoso que vc passa em publicidade é terrível, o nível de exigência que a gente tinha aqui, qualquer poeirinha, não podia entrar no filme, tudo era isolado, tudo era limpo com luvinha branca, então, é um terrorismo que se pratica contra a mente, e vc acaba passando esse terrorismo pros funcionários, fica todo mundo sofrendo feito doido, porque o cliente é o ser supremo, é o zeus, ele que tem que aprovar. (32:29) Muitas vezes o cliente não tá nem aí, não entende absolutamente nada, nem viu aquilo que vc tava vendo, mas vc Maluco e perfeccionista, vê coisas que ninguém vê, mas às vezes alguém vê, o cara da agência... Você percebe que a profissão é extremamente desgastante, consumidora, e vc chega à conclusão que não leva a nada, porque ninguém reconhece o seu trabalho, o que vai pro ar é a marca do cliente, não o seu trabalho. Alguns reconhecem, alguns que se sensibilizaram, descobrem que foi vc quem fez; mas a única coisa gratificante nessa área, sem medo de errar, é ganhar dinheiro. (33:20)

Só que, aí eu acho que entrei com uma certa sabedoria, que era a minha diferença dos outros: eu ganhava dinheiro, mas eu usava a publicidade como meu laboratório de experimento, e eu procurava colocar na publicidade tudo aquilo que eu achava que era interessante colocar, em termos de arte, e não de fórmulas publicitárias mágicas, mas eu sabia que, no momento em que vc mexe com o lúdico, com o imaginário das pessoas e com a fantasia, e quando vc liga a televisão e via aqueles comerciais, eu sei de histórias maravilhosas, de pessoas que tinham assistido eses filmes, e ficavam emocionados e não sabiam porque ficavam emocionados, mas se emocionavam, porque vc tinha atrás uma música, que vc pesquisava fantasticamente, vc tinha uma parte gráfica interessante, de cor, de magia, de metamorfose, dque ia acontecendo, e que pro público, até aquele momento, era novidade. (34:34) 
Outra coisa que é saborosa também, é vc estar vendo uma coisa que vc nunca tinha visto, esses fatores foram fundamentais para que eu me destacasse como uma pessoa mais de vanguarda.

Só que eu vivo no Brasil. e eu costumo dizer, confessar pra vc, que, país pobre, onde pouca gente faz alguma coisa, aquele que faz é perseguido. Ou é perseguido porque não te passam mais trabalho, passa a ter inveja de vc, "por que acontece com ele e não comigo?" Existe uma coisa dentro da gente que, além da magia, existe o sobrenatural; às vezes eu mesmo me surpreendo com artistas com um trabalho maravilhoso, eu digo "eu gostaria de ter feito esse trabalho"; não de animação, de artes plásticas, de pintura. Então eu acho que essa busca, eu continuo tendo. (35:50)

Pra animação, por exemplo, eu acho que não tenho mais espaço de fazer aquilo que eu gostaria de fazer, vc fala assim, "vc vai cair no trivial". Hoje, nós estamos fazendo animação trivial, aquela que agrada o momento, tanto em cinema, como em publicidade, alguém pergunta: "vamos fazer um negócio louco?" não existe mais, raramente aparece um trabalho "olha, tá bem feitinho, bonito trabalho", mas não tem mais aquele impacto que tinha, inclusive eu peguei uma época, não foi só a minha época, existia produtoras de filme ao vivo que faziam trabalhos também revolucionários, que faziam trabalhos excelentes ao vivo, e essas pessoas todas pararam hoje, todos pararam. Eu me lembro de trabahos super interessantes; (36:46)

Essa fase dos anos 70 até os anos 90 foram os anos mais lindos na publicidade brasileira. Depois, pifou. Parece que apagaram as luzinhas, muitos pararam, muitos morreram, muitos abandonaram, foram fazer outra coisa.

Quando vc tem a chance de fazer outra coisa, "vamos sobreviver disso e acabou", eu acho que o link não dá pra desplugar, é muito difícil... ou a gente não faz mais quase filme publicitário, tem feito muito mais... coisa, durante muitos anos fiquei fazendo muitas coisas pro exterior, né, durante 20 anos fiquei trabalhando pro exterior, uma hora cansei, e aí é onde tem uma fonte de renda boa, dólar, mas aí cansei; fiz algumas coisas pra Londres, fiz muita coisa pro México, fiquei 20 anos trabalhando pro México, fiz Chile, Venezuela, Argentina, fiz coisa pro Canadá, Europa, Portugal...(37:58)

Mas tem uma hora que não é só o dinheiro. Dinheiro não é tudo na vida, eu tb tô cansado. acho que tem que dar um tempo pra gente também. Tem que achar um tempo pra você "amanhã tem uma exposição de tal pintor", então eu vou lá.

ML - Quem definia o Lay-out dos filmes? (40:15)

W - Sempre eu.

ML - Quem fazia a decupagem e o story-board?

W - Quase sempre, eu. Houve uma época em que teve uma pessoa que fazia, mas é o estilo do estúdio, o estúdio tem uma personalidade. No momento em que todo mundo faz tudo, perde a personalidade, passa a ser uma empresa, deixa de ser um estúdio. Estúdio é uma coisa, empresa é outra.

Aqui no Brasil é tão difícil vc ter a admiração das pessoas, por estar na publicidade, eu tive muita admiração das pessoas, por fazer publicidade, eu sempre fui muito concentrador, é muito difícil delegar. Até hj é difícil, mas eu tô delegando pouco a pouco pro meu filho, de trinta e quatro anos, vc fala, "pô, mas ele já devia ter delegado desde os 20 anos de idade", mas não é assim. Há um processo de amadurecimento de hoje, que a gente tinha mais rápido antigamente, porque a gente era obrigado a fazer, ou a gente fazia ou morria de fome. (43:41)

Nós temos dois longa-metragens aqui, que estão em mais de 70 países. $E$ nós vamos partir pro $3^{\circ}$ longa, se deus quiser, mas a fase da publicidade que a gente fez foi revolucionária. As pessoas gostavam demais do que eu fazia, mas, ficam com o pé atrás, as pessoas achavam que era muito louco, que eu devia consumir uma droga desgraçada, que eu devia ter alguma coisa de budista, mas eu sempre fui uma pessoa extremamente comum. 
O importante é a cabeça, não é como vc se veste pros outros. Eu sempre fui aquela pessoa que, vinha a oportunidade, eu fazia, traduzia em realidade uma oportunidade que vinha, pra eu fazer um trabalho, dentro daquele universo que me era permitido na publicidade, porque tabém tinha seus limites, né?

\section{ML - Algum desses filmes (SHARP) o senhor teve que refazer?}

W - Teve um capítulo dentro dos filmes da Sharp, interessante, que, os filmes da Sharp, quem me chamava pra dar os filmes era uma pessoa de tendência esquerdista, socialista, mas ele nunca falou "Walbercy, põe uma bandeirinha vermelha no canto" nunca precisou falar, porque o subconsciente já te revela algumas informações interessantes, né, quem observa, observa. Então, nós vivíamos no regime militar, e quando eu fiz o filme "Som Colorido", eu tinha colocado muita coisa só de fantasia, coisas mais oníricas, aí no segundo filme, eu falei, vou fazer uma coisa mais impactante, foi quando eu tinha viajado pro Peru, fui pra Machu Picchu, um lugar muito lindo pra conhecer, místico, então eu trouxe um pouco da essência da coisa peruana, coloquei um mural peruano no fundo da primeira cena, que tem o homem pegando fogo, com cadeado na boca, e lá em Brasília se sentiram incomodados, porque eu usei uma música daquele russo Stanley Black, ele não era russo, mas era uma música que chama Steps, quem fez a orquestração foi Stanley Black e era uma música bem "AHHH", um coral com uns 100 caras gritando lá, e aquilo impressionou muito, ficou todo mundo de orelha em pé lá. (47:18) E aí o terceiro filme, que eu tava fazendo todas as crianças do mundo indo embora pro céu, brincar com as estrelas, e lá em Brasília, o Simonsen tava lá no Ministério da Fazenda e mandaram um soldado ficar na frente da televisão pra ver o filme da Sharp, quando passasse o filme na televisão chamasse o homem pra ver o filme da Sharp. O Simonsen queria ver os filmes também, mas ele não tinha nada a ver com o regime militar. Mas ele queria ver porque ele admirava. E aí começaram a ver o filme e veio aqui um tal de general Pimenta, mandaram pra cá o General Pimenta, pra ver que filme a gente tava fazendo; ele veio aqui porque ele se comunicou com a Sharp, a Sharp se comunicou com a House deles, o ministério tinha uma house, aí vieram aqui, veio o general pra ver qual era o próximo filme. Aí o cara viu aí que todas as crianças do mundo estavam fugindo do mundo, da Terra pra ir pro céu. pra ir pra um outro espaço brincar com as estrelas e com lua, ficou um filme bem legalzinho, e aí o cara achou que não tinha nenhum problema, deixou o filme passar.

Depois eu continuei fazendo, eu fiz outros filmes interessantes, aí, quando vc começa a fazer sucesso, começa a incomodar outras agências, querem dar opinião, e alguém fala "agora eu quero fazer um filme com tal pessoa... aí a coisa começa a degenerar, e eu sou um pouco... eu descarto um pouco as coisas, se não é pra fazer comigo, não será, então vá fazer com quem vc quiser. Eu tenho capacidade de ressucitar a minha arte. Quando vc tem capacidade, vc muda o caminho, muda o foco, vc consegue lidar com isso. Muitas vezes a pessoa na agência dá o brieffing, "o personagem $X$ é assim, assim, mas quem desenhou o personagem fui eu, o brieffing é do cara, eu nunca neguei isso. Mas aquele desenho que foi pro ar é meu. Então, tem um pouco dessa ciumeira, na publicidade tem muito ciúme; (51:39)

Sobre a animação, a gente continua fazendo, quando eu comecei a diminuir a parte de publicidade, meu sonho era sair do 30 segundos para uma hora e vinte de filme, e eu fiz isso, consegui fazer, embora o que eu fiz não é o que eu gostaria de ter feito, porque eu estava me dedicando mais à criança, a criança é eterna, e se o filme pra criança estiver bem feitinho, ele vai embora. Eu, na realidade, gostaria de ter feito um filme que nem o The Wall, com as músicas do Pink Floyd. É nessa linha de filme que eu gostaria de ter feito, mas até lembra um pouco aquelas coisas que eu fazia com a Sharp. Mas é impossível fazer isso no Brasil, por que? porque todo investimento num longa metragem aqui é de lei de incentivo fiscal, cê tem que passar pela ANCINE (52:34), ninguém vai aprovar um filme desses. (53:49)

ML - Vocês faziam algum tipo de animatic? 
W - Não, nunca fizemos animatic. Raramente, não era a prática fazer animatic. Era na confiança, viu? la ver o filme pronto.

ML - Quem era o responsável pelo sincronismo com o som? Quem cuidava da questão sonora nos filmes?

W - A preocupação com o sincronismo era tudo da gente, eu que era o diretor, só que a manipulação de sincronizar os filmes, na realidade era o seguinte: a gente recebia o som pronto e tinha que fazer a divisão sonora, né? Por sílaba, e tinha uma pessoa que fazia isso um menino que fazia essa divisão. O som vinha em magnético, vc passava pra ótico no laboratório, depois revelava e depois aparecia a banda sonora de lado, o que acontece? você visualmente você vê a banda sonora. Tinha um departamento que cuidava do laboratório externo. A Líder.

ML - Quantas pessoas tinha em cada equipe?

Walbercy - a minha equipe sempre foi uma equipe única, não tinha equipes divididas. Você dividia um filme, cada animador fazia um filme, mas a equipe de conclusão do filme era uma só, né, que fazia esse processo. Eu tinha equipe de animador, equipe de cleaner, equipe de artefinalista, equipe que cuidava da parte de laboratório e equipe de filmagem. Tinha várias equipes aqui dentro. A média de pessoas trabalhando aqui era de 30 a 40, 35 pessoas, a média. Uma média de 6, 7 animadores, todo mundo era fixo. Hoje é inviável, não tem condições, mas tem alguns Mcos por aí que tão com equipe grande.

ML - Quantos assistentes?

W - Em geral, dos 7 animadores, tinham 4 assistentes, a média, faziam intervalação e cleanup também. Sempre às vezes tinha jovem entrando, garotada entrando,

ML - Na passagem do desenho no papel para o acetato, qual era o processo?

W - Na transferência, até uma certa época, a gente usou o nanquim, né, até 1971, a gente usava nanquim direto, até mais, aí a partir de 1972, já comecei a fazer tudo na xerox, não tinha mais a mão. Só pintava o acetato.

Comprei uma máquina de xerox Hank Sintel era própria pra isso, não era xerox de fazer cópia, não. Máquina grande, quase do tamanho desta sala. Eu vendi uma perua Kombi, uma câmera, várias lentes, mais um refletor, tudo pra comprar essa... vendi todo o meu parque de filmagem ao vivo pra comprar essa máquina. Por isso que eu falo, muitas vezes, você tem que dar o passo, mesmo que você vá claudicar.

[A asistência técnica] era tudo muito primitivo, muito simples pra não dar certo, o problema maior eram umas placas de ... não me lembro o nome que se falava, umas placas que, imantadas que, o pó aderia só no traço do desenho, aí você transferia pro acetato através de eletricidade estática, ozônio que tinha, só preto-e-branco... Depois começou a aparecer... o pó que era o segredo, começou a aparecer pó azul, pó vermelho, tudo importado, tinta importada, acetato importado, tudo, nada é nosso, nós só temos aspirina.

ML - Como vcs resolviam quando dava algum problema?

W - Raramente dava algum problema. Nunca deu problema. Depois eu comprei mais uma. Acontece que ela tinha um fole que vc aumentava, diminuía, fazia tudo com ela. Zoom que era impossível fazer na câmera, você fazia com a ampliação dos desenhos, ampliação das embalagens, não que você fazia lá e já saía no filme: você fazia lá, pra depois fazer a arte final, a arte toda, tanto é que a gente trabalhou muito com fotografia, fazendo zoom de fotografia, o Filme da Faber Castel (01:13), é uma outra historinha, que é quando surgiu o concorrente: quando surgiu o computador. A gente fazia tudo na Xerox, depois comprei uma 
outra, né, o que acontecia com o fole é que, de tanto abrir, tanto fechar, às vezes rasgava na ponta, mas a gente metia fita isolante e ia em frente, não parava. Nessa época, vc limpava com Tricloroetileno, o acetato tem que ser super limpo pra poder aderir a tinta, eu comecei a tentar fazer tinta aqui, não consegui, aí nós paramos de importar, começamos a fazer tinta latex, mas não tinha a mesma qualidade. A gente fez várias tentativas mas não deram certo, a tinta melhor era a importada.

A gente reutilizava o acetato, aqueles que tinham boquinha, olhinho, nuvenzinha, que tinha pouca área utilizada. Mas ficava marcado o risco da caneta, né, porque muita coisa, tudo que era feito em branco tinha que ser feito à mão. Branco, colorido, luzinha animada... oaerografado dava pra recuperar tudo.

Custava U \$ 1000,00 o pacote de acetato. Um dólar por folha de acetato. A produção era muita e só usava o importado, porque a transparência era melhor, eu cheguei a usar o nacional - o nacional era feito numa fábrica de capas e quarda-chuvas, o cara tinha acetato lá, só que vc olhava pra ele, só via bolinha. Se você colocasse 2 acetatos, o desenho animado já ficava amarelo, então tinha que importar acetato cristal original, porque a transparência dava aquela lucidez. O acetato já vinha no tamanho cortado, perfurava aqui.

ML - Quantas pessoas pintavam acetatos e faziam os traços de outras cores e efeitos?

W - Umas 10, 12.

ML - O senhor encabeçava? Fazia um de exemplo?

W - Sim, a orientação já vinha da animação, só que todas as cores, eu aprovava, eu aprovava os cenários, eu fazia cenários, eu fazia o story-board, eu animava, fazia o diabo. Mesmo assim, eu ainda era um pouco ditador, porque eu tinha que exigir das pessoas que fizessem bem feito, porque uma coisa é básica: você não consegue disciplinar um país, se não tiver alguém com pulso duro, vc não consegue educar.

Voltando: era uma loucura tão grande, que se vc tinha um risquinho no acetato, no aerógrafo, vc tinha que voltar pra mesa pra aeografar: aí, a máquina tava desligada, limpa o aerógrafo, pra corrigir um risquinho, no branco; era neurose, se eu não morri, de derrame cerebral, é porque Deus tá me protegendo.

ML - Vc tem os negativos?

W - tenho negativo dos filmes mais interessantes. Mas muita gente deve ter jogado fora,

ML - Em quel mídia os filmes eram entregues?

Walbercy - cópias $16 \mathrm{~mm}$, filme pronto, com som com tudo. Entregava prontinho. Você fazia em $35 \mathrm{~mm}$ e reduzia pra $16 \mathrm{~mm}$. Nós preparávamos aqui o material pra juntar com o ótico de som lá no labooratório. Aí eles pediam 40 cópias, 50 cópias, Coristina, por exemplo pedia 100 cópias, deve ser pro carnaval, que nem serpentina, rsrs. pra gente era uma grana, ganhava mais dinheiro do que fazer filme,

ML - O cálculo do orçamento já levava em consideração o número de cópias?

W - Não, o filme era uma coisa, cópia, outra. E a cópia, o cara is decidir depois da mídia, ele pedia o filme e depois via "onde nós vamos entrar com esse filme?" "vai pra tal lugar, então pede tantas cópias" ...

ML - A emissora de TV fazia a telecinagem?

W - É, passava por projeção, vc projetava, o cara refilmava lá, recaptava. Eu. na realidade não sei muito bem como eles faziam, se era uma kinescopia, tinha o kinoscópio que filmava 
novamente a imagem, não posso dizer exatamente, porque eu nunca vi pessoalmente. A TV, muitas vezes tá na nossa frente em tecnologia, que eles têm mais poder aquisitivo pra fazer essa inserção, mas eu não me lembro exatamente o que acontecia.

Então, o filme era entregue em $16 \mathrm{~mm}$ até 1990 , quando apareceu o vídeo, o vídeo pra animação, o vídeo já existia pra cinema, você filmar em vídeo, mas era tido como um deboche, filmar em vídeo era porcaria, só que, na hora que o Collor confiscou tudo, aí veio a hora da miséria: todo mundo começou a fazer coisinhas em vídeo, porque não tinha mais dinheiro, não tinha verba. Quem pagava US\$100.000,00 pra fazer o filme, passou a só ter US\$10.000,00 pra fazer as coisas. A televisão precisava de filme, o patrocinador precisava fazer filme, aí começaram a surgir as empresas de vídeo, e nós, consequentemente começamos a telecinar. Nós filmávamos em $35 \mathrm{~mm}$ e não fazíamos mais a redução pra $16 \mathrm{~mm}$. Fazíamos num Bureau de vídeo, eu não usava a Casabblanca, eu usava um outro lá na mooca, que depois acabou fechando...

(1:16:37) Aí, começou uma outra fase, foi um divisor de água (1990): morreu a cópia 16mm e começou a entrar o vídeo. Aí, nós fazíamos telecine do $35 \mathrm{~mm}$.

Até então, a gente continuava trabalhando com acetato, tinta, nankim, aerógrafo, todas essas coisas, só que o processo de laboratório começou a acabar. Era muito mais fácil vc transferir e entregar a cópia de vídeo, em U-MATIC. Depois que veio a fita beta, que era uma qualidade melhor.

ML - E o som vinha quando, nessa nova organização?

W - Quando você fazia o laboratório... aí que tá o negócio, Você levava o negativo original, no começo era assim: nós fazíamos cópia $35 \mathrm{~mm}$ íamos lá, e fazia a cópia já com som, mandava fazer o som junto com a cópia, e a cópia com som, vc passava pra vídeo.

W - À medida em que foram melhorando os equipamentos de transferência, de filme pra vídeo, nós passamos a melhorar a qualidade fazendo o seguinte: levando o som original, a fita gravada no estúdio - a fitinha 1/4, rolinho, não existia fita DAT. O cara na hora copiava. Aí vc levava o negativo original, você não fazia mais cópia: telecinava o negativo, transformava o negativo em positivo, você assistia lá, um tipo de máster, assim, você copiava o negativo e jogava pra máquina, aí vc tinha que ir na ilha, o que encarecia de um lado, mas compensava pela qualidade, pela limpeza do trabalho; Aí, as cópias já não tinha risco, já não tinha verde, aí, vc passou a ter um controle de qualidade melhor. Aí, lá na ilha de edição vc juntava o som com a imagem, aí, vc punha claquete. Isso, fizemos por vários anos.

Nós pegamos um filme pra fazer pra NY, e nós estávamos começando a implantar o computador, quando o Rafael tinha 14 anos. Eu comecei com 16 anos a fazer animação, ele com 14, começou a fazer a primeira animação por computador. Aí, eu comprei um computador chamado TOPAS (1993). Só que, tem um detalhe aí: eu lembro que eu falei pra vc que eu fazia os filmes da FABER CASTEL, pela idade do filme da FC dá pra saber algumas coisas aí, fazia tudo com fotografia, os lápis de cor eram fotografados, tudo animação em fotografia, animação de desenho, porém no produto era em fotografia. dá um trabalho medonho e a fotografia sai sempre uma fotografia, cada hora que dá um banho (de revelação), a cor sai diferente, o tom sai diferente, então não era muito feliz, por mais que vc caprichava, retocava tudo de novo, as fotos vinham pra cá, a gente retocava todas as fotos;

Aí, nós fizemos a ECO 92, na ECO 92, a gente estava fazendo a FABER CASTEL, foi quando nós fizemos uma produção com a VETOR ZERO (01:22:10), tava começando a VETOR ZERO, nós fizemos a parte da animação e eles fizeram a parte de produto já em computação gráfica, o lápis era computação gráfica. Esse foi o segundo FABER CASTEL, aí, nós estávamos comprando os computadores também; eles tinham comprado um computador que era da Jovem Pan, se chamava TDI, francês, eles tinham comprado da Jovem Pan e começaram antes da gente a trabalhar. Por isso que eu falei, a gente começou antes com o computador, enquanto a gente continuou com a animação tradicional, foi 
quando a gente começou a perder o contato. E aí, a gente comprou o TOPAS, e começamos a fazer animação, a primeira animação foi essa do COLGATE, pra NY, depois tem um outro menino chamado Rafael, ele e o meu filho começaram a trabalhar juntos, a gente começou a desenvolver várias coisas em computação, mas a gente não tinha muito interesse, era mais um elemento agregador, não era a nossa sobrevivência, não, era... era mais pra fazer embalagem, já fazia no computador; um produto, já fazia no computador, então ia agregar na animação; (01:12:29) e isso foi um fator que foi ajudando. Aí, foi um divisor de águas, porque, a partir daí, o que aconteceu? à medida que a gente ia evoluindo, nós extinguimos o acetato, nankim, a pessoa pra limpar o acetato, o líquido de limpar o acetato, extinguimos o negativo, a pessoa que cuidava do material de laboratório, a pessoa que fazia o ótico, a pessoa que filmava quadro a quadro, praticamente o departamento foi todo extinto. Pessoas que pintavam o acetato, tudo isso foi extinto gradativamente. Só depois que eu comprei um Sillicon, que foi uma verdadeira fortuna quando eu comprei o primeiro Silicon, aí as coisas começaram a acelerar. Nós começamos a fazer as vinhetas, assinaturas e produto com uma qualidade excelente, o primeiro produto que eu importei já finalizava tudo na máquina, eu não tinha mais que finalizar fora, fazia tudo aqui dentro; surgiu a DAT (01:24:56), o DAT a gente jogava pra dentro do computador, soltava o som, sincronizava direitinho e fazia tudo aqui dentro, a claquete, então daqui saía pra BETA, comprei ilha BETA, e saía cópia direto pro cliente, eu só tirava cópia fora, porque não tinha outra BETA pra copiar.

Aí, acabou negativo, acabou $16 \mathrm{~mm}$, acabou pintura, acabou tudo; Isso já era 1994/95, mais ou menos. Aí a gente começou a se adaptar com o computador, e já em 1996/96 já não fazia mais nada em ... Aí foi dissolvendo a equipe de animação também; você já não xerocava mais toda animação, isso já foi antes, que escaneava; aí você compra um equipamento melhor, você já não escaneava mais, pintava direto, eu comprei várois programas, Toons, da Itália, a gente pintava tudo no computador, a arte final foi tudo... a limpeza do trabalho, a qualidade... foi tudo abandonado, então essas coisas você não... são destruídas, né. Esses departamentos desapareceram. Aí, até um office-boy, ele ia embora, apareceu o motoboy. Esse é o problema, né, que são pequenos detalhes...

ML - Quando o sr. ouviu falar pela primeira vez que o computador podia ajudar nas animações?

W - Sim, vc sabe que tudo vem de fora, então eu acompanhava os livros, as matérias, e eu via lá algumas experiências feitas lá fora, e alguns artistas gráficos que faziam experiências com ploter, antes dos primeiros computadores vieram os ploters, que era um bracinhos que iam desenhando, uma agulha que vai desenhando, na memória do computador, eles desenhavam, esses plotters na realidade serviam pra fazer peças, de automóvel, alguém começou a adaptar pra animação, e o plotter vc usava muito pra fazer giro de câmera, essas coisas, entendeu? Vc pegava um ambiente, fazia no auto-cad, vc girava uma câmera, então o ploter ia produzindo essas coisas quadro-a-quadro, depois passava pra animação e vc redesenhava tudo, vc não usava diretamente aquilo, cê passava pro desenho, cê quer um giro numa sala com o desenho de um personagem pegando outro, a gente sempre teve essa vontade de fazer movimento de câmera, só que não existia a técnica da computação gráfica de fazer esses movimentos de câmera, então vc usava um ploter, pra vc, o ploter desenhava tudo, folha or folha, todo movimento de câmera com objeto, essas coisas todas;

Aí vc vai vendo que estão acontecendo essas coisas, fica a curiosidade, cê quer comprar, quer participar, quer saber quem tá fazendo, como é que tá, só que a vida do plotter foi assim: apareceu um plotter, dali a 8 meses já tinha o computador... O Daniel Messias usou o plotter; eu não cheguei a usar. A gente fazia às vezes com maquete, entendeu? Nós fazíamos a mesma coisa com maquete; A gente tinha um fascínio, a grande coisa da animação é mais ou menos como o Michelangelo fez o Moisés: ele achou tão perfeito que deu uma martelada no joelho e disse "parla!", né?

A angústia da gente como animador, como diretor era ver movimento de câmera em animação, era tudo parado, se quisesse mov. de câmera tinha que fazer tudo na unha, tudo 
na mão, quadro-por-quadro, um por um, desenho por desenho, objetos, cadeirinha, tudo tinha que ser feito $\mathrm{n}$ mão, personagem na mão, aí cê tem que fazer teste, girava e dava tranco, voltava e corrigia, faz com fotografia depois passa pro desenho, aí vc passava a limpo o desenho e estava ruim, corrige de novo, era um desafio o que vc fazia, vc estava se desafiando pra dar o melhor de si. O que eu acho fantástico nesse trajeto é que a gente tentava ir além do que as máquinas proporcionavam em animação, porque a máquina de filmar desenho animado era fixa numa torre, sobe e desce, e tem uma hora que desce e desce e quase quebra o vidro, então vc tentava fazer isso na mão, essa era uma angústia da gente da animação.

Aí, quando surgiu a computação gráfica, isso tudo foi possível, hoje uma câmera vôa, cê entra com a câmera onde vc quiser, acima da filmagem ao vivo, que a filmagem ao vivo ficou pra trás, a computação gráfica foi muito além do que a câmera ao vivo. Quando chegou isso tudo vc faz o quê? Rasga o passado! O passado, deixa na parede, uns quadrinhos aí, vamos partir pra isso.(1:30:39)

Então, eu comprei computador, gastei US\$ 180.000,00 num computador na época, computador não tinha nem placa, me enganaram, aí chegou a placa, entregaram a placa, eu peguei um equipamento que o Spielberg tinha, chamava PARALAX, tinha terminado o Jurassik Park $1^{\circ}$, que foi surpreendente, onde finalizaram uma parte do filme lá, e eu comprei esse equipamento também, e a gente finalizava tudo aqui dentro, só que vc ia numa agência, falar com o cara, as pessoas debochavam, "ah, vcs têm um Sillicon Graphics? "Ninguém tinha um Sillicon Graphics, só tinha um cara em SP, nós fomos os segundos a comprar; tanto é que, por exemplo, um negócio que passou sem a gente perceber, é como se fazia Pencil Test? Não existia teste de animação, Você flipava e "ahm tá bom", não dava pra filmar, até dava: filma, pra depois revelar e assistir o pencil teste. Quando o filme tinha verba a gente fazia isto. Só que eu fui o primeiro a importar um equipamento de Pencil teste na América do Sul, em vídeo, a empresa era Lion Lamb, a empresa que fazia o equipamento de Pencil teste, equipamento de quadro-a-quadro pra vídeo. Era vídeo quadro-a-quadro, não existia,

$M L$ - $E$ quando foi isso?

W - Se vc soubesse quando foi que o Frank Sinatra veio ao Brasil, a primeira vez aqui no Maksoud...

ML - 1980?

W - Acontece que o primeiro equipamento que eu importei, eu importei com contrabandista, e o equipamento ficou preso na alfândega; o Frank Sinatra veio, cantou no Maksoud, foi embora, porque, todo equipamento que ia fazer o show do Frank Sinatra estava junto com o meu equipamento, foi preso na Alfândega, e o cara não conseguiu desembaraçar, o Frank Sinatra veio, cantou, foi embora e o equipamento foi liberado depois de muita luta, depois de um ano; então, ficou na alfândega, normalmente ele zinabrou.

E eu comecei a usar o equipamento, só que teve uma, ele durou uns 3,4 anos, depois ele pifou, mas, quando a gene usava, tudo ficou lindo, vc filmava quadro a quadro e dizia, "deixa eu ver como a animação está, tá boa, mexe aqui, mexe lá"; deu uma mão de obra bárbara, foi quando começou a sessão do vídeo, que o vídeo começøu a aparecer, ele abriu um caminho importante, essa época do vídeo, embora ninguém gostava de filmar em vídeo, mas ele abriu um espaço interessante pra vc chegar próximo à computação gráfica.

Aí começaram a aparecer muitos softwares diferentes, competidores diferentes do mesmo software, mais barato, mais caro, e eu comprei esse esquipamento caro aí, foi quando a gente começou a fazer o trabalho, eu falo pra você, gastei uma grana preta, US\$180.000,00 é dinheiro, pra vc comprar equipamento, sabe, o primeiro foi usado, depois eu consegui ganhar dinheiro, eu fazia muito trabalho pro México, aí consegui comprar o segundo, computador, da Sillicon, o primeiro era verdinho, o segundo era roxinho, comprei o segundo também, e fui indo. Depois o custo caiu assustadoramente, começamos a fazer o Grilo Feliz 1, né, uma outra fase da vida, né, com a abertura das leis de incentivo fiscal, A Lei Rouanet foi a primeira, eu consegui pegar dinheiro pra fazer um sonho que eu tinha há 
mitos anos; eu peguei 30 minutos do filme e joguei fora, porque foi tudo feito sem tempo... aí, nós tivemos que reestruturar a história, aproveitamos uma boa parte, passamos a limpo muitos desenhos antigos e abandonamos todo acetato que já estava pronto, meia hora de acetato, inclusive foram embora esses dias. Mandei encinerar tudo.

ML - Isso já tinha sido filmado?

W - Uma parte chegou a ser filmada, mas não valia a pena, era tudo tremido, tudo com risco, graças a Deus que chegou a computação gráfica, porque eu pude passar a limpo todos os desenhos, escanear tudo, jogar no computador, pintar um por um, limpar tudo, ficou tudo limpinho, Deus esperou chegar a tecnologia pra eu terminar este filme. O filme ficou perfeito, tanto é que estreou até nos EUA, passou na TV americana, no canal STAR, e passou em mais de 70 países, então eu queria dar um plus na minha vida, que seria o quê? Tô lutando há anos pra sair do meu lugar, mas eu não desisti do caminho; eu encontrava aquele animador que vc falou e dizia: "vou fazer um longa-metragem", ele dizia: "cê tá louco, isso é coisa pra doido, só pra americano, eu dizia: "vou fazer um longa-metragem", só que eu fiquei 17 anos com ele em gestação. Na hora que saiu a lei estava tudo adiantado. Foi quando saiu a reabertura do cinema nacional, na época do filme da Carla Camurati.

Eu não faço série pra TV, eu odeio série pra TV, eu não vejo nenhuma satisfação, porque, ou vc tem satisfação no que vc faz, ou não faça. Eu odeio esses desenhos animados que tem hoje chapadinho com boca mexendo, eu nunca gostei de Hanna-Barbera, essas coisas, sempre achei uma porcaria, é atender ao mercado, a minha proposta é atender a minha alma, não ao mercado, entendeu? Vou tentar ganhar dinheiro fazendo as coisas que eu gosto, e não só por causa que o mercado precisa do seu trabaho pra fazer porcaria, por isso que eu acho que o desenho animado se desprestigiou completamente, hoje qualquer coisa é desenho animado.

$\mathrm{Na}$ hora de saber... o cavalo passou, cê tem que pegar e pular em cima dele, outros não fizeram isso. Arriscamos, cê joga... cê tem um patrimônio guardado, cê joga, gasta nessa máquina, Uma das coisas que me entusiasmou muito foi um dia, um material feito em computação gráfica feito nos EUA, material da ALIAS, a Alias era o software, o primeiro software que nós compramos, ALias Wavefront. A Wavefront era uma empresa, a Alias era outra, a TDI era outra, TDI tinha feito o Bicentenário da Revolução Francesa, eu pensei: "meu deus, como os caras fizeram isso?A gente tem que fazer essas coisas". Um dia o meu filho Rafael, tinha uns 12 anos na época, disse: "se vc comprar um computador desses pra mim eu faço." Aí, diante disso, né... Então eu tinha feito uns trabalhos pro México, falei: "vamos comprar um computador"; aí ele começou com 14 anos, fazer animação, um negócio que foi super emocionante, a primeira animação que ele fez foi pra NY, não foi pra Tucuruvi. Foi uma animação de um trem que vinha de um portal que abria, saía o trem com as crianças tudo, o Dr. Rabbit, que era um negócio da Colgate, uma boca se abria... ele modelou, tudo...

Então, é isso que eu digo, as mudanças que vc tem que fazer, hoje, todos esses equipamentos já foram pro lixo, mas o momento...se vc tiver o recurso, bem entendido, ou então vc empresta um dinheiro, se aquele momento é o de virar, vê tem que virar...

Falando da computação gráfica, vou dar um exemplo: nós tivemos um azar em parte, qual foi o azar? Que eu comecei a desistir da propaganda, eu vi que a propaganda não tinha mais nada pra oferecer, eu fiquei investindo no Grilo I (01:39:30), e no Grilo I a gente colocou muita coisa de computação gráfica, giro de câmera, o castelo girava, câmera descendo a escada, correndo, aquilo era feito em computação, o ponto de vista do personagem correndo, tudo em 3D. Foi um aprendizado pra fazer o segundo longa, o segundo longa foi todo em computação gráfica. Eu até briguei e disse: "nós vamos fazer o segundo longa em computação gráfica, sabe por quê? porque na hora em que a gente acabar esse filme em 2D, a imprensa vai criticar que nós estamos defasados, fora do tempo. Já tinha Toy Story, já tinha outros filmes em computação gráfica, e aquilo vem pra ficar, é epdemia, não volta.

Então, lançamos o segundo longa em janeiro de 2009; conclusão: nós estamos em 
janeiro de 2013 , até hoje eu não consegui dinheiro pra fazer outro filme. Nesse ínterim, o que vc faz? Vender frango na feira? Vc tem que fazer publicidade, ir atrás de produto, então vc fica naquela sanfona, corre pra cá, corre pra lá, e eu ainda tive um grave problema que eu não introduzi toda a computação gráfica que eu conhecia na publicidade, eu deixei pro longa. Porque eu tinha certeza de que com o longa I eu faria sucesso e ia ficar numa boa, e deu um dinheiro relativo e assustou todo mundo: "como um filme desses tem tanta criança assistindo?" $\mathrm{Na}$ época, eu fiz 280.000 pessoas. A primeira semana foi assim, eles calculam por final de semana, o primeiro final de semana; Só que vc não tem fôlego, vc não tem dinheiro pra manter o filme, cê não tem dinheiro pra investir na propaganda pra continuar o filme, cê morre por ali, deu aquela explosão, morre na praia; quando vem a rentabilidade, é baixa, se vc não fizer 2, 3, 4 milhões de pessoas, cê não ganha dinheiro, nós fizemos 260.000 , se fizesse 1000.000 de pessoas, tinha ganho. Hoje, qualquer pornochanchada tá fazendo 2, 3 milhões de pessoas, porque leva os atores da globo. Só que, eu consegui o meu espaço, aí conseguimos espaço facilmente pro segundo longa, foi bem, no segundo já fizemos quase 500.000 pessoas, mas tb não era esse o meu objetivo, eu queria fazer pelo menos 800.000 pessoas.

Mas vc conta com uma série de elementos agregados no seu histórico, que são:

-momento errado de entrar nos cinemas, cê dá de cara com um blockbuster americano, mós demos de cara com Madagascar e com Bolt. É um massacre. "Tem que mudar a data de lançamento", "Não!", a Fox: "Vamos entrar!". Entramos em 15 de janeiro, é férias; se entrassem em março, todos esses filmes já tinham passado. Nós ganhamos do Ratinho Despereaux, um filme francês, belga, e nós ganhamos de todos que vieram com a gente, de produtora independente que chama, nós ganhamos de todos. Fizemos mais público que todos. Só perdemos dos Bolt, Madagascar, essas coisas, que... 7 milhões de pessoas viram Madagascar...

ML - Pensou que o computador ajudaria ou traria mais problemas?

W - O computador só ajudaria, quebrou todos os paradigmas que vc tinha de "será que algum dia vai existir alguma coisa que vá substituir a animação feita a mão? Hoje, a animação feita na computação gráfica é tão boa, ou melhor do que a feita à mão. Por que? Só o fato de você poder fazer um ambiente se movimentar, você trabalhar com luz, sombra, coisas que eram impossíveis na mão, só isso já deu um elemento fantástico, não? Um dos pontos de partida pra essa revolução também foi o Roger Rabbit. Porque era animação feita à mão, com volume, só que o volume já era colocado no computador. e a gente fazia com aerógrafo. Roger Rabbit é um marco divisório, de grande sucesso, provavelmente existiam outros experimentos, né? Ali ele conseguia fazer sombra no personagem no chão, sombra do personagem projetado, fazia volume, luz e sombra do personagem, porque vc fazia toda animação normalmente, e vc fazia os layers também na mão, hoje vc faz direto no computador. fazia os layers na mão e aquele layer era expandido, então a sombra era preta e expandia pro marrom, então dava volume. O brilho, a luz, fazia o layer branco e expandia na cor do personagem, dava luz.

\section{ML - Que é isso, "expandir"?}

W - você faz um desenho, pega uma caneta, faz um desenho, e vc com a lente, no computador, vc expande isso aqui, ele fica suave, como um aerógrafo. Então, fica tudo aerografado, mas não era aerógrafo. Eu falava: "como é que esses caras conseguiram essas coisas?" Eletronicamente. Roger Rabbit foi o marco dessa coisa. Daí que veio a computação gráfica. Já tava fazendo os personagens em computação gráfica...

Da nova era, o filme mais horroroso que eu vi na nova era, eu já vi horrorosos vários, A Casa Monstro, da Dream Works. É um dos piores filmes que eu já vi na vida. Aquele filme que a criança não vê a hora que acaba, o cinema cheio... quando vc não vê a criança fazer "hum". O Ratinho detetive é horroroso, o Disney só se recuperou quando começou a "Pequena Sereia". Antes da Pequena Sereia, o Disney chutou o pau da barraca de dentro do caixão. "Sinbad, o Marujo", horroroso, o "Ratinho detetive" e "O Caldeirão Negro". A 
Disney teve altos e baixos, porque, a gente errar, as pessoas caçoam da gente, mas lá, eles erram à vontade e ninguém fala mal. Aqui, vc não pode errar. Eu encontrei o pessoal da Disney num congresso mundial da Unicef que teve em Praga, e eles falaram "com a Pequena Sereia, o Disney vai dar uma arrancada boa, vai melhorar. Tava o diretor da Disney.

ML - Qual o primeiro computador e o preço?

W - O Topas foi feito pra autocad, topas não era pra animação. Era animação bem precária, não fazia boneco, só objeto. Era pra arquitetura, essas coisas, mas o Topas depois morreu logo, tem um outro depois do Topas que é o... eu não lembro mais o nome... era 3D Studio. Seguido do Topas foi o 3D Studio, que já era bem melhorzinho, depois compramos o Sillicon.

\section{ML - O Sr. lembra o preço to Topas?}

W - Não lembro mais, mas era coisa de US\$30,000 a US\$35,000. Depois eu gastei com o Sillicon Graphics US\$ 80,000, mais placa, mais programa, eu gastei US\& 125,000. Uma vez eu estava na agência, comecei a trazer o pessoal da agência pra ver o Sillicon que a gente tinha comprado, era o único que tinha aqui, eles disseram: "mas o que adianta vcs comprarem o Sillicon, vocês não são... ah, brincadeiras de agência, que adianta comprar o Sillicon, vocês não são o Spielberg.

A Autodesk comprou o Maya, tudo, né?

ML - O software usado para desenhar objetos e ambientes, movimentos de câmera: qual era a saída, vocês imprimiam isso no papel, quadro-a-quadro?

W - Não, já imprimia em vídeo, tinha saída pra vídeo.

ML - E como vcs faziam a inserção do personagem naquele ambiente?

W - Aí, você tem que fazer a pós produção, tem que fazer a máscara, e na pós produção você aplicava. $O$ mesmo processo que fazer ao vivo, mesma coisa. $O$ animador tem que entender de tudo, onde vai entrar o personagem, por onde vai passar, onde vai sair, onde vai sentar, tudo direitinho, tem que checar tudo. VOcê se adaptava em função da precariedade, vc não podia sentar numa cadeira e fazer o giro, não vc tem que ficar em pé, ou andando, alguma coisa, depende do tipo de cena, eu tô dizendo um exemplo hipotético.

ML - Quando foi comprado o Sillicon, ele era mais usado para fazer vinhetas, assinaturas?

W - Você fazia objeto animado, lata de cerveja, garrafa, fazia tudo, packshot, fazia ambiente, fazia tudo, vc voava pela cidade, fazia tudo. Só não animava personagem ainda, fazia uma coisa ou outra, pequena.

ML - Quem da equipe foi designado para aprender a lidar com a máquina?

W - Tinha aí o Rafael Pires, que fazia a parte de computação gráfica, e depois o Rafael (Ribas) começou a aprender com ele. Depois outras pessoas começaram a entrar e está até hoje comigo Sérgio Spina, que faz computação gráfica e modelagem aqui.

ML -Quem modela anima também?

W - Nem sempre, mas o importante é que hoje em dia vai se especializando, então hoje em dia quem modela só modela. Quem faz cenário, só faz cenário, quem anima, só anima. Mas quando vc está numa firma pequena, vc tem que fazer tudo.

ML - O sr. Precisou de free-lancers? 
W - Sim, usamos, mas eu sempre fui inimigo de usar free-lancer, em qualquer circunstância. Porque não tem identidade com a firma, não vive o seu dia-a-dia. Mas a gente usa. né, hoje em dia tem que usar, porque o custo fixo ficou muito alto, então vc é obrigado a usar terceirização.

ML - Houve desconforto em algum setor da produtora quando chegou o computador?

W - Todos, né... é natural quando chega um interventor numa firma. O interventor vai achar defeito e vai botar alguém na rua, então fica todo mundo ouriçado. O computador é um interventor. Ele chega e vai mudar. Muda o comportamento, a atividade, muda o desenvolvimento da empresa, vai fazer a firma crescer ou ficar. Então acaba que ele incomoda, porque as pessoas começam a perceber que "eu não faço mais nada, vou cair fora". Isso foi acontecendo com o vídeo, com o computador...

ML - E quanto tempo levou para dar essa "enxugda" e que ficou um número mínimo de pessoas?

W - No decorrer de 2, 3, 4, 5 anos, foi acontecendo essa "enxugda". Não foi abrupto, assim: chegou o computador, vai todo mundo embora... uma das coisas que me fez mudar radicalmente aqui dentro foi o Collor, o confisco de dinheiro. Nessa época, eu tive que mudar, por quê? Porque acabou o dinheiro. Eu tinha 30 pessoas aqui dentro nessa época, mandei 15 embora. "não tem mais o que fazer, gente. Não tem mais trabalho, não tem mais nada". Foi aí que começou o negócio do vídeo, todo mundo fazer em vídeo, que era mais barato. Todo mundo cobrava um filme US $\$ 200,000,300,000$, eu via o orçamento do pessoal, não desenho animado, filme ao vivo, eu pensava, meu Deus, que grana, Us\$ 300,000; aí eu também comecei a cobrar o filme da Sharp US\$100,000, né, e aí, que aconteceu? Puf, acabou tudo, ficou todo mundo na rua da amargura, como é que eu vou pagar essa gente? Se não tem mais de onde tirar o dinheiro? Mandei 15 embora, na hora. Isso foi bem violento. A entrada do Collor foi um outro divisor de águas na propaganda. Enfraqueceu muita gente, muita gente morreu de enfarto, derrame. Muita gente perdeu tudo que tinha. Um amigo meu, um grande fotógrafo de publicidade, o Kato (?) japonês, tinha vendido a casa pra comprar um apartamento. Nesse ínterim, ficou sem casa e sem apartamento. Foi um confisco comunista, uma piração total, era judiar do povo, né?

ML - A mudança do analógico para o digital foi uma necessidade interna (reduzir custos, etc), ou externa (pedidos dos clietes, observação do que se passava no mercado externo)?

Ou as agências achavam que essa era uma proposta moderna?

W - Eu acho que as agências nunca estão atentas a isso, sinceramente. Até hoje, eu penso assim: as agências não estão tão preocupadas com o moderno, elas estão influenciadas pelos festivais. Vai todo mundo fuçar lá no Festival de Cannes. Chega lá, eles começam a ver coisa da Inglaterra, dos EUA, da Alemanha, da China, da Rússia, não sei da onde, né, que são os países que criam, que aqui não se cria nada, não, só confusão, né, mão-de-obra escrava... os que criam são Inglaterra, alguma coisa da França, Itália, Bélgica, talvez pouca coisa dos Estados Unidos, alguma coisa do Canadá, que também é fraquinho pra isso, são bons em software lá. Esse núcleo de países inteligentes, tem a Espanha, aí eles criam coisa... eles vão lá, e voltam cheios de idéias, não são deles. Aí você vê no ar, daqui a pouco, vc vê um filme "Produto Tal" cê vê esse filme, "pô, interessante esse filme", dia seguinte vc vê outro produto com o mesmo tipo de... filosofia, aí vc vê 3, 4 filmes no ar, mesma coisa, vc pode ver que é sempre depois que vem a temporada de "chupar", de copiar, eu acho que nunca estão atentos, quem mais está atento, o departamento criativo fica atento porque ele recebe muitos filmes, mas, o dono da agência não está nenhum pouco interessado com isso, um pouco [deles] vai muito mais dos festivais, quando eles vão receber a overdose de informação, eles voltam com a cabeça boa, fora também que viaja, 
né? e aí começa a pensar em mudar, mas nunca foram vanguardistas. Vanguardistas sempre foram as produtoras, os produtores sim, estão sempre se comunicando, comprando revista, vendo filme, fazendo pesquisa e vendo o que está acontecendo de todo lado. Hoje está um pouco diferente, mudou um pouco essa coisa, porque a internet tráz muita coisa, mas, sem dúvida nenhuma, uma coisa continua igual: "eu queria fazer um filme igual àquele lá" . Ninguém vem com uma idéia original falar assim: "pô, eu tenho uma idéia genial, queria fazer um trabalho assim, assim... não. Tudo vem assim: "vc lembra aquqele filme tal, que fizeram...? tem um negócio na internet agora, a gente queria fazer algo semelhante". Semelhante é chupar, é copiar, não é original, isso que eu acho ruim até hoje.

E quando eu fiz o filme da Sharp, eu fiz tudo original, vc não encontra cópia em lugar nenhum. Você pode encontrar lembranças, mas as lembranças, eu quando fiz o segundo filme da Sharp, aquele da ecologia, que eu ganhei o "Clio", quando vc ganha um prêmio internacional, irradia também influências, o filme saiu na revista Graphs, que era a revista mais importante de desenho, de grafismo, de cinema, animação, tudo, na revista Graphs saíram 2 páginas do meu trabalho, saiu na Graphs anual e na Graphs mensal. Antes, tinha saído na Graphs de animação o filme do Gato que eu fiz pra Eternit, na Graphs anual, e lá tem o filme de ecologia em que eu usei uma onça toda feita, pintada de caju. Aí, eu comecei a ver ilustrações que apareciam, vaca com manga, com fruta com um monte de coisa, do couro sai a correia, eu acho que muitas coisas você acaba influenciando as pessoas também. Eu vejo muita chupação, eu não sei se o pessoal não tem tempo de criar, ou a performance é diferente, mas há muito plágio. E vc tem que transformar o plágio numa coisa melhor, tentar fazer uma coisa diferente que não se perceba que é plágio. O vício continua até hoje, e sempre se abastecendo lá fora. Dificilmente sai uma coisa daqui pra fora, é sempre de fora pra dentro.

ML - Podemos dizer que usar computadores e se adaptar às novas linguagens foi uma iniciativa da produtora?

W - Foi uma iniciativa da produtora. Depois que você sabe que uma agência de publicidade em Londres tá usando só computador, os caras sabem, eles vão pros festivais e comentam, aí começam a usar também, hoje em dia, o cara não usa um fotógrafo pra fazer um Lay-out, não usa nada, ele pega uma revista, faz um lay-out...hoje as agências estão todas abastecidas com computador. Muitas vezes também o próprio cliente não aceita certas vanguardas, Eu acho que a propaganda cresceu muito nos anos 70 a 90, depois reduziu pro que era antes do 70 , voltou pro tradicional, só faz aquilo que dá segurança, só fica aquilo que é trivial mesmo, que o cliente vai gostar... eu mesmo tô fazendo um filme aí que poderia ser muito mais louco, mas o cliente quer ums coisas mais assim... não quer nada...é conservador quer tudo bonitinho, quer que, desde o favelado até o rico, que ele entenda. Então, você deixa de experimentar, deixa de avançar.

ML - Quando vocês passaram a usar o scanner?

W - Preciso verificar, depois vc escreve.

ML - Claro, e como que os orçamentos foram acompanhando a nova tecnologia?

W - Foram baixando cada vez mais, ao ponto de vc não ter necessidade de ter um estúdio desse tamanho. Essa sala é uma empresa, cabem 4 computadores, cabem 4 empresas aqui, cada indivíduo passa a fazer o trabalho em casa, faz o curso de computação lá, via muita coisa de tecnologia internacional, compra um software, não sei o que lá, vira uma empresa. Essa firma aqui é grande demais. Ou vc cresce muito, entope isso aqui de gente fazendo longa-metragem, essas coisas, porque, pra propaganda, isso aqui já é grande. Uma sala só num prédio é o suficiente pra você ter uma firma boa de computação gráfica.

ML - Então, um Sharp, que custava US\$100,000, nos dias de hoje, com a computação, etc, 
custaria quanto?

W - R $\$ 100.000,50 \%$ a menos. Menos do que isso não dá pra fazer. Eu estou fazendo um filme que é mais ou menos por aí o preço, pra copa do mundo, mas vou dizer uma coisa pra você: vc não ganha dinheiro. Você faz o filme defasado. Porque, se um elemento sozinho ficar fazendo o trabalho, porque eu planejo tudo, eu crio, planejo, jogo pra eles animarem, tem que fazer a ficha de direção, anotar tudo, quer dizer, tem um tempo. Cê tem aquela ficha de direção, que, chegou no fim vc não pode... se não vai cair no abismo, né. Chegou nnum limite ali, nada pode sair daquele registro, se não sai tudo fora do tempo, o cliente quer... a música, as vozes... e acontece que você faz todas essas coisas direitinho, você tem uma direção, um padrão, todas essas coisas têm que estar dentro de um contexto, né? Se eu cobrar o certo, seria cobrar $\mathrm{R} \$ 200.000$, com $\mathrm{R} \$ 200.000$, vc ganha dinheiro. Hoje, o que acontece, se vc paga um $X$ de salário, ainda vc dá uma gratificação pra pessoa, fica 3,4 meses fazendo, dissolve tudo, cê pega $R \$ 100.000, R \$ 25.000$ por mês, tem outras pessoas, vc não ganha nada. Não ganha dinheiro, mais. Antigamente vc fazia muitos filmes, vc tinha um padrão de $X$ de salários, pré-estabelecidos, ganhava um salário mínimo e meio pra pintar desenho animado, tinham poucos que ganhavam mais, mas não tinha muita fuga. não tinha muito pra onde ir. No momento que chegou a computação gráfica, pulverizou tudo. Todo mundo podia aprender computação. Animação não era todo mundo que aprendia ou que tinha talento.

Sem talento, vc não fazia animação; sem talento vc faz computação.

ML - O Sr. nota alguma diferença na mão de obra, o sr, que tem trabalhado prioritariamente com o Rafael, mas já passou outra pessoa aqui para trabalhar com computação gráfica?

W - No longa a gente teve gente muito boa aqui, no longa do Grilo II teve 30 pessoas.

ML - Existe diferença entre um animador que passou pelo desenho? O senhor acha que para se fazer uma boa computação gráfica o sujeito deveria ter noções de desenho animado 2D?

W - Deveria. Existe uma evolução incrível, hoje em dia tem muita gente boa trabalhando com computação gráfica. Mas, deveria aprender animação 2D, conhecer, ter conhecimento, mas ninguém quer. $O$ brasileiro pra aprender inglês, ele faz o básico, depois já vai pro avançado. Ninguém quer fazer o intermediário. O cara não quer dominar a técnica e depois fazer computação gráfica, ele já quer aprender computação gráfica e sair animando, e errando, fazendo Dollinho. Então, não sabe dominar, não sabe animar, não sabe sincronizar... então esse é o problema. Mas eu acho que uma direção é importante... Você ter uma direção de arte, direção de animação é importante. Só que ninguém está precisando mais desse daí, todo mundo sai fazendo. Você vai lá pra fora, continua o mesmo padrão: o cara tem que entrar na escola, aprender a fazer animação, aprender as artes, aprender as áreas que são pertinentes à produção, tem palestras, tem ensinamentos, o cara sai maduro, ele sai direto pro emprego. Aqui não: onde tem escolinha de computação e é tudo igual, e alguns que tem talento e gostam de fazer, acaba fazendo computação, faz uma escolinha de computação, aprende, mete as caras, e vai fazendo, e cria uma carência, que também acontecia com a gente em animação tradicional: vc não tem escola pra estudar animação; como é que eu estudei? Sozinho. Aprendi sozinho, com livro de animação, mas tráz pra você uma carência; falta base. Vc pula do básico pro avançado, cê não tem um intermediário. É conhecer a linguagem, fazer experiência, fazer pós graduação, um monte de coisa, aí vc vai pro mercado. Ninguém faz isso, tem uma pobreza, cê precisa de dinheiro, vc não pode morrer de fome, vc tem que comer.

Por isso que chega um certo momento da sua carreira que vc percebeu que faltou alguma coisa lá atrás. Esse é o problema maior. E acontece com todo mundo. As pessoas têm pressa. O latino é muito afobado. Já o alemão não é assim. 


\section{ML - Quanto tempo levava um filme da Sharp pra fazer?}

W - 3 meses. Era um minuto, né? E ninguém sabia se o começo era o fim ou se o fim era o começo. Eu invertia às vezes. QUe acontecia? No começo, a gente tinha muito filme pra fazer. Não tinha só o filme da Sharp pra fazer, tinha 5, 6 filmes pra fazer ao mesmo tempo. Você tinha filmes pra 5 meses pra frente pra fazer. Então o filme da Sharp era um terror, eu que fazia tudo. então vc começava a fazer a animação no início, fazia bem caprichadinho, bem elaborado, tal, a arte final, porque tinha tempo. E o filme ia avançando, de repente começa a faltar prazo, o cara fala "precisamos do filme, vai lançar uma televisão nova, como é que a gente vai fazer? " Aí que acontecia? Você invertia o filme: botava o mais bonitinho no fim do filme e o mais simplificado, mais desesperado no começo do filme.

E os caras adoravam, era uma festa: cada vez que eu terminava um filme da sharp era uma festa, um congresso, pra ver o que é que vinha de novo "que que você vai aprontar de novo?" porque eu não deixava ninguém ver, fazia mais ou menos uma idéia, mas não deixava ninguém ver, fazia como eu queria. Isso, no plano profissinal, por exemplo, era um absurdo. Uma empresa deixar na mão de um cara sozinho, vc vai lançar um negócio novo e não sabe o que vem. Era muito amadorismo, pensando bem, hoje em dia. Mas existia muita confiança em mim, que alguma coisa muito legal ia sair. $E$ eu achava até que era meio exagerado. Isso acontecia tudo num momento de alucinação constante, que tinha muito filme pra fazer. E eu cuidava de tudo.

ML - O Sr. Contagiava a equipe?

W - Eu que cuidava de toda gravação, eu que ia gravar a voz, dirigia a voz, dirigia a música, voltava correndo, tinha story-board pra fazer pro cliente, ficava até de madrugada fazendo o story-board, saía ia entregar pra agência, era uma verdadeira alucinação. EU falo pra vc, não sei como eu não morri. Porque mata.

ML - E este filme que vcs estão fazendo agora?

W - Esse a gente já está há três meses modelando, tem que ficar pronto até novembro. A modelagem é dificílima. A modelagem é mais difícil do que fazer animação tradicional. Em princípio, a complicação da computação gráfica, a modelagem de todos os produtos e personagens e objetos, isso é o complicado. Demora muito essa parte. Preparação de cenário, de personagem, detalhe. Tem que modelar tudo. Desenho animado, você fazia tudo num desenho só. Um radinho aqui, um objeto ali, isso você faz na hora. Faz o Lay-out, passa pro acetato, Em um dia você faz um cenário. Você não faz um cenário de computação gráfica num dia. Não existe isso. (02:20:47)

A vantagem da computação gráfica, é na hora de vc renderizar, de vc animar. Animação vc anima, vc não tem o cara pra intervalar, o cara pra fazer limpeza, o cara pra pintar, não tem nada, você faz tudo. Vc anima na massinha, tudo cinza, depois vc deixa tudo animadinho, direitinhho, dia seguinte, vc põe pra renderizar à noite, dia seguinte, vc vê a cena, ou um pedaço de cena; é lógico que vc vai processar o filme ainda, mas vc fez de uma noite pra outra, depois que vc animou tudo. Ao passo que a animação feita a mão, vc vai ver a animação pronta, vc vê: " tá tudo errado isso aí, refaz tudo". Volta a fazer do zero, tudo, esse é o problema. A computação gráfica veio facilitar a animação. E dá muito mais sabor ao filme, vc transforma um filme de animação num filme quase real. Agora, a modelagem é que é complicada. Tem que ter equipe grande, muita gente modelando.

W - qual sua opinião pessoal do que mudou na característica dos filmes - da Start, e depois de um modo geral? O que ganhou, o que perdeu?

ML - Pra gente foi substancial essa mudança da animação tradicional para a computação gráfica, deu um corpo mais profissional. Transformou a animação num produto mais respeitado. Hoje as grandes empresas de computação gráfica têm investimento altíssimo de 
bilhões de dólares. O Oscar só começøu a ser dado quando começaram os filmes em computação gráfica. Até então, Disney ganhou um Oscar de música de alguns filmes dele, nunca ganhou por algum longa-metragem dele; hoje um filme de CG participa num nicho separado, mas tem o oscar de computação gráfica, né? Não sei porque razão, Disney tem obras primas e que não receberam... é coisa de Mco, eu acho, isso; achar que a CG já é cinema, porque tem luz, tem sombra, tem perspectiva, tem volume, tem tudo. E antes, animação era coisa de criancinha ou de débil mental.

A CG despertou a vontades de pessoas em todo mundo de fazer CG, Hj vc vê, um cara pode fazer um filme na África, no Vietnã, antes era impossível; se a família tiver dinheiro, compra computador, o filho faz curso, faz longa-metragem, curta-metragem, faz um filme. Coisa que era impossível de fazer quando era feito a mão. Isso foi o grande benefício. Deu muito mais corpo e respeito para a animação. Transformou a animação mais "cinema". Consequentemente lucros, e verbas, investimento, isso foi fantástico. Cada vez que eu vejo um filme americano... porque filme americano é assim: ele pode não estar maravilhoso em conteúdo, mas cada vez mais a tecnologia é mais assustadora.

É um trabalho científico, CG é ciência, tudo é feito com software, com desenvolvimento científico; coisa que, animação, na época, vc nem ligava, vc faz a mão, é o desenhista que faz.

Troca de E-mails em 12/12/2013:

1-Data do primeiro seu filme comercial ----- Dezembro de 1959

2- Filmes iuguslavos que mais marcaram ----- Um dia um gato e outros trabalhos de Karel Zemman e Jiri Trinka

3- Filme da Nova Era - quem era o anunciante? ----- Sharp

4- Nome do músico que fez a trilha Steps para o filme "Som Colorido" --------- Stanley Black

5- Nome (ou o modelo) da máquina de Xerox ___ Rank Xerox

6- Com que solução se limpava o acetato? ---------Tricloroetileno

7- Nome da firma na Mooca que fazia telecinagem ------Não tenho idéia, por isso acho que não é relevante.

8- O ano em que usavam os Plotters para movimento de câmera -----Por volta dos anos 80 não sei precisar

9- Como é o nome do prêmio iternacional que vc ganhou com o $2^{\circ}$ filme da Sharp, o da Ecologia? ---------- Clio Award ---N.York

10- Quando passaram a usar o scanner para digitalizar e colorir? Por volta de 1995

11- O senhor morou no bairro de Santana? ------------ Sim morei lá por muitos anos em casas diferentes

12 - Em que período trabalhou na Lynx Filmes? -----------Comecei lá em 59 e fui até 62 dai pra frente, nunca mais fui empregado.

O nome da empresa que faltava, onde eu fazia as transferências de película para VT, era New Vision.

Quanto a Barata, de fato fizemos tudo ao contrario do método de limpeza de acetato usado naquela época, para conseguir transmitir a ideia de sujeira da casca da barata, passamos sobre o acetato, sebo de boi. Com isso ao pintar o desenho com tinta nanquim, a tinta só grudava em alguns lugares do desenho, e como a animação é uma sequencia de movimentos, a barata ao se movimentar, a pintura se movimentava e tremia, passando a ideia de sujeira.

O meu primeiro premio internacional na minha vida, ganhei fazendo em uma mesa de animação construída a partir de madeiras extraídas de uns caixotes.

Nem tinha disco de animação, quando tinha que girar pra acompanhar a curva do desenho, eu tinha que girar a mesa ou girava o corpo. A barata foi o primeiro personagem brasileiro premiado lá fora. 


\section{APÊNDICE C - Transcrição Entevista MESSIAS}

Entrevistado: Daniel Messias (DM)

Entrevistador: Maria Luiza Dias de Almeida Marques (ML)

Local: São Paulo- SP

Data: 21 de outubro de 2013

Duração da entrevista: 195 min

ML - Qual é a sua formação, o que te levou a trabalhar com animação, quais as suas inspirações artísticas?

DM - Minha formação é assim: eu sou autodidata, não fiz curso nenhum. Prá não dizer que não fiz, fiz um monte de cursos, esses cursos tipo museu de arte, que tinha, curso de desenho livre, etc, mas acho que o meu grande aprendizado foi com o pessoal da Gazeta, porque, muito cedo, eu era criança ainda, com 10, 12 anos, eu sei que até os 14 anos, eu frequentei a redação da Gazeta; a Gazeta tinha uma - o pessoal novo não vai se lembrar disso, claro - a Gazeta tinha um jornal, e nesse jornal havia 2 revistas, e tinha uma redação com ilustradores, e o pessoal que editava a Gazeta Juvenil, e, antes, Gazeta infantil, e tinham grandes ilustradores, Jayme Cortez, .... 02:12, eu realmente era uma criança, né, mas eu vivia lá, porque eu ia diariamente na redação com o meu pai, então, eu comecei a desenhar e criar vontade de desenhar realmente, criar o gosto pelo desenho, nessa época. Depois, com o fim da Gazeta, realmente, o meu grande mestre, meu grande professor, foi o meu pai, Messias de Melo, que foi ilustrador, foi chargista, do Jornal A Gazeta Esportiva; e eu frequentei esse mundo de editores, eles publicavam quadrinhos, eu fiz alguns quadrinhos também, prá editora Outubro, que era do Jayme Cortez. Eu praticava desenho natural, eles faziam sessões de desenho na casa desses ilustradores, na casa do Cortez, na casa do meu pai, mesmo, eu ia ao Zoológico, desenhava animais, eu fui treinando a anatomia humana e a anatomia animal com esse pessoal. Meu aprendizado foi aí, sabe?

Agora, eu tenho um curso de sociologia que não tem nada a ver com isso, eu fiz na USP, na época dos anos de chumbo, justamente de 1968 a 1972, mas eu fiz isso por diletantismo intelectual. Realmente não tem nada a ver com a minha formação artística. Resumindo um pouco é isso, né?

ML - O que te levou a trabalhar com animação?

DM - Eu gostava muito das charges esportivas que meu pai fazia na Gazeta esportiva. inclusive, na época de férias, eu substituía ele, eu ia lá e fazia a charge, eu tinha 12, 13 anos de idade, fazia charges, depois ele dava umas broncas, em casa, quando ele via no dia seguinte publicada, e corrigia, etc. Então, eu aprendi muito cedo a gostar de cartoon, né, que as charges, eram charges humorísticas.

E meu pai, por coincidência, adorava cinema. Ele tinha todos aqueles, até hoje eu guardo esses, ãh, câmeras de $16 \mathrm{~mm}$, câmeras antigas, e tal. Um dia, ele aparece com uma câmera quadro a quadro, chamava-se Paillard, era a marca da câmera suiça, que vc tinha a possibilidade de filmar quadro a quadro. E, começando a ler, eu tinha 16, 17 anos, a ler o prospecto, eu notei que aquilo podia fazer pequenas animações. E ele já vinha com uma pecinha que era um titulador, que você pegava a câmera de um lado e tinha um dispositivo que vc ia colocando os cartõezinhos, ia substituindo e você criava a animação. E eu fiz um teste - foi assim que eu aprendia a animar - eu fiz um teste, mandei revelar na fotóptica, e a coisa se mexia, sabe? Aí foi um encantamento, né?

Eu já adorava, por exemplo Tom e Jerry, eu ia nas sessões do cine Metro e adorava, eu sempre gostei muito de cartoon, quer dizer, animação de cartoon. E eu comecei assim, sabe?

Eu conheci na época um colega de escola, chamado Eli Barbosa, depois ele viria a fazer quadrinhos, e a gente, junto, nós montamos um estúdio, uma sala, lá em Santana, na casa dos meus pais, que era uma casa grande, e a gente começou a pesquisar, pesquisar 
animação, comprava filme, e ficava desenhando, quer dizer, uma coisa doida, né, porque não havia escola de animação, não havia um mercado ainda. E a coisa foi se desenvolvendo assim, esse foi, vamos dizer, o primórdio. Até que nós fizemos um primeiro filme, "Três Leões". Três Leões era uma loja de departamentos grande, eles tinham uma conta na Standard. Hoje é Standard, Ogilvy \& Mather, na época, era só Standard Propaganda, e eu não sei como um amigo do meu pai falou: "olha, vocês vão lá que eles têm um filme prá vcs fazerem...", e nós fomos e realmente tinha esse filme da Três Leões. Um filme de $30 \mathrm{seg}$, que eu animei junto com o Eli, foi nosso primeiro filme, né... sonoro, em preto-e-branco ainda. (07:07)

ML - suas influências artísticas seriam mais os cartoons do que o cinema?

DM - Na verdade, eu fiz uma fusão desses interesses, porque eu adorava também, adorava animação, mas, por incrível que pareça, eu gostava muito mais do cinema de deboche, do cartoon, aquela coisa mais hard core, desenhos, por exemplo da Metro, do Tom \& Jerry, do que dos desenhos da Disney, que eu já achava muito infantis, claro, eu não era mais criança, mas eu perdi o interesse pela Disney cedo, sabe? Fiquei encantado pela charge. Porque o ambiente que eu frequentava era um ambiente assim, de pessoas como chargistas, de deboche, do politicamente incorreto, a turma brincava muito... e eu adorava viver nesse universo. Isso teve muita influência sobre mim. Quando eu vi os primeiros filmes da Metro, eu fiquei sonhando, babando em fazer alguma coisa daquele tipo, tanto assim que o primeiro filme, dOs Três Leões, tem um leão que eu animei mais com cara de gato, do Tom, do que do próprio Leão... Eu estava muito influenciado pela estética da Hanna Barbera, eles eram da Metro, na época, eles faziam grandes filmes, grandes animações. (O filme Três Leões é de 1958) - (09:18)

Foi na época de substituição da propaganda americana pela propaganda nacional. Porque as primeiras propagandas eram todas americanas, e se importava propaganda aqui. QUer dizer, quem tinha dinheiro prá bancar, como a Bardahl, por exemplo, trazia os filmes já prontos dos EUA. E quando ficou inviável, e o anunciante brasileiro começou a ter dinheiro prá investir em propaganda de TV, então começou a se criar um mercado interno aqui, né

ML - Quando o Sr. abriu o estúdio? Com quais equipamentos? Quem era a equipe? Primeiros filmes e os clientes?

DM - Eu passei pela Lynx Filmes, que foi a grande produtora, eu acho que essa foi a grande escola de animação no Brasil, foi a Lynx Filmes, e estranhamente ignorada, sabe. A Lynx Filmes ainda merece um exame profundo dessa experiência, não só em animação, de cinema ao vivo até de laboratório; realmente foi uma coisa paradigmática, a Linx Filmes foi fantástica, eu trabalhei 7 anos lá. Foi toda a minha formação profissional, meu aprendizado de animação, e não só de animação, de direção, porque eu fazia animação, muitas vezes eu fiz arte final dos meus filmes, e eu fazia os cenários, também, quer dizer, isso me deu uma grande perspectiva do trabalho, assim, holisticamente considerado, foi na Lynx Filmes. Então, na Lynx, eu trabalhei 7 anos, de 1960 a 1967, e eu acho que foi um perído muito bom, esse que eu te falei. (dan mess_3 - 00:11). Agora, em 1967, a Lynx começou a exaurir, a proposta da Lynx realmente era outra, ela virou muito mercantil, então eles estavam fazendo filmes que não me interessavam, filmes de varejo, eu comecei a sentir que as perspectivas eram ruins prá mim, de futuro, eu era um jovem ainda, dominando animação, eu tava realmente tinindo como animador, e eu queria fazer alguma coisa diferente, e eu percebi que não havia condições na Linx Filmes.

Então, eu saí para uma carreira solo. Parti para o trabalho de freelancer, e fiquei nisso, trabalhando como freelancer, até 1975, mais ou menos, quer dizer, quando eu trabalhava prás produtoras, que tinham, que a maioria das produtoras era de filme ao vivo, não tinha um departamento de animação, então, eu comecei a montar um pequeno departamento, no meu estudiozinho, que era uma salinha lá em Santana. Então, eu tinha um freelancer lá, que fazia o trabalho em acetato, filmava, câmera, né, eu tinha tinha câmera 
$35 \mathrm{~mm}$, já. Depois eu peguei uma mocinha que ajudava a pintar os acetatos também. Ou seja, a minha equipe era de 3 pessoas.

Isso até 1975. Aí, eu comecei a trabalhar prá grandes agências, de repente começaram a aparecer trabalhos prá DPZ, prá McCan, prá Thompson, e eu não tinha estrutura mais, e as produtoras de "ao vivo" não tinham mais interesse em trabalhar com freelancer. Então, só me restava a alternativa de montar uma produtora, uma empresa de animação, quer dizer, trabalhar como diretor e ter meu próprio estúdio. $\mathrm{Em} 75$, eu montei esse estúdio. Na ocasião, eu tinha realmente uma arte-finalista, eu era o animador de cartoon, eu tinha um assistente, o Borghi, que fazia arte-final, fazia efeitos também, ele gostava muito de trabalhar com back-light, sabe, aqueles efeitos típicos da câmera; eu gostava sempre mais do desenho. E tinha uma mocinha fixa fazendo arte-final. Naquela época a gente fazia a arte final em acetato. Então, eu não tinha xerox, ainda. Nós estamos falando de 75, o trabalho era feito na mão, o que a gente chamava de filete, que era o contorno de um lado do acetato, então, se virava e pintava o acetato atrás. Quer dizer, essa era a minha equipe básica, isso em 1975.

Quando eu montei a produtora, então eu senti que eu precisava me estruturar mais, ter mais gente, ter um lugar melhor, ter mais equipamento, essas coisas todas. $E$ eu comprei essa casa aqui, que estava a venda, rua Tupi, Tive que fazer uma reforma imensa. Bom, aí eu já me estruturei, eu já consegui o emprego de um animador, animador fixo, que ficava comigo full time, eu tinha duas moças fazendo arte-final, comprei uma xerox, a equipe começou a se desenvolver, nessa base, quer dizer, foi toda uma evolução até chegar à época do computador... e foi também o boom do comercial de TV. A televisão na década de 1970 explodiu realmente. Os estúdios de animação que faziam trabalhos, digamos, de qualidade, que o mercado exigia, eram muito poucos. Eu me recordo que na época tinha o Walbercy da Start Filmes, o Gui Lebrun, que depois se transformou em Briquet, tinha o Joaquim 3 Rios, e tinha a Lynx Filmes. A Lynx continuou ainda, mas um pouco decadente. Quer dizer, esse era basicamente o mercado inteiro, não vou dizer brasileiro, porque o mercado estava todo em São Paulo praticamente, o mercado de $1^{\text {a }}$ qualidade, top; eu fiz muitos filmes nessa época, a gente fez grandes séries. A equipe foi aumentando, isso era 78 .. 80, eu já tinha uma equipe grande, eu cheguei a ter mais ou menos na casa aqui, eu acho que umas 17 pessoas, prá mim, isso era muito grande, eu não queria... eu trabalhei sempre tentando conter a expansão, virar assim uma mega empresa, eu não queria, eu nunca quis ter um estúdio grande, se eu tive esse número, (foi porque) de repente eu estava fazendo três filmes por mês, que, em animação tradicional é uma coisa estúpida. E eu precisava então de muitas artefinalistas, muitos intervaladores, mas eu não queria ampliar isso ao nível que virasse uma enterprise. Eu me lembro que um amigo meu, o Jaime Cortêz, esteve aqui né, e disse: "Não adianta, Daniel, você vai ser sempre uma boutique"; eu gostei dessa qualificação dele. Eu acho que é esse realmente o espírito da coisa. Eu preferi sempre fazer comercial, isso parece paradoxo, do que fazer longa-metragem por exemplo, sabe, ou mesmo curta-metragem de série, sabe, que hoje está-se fazendo bastante. Porque essas coisas você tem um compromisso com a indústria, com o sistema de produção em série, uma coisa que não me atrai muito. Eu prefiro entrar num projeto - eu sempre procurei fazer isso - e você sair rápido dele, você executar um projeto e mudar a perspectiva no próximo projeto; você não enjoa com ele, não fica saturado. estressado demais. Num longametragem você embarca e fica dois anos fazendo a mesma coisa... a mesma coisa no curta-metragem de série, sabe, eu recusei um agora, que o meu amigo Nicokai está fazendo, por causa disso, eram dois anos e meio de produção de Mônica e Cebolinha, eu falei: "não, eu não vou aguentar", e propus para um amigo meu, o Tureta da Cartoon Network, eu prefiro abrir mão. E abri mão de um projeto, que poderia ser interessante se fossem outros personagens.

ML - Qual o primeiro filme com a empresa nova, de $75 ?$

DM - Eu me lembro, eu saí de Santana - o meu estúdio ficava na casa dos meius pais, meus pais tinham um casarão de $900 \mathrm{~m} 2$. Era uma casa imensa e, no fundo, eu construí uma 
edícula muito confortável, parecia uma fazenda, uma hacienda, sabe, era o meu estúdio láeu já estava reformando essa casa, porque o projeto era grande, projeto de um arquiteto, eu comecei a fazer esse filme lá e vim terminar aqui no estúdio. Era um filme do Snoopy, 30 seg, prá Yopa. Era um ano que tinha eleições, era engraçado, foi em 1978. O filme chama Yopa- Eleções; então, tem uma... como se fosse um palanque assim, uma mesa, e está o Snoopy, está o Charlie Brown e a Lucy, eles estão falando "Yopa, Yopa, Yopa"; eles estão fazendo um discurso e o Snoopy te uma plaquinha assim, que ele não pode falar, ele levanta a plaquinha, é muito divertido. Eu comecei esse filme lá e vim terminar aqui.

Esse foi o primeiro filme que eu fiz aqui. E eu fiz no processo tradicional, em 78 não se falava ainda em computador. Se usava o acetato e se pintava manualmente. Você usava edição cinematográfica, moviola - eu tinha uma moviola aqui - e filmava aqui também. Eu tinha câmera e todos os recursos aqui. Esse foi o primeiríssimo filme aqui. Depois vieram uma série de Snoopys; o produtor americano esteve aqui no estúdio, ele chemava-se Bill Melendez, faleceu há pouco tempo. Ele fez todos os longa-metragens e curtas com o Snoopy. Ele esteve aqui visitando a gente, gostou muito do desenho. Eu fiquei como exclusivo do Snoopy até o fim. O Snoopy saiu de moda, quer dizer, hoje ele é old fashion, é desses personagens que entram e saem de moda, então, não se faz mais Snoopy. Eu fiz todos os comerciais dele no Brasil.

ML - Como eram feitos os orçamentos? Quem fazia os cálculos de orçamentos dos filmes? Como era a distribuição da verba? Quanto era destinado à equipe e quanto era para a manutenção do estúdio? Quanto era para material? Como o sr. pensava ao apresentar um orçamento?

DM - Se eu te falar como funcionaram sempre as coisas aqui, você vai dar risada, porque como é possível, ãh, uma produtora hoje não sobreviveria nesse esquema que eu assumi, que eu adotei. Mas, justamente por um paradoxo, o estúdio só sobreviveu, e eu acho que o meu estúdio foi o mais longevo de todos, porque, se você considerar que, olha, eu oficialmente comecei em 1975, e terminei este ano, praticamente como estúdio, como grupo de trabalho, quer dizer, eu não tenho mais equipe. Uma equipe assim como eu tinha antes, eu não tenho mais. quer dizer, ter 20 pessoas, funcionários pela CLT, etc, isso se tornou inviável, impraticável. Então, eu sobrevivi muito tempo; como é que eu consegui sobreviver? $\mathrm{Eu}$ acho que foi uma coisa meio que administrar domesticamente uma casa, entendeu? como é que se administra domesticamente uma casa? Pelo bom senso, né? Uma pessoa que está dirigindo uma casa, seja homem ou mulher, na economia de uma casa, se gastar mais do que recebe, quer dizer, se a despesa for maior que a receita, com certeza está liquidada. E eu administrei a coisa assim; não havia uma pessoa, eu nunca tive sócio. Nunca quis ter sócio, acho que mais pelo meu temperamento, eu tenho certeza de que eu trombaria com ele, não foi falta de oportunidade. Eu tive muitas propostas. Eu sempre fugi disso. Eu me vi obrigado a eu mesmo fazer o orçamento; eu tinha uma pessoa - que está comigo até hoje, a Ana - e uma outra pessoa, o Borghi, que virou fazendeiro hoje, ele ganhou mais dinheiro do que eu fazendo animação comigo, e a gente fazia, em dois, o orçamento. Quer dizer, eu era guiado pelo bom senso intuitivamente.

Eu não fazia cálculos porque ficava inviável, eu não queria perder o meu tempo, perdendo um ou dois dias, até mais, fazendo cálculos de custos, de insumos e mão de obra e de material, então, eu orçava assim: "eu vou ter algum lucro se eu orçar X." Porque a minha experiência foi a seguinte: se eu orçasse US\$1000,00 por segundo, intuitivo, sempre que eu pudesse manter este valor, eu tinha alguma margem mínima de lucro. Mas esta margem mínima de lucro é como em qualquer micro-empresa, entendeu, em 15 dias ela estaria já diluída com as despesas. Porque a mão de obra é muito cara, sempre foi muito cara em animação, custo, na época, de filme, depois, de software, etc, essas coisas, eh, realmente, você falar em "lucro" em animação, é uma tolice, sabe? não existe. Um estúdio de animação é uma pequena empresa, é uma micro-empresa, ela não tem lucro. Se ela tiver lucro, alguma coisa está errada, ela não está investindo em equipamento, nem em mão de 
obra. A minha perspectiva, a minha esperança sempre foi investir em mão-de- obra, principalmente em mão-de-obra.

O que eu mais sinto falta, dessa natureza do sistema de produção, é justamente essa congregação de profissionais. Porque, com isso, todos aprendem. Eu sempre soube escolher muito bem os profissionais, quando você junta uma plêiade de grandes profissionais, que tenham sensibilidade, que tenham, digamos, apuro, tenham alguma cultura artística, você aprende com eles também, é uma troca geral. Isso, você só consegue num sistema de produção de grupo de animação em estúdio. $E$ hoje, a tendência é justamente isolar cada profissional, frente a um monitor, um tablet, às vezes trabalhando em home office. Isto é, nem agrupar o pessoal num estúdio, numa sede, isto está acabando. por uma série de razões. Uma delas é o conforto: é muito melhor você trabalhar em casa do que se deslocar até a firma diariamente. Outra, o trabalho em casa possibilita ao jovem trabalhar com $\mathrm{N}$ fornecedores, ao invés de vender o serviço para um exclusivo, enfim, a tendência é cada vez isolar mais isso. $\mathrm{E}$ isso é ruim porque cria individualidades, cria gênios no computador, mas também cria pessoas que têm uma visão bitolada, uma visão estreita, e não compartimentada, quer dizer, ao mesmo tempo que a formação de novos profissionais fica muito mais difícil assim, desse jeito. Por isso há hoje uma tendência ao êxodo, o pessoal buscar aprendizado lá fora. E lá fora, eles vão encontrar exatamente essa associação, nas escolas. Qualquer escola americana, canadense, francesa - lá tem boas escolas de animação - é o trabalho de grupo que vale. Os projetos são todos feitos por grupos de trabalho. Eu sinto que é muito difícil hoje vc reunir isso, a experiência que eu tenho conhecido aqui, de produtoras, são pessoas muito mais voltadas ao trabalho exclusivo do computador. Pode ser que eu esteja enganado também, mas esta é a minha visão. (O orçamento) dependia de uma série de variáveis. A gente não tinha um expert - ninguém tinha - dentro da produtora, porque eram estúdios muito pequenos, eram estúdios do profissional.

Você quer ver um fenômeno curioso: as produtoras, naquele tempo, têm o nome do seu titular, uma tradição que já vem da Disney, então, era Briquet Filmes, era Guy Lebrun Filmes, era Joaquim 3 Rios Produção, era DM - Messias. Sabe por quê? Cada profissional era conhecido, o Eli Barbosa, você vê, na reallidade, o estúdio era o profissional titular. Se você era um profissional, digamos assim, creditado, ou considerado pelas agências como bom profissional, você tinha um acesso fácil às agências, ou, facilitado pelo menos; o Walbercy quebrou um pouquinho isso e colocou o nome Start. Todo mundo colocava o nome mesmo, mas depois isto começou a pesar. Mas aí, prá mim, era muito tarde tirar isso e mudar prá Stop Motion filmes, ou sei lá, Frame filmes, ou qualquer coisa assim, porque não iam mais associar o estúdio anterior, e eu tinha conseguido uma imagem boa.

Então, voltando à história, todos faziam seu próprio orçamento. Era muito de chutômetro, então, era muito intuitivo o processo, quer dizer...

ML - E a distribuição? Vamos dizer, um terço ou um quarto para equipe, um terço para capital de giro...

DM - Não, não havia esse cálculo. Não havia porque ninguém conseguia ter reservas. Quer dizer, ninguém conseguia poupar prá ter uma reserva, todo dinheiro que entrava saía, e saía, eu tô falando em talvez duas décadas, essa foi a tradição, porque o dinheiro tinha que ser rapidamente reinvestido em mão de obra, e a mão de obra ficava cada vez mais cara. Cada vez o processo foi ficando mais sofisticado. No começo, eu fazia animação sozinho. Fazia animação, intervalação, e eu não tinha cleaner, por quê? porque o meu assistente, o Borghi, era um azougue, ele era espetacular, ele pegava o acetato, colocava sobre o papel, com nankim, pincel seco, ele cleanava direto em cima do acetato. O meu desenho, que era muito rafeado, eu nunca trabalhei "clean", o meu desenho sempre foi rafeado, ele colocava na prancheta, colocava o acetato em cima, com pincel seco e com nankim, ele dava o traço, aquele traço meio... que você vê no frango, na década de 70 , e depois, ele mesmo pintava, quer dizer, eu não tinha uma equipe muito sofisticada nos primórdios, então, de repente, o trabalho, o estilo ficou mais disneyniano, a tendência da animação; até hoje continua, em 2D, 
disneyniana, é um trabalho muito sofisticado, uma linha muito pura, muito bem tratada, então você tem que ter, primeiro, um bom animador, segundo, um bom assistente, e todos eles trabalham muito limpo a linha, e tudo cleanado, e mesmo quando vc escaneia este material, e pinta, todo ele fica muito asséptico às vezes, o desenho é todo muito limpo. Então, isso passa por muitas mãos, ou seja, o processo de produção - e eu me refiro ainda ao processo de 2D tradicional - mesmo na fase computadorizada de edição e de pintura, etc, ele foi ficando muito sofisticado, muito caro. E, cada vez mais esse dinheiro, se vc quisesse se manter no mercado, você tinha que investir em mão de obra.

Mesmo quando surgiu o computador, a mão de obra ficou mais cara ainda. Parte da equipe, que era razoavelmente barata, que era a equipe que fazia a pintura em acetato, que eram quase todas moças,esse contingente foi substituído por gente que já tinha uma formação universitária ou pré-universitária, já de informática, já tinha um nível superior, então, um custo também mais alto. Então, sempre foi uma historia de pequena empresa tentando sobreviver investindo em mão de obra nova. Não sobrava recurso prá se ter uma reserva, você ter capital.

ML - É curioso como os filmes não denunciam isto...

DM - Aí é que está o grande mistério; eu já me perguntei isso, e essa pergunta é feita também por gente da área. "Pô, Daniel, como é que a gente, apesar de todas as dificuldades, fazia filmes tão bons?" Eu acho que são os milagres da vontade de fazer um trabalho interessante, do amor que se tinha pela animação, aquele tesão, aquela coisa fantástica que precedeu a racionalidade do sistema, digamos assim, mais pré industrial de produção. Então, naquela época também, a feitura de um orçamento era muito baseado naquilo que o Joaquim definiu bem, do chutômetro. Quer dizer, eu calculava, a minha base era a seguinte: US\$1000,00 por segundo, eu acho que os outros também adotavam uma coisa parecida, a gente sabia por experiência que dava uma margenzinha razoável de lucro...

ML - Mas um filme de $30 \mathrm{seg}$, US\$30000,00, não é muito pouco?

DM - Hoje é muito pouco. porque o dólar hoje está quase que equiparado. Mas na época era um bom dinheiro. O dólar já esteve bem mais alto. Às vezes era até muito difícil a gente orçar isso; eu não digo que sempre eu conseguisse orçar US\$1000,00 por segundo. Tinha vezes que... isso, sabe, não tem como dizer, qual é o preço fixo de um filme de animação. Se alguém disser isso, está faltando com a verdade, porque, na realidade, a agência impõe. O mercado, antes da agência, o mercado impõe esse preço. O preço é uma imposição do mercado, a famosa lei da oferta e da procura. Segundo: a relação que você tem com a agência. Então, se você tem uma relação fixa com a agência, eu tive esse tipo de relação muito com DPZ, com McCann, com Pro-M, a Thompson eu trabalhei, mas não muito fiz alguns filmes, a Kellog's, sabe, fiz algumas coisas prá THompson. Com a DPZ, Standard, ALmap, essas são as agências que eu mais trabalhei. Eram agências que mantinham estrutura funcionando. Às vezes me davam dois filmes por mês, o que é uma produção grande para um estúdio pequeno.

Bom, às vezes a agência tinha um grande orçamento. E sempre vazava isso, sabe, um orçamento bom; aí eu orçava dentro desses parâmetros, às vezes podia ser mais do que US\$ 1000,00/seg, mas às vezes não tinham. E a menina chegava e "não temos". E não vamos fazer o filme? E valia a pena se fazer o filme. O meu critério era o seguinte: primeiro, é se há um mínimo de lucratividade no projeto, eu não quero ter prejuízo. E quando eu falo em lucro, eu não estou falando $100 \%$ de lucro. Eu quero ter uma margem, ãh, assim funciona o sistema, se não tiver nenhum de lucro, então você não está fazendo... você está arriscado a fechar. Agora, o segundo critério é o seguinte: está se pagando, não tem lucro nenhum, dá prá pagar a equipe, mas é um projeto que vale a pena fazer. Eu fiz montes desse tipo de projeto prá Cartoon Network. Porque emissora de TV, mesmo a TV fechada, eles nunca têm dinheiro, não têm verba. A Cartoon Network essa fama do Cartoon, etc, e tal, mas eles não têm dinheiro. quer dizer, eles chamam você prá fazer uma vinheta de 
$\mathrm{R} \$ 20.000,00$, quer dizer, 10 seg de animação. E eu fiz algumas antológicas, a vinheta do "bundifola" dançando, imitando a Globeleza, do carnaval, etc... eles não tinham dinheiro prá fazer. Eu me lembro que eles tinham uma verba prá fazer 5 seg de animação. E o filme tinha 15 seg. A Manuela lá me falou: "olha, eu não vou fazer este filme porque não tem verba." Eu falei: "por que não tem verba? Quanto você tem?" "Eu tenho X." Eu não me recordo bem, era uma mixaria. Eu falei: "Vamos fazer este filme, vamos fazer." Você vê, é um universo meio pantanoso, é uma coisa que você tem que administrar e ser flexível, não adianta... você não tem preços fixos, ninguém vai te dar um preço fixo, e ninguém tá fugindo da resposta não, sabe? Se alguém quer ganhar dinheiro, eu aconselharia realmente um outro negócio, porque animação é um processo lento, demorado, e no final não é tão lucrativo. Como encher linguiça: eu tenho um amigo que o negócio dele era procurar fibras de linguiça e ele ficou arqui-milhonário! Mas animação é prá quem gosta realmente. Quem gosta, não mede essas coisas. Ele faz o projeto: tem prejuízo em um, compensa no outro... e vai tocando a vida. Eu sou muito metódico.

Se você entra inconsequentemente num projeto, você está colocando em risco também pessoas que estão no seu time, que estão ajudando você. E essas pessoas têm todo o direito de receber quando termina. Eu nunca entrei num projeto que tivesse que sair pela tangente, ou fugir de um credor, não, sempre sempre paguei todos os compromissos, toda minha equipe, quer dizer; eu gostaria que fosse muito simples fazer um orçamento, mas não é. $E$ ainda entram alguns fatores muito típicos da nossa cultura: você calcula tudo direitnho, e quando apresenta prá agência eles dizem "você sabe que tem $10 \%$ de BV", que até hoje eu não sei o que é BV. É aquilo que você paga prá trabalhar. Bom, eu não sabia que tinha isso. Eu fiz um orçamento, calculando um valor que jà tinha às vezes sido acertado aprioristicamente, por telefone até "vai custar X", "OK, me apresenta isso no papel". Eu coloco no papel e me aparece o BV. Quer dizer, então, eu vou reorçar o trabalho. Isso é muito é muito da nossa cultura, infelizmente, isso acontece em 10 entre 10 orçamentos que me pediam.

ML - Quem definia o lay-out artístico do s filmes? Traço, paleta de cores? decupagem, Story-board?

DM - Sempre fui eu, em todos os filmes, em 10 entre 10, este era o meu trabalho.

A parte de pré-produção, scene planning, planejamento de cena, sempre foi o trabalho que eu quis fazer, e a parte de direção visual também, sabe? A cor, o estilo do desenho, os caminhos a serem tomados, as opções de software, vai te toon-boon, ou vai de animação tradicional, ou em 3D, eu só não faço stop-motion: só fizemos um filme de stop-motion, que foi o free-jazz festival, feito acho que há 30 anos. Mas geralmente a escolha é sempre minha, sabe, antigamente eu fazia tudo isso e animava também. Aí eu falei, não dá mais, fica impossível fica inviável também fazer todo este trabalho. Aí, eu comecei a delegar muito a animação. Supervisionando o trabalho, claro ou às vezes animando uma ceninha dentro do filme.

O trabalho de animação, é um trabalho exclusivo. Um trabalho de concentração, e o profissional tem que ficar lá full time, só fazendo aquilo. Ou você faz isso, ou você faz coordenação do projeto. Porque tem muita coisa na direção, no planejamento que você tem que fazer que te tomam tempo integral, já. $E$ eu prefiro fazer isso porque eu mantenho o controle overall do filme, do que fazer a animação e entregar isso para um outro, um terceiro, o que não tem nenhum sentido. o cara fazer um story-board, e eu fazer a animação. Então, eu passei a sempre fazer essa parte de direção, story-board, planejamento de cena e direção visual também. Isso tudo implica em decisões. Quando você pega um filme, a agência, quase sempre, não sabe o que fazer. "Olha, nós temos um roteiro assim, o que você sugere?"

Eu me lembro um filme de cut-out prá Cartoon que a gente fez, foi um negócio bem sucedido. Eu tinha visto um filme, "El Kabong", era um filme americano, uma sátira do mexicano, que era muito legal aquilo, então eu disse, "vamos por essa linha?", "vamos". Quer dizer, essas idéias nascem assim, essas escolhas, implicam você apresentar 
propostas criativas prá agência, eu não vejo outra pessoa fazer isso do que eu. Quem tem que tomar a decisão se o filme vai ser feito em Toon-Boom ou se vai ser feito em animação tradicional, isso é uma escolha difícil prá mim, mas por uma questão de prazo, por paradoxo que pareça, eu preferi a animação tradicional, desse filme de 10 minutos, a gente tinha 0 prazo ridículo de 3 meses, nem isso. $E$ acabamos fazendo, deu certo, eu tive mais uns 3 meses prá fazer a pré-produção. Mas prá fazer em Flash ou em Toon-Boom, eu precisaria de 6 meses, prá criar todos os features vetorizados, de todos os personagens, eram montes de personagens, e todos story-boards prontos, quer dizer, prá fazer os features, criar o banco de dados, eu precisaria ter todos os story-boards prontos.

Você não acredita como nós fizemos esse filme. A gente animando uma sequência do filme, a sequência $n^{\circ} 5$, que tinham 6 sequências, e ele não tinha entregue o story-board, o rough do story-board da sequência número 6 ainda. E a gente animando o filme já. Quer dizer, coisas desse tipo acontecendo, quer dizer. Se fosse fazer isso em Toon-Boom, que hoje se faz as séries tudo em animação vetorizada, eu ia precisar de pelo menos dois anos prá fazer o filme. Eu ia precisar de Story-Board pronto, ia ter que lutar com "os três amigos", o Angeli, o Glauco e o Laerte, e o Adão, eu ia precisar que eles me entregassem todo o story-board, porque em cima do story-board, nós adaptamos todo ele para a linguagem da continuidade da animação, porque algumas coisas não tinham a linguagem, não tinham as passagens, as transições, porque a mídia era outra a deles, os quadrinhos.

\section{ML - Por que um prazo tão fechado?}

DM - O prazo foi imposto por mim mesmo, porque, nesse sentido, eu tive duas pessoas fazendo cálculo de custos, então, eu fiz uma conta simples: eu tenho X por mês. Na época dava parece que o quê? 100 mil, 130 mil por mês. Quer dizer, se eu gastar 8 meses prá fazer esse filme, eu vou ter que tirar dinheiro do bolso prá pagar. Tá na cara. Ou então, eles vão ter que aumentar a verba do filme. Então, não é nenhuma coisa, nem outra. Quer dizer, não dava, eu tinha que fazer o filme em 6 meses. Quando dispararam, o dinheiro foi creditado na conta, eu falei: "agora temos 3 meses prá fazer o filme", porque tinham passado 3. Lá a coisa prá ANCINE, voltava, documento, etc, e tal, era um processo burocrático demais, enquanto isso, o Laerte ia jogando os story-boards e eu ia fazendo junto com outro animador. Eu dividi em 2. Eu fiz 3 sequências completas, planejamento de cena, e esse animador fez mais 3 sequências. A gente ia trabalhando bravo, eu fiquei assim até praticamente, nossa, uma semana antes de terminar o prazo, eu ainda estava fazendo scene-planning. Porque o Laerte atrasou o story-board, na verdade, só o Laerte ficou fazendo o story-board, no meio o Angeli jogou tudo em cima dele, ele se queixou até disso, quer dizer, a turma abandonou e o Laerte assumiu isso de uma forma muito bacana. Ele deu conta da coisa, a gente discutia, situações, mudanças, alterações. Esse prazo, ninguém estava me pressionando, nem a própria ANCINE. Você dá um prazo na ANCINE pro projeto, mas esse prazo também é flexível, você pode pleitear mais um mês, mais dois meses, eu não quis saber disso. Também não quis pedir mais dinheiro, justamente porque se eu pedisse mais prazo, precisaria de mais dinheiro e eu não sei se eles dariam. Mas a gente acabou fazendo o filme no prazo, não tive prejuízo, mas não consegui ganhar um tostão. Isso que é incrível. E a conta é tão fechada, na verdade, quem faz o orçamento são técnicos, pessoas especializadas, que a Cartoon me sugeriu, então ela fez todos os cálculos certinhos, e a coisa foi tão bem formatada, que terminou... você abre uma conta, e vc tem que zerar esta conta.

Então, são projetos interessantes, prá você se divertir, eu me diverti muito nesse projeto, os jovens que trabalharam também curtiram demais, a gente, eu dava risada nas sessões de pencil test, porque os diálogos são muito debochados, livre, era uma coisa tão livre que o filme não foi pro ar, é politicamente incorreto. Então, essa é a natureza do trabalho. São as coisas que valem a pena você fazer. Mas o preço que você paga é esse, não vai ter grana. Não vai ter prejuízo mas também não vai ter lucro...

ML - Vcs faziam animatic, pencil test? Como se faziam os Pencil tests? quem fazia? 
DM - Cada projeto tinha uma natureza, tinha um sistema de produção, que eu sempre fazia adaptações. Se pegar o "Los 3 amigos" como protótipo, que foi uma produção mais ampla, por exemplo...

ML - Eu preferia falar dos filmes da década de 1980, antes do computador.

DM - Bom, antes do computador, eu trabalhava com uma equipe fixa. Eu trabalhava menos com free-lancer e mais com a minha equipe. Eu sempre gostei de formar profissionais. Eu nunca gostei da idéia de trabalhar com freelancer, porque o freelancer vem com grandes virtudes, mas vem também com grandes defeitos, e às vezes vem com um tipo de trabalhoh que não se afina muito com o meu trabalho. É uma coisa muito pessoal também. E eu gostei muito sempre de formar jovens, aquela experiência diária, você vai formando, vc vai orientando, você acaba criando um profissional que trabalha, que faz aquilo que vc gosta e tal. Se bem que esses profissionais muitas vezes depois de formados, vão embora, vão até ser concorrentes. Mas isso é outra história. Sempre eu tinha um animador bom, da casa, cheguei a ter dois animadores, é acho que não mais do que 2 animadores, também eu tinha sempre 2 assistentes, prá cada animador, um intervalador ou in-betwener. E cleaner. Em geral, o trabalho de cleaner, esse é de free-lancer mesmo, é a última etapa do trabalho de desenho, é o cara que limpa o traço, e tal, né. E esse, sempre tinha muita gente na praça disponível, e aí vc podia escolher o melhor, então, eu gostava muito de trabalhar com freelancer. Se bem que eu tinha um aqui, que era o Borgui, que fazia um traço muito bonito. E eu tinha as moças que faziam a parte de arte-final. Nos tempos de produção maior, eu cheguei a ter umas 7 moças trabalhando.

O pencil-test era filmado, na época pré-computador. era filmado em $35 \mathrm{~mm}$ sempre, todo filme tinha pencil-test. Prá nós, ficou muito cômodo fazer pencil-test, porque eu tinha a câmera aqui, uma câmera alemã - eu trouxe 2 alemães aqui, o Sr. Kraiss, engenheiro proprietário da fábrica, prá montar a câmera aqui, Estou falando exatamente em 1985. Eu tinha essa câmera instalada na terceira casa, eu tinha uma mesa de edição, moviola, quer dizer, era muito fácil, eu tinha office-boy, era muito fácil dele ir ao laboratório, na Líder, na Revela; então, eu tinha uma pessoa que cuidava da câmera, que filmava, que cuidava da edição aqui dentro, que filmava os pencil tests, a gente só revelava, a gente via em negativo. Nos últimos tempos de filme, você levava um material hoje, e à noite, já estava revelado. Então, você podia ver com uma certa rapidez. Esse processo durou até 1985, porque logo depois, a gente comprou um gravador que apareceu na praça, um VHS, que gravava stopmotion, gravava os lay-outs, um gravador bom, aí, qualquer animador fazia isto. Não precisava mais do operador, do Nikolay, que fazia o sistema (de table top $35 \mathrm{~mm}$ ). Isso facilitou, porque qualquer hora que você queria um teste, você "rafeava" os lay-outs, os keyframes, ia nesse gravador, aí eles me chamavam prá ver, a gente discutia, então, ficou muito mais rápido o processo e muito mais eficiente. $\mathrm{E}$ mais barato, também. Você investia uma vez só em equipamento. Isso ficou durante muito tempo. Isso tudo, antes do processo digital, antes do computador.

Quando o computador chegou o computador, que era um 486, bem vagabundo, bem ordinário, então, a gente já digitalizava as imagens, cada um dos lay-outs, e salvava naqueles programinhas que a gente tinha na época, e você rodava e via no monitor a imagem pencil. Mas isso demorou um tempinho, isso foi em... eu me lembro que ek 1993, a gente não usava mais acetato, mais nada. 93 foi o ano passou a fazer pintura digital, escaneamento de imagem, e edição digital. Eu acredito que até 1992, 1991, a gente passou a usar este gravadorzinho. Esse sistema magnético era uma fita magnética VHS, era muito prático isso, colocava lá, dava um play, e você via a imagem em qualidade razoável. Então, os animadores começaram a se viciar muito nesse sistema porque ele não dependia de um técnico ou de um terceiro que nem sempre estava disponível. 
ML - Quem era o responsável pelo sincronismo com o som? A trilha chegava, alguém decupava... e quem juntava depois o magnético com o negativo? Quão pronto saía o material daqui para o Laboratório que ia fazer a cópia final?

DM - Tinha uma pessoa aqui dentro, ele conhecia tudo sobre a película sobre material, sobre edição, o Nicolay [Padalko], está comigo há mais de 20 anos, ele não desenha absolutamente nada, mas ele é fantasticamente eficiente em todas essas coisas... ele é cria minha aqui. Ele era encarregado de fazer este link entre o estúdio e o laboratório.

Então, na realidade, como a gente recebia o som - varia de filme prá filme: mas um filme que tivesse lip-sync, fala de personagem, sempre você pede antes os diálogos, em fita normal. A gente recebia este material, transcrevia isso prá uma fita perfurada, magnético perfurado, e, quase sempre eu, escolhia as sílabas que eram prá ser marcadas, quantificava isso em termos de frames, na moviola - era terrível o trabalho, porque na época não tinha esse esquema do computador, de fone, então, a gente se trancava na moviola e o som reverberava na firma inteira, ficava: "AH-AH-AO...", você ia marcando aquilo, era horrível mesmo- então eu marcava tudo isso e fazia uma ficha de animação, exposure sheet.

$\mathrm{Na}$ realidade, eu fazia isso em cima do projeto já pronto, que era o story-board com timming, eu sempre fazia o story-board e marcava o timming, a gente sabia onde era a pausa no story-board, onde começava e terminava a fala, etc. Se o filme tinha só diálogos, mesmo que tivesse som, etc, eu recebia só os diálogos inicialmente, mas já editava os diálogos dentro do tempo do filme, de acordo com o projeto, deixando os gaps, as pausas em branco e ia situando as falas no tempo exato previsto no story-board já. Em cima disso, e depois que ele media esses tempos, ele já podia fazer a ficha de animação. Porque a trilha sempre vem depois da animação pronta. Quando vc entrega o pencil test, mesmo tendo a camerazinha, quando a gente terminava a animação, a gente apresentava um projeto prá gravação da trilha, em pencil-test. Esse pencil test ia com os tempos, esses tempos eram tirados pelo estúdio de som, e eles gravavam a trilha sonora já em cima deste projeto. Esse trabalho todo era feito por um profissional; lidar com a película, com a filmagem, isso era feito pelo Nikolay. Então, terminando o filme, o que a gente mandava pro laboratório?

a gente filmava aqui, saía o rolo negativo, esse rolo negativo ia junto com o magnético perfurado pro laboratório, e lá eles faziam a transcrição prá ótico de som e tiravam o print final.

Em geral a gente também recebia o copião, sempre, se volta, esse copião era o material que a gente projetava na moviola, prá ver a qualidade dos efeitos do filme, quando estava OK, era o material que a gente apresentava prá agência. Aí tinha aquela reunião, porque a agência não tinha moviola, $35 \mathrm{~mm}$, eles tinham que vir aqui. Por isso que eu recebi muita gente aqui famosa até, eles tinham que vir ver o trabalho final, antes de aprovar, porque depois a etapa final eram as cópias em $16 \mathrm{~mm}$... A gente entegava em $16 \mathrm{~mm}$, isso, até a década de 1990, 90 e poucos, era $16 \mathrm{~mm}$. Em geral, a gente chamava de reduções, porque era tirado de um negativo $35 \mathrm{~mm}$...

ML - Vocês entregavam ao laboratório o filme em $35 \mathrm{~mm}$ e eles devolviam com som em $16 \mathrm{~mm}$ ?

DM - Sim, isso como print final, como cópia final. Nesse caso, a gente mandava prás agências que já tinham projetor, quase todas tinham projetor $16 \mathrm{~mm}$, e elas aprovavam ou não. Qase sempre não aprovavam, tinha um problema de um risquinho aqui, outro lá, se não tivesse, eles inventavam, prá gente tirar uma melhor e mandar prá eles. Esse é resumidamente o processo de produção inteiro.

ML - Quando adquiriu a máquina de xerox?

DM - São histórias interessantes, sabe? você tem tempo prá ouvir? Você sabe como surgiu a xerox? a xerox foi uma revolução, porque, realmente, o trabalho de fazer arte final, não era 
só o trabalho em si, porque tinha gente que fazia isso maravilhosamente bem, mas a maioria não tinha habilidade, porque isso precisa de uma destreza assim, de artista, um domínio, muito grande, e o acetato é uma mídia ingrata, difícil trabalhar. O animador ficava chateado, a gente ficava chateado, porque você via uma perda muito grande. de qualidade do trabalho. Então, quando a gente viu aquele filme "Os Dálmatas", o primeiro filme em que o Disney usou a xerox, foi um negócio, todo mundo "ah, puxa!". Aí, descobriram que só tinha um tipo de xerox que vc podia usar prá fazer este trabalho, que é a primeira xerox, a xerox antiga, chamava-se Xerox Standard, que foi fabricada em 1950, Por que que ela servia prá isso? Essa máquina não fundia, não tinha aquele fusor que esquentava, que as outras máquinas têm, um sistema de aquecimento muito grande que torrava o acetato, essa máquina não tinha e o acetato não corria, como o papel, dentro da máquina. Ao contrário, era um sistema, parece que era um tipo um scanner, que passava em cima, pelo negócio eletrostático, enfim, era uma geringonça enorme, era uma máquina, ocupava uma sala. Acontece que essa máquina era um dinossauro perdido lá na década de 1950, então, ninguém tinha essa máquina. Todo mundo saiu correndo à procura, comprar uma, então, os meus colegas foram muito mais rápidos do que eu, eles conseguiram descobrir algumas no interior de São Paulo, uma outra perdida lá não sei onde... em Maceió, quer dizer, eram meia dúzia de máquinas que todo mundo comprou. Eu não consegui comprar. Então o que que eu fiz: eu comprei uma xerox comum, standard, e passei a usar ela, não sei nem como, não era nem xerox, era uma outra marca, que ela conseguia passar também o acetato, mas depois você tinh que "repinar", cortar os acetatos e colocar os pinos, um a um, baseado no desenho, quer dizer...

\section{ML - Não era perigoso perder o registro?}

DM - Era, perdia-se muito o registro, quer dizer, na realidade a gente trabalhava com papel embaixo, colocava papel, o acetato em cima e o rapaz colava cada folha com durex, era um trabalhão terrível. E essa Standard, não precisava fazer isso. Mas isso durou pouco, porque logo a Xerox começou a fabricar máquinas fantásticas, sabe? E eu comprei uma, e era bem menor do que as outras. E quem tinha aquela standard acabou ficando com um trambolho, não sabia o que fazer com aquilo. Eu tenho a impressão de que isso deve ter acontecido ao final da década de 1970. Eu tô falando de 1979, por aí. Foi uma revolução, na época realmente foi. Aí, todo mundo falava: "não, mas, você vai instalar uma Xerox?" Eu tinha essa percepção. E você vai dispensar todas as suas funcionárias, eram todas mocinhas fazendo arte-final... "Não, não vai. Quem vai pintar? Porque a produção vai ser maior agora". Se você tem uma xerox, vc tem muito mais acetatos. Então, vc vai precisar muito mais dessas moças pintando. Foi exatamente o que aconteceu. $E$ elas passaram a fazer também 0 trabalho da Xerox, de operar a máquina, de limpar também, que era um trabalhão.

\section{ML - Vocês reutilizavam acetato?}

DM - Jamais eu fiz isso. Nunca. Não dá, sabe por quê? Era inviável isso, porque antes, a gente usava uma caneta no acetato, se vc limpasse, lavasse - o que tira toda a transparência - você deixava um sulco no acetato, e aquele sulco aparecia. Se bem fotografado, ele aparecia. Depois, se usou a xerox, que você limpava mais facilmente. Mas a tinta que se passava atrás era a Selvinil, que era uma tinta importada, que é uma tinta que parece um suvinil, aquilo você não consegue extrair, se você arrancar aquilo, vc arranca o acetato inteiro. E uma coisa é vc trabalhar no acetato limpo. É uma coisa que dá até prazer. Outra coisa é você pegar um acetato limpo, lavado, ele deixa marcas, e a gente tinha uma câmera muito boa, ela capturava todas essas imperfeições. O acetato era importado. $\mathrm{Na}$ realidade, era um tri acetato, era muito caro, era na base de $U \$ 1,00$ cada folha, já vinha no formato. Primeiro, a gente importava da Inglaterra, chamada chromacolour. Depois dos EUA. cartooncolour. Vinha em bloquinhos, e era muito caro por causa do peso. Nunca, nunca houve um fabricante nacional. Uma pena, porque era um mercado crescente. Mas nunca 
houve... nem prá isso, nem prá tinta...prá nada. Nós perfurávamos aqui, a gente teve até 3 perfuradoras.

ML - E a assistência técnica? quem consertava ou afiava a perfuradora?

DM - Essas são dificuldades comezinhas, mas, no caso de uma perfuradora, eu importei uma inglesa ótima, pesadona, ela está perfeita até hoje. E eu importei essa máquina no início da década de 1970. Está em casa ela. É perfeita, nunca precisou de um ajuste, nada disso. E tinha outra, que está até com um amigo, feita por um russo, que tinha uma oficina aqui no Brasil, se chamava Markian, e ele fornecia essas máquinas prá todo mundo. Ele tinha uma pequena siderurgia. Ele foi o único que fabrircava alguma coisa assim prá animação, reguinhas de animação, discos, essas coisinhas, ele andou fazendo uma incursão nesse negócio. Eu nunca tive problema com essas furadoras, por incrível que pareça. Depois apareceu um outro rapaz, que era um ex-funcionário dele também, que prestava pequenos serviços de... mas era uma dificuldade, porque, se quebrasse um desses aí, acabou. Se quebrasse realmente, porque não havia know-how. Parece simples a coisa, mas é uma engenharia de plrecisão. Há uma diferença entre uma furadora assim... milésimo de milímetro, se ela não estiver bem ajustada, quando você colocar o papel, ele cria um abaolado assim, sabe, é horrível e isso acontece com o produto nacional, né? Então, eu nunca usava isso, esses discos todos são importados... você paga um pouquinho mais pelo produto importado, mas você tem a tranquilidade. Esse é um investimento que vale a pena, realmente, se vc puder fazer, do que usar o nacional, então, eu sempre tive isso importado.

ML - Agora, vamos entrar na fase dos computadores.

DM - Eu sou meio zero à esquerda nisso...

ML - Quando ouviu falar pela primeira vez que o computador poderia entrar nas empresas de animação, poderia ajudar em alguma parte dos processos? Pensou que isso poderia ajudar ou trazer mais problemas?

DM - Eu acho que foi nessa época do final dos anos 80, que eu comecei a ver as primeiras experiências feitas pela Globo. A Globo começou a fazer umas vinhetazinhas que usavam computador, e tal. Então, é engraçado, que havia um temor aqui, eu tinha uma equipe já, que tinha um medo tremendo, porque todo animador, ainda hoje tem, e... quando eu falo animador, estou me referindo ao animador tradicional, todo cara que desenha bem 2D, então, a gente ficava com muito medo que o computador viesse tirar o emprego deles. Eu me recordo de um animador que eu tive aqui, o Caldeirão, muito bom animador, por sinal, ou era bom animador na época, Alexandre Calheiros, ele entrou na minha sala apavorado, "Ô, Daniel, que será que vai acontecer com a gente agora?", eu falei: "só pode acontecer coisa boa, porque o computador não vai substituir a animação tradicional, ou não vai pelo menos substituir o trabalho do animador tradicional, porque a animação 2D é o fundamento." Os princípios básicos foram forjados pela animação tradicional, pela mão do animador tradicional. É uma arte que usa ferramentas diversas. Essas ferramentas estão se hiper especializando.

O computador é uma ferramenta ultra-sofisticada que não vai substituir o animador. Hoje, mais do que nunca, se precisa do animador, do cara que desenha, que desenha bem o cartoon tradicional. Esse pessoal está sendo absorvido pela indústria da animação 3D, todos eles. Inclusive, se vc ver, o approach, o estilo de animação 3D hoje, qual é o ideal estético? É reproduzir aquela estética disneyana, quer dizer, o cartoon, as figuras, o timming, o gestual todinho, stagging, tudo, tudinho. Claro, com uma ferramenta ultra-sofisticada.

Mas esse temor havia muito na época. Honestamente, eu saudei assim com muita tranquilidade, muito otimismo, porque eu comecei a ver que o computador estava sendo... e eu comecei a ler bastante. 
Eu lia muito sobre animação que o computador estava também sendo aplicado nos processos corriqueiros de trabalho, como na pintura, no scanning, na edição final do projeto, então, isso veio a facilitar demais a vida no processo de produção 2D. Não havia este temor, eu nunca senti temor pela coisa. Tanto assim, que fomos absorvendo. Só que eu comentava sempre: "a gente tem que aceitar as mudanças e se atualizar. Você tem que estar pronto para se adaptar e assumir a mudança onde ela for interessante prá você.

Por exemplo o processo do acetato: é terrivelmente penoso, é imperfeito, você sabe, às vezes vc precisa colocar 6 acetatos, 6 layers de acetato num take qualquer, o último de baixo a cor já é totalmente alterada, ele perdeu a chroma real dele. Com os outros níveis, ele perde transparência. Então, isso acabou.

O computador, vc edita isso no After, você pode colocar 200 layers se vc quiser, eles são integrais, são puros lá. Edição também: você não tem mais que cortar negativo e montar e colar, isso é uma coisa absurda. O computador fez todos esses trabalhos de rotina, e eu estou falando só na animação $2 \mathrm{D}$, tradicional, a gente passou a usar isso com um conforto tremendo, sem falar também no som, por exemplo, nos efeitos, na própria animação adaptada, animação 3D adaptada a 2D, por exemplo, de repente você tem uma embalagem ultra-sofisticada, que vc não podia animar, um personagem, que era muito complicada a forma. Então, a gente passou a animar essas imagens em 3D, junto com 2D. Essa passagem prá mim foi muito tranquila, e eu soube aproveitar bem, tirar partido do computador, não foi traumática. Embora a visão fosse essa, "tá chegando um espantalho, a máquina que vai substituir o..." O computador é burro! Ele só funciona se tiver alguém inteligente, entendeu, ou supostamente inteligente, operando esta máquina. É uma ferramenta. Se não tiver, você não extrai absolutamente nada. As melhores animações em 3D têm um cara criativo inteligente atrás dela, seja qual software for. Não adianta: automaticamente você não dá uma ordem e o computador sai animando. Se fosse assim, não haveria mais bons animadores $3 \mathrm{D}$, e hoje existem.

\section{ML - Quando o seu estúdio adquiriu o primeiro computador?}

DM - Acho que era um 486, faz tanto tempo isso; na época, o meu sonho era ter um Sillicon Graphics. Mas Sillicon Graphics era uma máquina, sabe... a Globo tinha. Então, era uma máquina inaccessível, prá mim pelo menos e prá maioria dos pequenos estúdios, era inaccessível, era muito caro. Então, a gente foi lutando e sonhando em ter uma máquina e de repente começarm a aparecer representantes, com pequenas workstations, aquelas maquininhas adaptadas, aqueles programas muito vagabundos, Topas, Tips. Isso foi assim comecinho da década de 1990, final da década de 1980, aí, a gente entrou nessa, comprava um, comprava outro, ia ficando velho e ia substituindo esses programas, mas a gente nunca teve um sillicon graphics, que era uma espécie de mercedes benz dos computadores, workstation, mas também esses computadores começaram a perder terreno para os Mac Intoshs, pra os PCs da vida, que foram ficando cada vez mais rápidos, melhores processadores, e aumentando a memória, também vc ter a possibilidade de ampliar essa memória... e de repente, hoje todo mundo tem PC, ou Mac, mas ninguém mais fala em Sillicon Graphics. Ficou meio que perdido na... então, eu acho que... te falar o ano exactamente... acho que foi todo mundo no mesmo ano, sabe?

Mas eu me lembro de uma data que é muito significativa, que foi o seguinte, foi em 1993: em 93, eu tive que me decidir, eu não ia continuar claro... eu ia ter que entrar na pintura digital, scaner e pintura digital. Então, a gente recebeu uma carta de um fabricante americano chamado AXA, ninguém tinha esse equipamento aqui - ninguém tinha.

Eles tinham já lançado um programa, que era a versão $n^{\circ} 1$, e eu tinha ouvido falar, acho que por alguém da TV Cultura, que o programa não era bom, a versão $n^{0} 1$ dava muito pixel, o traço era terrível. O que a gente queria usar era justamente escanear e fazer a pintura digital e ele já tinha tudo, os módulos prá pencil test, prá tudo. Pintava tudo individualmente, um por um. Depois, nas outras versões, aí sim, mas não existe mais o programa, o ToonBoom hoje faz isso também, pinta direitinho. Mas naquela época, a gente já usava pintura digital, mas era uma adaptação, uma gambiarra, a gente usava um programa chamado Tips, 
QUE FAZIA UMA PINTURA DIGITAL, mas era uma pintura muito... vc tinha que importar pro programa prá render, era um negócio complicado realmente, esse programa já tinha tudo prá vc render lá, vc já escaneava, vc já pintava, programava ficha, e você já pintava lá, vc fazia tudo. Tinha até um módulo de edição também, mas a gente não comprou.

E como saber se a versão 2 era boa? O cara era um fabricante pequenininho lá, nos EUA, ele garantiu prá gente que a versão era boa realmente. Mas ninguém sabia, então, não tinha uma pessoa no Brasil prá gente apelar. Porque era caro o programa, custava US\$10.000!

Eu falei assim: "vamos comprar." Prá nós, não era fácil a decisão, US\$10.000 não era brincadeira não. Você sabe que, quando chegou aqui e a gente instalou, e isso eu tenho certeza, que a gente foi a primeira produtora, porque a TV cultura veio logo em seguida, depois que a gente tinha instalado, logo em seguida, saber como funcionava, se era bom e tal... e era bom, realmente ele funcionou direitinho... então, esse ano foi 1993. Foi o ano em que a gente substituiu definitivamente e profissionalmente por um programa exclusivo de pintura digital feito pra animação.

ML - Vocês compraram o computador e o scanner junto?

DM - Sim.

ML - E a função do computador era ajudar na animação 2D inicialmente, ou vocês já, ou vocês já pensavam em animação 3D?

DM - A gente já estava pensando nisso também, mas era uma hipótese ainda, pra nós, remota fazer 3D. Na realidade, o que eu queria era usar o computador, eu não tinha ainda pensado em fazer 3D. Depois, 3D virou banal. Quer dizer, todo mundo passou a fazer 3D, lógico. Inclusive os profissionais da área começaram a ficar muito mais experts em 3D do que em 2D. Hoje, você encontra mais profissional ligado à produção $3 \mathrm{D}$, ou $2 \mathrm{D}$ vetorizada, do que animação 2D tradicional, aquele animador que não conhece nada de computador. Quer dizer, não existe mais esse...

ML - o software AXA foi instalado em um computador que vocês já tinham ou precisaram comprar um equipamento novo?

DM - Nessa fase, a gente estava canibalizando e comprando equipamento novo. Porque realmente as mudanças eram muito sérias e muito rápidas, então, com certeza a gente comprou um computador novo. $\mathrm{Na}$ verdade, a gente foi comprando aqueles processadores... saía um um pouco mais sofisticado, uma coisa mais, Intel da vida, e a gente ia adquirindo esses softwares. Eu só me lembro que eu fiquei muito chateado tempos depois porque a gente pagou uma fortuna por esse AXA, na verdade não era US $\$ 10.000$, era US\$ 8.000 e poucos dólares. Porque eram diversos módulos assim, e eram módulos independentes entre si, tal, e eu vi esses programinhas na Sta. Ifigênia por $R \$ 40,00$. Como também os programas 3D. Antes, você tinha que importar, era coisa de US $\$ 20.000 \ldots$ aquele Soft Image, primeira versão era US\$25.000. Todos eles eram muito caros. O ToonBoom mesmo foi lançado por US\$15.000. Hoje, já está US\$7.000, US\$ 5.000. Enfim, a tendência de software é baixar. Pagando o investimento na engenharia do software, eles vão baixando de preço. Mas vc encontra essas coisas todas assim na Sta. Ifigênia. O que não é bom, sabe?

O mercado acaba se ajustando à realidade, através desse tipo de atividade, porque os preços dos softwares oficiais são inacessíveis. Ainda hoje, a maioria das pequenas produtoras, e ninguém nasce grande produtora, a não ser que alguém se instale com capital estrangeiro, monte uma filial aqui... normalmente as pequenas produtoras começam com pequenos núcleos, é um profissional associado a outro, isso é muito comum, ou a 3,4 profissionais... que formam uma home-office, uma pequena produtora trabalha em casa mesmo, numa máquina, e tem um certo acesso a um cliente; em geral esse pessoal não sai 
assim com US $\$ 500.000$ iniciais, não tem esse dinheiro pra bancar, eles vão apelar pra esse tipo de... o mercado, a produção roda assim, eles vão na Sta. Ifigênia e fazem a limpeza lá de software. É bom? é claro que não é bom. Primeiro tem esse problema de ser ilegal. Segundo, eles não têm assistência técnica nenhuma. Terceiro, eles não têm como fazer o update deste programa porque não é oficial. E quanto, porque é uma porcaria, quer dizer, o que os caras vendem lá em geral é tudo com bug, com coisa que não funciona.

\section{ML - Quem foi designado a aprender a lidar com o equipamento novo?}

DM - Foi o Nikolay, o Nicolay é um santo, aquilo que eu falei no comecinho, que eu sempre gostei de formar profissionais, o Nikolay tem esse perfil , ele começou aqui muito jovem, ele tinha acabado de sair do exército, ele morava aqui em frente, e eu precisava de alguém pra fotografar, naquela época, eu fazia o story-board, e fotografava com uma foto de altocontraste, no papel fotográfico mesmo, o negócio ficava bonito, e eu pintava com ecoline, mas o papel era muito brilhante, e nós descobrimos que se vc fizesse um suco de batata, não sei por quê, vc passava na folha do papel fotográfico, ele ficava meio opaco e podia receber bem a ...

\section{ML - Papel fotográfico revelado?}

DM - Eram chapas de papel tudo importado, eu tinha uma máquina enorme, uma espécie de ampliadora. Vc colocava a chapa colocava o desenho e ele imprimia por contacto, então, ficava o negativo. Mas a gente pintava esse negativo, péra um pouco... tinha na realidade, o fotolito, a gente fazia uma transparência, mas tinha também o positivo... deixa eu tentar lembrar... eu estou tentando me lembrar do processo... esse prossesso do papel, ãh... a gente imprimia isso em papel... acho que ele fotografava realmente e a gente ampliava em papel... mas a gente tem uma cozinha e fazia um suco de batata, e a gente passava isso no papel, e esperava secar. QUando secava, vc vinha com ecoline - eu adorava, sempre adorei trabalhar com ecoline, e coloria. Ficava muito bonito, ficava brilhante, com as cores bonitas. Ele recortava e montava, porque eram story-boards grandes, era uma coisa mais de "show" pra agência, do que uma coisa técnica, porque o story-board não tem essa função, mas vc nunca conseguiria vender um story-board como a gente deve fazer, uma coisa rough, mas que tenha todas as instruções técnicas de transição, vc não consegue vender isso pra um cliente que não conhece nada do processo, e quer ser, digamos impressionado, cliente que está lá pra ver resultado já.

Então, a agência tb estimulava muito isso, story-boards bonitos, então, eu treinei essa pessoa pra fazer isso. Ele fazia tudo isso bonitinho, depois montava. Então, era uma pessoa muito dedicada a todas essas funções técnicas, e muito talentoso pra isso, prá trabalhar com a película, então era um homem assim de sete- instrumentos; na época era importante, você podia ter 10 pessoas pra fazer 10 funções, seria óptimo, se tivesse capital, mas eu não tinha, então, uma pessoa fazia tudo, e acabou sendo muito bom prá ele porque ele se formou um profissional excelente e multi-facetado.

E quando apareceu o computador, ele era a pessoa naturalmente talhada pra fazer isso, pra ir se especializar, em computador, em software, em tudo. Só que não fez sozinho, porque o computador começou também a ficar muito segmentado, aí, já era serviço de freelancers. Eu cheguei a ter duas pessoas que faziam o mesmo trabalho que o Nicolay fazia, e aí ficaram realmente caras demais. Porque o tempo ocioso entre um projecto e outro começou a aumentar, e aí começou a ficar muito caro, inviável você manter funcionários numa equipe fixa.

ML - Como o computador se integrou à rotina da equipe, quais suas funções?

DM - Sobre as funções que o computador exercia no início, tem um detalhe pequenininho: como eu sempre li bastante sobre a produção lá fora, eu estava muito atualizado sobre o mercado, o mercado americano, por exemplo; por um bom período de tempo ele ficou meio 
estagnado, então, o processo de produção nacional quase que se equiparou ao processo da produção americana, na fase anterior ao computador, digamos, em processo de produção, e em matéria de resultados também, tirando, lógico, aquelas coisas brilhantes da Disney, a indústria milionária da produção, mas o resto ficou muito equiparado. De repente, o computador surgiu e a distância aumentou bastante, distância qualitativa ficou incansável. Ficou uma coisa de tecnologia muito avançada. No caso, as primeiras funções (do computador) elas foram surgindo meio que naturalmente.

Então, o que eu queria mais, e eu fiz muito empenho nisso, é que o pessoal que já trabalhava comigo em funções como, por exemplo pintura e arte- final, que esse pessoal fosse integrado à rotina do computador. Eram moças, só moças. Elas poderiam fazer o scanner, a pintura digital, podiam até fazer animação, se quisessem, fazer background, cenografia, tudo, no photoshop, já. Isso, a gente estava passando por esse processo e eu estava preocupado porque a gente ia ter que abrir mão de moças, e há um processo afectivo. Acaba sempre havendo gente que trabalha há 10 anos, e tal, $E$ eu sempre procurava influenciá-las no sentido de: "olha, existem cursos, vocês devem fazer esses cursos, procurar se integrar", mas não houve interesse, talvez pela natureza do trabalho, qual a maioria se dedicava mais à pintura, não houve interesse, então a maioria das pessoas que eu tive que absorver era gente nova no mercado, e essas pessoas foram saindo, gente que trabalhava há muito tempo em pintura... sabe, eu tive um cara que hoje é um grande ilustrador, o Cárcamo, ele foi meu centrista aqui, tal, e continua hoje fazendo coisas marravilhosas de aquarela, e tudo.

Mas ele foi desses caras que não quiseram nada com computador também, sabe? Ele sempre se deu muito bem no sistema tradicional de pintura. As outras mocinhas não, quer dizer, o pessoal não se adaptou. E eu achava chato isso, porque vc tinha novas pessoas que vc tinha que treinar novamente. Eu também estava aprendendo a lidar com computador, a mexer com a nova tecnologia, mas esse pessoal foi mudando, foi mudando a cara.

ML - Mas se o senhor tinham 5 ou 6 moças que coloriam, acho que 2 no máximo iam dar conta de fazer todo trabalho, não? Algumas iam necessariamente cair fora.

DM - Sim, exactamente. Na realidade, logo no primeiro momento - engraçado isso, você vê: eu cheguei a ter mais. Eu falei 5 ou 6 , às vezes tinham as freelancers que vinham. Então, você chegava num sábado aqui tinha 10 pessoas pintando acetato, porque o processo, você sabe, os prazos eram sempre muito curtos, e ia afundilando o prazo, quer dizer, sobrava prá arte-final, em acetatos, né, que era a pintura. Em geral, o prazo que elas tinham, era muito pequeno, acabava sendo assim, às vezes um filme de 15, 20 dias de prazo, acabava sendo 3, 4 dias pra se terminar um projecto. Então, enchia de gente pintando acetato, quer dizer, o trabalho que esse pessoal todinho fazia, que às vezes demorava 4, 5 dias, no começo, um homem só, o Nicolay, uma pessoa só fazia isso num dia tranquilamente, era clicar - shuip - e está pintado. É um ato praticamente instantâneo, 2, 3 clics, e você está pintando um acetato. $\mathrm{E}$ aquilo era um trabalho de pintar, deixar secar... por isso que eu saudei assim de uma forma muito optimista o advento do computador. Eu não vi um problema nisso.

Mas, que mudou a cara, mudou a cara realmente. Você passou a trabalhar com... você tinha cenários que eram feitos em guache, ecoline, às vezes em acrílico, de repente passaram a ser feitos no photoshop.

Num primeiro momento, eu não tinha ninguém pra fazer isso, eu não sabia, se sabia de alguém que trabalhava muito bem com ilustração, no photoshop, um freelancer, aí chamava o freelancer, e fazia; às vezes eu tinha que fazer o lay-out em ecoline, um rough de cor, pra ele fazer aquilo no photoshop. Imagina, hoje quando eu vejo isso, photoshop, qualquer criança sabe mexer, mas na época, ninguém sabia aqui. O Nicolay se especializou em softwares, não de ilustração, sabe, então precisava de um ilustrador realmente... e depois foi fácill arrumar. E eu acabei fazendo muita coisa também. 
ML - e ocorria a vocês fundir traço a mão, ecoline... essas possibilidades que foram criadas pela computação? Ou seja, dar um aspecto de "feito a mão"? Eu imagino que num primeiro momento houve muitas pessoas recorrendo a um visual mais "clean", mais liso, do computador, e depois, pareceu-me que as pessoas foram redescobrindo a textura; não sei se aconteceu isso...

DM - Exactamente, isso aconteceu gradualmente, num primeiro momento o computador não fazia isso. Inclusive, havia muito pouco softweares de pintura voltados à animação. Porque o grande mercado não era a animação. O grande mercado ou era a animação $3 D$, que era o CGI, animação gerada no computador, então, isso era uma coisa, não era o nosso universo ainda, mas não havia sofTwares que simulassem isso ainda, num primeiro momento, que vc pudesse trabalhar a animação legal. Talvez até houvesse, mas não estavam assim acessíveis. Com o tempo, a gente foi tirando partido desse material. A gente foi aproveitando tudo o que o computador podia oferecer de interessante. A gente foi ousando, fazendo animações, mesmo usando esses softs, mas isso veio chegando mais tardiamente. Não foi algo assim, no primeiro momento. No primeiro momento, os softwares de pintura eram softwares duros assim, o $A X A$, o Toonz, tinha que fazer traço fechado, se não fechasse muito o traço, ese estourava, abria, vc tinha que dar o control_Z, retocar, quer dizer, essas coisas todas foram ganhando sofisticação, o Toon-Boom hoje, vc pinta, tem texturas diferentes, faz manchas, e vc pode simular muito bem a pintura real, pintura de aquarela...

ML - Em quanto tempo vc se lembra que o sistema analógico foi totalmente substituído pelo digital? Em quanto tempo vocês abandonaram de vez?

DM - Sistema analógico, depende: a gente não deixou de fazer animação... aí é que tem que definir o que é o sistema analógico: se você se referir à película, ao cinema, eu te digo que em 1995 já não tinha mais nada aqui. Eu doei uma câmera, um stand de animação e uma mesa editora de moviola, que eu tinha gasto mais de US\$100.000. A câmera - que eu te falei, eu chamei 2 técnicos alemães pra instalar uma câmera ligada a computador, funcionava com um sistema de computadores de pulso, faziam o movimento programado, Eu criei isso em 1985. Em 1995, isso já não tinha mais utilidade nenhuma. Eu não estava mais usando acetato, não estava mais usando tinta, não estava mais usando edição analógica, Só digital, tudinho, só computador, e eu tinha aquele trambolho enorme. A moviola ocupava metade desta sala e o stand de animação ocupava uma sala com $5 \mathrm{~m}$ de altura. Coloquei no jornal pra alguém que não fosse usar este material comercialmente, esta eta uma condição sine-qua-non, quer dizer, pra fins didácticos, beneficentes, e doei tudo. $E$ quem se apresentou melhor, que eu achei que merecia isso, foi o Wilson Lazaretti, de Campinas. Foi um equipamento caríssimo, sabe? A moviola custou US\$11.000, e a câmera tinha 1000 recursos, tinha projecção, pra imagem aérea, tinha Bi-pacK, era uma câmera fantástica. Tinha floating peg-bar, que era um negócio que, um pino que corria aéreo, corria independente da câmera, vc podia fazer um movimento de $360^{\circ}$, era uma coisa que nenhuma câmera aqui tinha. Tinha pantógrafo... De repente, vc fazia tudo isso, sabe, com o After você fazia isso tranquilo. O computador passou a ser o editor, o trabalho de câmera, tava tudo concentrado ali na CPU. E pra que se precisava de tudo isso, não? Ficava lá ocupando espaço. Tive que doar, então é uma pena, mas, enfim...

ML - Quando vcs perceberam que a configuração do estúdio tinha que mudar, isso foi mais uma necessidade interna de vocês, essa percepção, ou isso também fazia parte de uma demada das agências?

DM - Havia as duas coisas. De um lado, internamente, a gente estava percebendo a mudança lá fora. Eu sempre importei muito livro e via que as coisas estavam mudando lá, qualitativamente, pra começar. Os comerciais americanos, europeus, eles vinham com uma qualidade extra, sabe, e essa qualidade implicava novas ferramentas, eles estavam usando 
novas ferramentas, e essas novidades estavam chegando às agências, lógico, as agências naquela época, quase todas eram estrangeiras, hoje, já são todas. Mas naquela época, eram quase todas. Então, eles recebiam muito das matrizes, recomendações, exemplos de boa animação, de bons comerciais, comerciais criativos, propostas diferentes; vc não podia mais obter este resultado com as ferramentas tradicionais. Não adiantava uma câmera que era um mostrengo daqueles, que não fazia o que fazia o After Effects. O último relesse dele, coisas fantásticas, multiplane, Tudo que se consegue hoje com o After, essa multiplicidade de layers, se consegue com muito mais facilidade e muito mais layers. Na multiplane do Disney cabiam 8 layers, níveis de profundidade. No After, vc consegue um número infinito de layers. Você pode ir multiplicando os layers e cada um deles é independente, tem o mesmo efeito de profundidade, e de uma forma mais limpa, mais complexa, movimentos muito mais sofisticados, zoons que vc não podia fazer por uma limitação mecânica, de repente vc começar a fazer zoom perpétuo, por exemplo, vc começa do cosmos, e vc vai até a cabeça de um alfinete, tudo isso, com os softwares novos vc conseguia; no começo a gente já sabia disso, na década de 1990, a gente já estava sabendo disso tudo, só que não havia dinheiro prá se comprar um Soft Image, por US\$ 25.000, um hardware de US\$50.000, como era o Sillicon Graphics.

E essas coisas estavam chegando no Brasil. Estavam se tornando mais baratas lá fora, e começavam a ficar mais baratas no Brasil também. Quando isso começou a baratear, já na $2^{a}$ metade da década de 1990 , aí, todo mundo começou a comprar, e nós também. Acho que foi um processo simultâneo. Não foi uma coisa que se fala assim: "opa, é agora", e no dia seguinte vc passa a comprar o software, não é assim. A coisa foi correndo simultaneamente. As produtoras que não investiam, elas iam ficando velhas e iam saindo do mercado, iam desaparecendo; na agência se sentia isso, eles estavam cobrando isso também, sabe? Quer dizer, o pessoal estava cobrando novidades, então, tá na hora de fazer a coisa.

ML - essa mudança no modo de produção se reflete nos orçamentos, não?

DM - Deveria. Mas não houve grande mudança; olha, por exemplo, eu cobrava US\$1000 (por segundo), hoje seria $R \$ 60.000,00$, não é? Eu acho que eu nunca consegui cobrar mais do que $R \$ 65.000$ num filme de 30 segundos. Nunca, jamais.

ML - Mas, num tempo em que havia 15,16 pessoas trabalhando, cobrar $\mathrm{R} \$ 60.000$, e hoje, com menos pessoas trabalhando, ficou, por assim dizer, mais lucrativo, ou não?

DM - Essa coisa de ter menos gente não corresponde à realidade, você não faz com menos gente um projeto de animação. Um filme de $30 \mathrm{seg}$, seja o filme que for, ele vai ter um, hoje em dia, principalmente hoje em dia está muito segmentado, raramente você tem a história do factotum, do cara que vai fazer o story-board, a animação, cria o som, vai filmar, escanear o material, pintar...

ML - O comercial vira um filme de autor...

DM - Não existe mais isso, você pode talvez... um filme de autor, por exemplo o Bill Plimpton, aquele que faz o desenho sobre, eu fiz até um filme chamado Dinda's, muito baseado no desenho dele; eu me entusiasmei, ele fez tudo em lápis de cor, sobre o papel, eu achei que isso era uma coisa fantástica prá realidade brasileira, sem grandes orçamentos, etc, mas um comercial é uma produção sofisticada. Então, ela exige especialização. Você tem que ter um bom roteirista, um story-boardista, vamos falar de animação 2D tradicional, aí vc vai ter, no mínimo, um bom diretor, que é caro, vc vai ter um bom aniador, que é caro, esse animador vai ter que trabalhar com, no mínimo 2 assistentes, intervaladores, no mínimo 3 cleaners, tô falando uma produção normal, um trabalho médio, nada sofisticado, nem nada muito simples. Aí já entra na área digital. Você vai ter alguém que faça o escaneamento da imagem, alguém que faça a pintura digital, talvez, algum desses cargos se sobreponham, mas o normal é que o editor só faça edição de imagem. Se tiver alguma 
animação 3D, tá aumentando a equipe, né? Animação 3D sempre tem, 'as vezes uma figura em 2D tradicional um cartoonzão, aquela figura criada pelo Laerte de repente tosca, está pegando uma embalagem supersofisticada em 3D.

Então, essa animação não é um cartunista 2D quem vai fazer, é o animador $3 \mathrm{D}$. E se tiver que fazer rigging, modelagem, etc, é uma outra pessoa. E vai por aí a diante. Talvez vá ter alguém prá fazer a parte conceitual, se tiver grandes backgrounds, pintura, etc... vc está vendo como a equipe é grande? Depois, se vc somar tudo isso, por mais que vc tenha feito o cálculo no lápis, vai dar sempre um pouco mais do que aquilo que vc calculou. Normalmente, o orçamento hj deveria ser muito mais alto. Mas o mercado não responde a isso. Esse que é o problema. As coisas não sobem simultaneamente, tudo, subiu também o faturamento das empresas... vc consegue, naturalmente, num filme 3D, uma coisa um pouquinho mais alta do que isso. Você consegue $R \$ 80.000$, tal. Mas o custo deles vai ser tb mito mais alto.

Enfim, é uma ilusão muito generalizada, muito difundida, sabe, não só pelo estudioso, mas também pelo profissional que está na agência hoje, pensar que o computador diminuiu a equipe. Eu me lembro de uma diretora famosa, dona de uma agência hoje, que me pegou no corredor, na agência, e falou assim: "Bem, Daniel, então hoje o computador está fazendo tudo né?" Eu falei:"não é bem assim". Tarefas de rotina ele faz maravilhosamente bem, e veio a ajudar muito a produção, eu sempre me refiro à animação 2D. Agora, a parte criativa, a parte inteligente da produção, e a parte que depende de skill, de talento, essa parte continua sendo exercida pelo profissional. Não tem jeito. Ela falou: "mas como assim? o computador não faz tudo?" "Não, o trabalho da animação e da assistência da animação, direção, cenografia, etc, ainda é desenvolvida pelo profissional. A parte de edição, de pintura digital, não tem mais acetato, não tem mais câmera, isso acabou tudo." Ela falou: "Então o computador faz quase tudo?" eu respondi: "É, mais ou menos isso..." (risos). É difícil...

Ainda hoje existe uma percepção equivocada de que o computador veio prá abreviar prazos, prá diminuir custos, prá modernizar e prá resolver tudo na imagem, não é verdade isso. Computador é uma ferramenta fantástica, é uma revolução - não é só uma revolução, na produção de imagem, é uma revolução em geral, em todo o processo, cultural, é uma revolução cultural, fantástica, mas ela depende ainda da inteligência do homem do talento do profissional prá operar essa máquina e tirar grandes resultados. É nisso que um trabalho se diferencia de outro, que ele usou um software melhor, ou não. Os softwares estão ao alcance de todos, e logo eles vão ser muito mais acessíveis, tanto que a tendência do preço é diminuir fatalmente. Agora, o que diferencia é a individualidade, a personalidade do artista, a maneira dele encarar um projeto, dele colocar o seu talento individual, sua visão do trabalho.

$\mathrm{Na}$ questão de direção de arte, por exemplo, houve também muita cooperação, e também o nascimento de novos profissionais que se ajustaram aos softwares. Isso foi muito bom. Na realidade, o computador teve esse condão; uma das coisas fantásticas que veio, com a revolução, foi democratizar custos de certos equipamentos. Parece uma coisa boba, mas você pintar com tinta acrílica, material importado, vc teria que fazer um cenário com tinta, por exemplo, dependia de uma escola tradicional de pintura que nem todo mundo tinha acesso, pincéis caríssimos, tudo, quer dizer... de repente os softwares estão muito baratos e acessíveis a todo mundo, então, começou a muita gente ilustrar bem. Então, vc tem uma oferta hoje de grandes ilustradores prá trabalhar em backgrounds, fazer cenários, direção de arte mesmo ou colaborar com o projeto que antes não eram tão disponíveis assim. Quer dizer, esta também é uma qualidade da revolução. uma das consequências positivas da revolução. Eu acho que realmente todo mundo ganhou. Há muita lenda realmente, muita versão equivocada, dos milagres do computador, mas realmente o saldo é muito positivo. Você vê na qualidade da imagem, Você vê que houve uma evolução no material. Até em coisas simples, como a qualidade sonora, trilha sonora, o som hoje digital é muito mais limpo, mais cristalino, mais potente. Digo broadcast, na reprodução na televisão, a qualidade da imagem, não vêm mais aquelas sujeiras que vinham do laboratório, riscos, sujeiras horríveis, mudanças de cor, eram processos foto-químicos, primitivo. Só isso já é uma 
tremenda revolução, sem contar aquilo que, sabe, na prática diária a gente tem à disposição, que é muito mais ainda do que isso.

ML - O que o senhor acha que mudou na característica dos filmes, de meados dos anos 80 , quando os estúdios faziam 3, 4 filmes, para a época depois da computação? Sem querer ser saudosista, mas aqueles filmes tinham um certo charme, um encanto... hoje a estética da maioria dos filmes de computador parece meio banalizada...

DM - Eu acho o seguinte, que esse processo afeta os animadores veteranos, como eu, que somos um pouco tomados por esse saudosismo de certa maneira, mas isso não pode trair o fato real, a mudança de fato acontece, e é fatal... mas, tentando ver a coisa muito objetivamente, acho que isso é sazonal, essas mudanças sempre vão ocorrer. É uma coisa cíclica, a animação passou por um processo fundado no excesso do individualismo do autor, do artista, do animador. Isso implicava numa demanda de uma qualidade de desenho muito grande. Aqueles filmes traíam sempre a cara do animador.

Na década de 1980, eu vendo televisão, eu via cada comercial, eu sabia quem tinha feito, o animador que tinha feito, eu dizia: "esse é do Guy, esse é do Joaquim 3 Rios, esse é do Walbercy, esse é do Briquet, aquele é do Takeshi ", eu sabia exatamente dizer porque cada um tinha - claro que os meus eu tb sabia - eu sabia o estilo de todo mundo, era fácil vc identificar, então, havia estilos de animadores - mais do que estilos de animação, estilos de animadores. O que acontece, eu acho é que a demanda pela produção, pelo volume exigia um certo aniquilamento dessa personificação, quer dizer, a coisa começou a se massificar.

O preço que se pagou da qualidade da produção, da limpeza, da velocidade, foi esse, foi acabar com o individualismo, com o personalismo. Não havia mais lugar prá isso, assim como não há lugar prá saudosismo. Então, a coisa ficou, de certa maneira, muito formatada. É difícil hoje vc identificar personalismos, vc vê mais estilos, ao contrário de antes. Antes vc via o trabalho pessoal, hj vc vê o trabalho de estilos, mas estilo, pode ser 20 animadores fazendo a mesma coisa, diferentes animadores, diferentes produtoras. Porque o mercado hj exige produção. A multiplicaçnao de canais de TV a cabo, a internet, a web, tudo isso tá exigindo produção. Então, não há muito mais lugar prá aquele processo quase artesanal, que era dos nossos ancestrais. QUer dizer, isso já veio é um processo que vinha da década de 1914, 18, né, os primeiros filmes, quer dizer, um processo idêntico quase de animação. Então, iso foi mudando, claro, o computador ele deu uma sacolejada, apressou as mudanças, foi a primeira grande revolução. As outras foram cosméticas. Você coloca o acetato, você coloca um pino diferente, daquele engenheiro (ininteligível) que adotou os 3 pinos, mas continua sendo um sistema mais ou menos tradicional. QUando vc eliminou câmera, eliminou o sistema analógico por total, eu não tenho mais o filme, a película, é uma grande revolução. Quer dizer, tem que aceitar essa revolução, é fato, não pode ficar mais no saudosismo. Agora, eu acho que continua - e isso é bonito - a existir criadores que estão usando um sistema pessoal ainda de trabalho independente do computador, então, de uma forma ou de outra continua empregando o computador, mas emprega - o próprio Bill Plimpton que é um sijeito que consegue fazer essa fusão do processo mais ancestral de produção, que é o lápis com os sistemas de edição digital, de captura de imagem e de som também digitalmente. Eu acho que continuam ainda esses processos, quer dizer, a criação não vai ser aniquilada jamais. A individualidade do artista, isso vai continuar. Agora, as ferramentas vão mudando. e vão mudando cada vez mais. Você não anima hj mais numa prancheta, vc usa um Cintiq, que é um tablet, mas o profissional está atrás disso, não é um técnico em informática, é um artista; ele vai ser orientado como trabalhar com o software/hardware, mas atrás disso tem um criativo, tem um cara criador, fazendo criação. Eu acho que esse é o futuro das coisas. Esse é o futuro da arte da animação.

ML - Vocês ainda fazem filmes comerciais aqui?

DM - Como eu te falei, eu estou me dedicando exclusivamente à direção e à criação. Eu não quero ter mais equipe, eu indico a produtora, nesse caso, eu tenho uma parceria com a 
produtora do Nicolay, às vezes eu faço umas pequenas animações, uma cenazinha, ou outra, eu gosto de fazer prá não perder a mão. Mas animação mesmo, eu não tenho mais equipe. Mas isso foi uma opção. Eu não fiz isso traumatizado não. Fiz isso porque não há mais interesse em manter uma equipe em que eu tenho mais gasto do que não... hoje, como pequena empresa, vc vive prá pagar impostos, não tem como fugir disso, vc vive prá pagar salários, eu acho isso uma perspectiva muito ruim.

ML - Como o Plano Collor impactou a produtora?

DM - Eu acho que eu sempre me preparei psicologicamente pros grandes traumas, eu tenho que estar preparado para as coisas ruins com altivez. O Plano Collor foi uma coisa dessas. Quando ele surgiu, eu estava, primeiro, trabalhando muito; segundo, a rotatividade do dinheiro aqui era muito grande, os filmes entravam, a gente pagava e ficava a zero. Eu não tinha, como nunca consegui, nos últimos tempos, eu nunca consegui acumulação, quer dizer, reserva. Formar um capital de reserva, balela. O dinheiro entrava, saía. A gente tinha que manter a coisa funcionando através do trabalho.

Quando isso aconteceu, o Plano Collor, Prá mim, não estava mudando nada, porque eu não tinha nada no Banco, a gente estava pagando salário, e pensando: "se todo país está assim, alguma solução vai se dar" prá isso. Eu estou a zero hoje. Mas todo mundo está avisado de que eu não sou o culpado. Então, se houver um atraso aqui, e deve ter havido, de salário, todo mundo estava ciente de que alguém era responsável por isso, não era um problema da minha administração. Que eu sempre paguei pontualmente. Era um problema geral, nacional. Eu não perdi nada porque eu não tinha nada. Se eu tivesse, talvez hoje eu estaria amargurando aqui. Então, foi realmente um calote nacional, uma tragédia prá muita gente, um desastre em matéria de economia, mas eu não tenho assim, da época, a não ser a raiva... eu deveria até agradecer o Collor, porque eu acabei fazendo um curta-metragem "Dinda's", que acabou ganhando um prêmio em Cuba, não sei como, porque não fui eu quem mandei, foi o MIS. Eu estava querendo fazer um curta-metragem, eu tinha muito tempo ocioso, e de repente, quando eu ouço o Plano Collor, foi uma tragicomédia. Eu estava montado um armário enorme, cheio de livros, e estava com o rádio ligado e, de repente, notícia de última hora... 


\section{APÊNDICE D - Transcrição Entrevista CARVALHO}

Entrevistado: Guto Carvalho (GC)

Entrevistador: Maria Luiza Dias de Almeida Marques (ML)

Local: São Paulo- SP

Data: 12 de setembro de 2013

Duração da entrevista: 81 min

ML - Qual a sua formação, o que te levou a trabalhar com animação e quem te inspirou artisticamente?

GC - Minha formação tem algumas vertentes, vertentes de exatas, cursei física na Unicamp, durante 4 anos, não completei o curso, mas foi muito forte na minha formação essa vertente científica, digamos assim, cheguei a trabalhar em laboratório, desenvolvi projetos, pesquisas e tal, depois, fui atrás de uma vertente artística, trabalhei com teatro e dança um bom tempo, e finalmente, fui prá uma vertente humanística, trabalhando com pedagogia, e tecnologia da educação, de onde derivou a minha atuação profissional hoje, que eu considero que numa boa medida sou um educador, talvez, se eu fosse me definir, eu me defino como uma pessoa muito preocupada com a questão da educação, do conhecimento e da transmissão do conhecimento, e isso reflete-se também quando, na faculdade de educação, eu optei por fazer a minha pós graduação na área de TV educativa, que me levou à área de produção, ao cinema, finalmente, em São Paulo, isso, educação, eu estudei em Brasília, na Universidade de Brasília, e, de volta a SP, fio trabalhar com pós produção de cinema, cinema publicitário, e montei minha produtora, há 22 anos, em 1991, montei a produtora Trattoria, a gente atuava bastante na área de efeitos especiais e daí prá vir para animação foi um pulo, a gente acabou se firmando como uma produtora de animação.

As inspirações artísticas são variadas, eu, talvez já seja uma primeira geração em que as inspirações vieram multi-facetadas, digamos assim, eu acho que, numa primeira linha foi MTV, e as pessoas que produziam prá MTV, Pablo Fierro talvez, um dos nomes mais fortes que cunhou essa linguagem MTV de animação, lá nos anos 70, 80, e que veio a ser reproduzida pela MTV... sempre gostei de animação experimental, não gosto de contar histórias, até acho legal histórias, mas a minha produção em animação sempre foi mais, a produção autoral, digo, foi mais ligada ao movimento em si, o que até, numa boa medida eu vou reconectar com a questão da ciência lá atrás, de entender os movimentos, e hoje tá muito voltada a uma questão da relação com a natureza, ou seja, entender como a natureza, os fluxos do tempo, essencialmente, usar a animação como uma lente temporal, digamos assim. E nesse sentido, uma grande influência, talvez uma das maiores influências na área de animação, pro meu trabalho pessoal, foi um animador dinamarquês Leif Marcussen, um cara extremamente experimental, que animava pedras, um cara que me ensinou que animação é essencialmente musical, que a gente não deve permitir que os dramas e as histórias e a febre emotiva dos humanos se intrometa na questão temporal da animação, impondo histórias, impondo dramas. Dramas e histórias são da ordem de outras artes.

Animação é a arte do movimento, é a arte do tempo. Não está ligada a contar histórias. Por outro lado, no meu trabalho especificamente, porque eu divido a questão autoral e a questão profissional, porque boa parte do meu trabalho com animação foi no âmbito da publicidade, onde somos praticantes de arte, mas de arte marcial, digamos assim, quando a gente tem que resolver problemas e criar soluções, e aí tem toda uma linha de trabalhos que tiveram sim uma repercussão grande, pela MTV, mas que são de autores... como trabalhei muito com stop-motion, é inevitável que Aardman Studio surja como uma referência muito forte, então, várias coisas que eu fiz foram claramente inspiradas na Aardman Studio, e com uma série de autores que utilizavam técnicas experimentais, como recorte, animação figuras recortadas, e stop-motion posterior, misturando, dentro de uma linha multi-técnica, sempre... talvez o caráter mais forte tenha sido o lado multitécnica, dos trabalhos que eu fiz.

ML - Essa característica vc propunha às agências ou elas te procuravam porque achavam 
que vc tinha esse perfil?

GC - Na relação profissional com as agências, a gente pode colocar 2 tempos muito distintos, que têm a ver tb com o prazer em realizar o trabalho e mesmo com a decisão de deixar a animação na publicidade. No início a troca era muito intensa, vc podia propor muito, trazia muitas referências, as agências e os clientes contavam com o nosso trabalho como um arsenal de soluções técnicas, e principalmente nos anos 90 , os 10 primeiros anos da atuação, digamos assim, foi muito bom esse diálogo que havia, a gente podia sempe oferecer técnicas, oferecer soluções, ou então pegava dentro de um contexto, havia um espaço para experimentação bastante grande, até porque a nossa produtora, especificamente era conhecida por isso, por ter um repertório técnico bastante grande, e de encontrar soluções e propostas visuais diferenciadas, prá vários projetos.

Naquela época, as outras produtoras de animação, eram bastante consagradas, digamos assim, nas suas técnicas, e tinham seus nichos técnicos bastante definidos, normalmente ligados ao estilo de trabalho dos seus líderes, dos proprietários, dos artistas mestres, né? Havia também a Vetor Zero, que também era muito caracterizada por soluções 3D; e a Trattoria ocupava um nicho intermediário, que não era nem animação clássica dos estúdios como a Start, como 3 Rios, vários outros, o Daniel Messias, nem era a 3D incipiente, mas muito bem feito que a vetor proporcionava. A Trattoria oferecia uma animação multi-técnica, e conseguiu ter soluções e propostas diferentes prá cada filme, cada projeto.

ML - Vc estava dizendo que são 2 tempos diferentes: o primeiro, em que o diálogo era bem forte. Num segundo momento, como foi?

GC - Num segundo momento, ligado diretamente, deixa voltar um pouquinho, num primeiro momento, a gente investia muito em pesquisa de técnicas, participação em festivais, conhecimento de novos profissionais, novas pessoas, novos modos fe fazer, investia-se muito nisso, a gente ia anualmente ao festival de Annecy, participava, conhecia, via novos filmes. Com o aumento da internet, a popularização e a distribuição dos filmes, essa questão da referência passou a ser de menor importância, muitas vezes aí a agência já fazia suas próprias pesquisas e vinha com seus próprios indicativos de solução, o que sempre foi bastante interessante, mas prá mim especialmente, teve um retrocesso, digamos assim, porque você muitas vezes era obrigado a lidar com uma técnica que não era exatamente a mais adequada ao filme, ou não tinha muito a ver com a linguagem, ou se tornava meramente tentar reproduzir uma determinada solução, e nesses tempos, era muito engraçado, porque vc via claramente como um determinado efeito visual, como ele surgia inicialmente enquanto pesquisa num curta-metragem, lá no festival de Annecy, que quase ninguém via o filme, tempos depois, ele aparecia, novamente o mesmo efeito num clipe de uma banda obscura, de não sei o quê, feito por um artista experimental que tinha ido lá no Festival de Annecy, aí, tinha mais repercussão, num terceiro momento, ele era visto num clipe de uma banda mais mais rica, mais endinheirada, com uma melhor produção, depois, num quarto momento, ele estourava e bombava num filme de Hollywood. E num quinto momento, ele era utilizado como uma novidade por uma agência de publicidade brasileira que cria uma solução visual, uma referência visual pro seu comercial, até que ele ia prá TV banalizado como um comercial; era muito engraçado ver; isso aconteceu com vários tipos de efeito e...

Porque essa época também é uma época muito rica em que o uso dos computadores começou a incorporar uma série incrivelmente diversificada de recursos visuais à produção audiovisual. Coisa que não havia antes. Então, foram muitos os efeitos, havia até uma certa moda de efeitos; eu me lembro quando surgiu o efeito Matrix, por exemplo, do time slice ou time bullet, que seguiu exatamente essa trajetória que eu descrevi aí atrás, de ter sido feito num curta, chamado Temps Morts, lá em 1995, depois foi num clipe de uma bandinha, depois no clipe dos Rolling Stones, depois no filme Matrix. E depois, na publicidade brasileira. 
Então, foi essencialmente uma época muito rica. QUando a gente começou, toda a produção era em película, em filme, correção de cor, tudo isso era um processo muito... depois veio prá fita magnética, BetaCam, 1', finalmente prá fitas digitais, como D1, D2, e finalmente prá workstation, dentro de disco, espaço onde está até hoje, e que tem permitido uma revolução, na produção audiovisual.

Outra característica é que na plataforma digital, técnicas que eram completamente distintas, como a técnica de live-action, e a técnica de animação, que tinham, embora, uma origem comum lá atrás, andava muito distantes. O workflow, o modelo de produção de animação não tinha a ver com o modelo de produção de live action; e quando o computador surge como plataforma unificadora, onde esses dois universos totalmente distantes tecnicamente passaram a conviver, e criaram uma nova relação muito forte. Isso sem contar a evolução da própria computação gráfica, seja como animação, seja como reprodução da realidade, simulação, também, teve um papel muito importante na revolução audiovisual que a gente está vivendo.

ML - Como foi a primeira composição da empresa em termos de equipamento e pessoal?

GC - A gente sempre foi totalmente baseado em computadores. A Trattoria sempre foi desde o início baseada em computadores. Eu costumava dizer que a Trattoria era uma Quicktime-based studio. Ou seja, a gente surge junto com o Quicktime, que é essa plataforma de produção de filmes em ambientes computacionais.

ML - Vcs lembram quantos computadores vcs tinham, quais eram e quais os softwares?

GC - Sim, com certeza. Não sei se é relevante aqui, mas eu vou contar uma história: eu trabalhava como funcionário numa finalizadora, a New Vision. Era uma finalizadora que existia no Belenzinho, e que fazia a transposição entre o cinema e o vídeo. A New vision foi uma das primeiras finalizadoras que se preocupou em fazer de maneira bem feita a transcrição de toda produção publicitária que era feita em película prá vídeo. Então tinha um telecine, tinha um trabalho de correção de cor muito forte, tinha tudo isso; dentro do trabalho com a New Vision, a gente teve contato com todo o cinema publicitário brasileiro, com os grandes fotógrafos, os grandes produtores, os grandes picaretas, todo o universo da publicidade brasileira passava, mais cedo ou mais tarde, pelas salas da New Vision. Era uma empresa com um padrão técnico muito rigoroso, o Alex que era o diretor técnico era muito cuidadoso, e a gente teve a oportunidade de participar da digitalização da produção da New Vision, da finalização.

Eu era um dos finalizadores da casa, e participei ativamente da escolha da plataforma digital que foi instalada na New Vision prá sair da finalização em Betacam; a gente partiu prá finalização totalmente digital numa workstation que custava US $\$ 400,000.00$, na época. As estações de trabalho digitais eram da ordem de US $\$ 700,000.00$, US $\$ 400,000.00$, eram muito caras.

No processo de escolha da primeira estação digital, que era baseada numa arquitetura Windows, a gente teve contato com outro produto do mesmo fabricante que se utilizava da plataforma Maclntosh. Talvez tenha sido um dos primeiros produtos em vídeo pra Maclntosh. Nesse contato, surgiu a oportunidade de ... eu conheci a máquina, no tempo que eu fiquei nos EUA, trabalhei durante uns 4 meses com essa máquina, que se chamava D- effects, Digital -Effects, era um editor, basicamente uma suíte de edição que controlava os VTs mas fazia o processamento frame a frame das imagens, em ambiente digital, não fazia real time, fazia frame a frame, mas que permitia que vc trabalhasse as imagens em ambiente digital. (21:48)

Tempos depois, este foi o primeiro computador que a gente teve, foi um Mac Intosh, e duas unidades de disco que tinham na época algo como $400 \mathrm{MB}$ e era super, enorme, a gente não conseguia encher o disco de jeito nenhum. Não me lembro o modelo dele. (22:52)

ML - Esse Digital-Effects era um software ou uma ... 
GC - era uma plataforma, uma mistura de um software com algumas placas de vídeo dedicadas. Era mais ou menos na mesma época em que surgiu o topas, e havia uma placa que era muito conhecida que era a Targa. A Targa era uma placa de vídeo dedicada à computação gráfica, com ela, vc podia rodar 2 softwares que foram muito marcantes na época, que eram o TOPAS e o "Heeo" (não se lembrava do nome). O Topas, que era um software de animação 3D, um dos primeiros softwares de animação 3D. Mas a gente não optou pela plataforma Windows, todos estes eram plataforma Windows, a gente optou pela plataforma Mac Intosh, e o primeiro software que a gente pode dizer de animação fio o After Effects.

ML - Isso foi uma aposta ousada, vc pensar em adquirir... a Apple era um pouco incipiente... ela já tinha passado por aquela baixa e já tinha subido, ou...

GC - Não, ainda não tinha nem subido da primeira vez. Quando a gente optou pelo Mac Intosh foram os primeiros Mac Intosh que havia.

ML - Vocês se sentiram mais confortáveis no ambiente MAC, aquela coisa da beleza...

GC - Não, não, basicamente questão de custo. O Quicktime oferecia uma solução de processamento de vídeo a $1 \%$ do custo dos outros sistemas, ou seja, a mesma empresa que fez o Digital- Effects, que era uma solução "high-ending", eu acho que esta talvez seja o principal aporte tecnológico e o principal investimento que a Trattoria fez e razão até determinante no sucesso tecnológico da empresa, a Trattoria sempre foi uma empresa com viés tecnológico, muito forte, de ter um custo muito efetivo, de ser um custo muito bom para resultados que, antes só eram possíveis em estações de US\$400,000.00. (25:46)

A gente conseguia fazer com um Mac relativamente barato, na época a estação não custava, custava pouquíssimo, comparado, custava US $\$ 4.000,00$, US $\$ 3.000,00$, conseguia fazer os mesmos efeitos que uma estação de US\$ 400.000,00. A diferença era o tempo de processamento. A de US\$ $400.000,00$ fazia em real time e a fe US $\$ 4.000,00$ fazia frameby-frame. Mas, se vc conseguia gerenciar o tempo, você conseguia... então, logo em seguida, a gente usou o processamento distribuído, ou seja, tinham várias máquinas pequenas, conseguindo fazer o trabalho de uma máquina gigantesca que... o que deu prá gente, a nossa empresa não era uma empresa... não tinha um investidor, ninguem no $B R$ tem um investidor praticamente, não é, a gente não era uma empresa de capital intenso, pelo contrário, era uma start-up - e, nesse sentido, a Trattoria tem todas as características das start-ups atuais, ela era uma empresa baseada em inovação, baseada em soluções, isso há 20 anos atrás - pausa para o café...

ML - Esses equipamentos que vcs adquiriram para a Trattoria, foram um pouco no modelo da New Vision, que vc viu e aprendeu e estudou lá, vc trouxe aquilo pro tamanho que iria caber financeiramente na Trattoria, pode-se dizer assim?

GC - Sim, mas tem uma questão muito importante que é: a New Vision preferiu ficar com os mainframes, preferiu ficar com as máquinas grandes, enquanto que a gente, imediatamente quando viu uma oportunidade Mac Intosh, baseada em máquinas pequenas, a gente optou por isso; inclusive, o primeiro computador que a gente teve, que rodava em sistema de digital effects, ocorreu exatamente o seguinte: eu tinha passado um tempo em NY fazendo um treinamento para a estação mainframe da New Vision - a New VIsion havia comprado uma estação mainframe, centenas de milhares de dólares, e eu passei um tempo fazendo um treino prá esse equipamento em NY. Lá em NY, eu comheci um sistema pequeno, baseado em MAC Intosh, numa época em que a adobe era uma start-up. Não existia, o photoshop era uma promessa. O After effects era uma promessa.

Nesse tempo, eu conheci esta estação pequena, e havia gostado muito. Meses depois, de volta ao Brasil e trabalhando na workstation da New Vision, um belo dia, vem o 
Alex, que era o dono da New Vision, ele me chama na sala dele e fala assim: "olha, Guto, surgui essa pessoa aqui, que era um cara de uma empresa chamada Multi Soluções...", nesse tempo, o Mac Intosh já havia dominado o universo gráfico de impressoras e...

ML - Em que ano isso?

GC - Isso é bem anos 90, fim de 1991. Quando ele falou assim: "eu sei que vc estudou esse sistema Mac Intosh, tá aqui esse rapaz que apareceu aqui, ele comprou uma máquina dessas e não sabe o que fazer. Ele veio perguntar se eu quero, eu falei 'não quero, pq esse aí não serve prá mim' mas eu acho que pode ser que sirva prá você." Eu falei: "serve mesmo". Disso aí surgiu a Trattoria. Dessa oportunidade desse cara que havia trazido uma máquina que ele tinha visto, que era um mac Intosh, mas que ele não sabia prá que era que funcionava, não sabia usar a máquina, e eu sabia usar e a gente lançou essa idéia e montou uma produtora baseada neste primeiro Mac Intosh. Então, em relação... a gente sim reproduzia o ambiente da New Vision, reproduzia um ambiente hi-tec, mas na escala pessoal, com computador pessoal, não com um computador... e fomos sim ousados em afirmar com certeza que a gente conseguiria fazer efeitos e soluções gráficas muito interessantes num computador pessoal coisas que só eram possíveis em estações muito caras.

Eu me lembro de um dos primeiros jobs da Trattoria que um cliente queria fazer um efeito na New Vision e não conseguia fazer de jeito nenhum e que a gente sabia que podia fazer no Mac Intosh e ofereceu prá ele o Maclntosh, e fez e foi um sucesso. Foi um filme de Marlboro, na época tinha comercial de cigarro.

ML - Quem era a agência? Essa primeira trattoria, quem era?

GC - Leo Burnett. A Trattoria era eu e o Guilherme Ramalho.

ML - E o cara da Multi Soluções não quis ficar com o computador?

GC - Não, o cara da Multi Soluções, ele era um cara muito estabelecido no ramo de Desktop Printing, ele trabalhava com... mas ele foi muito importante na história da Trattoria, porque a gente fez um acordo onde conseguiu, como ele não sabia bem o que fazer com o equipamento, a gente fez um acordo que foi muito favorável prá gente, de comprar o equipamento e usar o equipamento a um preço muito simbólico praticamente, mas ceder o uso do equipamento como show room; então foi uma joint venture, uma simbiose. Mas foi muito engraçado, porque ele tinha uma coisa que eu não conhecia o poder ainda, mas ele tinha uma acessoria de imprensa muito forte da área de Desktop Printing. Quando a gente começou a trabalhar e lançou a Trattoria, no mesmo dia ele fez uma acessoria de imprensa muito forte, não da Trattoria, mas do Show room, da possibilidade de... e foi muito engraçado, porque a gente alugou uma sala junto com o Humberto, montador histórico da publicidade brasileira, uma lenda viva da publicidade brasileira, e montamos a Trattoria, dividimos uma casa com eles, e no dia que a gente estava praticamente começando, a acessoria de imprensa conseguiu uma mega-matéria, na folha llustrada, onde colocava o telefone da Trattoria, e aí, tinha umas 400 pessoas ligando no mesmo dia e o pobre do montador enlouqueceu com seus parceiros hi-tec.

ML - Ele era montador de moviola?

GC - de moviola, ele montava na moviola; na mesma casa tinha... era o primeiro sistema, que era um pré-avid. Era um primeiro sistema de edição não linear. Ele trabalhava da seguinte maneira: ele controlava uns VTs e fazia uns proxies, eles capturavam uns quicktimes pequenininhos, aí, você editava nos quicktimes pequenininhos, e depois mandava o VT fazer aquela edição. Ele era um misto de um sistema não- linear, mas o resultado final era feito numa máquina linear. O que é genial, porque permitia ah... e, além 
disso, com a máquina linear ele fazia as partes que tinham efeitos sofisticados, ele procesava esses efeitos e descarregava frame-a frame; então, era uma máquina muito legal.

ML - Conte um pouco como foi a história com o Washington Olivetto...

GC - Isso do Washinton Olivetto vai chegar agora, porque, um dos resultados inesperados dessa acessoria de imprensa e de sair a matéria na folha de São Paulo, foi que a gente recebeu uma série de demandas que caíram de pára-quedas, algumas desparatadas, e outras, muito interessantes. No início a Trattoria se posicionou como um bureau, de desktop vídeo, bem na linha do que era um bureau gráfico. Nesse sentido, a Trattoria surge um pouco estruturada com esse know-how do cara de desktop graphics. Porque na época o mac Intosh era a máquina de desktop graphics. Não existia desktop vídeo. Então, a primeira solução em desktop vídeo que surgiu no Brasil foi a Trattoria.

E daí, tempos depois, uns 6 meses depois, o Guilherme pegou um frila prá fazer em Portugal, fora da produtora, eu tinha montado uma produtora e o meu sócio saiu prá ir fazer um frila de 4 meses em Portugal. Logo no início; a gente lançou a Trattoria em agosto, final de agosto de 1991, e ele ficou de agosto a dezembro fora. Em dezembro, próximo ao Natal, um belo dia me liga alguém da W/Brasil. Um produtor gráfico da W/Brasil, falando "tem uns negócios de desktop vídeo, tem umas coisas aqui, vocês não querem... acho que vcs conseguem fazer prá gente."Eu falei: "o que que é?". " Conversa com o nosso diretor de arte que ele sabe. Passa o [telefone] Jarbas Agnelli, que era um garotão na época, como a gente, falando "oh, putz, eu tô com um problema aqui que eu estou tentando resolver e eu não consigo... tem umas coisas que eu fiz no illustrator e eu queria passar prá vídeo..." eu disse "você não consegue transformar isso aí prá pict?" "Posso". "Então, traz aqui que a gente consegue passar prá vídeo e fazer filme". "Jura?" eu falei "Sim, pode trazer que a gente faz". Aí ele trouxe, e era uma animaçãozinha que ele havia feito no ilustrator, o Jarbas - vc devia entrevistar o Jarbas, o Jarbas é muito importante nesses tempos, ele foi o cara de agência que viu isso, e ele sempre foi um cara tremendamente inovador. $E$, na verdade, o Washingon era apaixonado pelo Jarbas, que era apaixonado pela Trattoria. É mais ou menos este o caso de amor.

Resultado: ele trouxe uma animação que ele havia feito e que a gente acabou de animar, de montar e botou em vídeo, e era uma animação para um festival em Cannes e ganhou o terceiro lugar em Cannes, um Leão de Bronze, logo nos 6 meses da produtora. Isso deu uma tremenda visibilidade prá produtora, logo nos seus primeiros meses de vida.

ML - vc tem esse filme?

GC - é Olla,

ML - sabão em pó?

GC - não, camisinha, que era um monte de espermatozóide que vinha... [cantarola a cavalaria rusticana], e é muito engraçado porque junto com isso, surgiu tb a possibilidade de uma pessoa que não era propriamente um animador, mas que tinha conhecimentos de animação, mas que tinha um skill gráfico muito forte, o Jarbas sempre foi um desenhista muito bom, de usar as ferramentas de desktop printing que já estavam bastante avançadas o printing já tinha avançado bastante em relação ao video - e começar a fazer coisas de desktop printing, transferir esta tecnologia do printing para o vídeo. E o Macintosh, de novo, foi a plataforma ideal prá fazer isto. (45:53), E a Trattoria tinha os conhecimentos de linguagem e tudo, para catalisar esta revolução. Então, este filme, do ponto de vista do mérito artístico, ele é inteiro do Jarbas, a gente fez só coisas... eh... mas ele foi muito marcante e determinou o surgimento de um novo tipo de filmes no mercado do cinema de animação. Era um filme totalmente digital, este filme não tinha sido papel nunca na vida. $E$ também não era 3D. QUe aí, eu acho que tem toda uma linha de produção onde eu acho que a Trattoria foi muito bem, que era de filmes que não eram de origem de animação 2D 
clássica, não era o 3D, que já tinha a sua linguagem, mas eram filmes experimentais feitos em Macintosh, né..

Disso aí, veio uma relação de muitos anos com a W/ Brasil, e logo em seguida, nesse tempo tb, a DM-9 estava se... o Nizan tava se desligando da W/Brasil e fundando a DM-9 e tb tivemos uma relação de longo tempo com a DM-9, e tb uma outra relação de longo tempo que foi interessante foi com a Marisa Monte. Nós fizemos alguns trabalhos, como algumas lendas vivas, como o filme "Diariamente".

ML - Quem orçava os filmes nessa época?

GC - Eu, eu sempre cuidei dos orçamentos, no início da Trattoria até mais ou menos metade da vida, os primeiros 6,7 anos da trattoria, tanto eu quanto o Guilherme, a gente fazia tudo da produtora, todos os orçamentos...

ML - Qual era a base do cálculo?

GC - Era assim: a gente sabia que a gente operava com um custo que era infinitamente menor do que o dos concorrentes, então, poderia trabalhar com uma margem de lucro bastante grande, porque a gente oferecia uma solução tecnológica bastante diferenciada, e praticamente ninguém mais oferecia isso. Então, a gente tinha uma grande possibilidade de realizar, era bastante rentável o negócio. Mas a gente sempre reinvestia muito. Então, como a gente não tinha um capital externo, tudo era reinvestido na própria empresa e tb nos próprios filmes, os filmes da Trattoria sempre tinham over-quality, eles tinham investimento em qualidade muito grande em relação ao seu custo e à própria demanda.

ML - A distribuição da verba ficava: um pouco para vcs, um pouco reinvestia nos filmes, e um pouco para as despesas da produtora?

GC - A trattoria, quando surgiu, foi extremamente inovadora em vários aspectos, e foi forçada, ou acabou optando por isso, a se formalizar e se tornar uma empresa menos inovadora. Isso é engraçado. Porque, quando a Trattoria surgiu, ela operava como um coletivo. Essas coisas de horizontalidade, co-criação, que hj são ditas como bastante inovadoras, e revolucionárias e tal, a gente fazia isso nos anos 90 . A essa proposta inovadora da TRattoria do ponto de vista tecnológico, somou-se uma gestão totalmente inovadora; embora eu e o Guilherme cuidássemos dos orçamentos, tinha uma série de artistas e agregados, que, na época, era desde o Rui Amaral, o Carlos Freitas, o Tom, o Suannes, a Ciça, eram pessoas que trabalhavam mais ou menos como um coletivo. então, boa parte da distribuição, gastava-se muito com, boa parte da grana era pra turma que trabalhava. A integração era tanta, que alguns tinham pretenções ou vontade se ser sócios da produtora, mas, por demanda do mercado publicitário, que não sabia dialogar com coletivos, só sabia dialogar com estrelas, a gente foi forçado a centrar o foco e centrar em uma ou duas pessoas, no caso, eu e o Guilherme, como os diretores da casa e fazer se adequar ao modelo publicitário. O que numa boa medida foi determinante pra história da produtora, até mais pra frente, quando surge... assim, a Trattoria tinha tudo pra ter sido um tremendo caso de sucesso também na internet. A gente já fazia internet, fazia de maneira criativa antes de todo mundo, mas, nesse caso, como a gente gostava de fazer filmes, a gente optou por ficar fazendo filmes, e não surfar a onda da internet, mas isso são escolhas, e, que eram muito marcadas por esse modelo de coletivo de fazer as coisas né?

Então, boa parte da grana era reinvestida em equipamento, às vezes a gente pegava um trabalho e dizia assim: "esse trabalho vai pagar um computador novo. Esse trabalho vai dar de lucro uma impressora boa, esse trabalho vai dar de lucro uma Beta-Cam...eram os critérios de orçamento. Como a gente não tinha capital de investimento, era tudo reinvestido. Não me lembro das proporções, mas era bastante alto a percentagem destinada aos talentos, às pessoas que trabalhavam com a gente, que eram várias. TInha um momento em que havia de 10 a 15 artistas assim... envolvidos no trabalho. 
ML - Eram freelas?

GC - Não, era uma coisa meio simbiótica, não era frila, porque era uma turma que era assim um coletivo, que é um pouco diferente que um coletivo, carteira assinada, a gente nunca teve. O modelo de produção CLT não se aplica a negócios tecnológicos, isso é uma questão de legislação trabalhista mal formulada.

GC - Quem fazia o Lay-out artístico/ Story-Board, decupagem, sincronismo com o som?

GC - dentro da linha de produção da publicidade, sempre coube ao diretor fazer estas propostas. A gente pode distinguir dois momentos na vida da Trattoria: um, quando era mais coletivo, quando se sentava num grupo e todo mundo fazia um "toró de parpite" todo mundo dava suas ideias, sugestões, selecionávamos umas tantas e chegávamos numa proposta coletiva que era apresentada pelo diretor. Dez anos depois, a coisa se formalizou muito mais, e um diretor ia pra agência, pegava o brieffing, voltava e trabalhava com um diretor de arte pra chegar nas propostas. Nesse momento, tinha, por exemplo, um profissional de pesquisa, fazia pesquisas de referência, baseado no brieffing do diretor, ele corria e pegava muitos filmes pra alimentar o processo de construção estética do filme, e, a partir daí, definia-se um look, e apresentava uma ou duas alternativas à agência, que tb dava os seus inputs, e definia-se junto, fechava-se por uma opção.

Então, nessa segunda etapa mais formalizada, a questão do story-board, a gente sempre trabalhava com um profissional de story-board, que tabalhava junto com o diretor dando forma visual pras ideias que o diretor ia colocando. Fazendo propostas de quadros, sugestões.

\section{ML- Vcs faziam animatic?}

GC - Sempre, desde sempre. A gente sempre acreditou que... isso vem de uma cultura da trattoria, que tb sempre esteve ligada a produção de software, a trattoria teve uma etapa de produzir muita multi-media, e tinha uma linha de produção muito ligada a software, onde a importância das versões beta, vc sabe que vc faz uma versõa que não é funcional, então, os nossos filmes, eles sempre, o objetivo era completar o filme, fazer várias versões do filme. A gente até fazia uma coisa que a gente chamava de bloco-board, prévio ao animatic, era mais ou menos uma divisão por blocos no filme, o fato de sempre fazer publicidade, trabalhar com duração fixa, e muito curta, isso ajudou muito, isso objetiva muito a realização. Depois fazia um animatic, depois fazia um lay-out de animação, depois um lay-out semifinalizado. De um modo geral a gente apresentava o animatic na reunião de produção. porque a gente sempre teve como política, trabalhar da maneira mais pública possível. $O$ seja, as decisões a respeito do filme eram tomadas ao longo do processo pra evitar surpresas de última hora. Tudo era muito pactuado, combinado, discutido exaustivamente, pra que ao final não tivesse surpresas.

ML - Quem cuidava da parte de som?

GC - Normalmente, a parte de som ficava com uma produtora de som externa. A linha de produção na publicidade sempre contou com uma produtora de som externa, que era parceira nossa, e que muitas vezes era indicada pela agência porque fazia tb a produção do rádio. Então, um filme de publicidade era uma peça dentro de uma campanha multi-media que incluía rádio, jornal, revista, e tv, ou seja, a peça de TV tinha que estar alinhada com as oitras mídias, e no caso específico do som, era muito claro este alinhamento porque a produtora pensada pra fazer o rádio fazia tb a trilha do filme de TV.

ML - vcs tiveram em algum momento animadores trabalhando fixo ou vcs sempre chamavam os colaboradores? 
GC - Sim, tivemos animadores trabalhando fixo numa época, chegamos a ter várias pessoas, contratados CLT.

ML -Em que mídia os filmes eram entregues?

GC - Eram entregues sempre em Betacam. Analógica. Embora a gente trabalhasse com finalização analógica e digital, durante toda hustória da Trattoria a entrega em Beta analógica sempre foi o padrão. Betacam SP analógica.

ML - quando ouviu falar pela primeira vez em computadores para animação? Como adquiriram o conhecimento específico para trabalar com os softwares? Faziam os tutoriais, manuais?

GC - A gente tinha e mantinha durante muito tempo um departamento de pesquisa. Um dos sócios no início, logo que eu me associei com o Guilherme, logo em seguida entrou o Freitas, que era uma pessoa de pesquisa. Sempre foi um pesquisador. E ele trouxe muito esse modelo de trabalho, de vc pegar um software e deschavar. Lendo o manual, inventando, experimentando, era muito gostoso este processo. A Trattoria sempre foi baseada em conhecimento, em desenvolvimento. Era a maior alegria, quando chegava um equipamento novo, a gente passava horas lendo o manual, brincando e descobrindo coisas novas.

ML - quem lidava mesmo, "mão na massa" eram vc e o Gui?

GC - Logo no começo sim, mas logo em seguida veio o Tom... Foi uma rede... foi muito importante uma conexão com a MTV, que foi um espaço de experimentação importante que havia. Não pode dissociar a trajetória da Trattoria da da história da MTV, não que fosse nada formal, mas muitas pessoas que eram da MTV vinham pra Trattoria porque tinha um espaço pra experimentação. Era um tempo de muita experimentação, os anos iniciais da Trattoria.

ML - A questão do Collor, como os afetou?

GC - Como a gente não tinha dinheiro, a questão do Collor não nos afetou muito porque a gente não tinha capital, não tinha dinheiro na poupança, nesse sentido, não afetou muito e foi indiferente. Mas, nessa linha de conjunturas externas, pelo contrário, a gente viu que logo em seguida do COllor, veio o FHC como ministro da economia, planejamento, sei lá, e que trouxe o plano real. Então, sim, o plano Real foi fundamental, porque quando a gente fazia os orçamentos, tinha que lidar com uma inflação estúpida. Era uma inflação de $20 \%$ ao mês. Então, o orçamento tinha que prever isso, era uma manobra financeira muito grande. Eu me lembro claramente do alívio que foi quando estabilizou a questão da coisa e a gente podia fazer orçamentos mais realistas, e mais fáceis de serem seguidos. Isso foi, pra gente, que estava começando, um ambiente miuto propício pro desenvolvimento econômico. O Plano Real foi logo no segundo ou terceiro ano da Trattoria. Eu me lembro que a gente pensou "nossa, agora eu posso finalmente planejar e cumprir um orçamento" sem o componente inflacionário, que é terrível pra gente, né.

ML - quem trazia os equipamentos pra vocês?

GC - Ah, sim, tinha um muambeiro oficial, com certeza. Não havia nenhuma produtora que sobrevivesse sem o seu executivo de fronteira.

Finalizando... 
GC - Foram anos excitantes, de 90 até hoje, veja bem... tanto e quanto o Guilherme e a maior parte das pessoas que se juntou à gente na trattoria, tinha um perfil de descobrimento, de desenvolvimento muito grande. A Trattoria, eu lembro que eu definia ela como uma quicktime based company, isso é muito louco né, havia uma plataforma que possibilitou, um modelo de produção de vídeo que foi possível dentro do computador, QUE, NA VERDADE, NA ÉPOCA, O QUICKTIME não era pensado só como um modelo de produção de vídeo, mas sim, como uma plataforma pra informação sobre tempo, que é um pouco mais sofisticado do que vídeo, animação, tal. Foi de fato muito excitante ter vivido todo este processo. Principalmente ter começado a... eu nunca de fato lidei, embora tenha sido assistente de montador em moviola durante um tempo, pouco tempo, 6 meses, a gente teve essa vivência com o pessoal de cinema muito forte, desde os tempos da New Vision. $E$ conseguiu entender este universo, tanto eu, como o Guilherme, éramos finalizadores, e entender este universo do cinema e entender como a lógica dos computadores subverteu isso. $\mathrm{E}$ fazer uma opção desde sempre por esta lógica dos computadores, mas ali na frente a gente voltou a recuperar valores do cinema. Então, a gente filmava em película, produzia em película... pode parecer meio petulância, pretenção, mas,1992, a gente tinha uma câmera digital, a primeira do Brasil veio parar na Trattoria, A Kodak tinha uma câmera digital. A gente queria fazer um filme, a gente foi lá e pediu emprestado a câmera da Kodak, que era a primeira câmera digital que tinha no Brasil. Não a primeira assim, veja bem, tecnologia, os milicos já tinham... a medicina também, mas a primeira voltada pra área de comunicação.

Tem outra coisa aí que eu acho importante, foi esse aprendizado de que a indústria da comunicação usa o equipamento de imagem muitas vezes, essa revolução dos computadores inverteu um pouco a lógica de desenvolvimento, por exemplo, a imagem médica trabalha hj com soluções gráficas e de imagem muitas vezes muito mais sofisticada do que a imagem de comunicação. Afinal, salvar vidas é mais importante do que fazer filmes. Se vc for ver por exemplo a tecnologia dessas coisas de ressonância magnética, isso é infinitamente mais avançado do que uma câmera de cinema.

A gente fez com uma câmera [fotográfica] digital o primeiro filme em stop motion digital, em 1992. Era um filme de Credicard, com a W/Brasil, umas animçõezinhas. Ninguém tinha.. talvez um dos primeiros stop-motion digital do mundo... porque não existiam câmeras digitais, e a maior parte das câmeras digitais não estavam com animadores.

ML - Era um tempo em que não se acreditava que o vídeo chegaria à qualidade do cinema...

GC - E a gente pelo contrário, a gente ia experimentando, e usava softwares, como por exemplo o after effects, são intrinsecamente ligados à história da trattoria e a esta revolução.

Não existia câmera de vídeo digital na época, era câmera fotográfica: batia a foto e descarregava no computador.

ML - vcs deviam ter um certo prestígio pra conseguir a câmera emprestada... levaram o portfolio?

GC - na época, a gente nem tinha portfolio, a gente era um bando de loucos, só que os caras tb não sabiam o que fazer com a câmera digital deles, porque ela era muito ruim pra fazer foto pra jornal. Eles trouxeram pra fazer foto de jornal, o pessoal do jornal viu e "não quero isso" ... Da mesma forma que o equipamento de vídeo o cara trouxe pra fazer desktopvideo e todo mundo torceu o nariz, isso não serve pra nada, e a gente soube ver nisso uma oportunidade, tb no caso da câmera digital que a Kodak trouxe pra foto jornalismo e ninguém quis saber disso pra fotojornalismo porque era péssima a qualidade... agora, pra fazer um filme, que tem resolução $640 \times 480$, na época, isso era muito boa essa resolução, era o padrão broad-casting na época. Era mais do que suficiente, então, a gente batia a foto, uma a uma e fazia uma animação, um stop-motion. Isso num tempo em que fazer stopmotion era uma loucura. Ninguém fazia stop-motion porque era muito complexo. Foi antes 
do COster fazer o filme dele. Tempos depois a gente concluiu que uma câmera de cinema fazia isso muito bem de uma maneira bem barata, ficamos com a câmera de cinema fazendo isso durante um tempo, mas logo depois pegamos também... trabalhávamos com uma câmera de cinema junto com uma câmera digital. O filme, por exemplo, do Super Pollo, um filme porterior, né, a gente trabalhou com corte, no mesmo filme, de câmera digital prá câmera de cinema: o Super Pollo tinha uma câmera de cinema - porque o cliente não queria câmera digital - eu falei "ah, tá bom". Eu botei a câmera de cinema e pus a câmera digital, as duas. Aí, eu rodei o filme em stop-motion com duas câmeras. Um luxo, né? Batia uma, batia outra, pra mesma animação, tinha o dobro de material, podia cortar... aí, comecei a cortar de um pro outro e eu mostrei pra ele: "então diz aí: qual que é o digital, qual é o analógico, e ele não...

Então, Malu, foi muito excitantante, do ponto de vista de aprendizado, de construção de conhecimento, e eu acho que isso talvez tenha sido umad das caacterísticas mais marcantes da trattoria, que deixa um legado, digamos assim, pras outras produtoras, e pra toda uma geração que se formou lá dentro, que é um pouco essa perspectiva de experimentar, de fazer, de inventar soluções, né, enfim, a gente tava ali muito pelo prazer de fazer, de aprender e não pelo dinheiro. Sempre foi uma marca muito forte. É isso, enfim... 


\section{APÊNDICE E - Transcrição Entrevista BAPTISTA}

Entrevistado: Alceu Baptista (AB)

Entrevistador: Maria Luiza Dias de Almeida Marques (ML)

Local: São Paulo- SP

Data: 30 de outubro de 2013

Duração da entrevista: 83 min

ML - Fala um pouco da sua formação e o que te levou a trabalhar com animação e efeitos?

AB - Na verdade eu comecei fazendo engenharia, na Poli, eu queria aprender as fazer as coisas com as quais eu queria mexer, uma delas era um computador gráfico, era uma coisa meio mitológica naquele tempo, não que não existisse, mas que a gente conhecesse; e outra coisa, eu queria montar um sintetizador para fazer música eletrônica, e mesmo não sendo músico. Minha razão de entrar na engenharia, era construir coisas que eu jamais achava que seria capaz de conseguir de outra maneira; eu vim de uma infância humilde e não tinha nenhum poder aquisitivo, era classe média baixa e etc., minha expectativa de comprar um sintetizador era uma coisa quase impossível, então era o meu sonho de garoto. Cheguei na engenharia e descobri que eu não ia conseguir fazer nada disso. O curso de engenharia era uma coisa mais burocrática, mais voltada para você ir lá e trabalhar com uma empresa e etc.; engenharia criativa, pelo menos me pareceu a princípio ali, um sonho que não ia se realizar e eu também não consegui me adaptar bem e ficar 24 horas estudando, porque era período integral e super puxado, não dava tempo de desenhar coisa que eu gostava de fazer, e eu resolvi mudar para ECA, e fui fazer artes plásticas. Prestei então novo vestibular e fui estudar Artes Plásticas e lá dentro das Artes Plásticas eu fazia tudo, menos Artes Plásticas por que eu não conseguia e não consigo até hoje me entender com arte contemporânea e eu pensei que eu fosse aprender lá uma coisa mais ligada ao que eu gostava de fazer que era ilustração e essas coisas, e não tinha nada; ao contrario, eu ficava sendo batendo cabeça com os Professores e eu não entendia o que eles estavam ensinando e talvez eu fosse muito ingênuo e tinha muito pouco repertório para entender aquilo, mas eu fui sendo um aluno médio dentro das Artes Plásticas e nesse meio tempo eu fui para o teatro, cinema, radio e TV e eu ficava fazendo aberturas de vinhetas no radio e TV, ficava fazendo trabalho de arte para abertura de filmes do super 8, ali na Escola de cinema, e eu fiquei ali rodando por tudo e foi muito bom ter esse contato com tudo isso. Minha formação é essa, acabei me formando, 11 anos depois, Licenciatura Artes Plásticas.

ML - E o que te levou a trabalhar com efeitos e animação, foi já graduação ou uma coisa puxa a outra?

AB - Na época, enquanto eu estava entrando, eu estava na transição da Poli para Eca, apareceu um fenômeno chamado Star Wars, aí eu fui ver Star Wars e aí, não vou dizer, mas eu era ultra nerd naquela época e eu gostava de Star Track, gostava daquelas coisas que estavam esquecidas, eu só lia ficção cientifica, eu era um problema na Poli porque eu era artista demais, e eu vim a ser um problema na Eca porque eu era tecnológico demais, não tá nem lá e nem cá. Aí, diante do Star Wars que eu fiquei chocado com a qualidade dos efeitos e com o sucesso deles de fazer uma Space Opera, não morri de amores pela historia, e tal, mas eu me apaixonei pela coisa dos efeitos mesmo, e eu resolvi que eu queria fazer um filme de ficção cientifica, eu, e fazer os efeitos e ia fazer tudo, eu ia dirigir e fazer os efeitos e talvez até atuar. Infelizmente eu não sou tão proativo assim e eu não acabei fazendo, senão alguém teria isso para mostrar e seria um fiasco. Mas eu me meti a querer trabalhar com isso, a querer fazer efeitos especiais. Mais o que eu fazia para ganhar a vida, os poucos trabalhos remunerados que eu tinha, eram os trabalhos de ilustração, eu fazia pintura a óleo e por acaso eu estou com um trabalho dessa época aqui, um teste de óleo sobre papel. 
ML - Posso depois fotografar?

AB - Sim. Então eu fazia essas coisas, eu gostava de ilustrar, trabalhava para revista e editorial; mas só depois da ECA, eu casei com uma aluna da ECA que eu conheci lá e aí eu comecei a trabalhar mesmo com isso e comecei a tentar me meter trabalhar com efeitos especiais. Durante o curso da ECA eu construí uma espaçonave, eu tenho umas fotos aqui se você quiser ver, e não cheguei acabar, mas foi feita para matérias do currículo, matérias um pouco mais aberta que você tinha meio que, você podia escolher o que você queria fazer e alguns Professores foram bastante flexíveis comigo e me permitiram construir uma espaçonave e eu fiquei meio famoso na ECA por conta dessas loucuras que eu fazia. Fazia fantasia para o pessoal do radio e TV, spok, Indiana Jones.

ML - você lidava com látex, com foam, com aquelas coisas todas?

$A B$ - A tecnologia no látex era uma coisa muito secreta e muita pouca gente sabia como fazer a vulcanização do látex...

ML - quais materiais você usava?

AB - Madeira, plástico, isopor, resto de kits, sucata industrial para construir meus modelinhos, as armas, as coisas assim.

ML - tampinha de pasta de dente?

AB -Isso, depois eu te mostro as fotos.

ML - O que te levou a trabalhar com isso?

AB - Então eu comecei a querer trabalhar com isso, fiz outra espaçonave dentro da ECA, para fazer para uma longa metragem de um colega, por que precisava de uma cena que tinha uma espaçonave...

ML - Era quem?

AB - Não lembro o nome dele, eu sei que era um dos Volpato. Não era o Carlos Adão Volpato, era outro Volpato. E o longa era sobre a infância em São Jose do Rio Preto que era a terra dele, e que tinha uma cena em que o menino deseja ver uma espaçonave e eu consegui financiamento básico, mínimo do mínimo pra construir uma nave. Eu passei 06 meses em casa construindo, eu e um amigo. E aí falei "quero entrar nisso", e comecei a procurar, e de vez em quando conseguia marcar para ir em agência, eu levava a espaçonave para mostrar. Um dia apareceu à chance de fazer um efeito especial para um comercial, um cara de efeitos se interessou pelo meu trabalho e me convidou para ir trabalhar com ele em outro efeito especial, uma propaganda de cigarros, e aí eu fui lá e resolvi que eu não queria mais trabalhar com isso por que ganhava muito pouco, virava muito a noite, trabalhava demais; e eu continuar fazendo a minha ilustração em casa, meticulosamente e com todo o conforto do meu estúdio, era mais negócio.

ML - você lembra qual agencia e qual o cigarro que era?

AB - O cigarro era... Se não me engano era o Galaxy, falava "existe uma maneira mais fácil de cortar a nicotina do seu cigarro, e tinha uma serie de comerciais usando essa frase, então um tinha o samurai que cortava o cigarro, outro tinha uma traquitana e uma guilhotina e cortavam o cigarro e tal. Esse filme era um observatório gigante, tinha uma lente enorme e concentravam os raios de sol e cortavam o cigarro com o raio de sol.

$A B$ - Acho que nem a agencia e nem a produtora existem mais. 
$M L$ - esse foi o seu $1^{\circ}$ trabalho que você concluiu?

AB - Concluímos a duras penas, mas eu não era o profissional sênior na historia, eu era o auxiliar de um Argentino, Barquinero, que era o efeiteiro. Era o que se chama agora de traquitaneiro, o cara que faz efeitos.

ML - Como que ele chama?

AB - Barquinero. Nunca mais ouvi falar dele, ele era Argentino, eu não sei se ele voltou para Argentina, e não sei o que ele faz hoje. Vou procura-lo no Facebook.

AB - O nome do diretor é Renato Volpato se não me engano. A gente vai confirmar no Google. E aí eu falei "não, é roubada", percebi que a área de efeitos especiais era muito quarto de empregada da propaganda, apesar dos caras serem superimportantes, super engenhosos, puta gênios e tal, mas era um negócio super de pião. Pago como último escalão e tratado como ultimo escalão, então eu falei "não, bobagem, vou continuar com minha ilustraçãozinha". E continuei trabalhando, trabalhei para revista Erótica, comecei a trabalhar para a agência que pagava mais ilustração, mas não deu tempo de eu chegar num escalão mais alto dentro da ilustração, mas eu era bom, eu era bem acima da média na época.

AB - Aí um belo dia, começaram aparecer na televisão as vinhetas do Hans Donner, as aberturas do fantástico feitas em computador.

ML - Em 84, 85?

AB - Por ai, em 84, acho o que foi em 83, 84, dá para conferir no Youtube. E todo mundo ficava encantado com aquilo, mas a gente não sabia bem o que era e como fazia. $E$ eu comecei, dentro da universidade tinha a acesso ao material da biblioteca, então eu adorava pegar a American Cinematographer, e lia tudo e vasculhava tudo, Cine Fax que a gente conseguia pegar, lia e devorava tudo, lia várias vezes porque eu tava muito empolgado e começou... E a $1^{\text {a }}$ vez que eu vi o TRON 10.30, Tron Original, eu olhei e falei "não é possível que o computador faça isso, isso deve ser aerografado em cima de computador e tal", e comecei a me interessar por aquilo. O que me incomodava no meu trabalho de ilustração, eu tava descobrindo na época que eu jamais seria um artista plástico, eu ia ser llustrador porque eu gostava de contar historinhas. As minhas ilustrações, você falou que vai falar das minhas ilustrações, das minhas referências, eu adora o Frank Frazetta que era um ilustrador que pintava Conan e pintava aqueles bárbaros, com espadas, contra dragão, aquela coisa que é meio... Hoje você vê que é cafona, mas eu achava bacana, eu gostava de ficção cientifica, então gostava de pintas espaçonaves e mulheres vultuosas e com roupas de guerreiras, aquele negocio bem dos anos 70. A Revista Heavy Metal, desenhos, Moebius; Felipe Dreyer era outro que eu gostava muito; o pessoal todo que ilustrava Heavy Metal, chegava aqui como Heavy Metal, revista francesa, mas chegava aqui a versão americana, então esses eram meu ídolos e eu contava historinhas da ilustração e ficava faltando a $4^{a}$ dimensão que era o tempo, eu conseguia fazer cena congelada, e eu queria fazer em movimento, por isso que eu queria fazer o filme de ficção cientifica. E não tinha recurso, não tinha dinheiro para filmar super 8 , a gente até, o pessoal da ECA, os amigos, a gente se juntou para tentar fazer um filme super 8 , mas a gente não tinha noção empresarial da coisa, a gente não pensava em termos de levantar recursos, de procurar gente para patrocinar, ninguém ali tinha essa mentalidade empresarial que talvez nos tivesse permitido fazer uma experiência dessa, mas a gente ficava contando com o nosso próprio trabalho em horas de folga e aos finais de semana, então ninguém aguentava tocar um produção desse tamanho OU que fosse um pequeno cenário de espaçonave, ninguém conseguia fazer isso.

ML - depois eu quero saber o truque ali, é magnético? 
AB - É magnético e depois eu te explico. E depois apareceu, a gente ouviu falar e começou a circular na imprensa, o curso da GloboTEC e o Objetivo, iam oferecer um curso pra formar profissionais nessa área de tecnologia digital para televisão.

ML - e você lembra em que época foi?

AB - Esse curso a gente teve noticia em 84 e o curso foi ao longo de 85 . Circulou na imprensa e foi na mesma época que o Hans Donner fez a $1^{\mathrm{a}}$ exposição dele, na galeria de Arte de São Paulo, todo mundo foi, porque ele era o gênio do design naquela época; hoje em dias as opiniões são, todo mundo torce o nariz, meio azedo e tal, da existência do Hans Donner, mas o trabalho dele foi uma tremenda ruptura dentro da imagem de televisão no mundo e não só no Brasil, o que ele tava fazendo despertou interesse no mundo inteiro, só que eles não faziam aqui no Brasil, eles não tinha computador para fazer aqui, na época tinha aquela Excrescência, lei da informática, dizia que você não pode importar computador, e aqui não se fazia computador para se fazer isso; então Hans Donner fez aquela exposição, começou aparecer essa historia do curso da GLOBOTEC, as pessoas juntaram uma coisa com a outra e começaram a achar que o Hans Donner estava dando o curso da GLOBOTEC.

E eu alucinei, eu falei "eu preciso entrar nesse negocio, isso é o que eu quero fazer, tenho que ir atrás", mas tinha um vestibular meio serio, um vestibular para entrar, e o curso era pago e caro e também nessa altura eu tava casado, minha mulher na época que era jornalista, ela falou: "ok, faz o seguinte, você pode parar de trabalhar, para de fazer ilustração e vai estudar para esse vestibular ai, e eu te sustento", por que assim, o dinheiro do mês ela providenciava porque ela tinha emprego fixo, e eu ganhava eventualmente uma quantia maior e a gente comprava TV, vídeo cassete, os grandes valores eu providenciava eventualmente e ela mantinha o dia a dia. E ela falou: "pode dar um tempo na ilustração e vai estudar", eu tinha que aprender a programar em Basic que era uma exigência, e eu só tinha mexido com computador na Poli, num grande computador e usando cartão perfurado, e já tinha revolucionado essa área; aí ia ter prova de desenho, prova de Matemática, português, inglês, um vestibular serio. E eu falei: "eu tenho que ir, eu tenho que fazer", e eu fui, prestei o vestibular e entrei; levei a espaçonave para os caras verem, todo mundo caiu de costa.

ML - você se lembra de outras pessoas que entraram junto?

AB - Gilberto Caserta que hoje está envolvido... O pessoal do Painel do Anhangabaú, que eles tinham o $1^{\circ}$ painel digital.

AB - O Almir?

AB - Não. O Geninho, o Shonki e o Silvio, que eu não o sobrenome. (16.07) E eles eram responsáveis pela animação do painel do Anhangabaú, era no tempo das diretas. $E$ foi interessante conhecer os caras, porque só pelo que eu via no painel eu me identifica pra caramba. E outras pessoas, a leda que casou com o Geninho. O Professor Luli, não sei falar o sobrenome dele, mas ele fez esse curso. Wagner Inocêncio. Walter Rasaki.

Eu sei que juntou lá umas 50 pessoas, cada um vindo de uma área, que eles conseguiram selecionar e foram fazer o curso. A nossa expectativa era de fazer, de vir a trabalhar com 3D, computação gráfica como chamávamos na época. O curso mostrou pra gente, fitas do que era feito no exterior, e a gente via aquelas animações que hoje são breguinhas e simplezinho, mas naquela época parecia extraordinário, era um novo tipo de imagem que tava sendo criado e que ninguém tinha visto, assim como quando apareceram os primeiros sintetizadores, "musica eletrônica, que demais e tal", havia esse encanto com aquela imagem que era diferente do que todo mundo conhecia. Aquelas câmeras que faziam imagens tridimensionais suaves, sem tremer; o que era de imagem aérea que a 
gente conhecia e que não tinha steady-cam, era tudo tremido, tudo balançando e tal; de repente sobrevoava uns prédios, nem que fossem prédios estilizados, mas com movimentos ultra suaves, aquilo era um coisa nova, uma percepção nova de movimento em televisão e em vídeo.

E ai, a gente fez o curso, mas infelizmente para nós, aquilo era uma iniciativa da GLOBOTEC São Paulo, infelizmente ou felizmente, porque ao fim a gente conseguiu, de um jeito ou de outro a gente conseguiu. A GLOBOTEC São Paulo através do diretor que foi o incentivador e promotor desse curso, se chamava: Cauby Sampaio do Monte, ela resolveu criar um curso aqui, pra tentar criar o Profissional que era o mix entre o Hans Donner e o José Dias; na época das grandes vinhetas do fantástico, e do Hans Donner e tal, o Hans Donner criava e levava a fama, mas quem produzia era o Jose Dias que é um matemático, e eu tenho contato com ele até hoje pelo Facebook e tal, era um Matemático e dirigia em parceria com a Pacífico DATA IMAGE de Los Angeles, a criação de software para gerar a imagem tridimensional, que era uma coisa muito complexa naquela época de se trabalhar, era tudo programação, e se você quisesse modelar um objeto, você tinha que entrar com os vértices numericamente, e não tinha esse negocio que hoje tem: os Z-brushes, que você esculpe uma pessoa humana que nem o Michelangelo, com toda musculatura e veinha e tal, e só você passando a caneta em cima de alguma coisa. Naquele tempo era tudo muito programado.

ML - Imaginar muito...

AB - Sim. Há necessidade de você ter uma pré visualização tridimensional dentro da sua cabeça, antes de você começar a fazer qualquer coisa, isso era muito serio; então o Cauby apostava que poderia surgir o profissional que tivesse um pé em cada área, e que era justamente nós, os caras que eram rejeitados nas artes e na tecnologia porque estavam no meio do caminho, então ele conseguiu juntar esse pessoal, mas infelizmente por conta de disputa interna dentro da Globo, ele não conseguiu trazer um computador gráfico que estava sobrando na Globo, era uma máquina baseada em PC, chamada CUBICOMP PICTURE MAKER, era uma máquina que eles tinham na Globo e que tinha uma capacidade gráfica inferior, e eles estavam fazendo as grandes coisas mesmo na Pacific Data e eles não conseguiram trazer o grande computador para cá, no PD P-11 INOVAX, que era um computador de maior porte.

ML - e porque era de maior porte?

AB - Era o que eles chamavam na época de MAINFRAME, não era uma coisa do tamanho de uma casa, mas era do tamanho de duas geladeiras.

ML - esse CUBICOMP...

AB - Era um PC, baseado no IBM PC da época. Que era mais ou menos o que a gente tem hoje aqui, só que infinitamente mais fraco. Então era um IBM PC envenenado com placa gráfica e com outras, vamos dizer, falcatruas de hardware ali, para ele ser capaz, usando a tabela de calculo dele, para gerar imagem, então era um PC adaptado.

ML - esse curso era dado até certo ponto sem a máquina?

AB - Sem a máquina.

ML - aulas teóricas?

AB - Não tínhamos aulas teóricas, a gente tinha, a ideia do curso era muito bacana, porque a gente tinha aula de inglês para poder estudar manual, poder falar com o pessoal, para 
poder ir as feiras e conversar, e ter aula com quem fosse necessário, e a gente tinha aula de inglês. A gente tinha aula de programação em basic, muito básica, supondo que a gente fosse ter que fazer alguma programação. A gente tinha aula de arte. Era muito abrangente, tinha bastante coisa. E a gente tinha aulas praticas dentro da GLOBOTEC, eles permitiam que a gente entrasse na GLOBOTEC e tivesse contato com o que havia de tecnologia digital disponível naquele tempo. A gente tinha o Ultimate, equipamento para recortar as pessoas e aplicar em outro fundo, na verdade era o NEWSMATE, era a versão mais barata; o pessoal comprou aqui a versão de jornalismo, que era uma versão menos sofisticada do Ultimate, que era aquele sistema que removia digitalmente o fundo azul e era capaz de colocar uma imagem atrás de uma pessoa que tava lá no estúdio. E havia também o A.D.O

ML - ele fazia também composição, justaposição?

AB - Seria uma COMP de certo modo, mas era...

ML - lembra da abertura do Armação llimitada?

AB - Lembro do programa e não lembro da abertura.

ML - abertura é incrível, eles aparecem e vira um aspecto quadrinhos ...

AB - Ah sim, tinha PAINT SYSTEM DIGITAL

ML - Aqui no Brasil?

AB - Aqui no Brasil, era os primeiros PAINT System também baseados em PC, mas eles tinham um esquema dentro da GLOBOTEC e tinha tudo instalado e que permitia que você parasse um frame e pintasse em cima, dava até para você fazer ilustração, então eu trouxe para dentro do digital, a minha habilidade como ilustrador, e o que foi um choque para os caras que trabalhavam com tecnologia, porque os caras vinham de uma formação tecnológica, quando eu apliquei a ilustração ali, ninguém acreditava no que eu conseguia fazer: "nossa! Como você desenhou isso, e como você fez isso", ninguém entendia: "isso aqui é um simples truque de ilustração", então a gente conseguia fazer umas coisas que ninguém conseguia e esse foi o segredo da VETOR no começo.

ML - esse curso prometia alguma coisa: "você faz esse curso e você ta com o pezinho na globo e tal"?

AB - Eles tinham prometido uma viagem para o melhor aluno, talvez os 03 melhores alunos iriam viajar e fazer um curso fora, fazer um curso na GLOBOTEC e talvez fazer um estagio na GLOBOTEC, não prometiam emprego, mas todo mundo tinha uma expectativa de que ia trabalhar lá, pelo menos experimentar trabalhar com o computador $3 \mathrm{D}$, mas isso não aconteceu. Infelizmente o curso acabou, o José Dias achava que a GLOBOTEC ia criar uma concorrência em São Paulo, para a empresa que ele queria montar: a GLOBOGRAPHIC, uma empresa para fazer efeitos para propaganda, então ele tentou bloquear e o pessoal não conseguiu trazer o computador para cá, então ficamos sem computador. Mas a gente teve contato com o ULTIMATE, a gente brincou dentro da GLOBOTEC, a gente brincou com A.D.O., a gente fez trabalhos experimentais.

ML - era lá no centro da cidade, em Santa Cecília?

AB - Não. Era na Maria Antonia.

ML - não era perto da Marechal Deodoro? 
AB - Não. Ali era o estúdio da globo. A GLOBOTEC funcionava numa rua que cruza a Consolação.

ML - eu fiz um estágio lá também, eu ia fazer um estágio em 91 , eu fiquei indo lá varias vezes, eu fiquei colando nos caras e foi a $1^{\text {a }}$ vez que eu vi um mouse.

AB - 91 a gente tava meio fora de lá. Talvez o Alex estivesse lá, não, não, ele também não estava. $E$ foi um cara que deu aula pra gente, um cara muito ligado a essa tecnologia nova. Então fomos fazer esse curso, o pessoal do curso ficou muito frustrado porque não conseguiu ter contato com a tecnologia.

O que foi bonito nesse curso, foi que botou um monte de gente junto e que tinha afinidade com essas coisas, em maior e menor grau de tecnologia ou arte. E a gente ficava trocando figurinha lá. E o pessoal aparecia com revista: "olha aqui, saiu o CUBCOMP DO PICTURE MAKER 2.0 e custa 20 mil dólares, e se a gente conseguisse alguém que tivesse 20 mil dólares", e tal.

E aí apareceu a grande estrela tecnológica que surgiu nessa época, era um computadorzinho caseiro, chamado AMIGA, que era uma evolução do Commodore 64, que era um computador de mil dólares, mas que tinha uma capacidade gráfica, veja, o que você tinha naquela época? Quem fazia animação? Você tinha o José Dias que fazia animação para a Globo; você tinha umas duas empresas trabalhando com CUBiCOMP PICTURE MAKER, uma era da ... 26.47 Pixel, chamava Pixel; e tinha o Ormeu que tinha lá no Rio a empresa AZIMUTH, mas ainda em estágio embrionário. E tinha o pessoal que trabalhava com Apple II, e que fazia umas animaçõezinhas e tinha até um programinha chamado TAKE FIVE e que permitia fazer animaçõezinhas 2D rudimentar, mas o pessoal trabalhava com isso e fazia animação institucional de baixa resolução e em escala bastante precária, por que? O Apple, o hardware dele não permitia que todos os pixels tivesse todas as cores, então o azul só tinha a cada duas ou três colunas, verde só tinha em colunas impares, então se você quisesse uma linha azul continua, ela só funcionava na vertical e na horizontal ficava quebrada, então para você conseguir determinadas cores ali, era uma combinação de pixels, uma coisa meio da idade da pedra. E o Gilberto Caserta tinha uma empresa que fazia isso. Eu cheguei a virar, eu cheguei a pegar um job pra vetor, o que não existia e fui fazer com o Gil.

E bem, aí apareceu esse AMIGA, e todo mundo: "que legal, esse Amiga, bárbaro e maravilhoso", eu fiquei assanhadíssimo, mas o curso passou e ninguém tinha dinheiro para comprar o Amiga e tinha que contrabandear porque era proibido trazer aqui. E o curso foi terminando e eu fui voltando pra ilustração, afinal não tinha conseguido emprego e não tinha rolado a história do computador gráfico. E aí o Serginho Sales, estudante da ECA na época, tinha uma produtora de vídeo chamada V-TV e aí ele queria fazer um panfleto para a produtora dele, e os amigos em comum recomendaram: "vai fazer com o Alceu, ilustrador, o cara é bom pra caramba", e ele foi, ele foi em casa com o sócio dele, e falaram: "quero uma arte assim e assim", e eu fiz uns esboços para ele. E no dia em que ele foi para escolher um deles, eu falei: "Serginho, olha esse computador aqui, da uma olhada nessa revista, porque você não compra um desses, e aí você me chama para trabalhar, e aí a gente faz os gráficos dos seus filmes e dos seus vídeos". "Eu tenho curso, assim e assim e assado". E ele falou "interessante, vou pensar". O gênio do business que ele é, ele voltou e falou: "Alceu, nós não vamos fazer isso não, eu não vou comprar um computador e te contratar, mas eu vou sair da V-TV, vou vender minha parte e nós vamos comprar uma Amiga e vamos montar uma empresa para fazer isso dai". Eu falei "uau, que Maximo, eu nem acreditei". E foi o que aconteceu, a gente conversou como ia ser; um cara boa gente, dois bons meninos vamos dizer assim, ninguém muito mesquinho, com bom senso, interessados em trabalhar juntos e sem levar vantagem, e nos associamos, fizemos lá e compramos Amiga. Foi um evento a chegada do Amiga aqui.

ML - como vocês conseguiram comprar o Amiga? 
AB - O Serginho conhecia... Tinha os Deallers. Ele comprava equipamento para a produtora dele. O único jeito de chegar equipamento aqui era por contrabando, era tudo fechado e nem Hospital podia ter coisa digital; carro não podia ter injeção eletrônica; não podia ter imagem de tomografia; não podia entrar nada digital no Brasil, na época havia reserva de mercado para aquelas empresas que ficavam mamando, e atrasou o país em 30 anos, até hoje a gente ta atrasado por conta disso. Então ele conseguiu lá um dealer que ele já tinha feito um trabalho, e o pessoal em geral que faz contrabando é muito honesto, porque eles dependem do boca a boca, alguns chegavam até a reembolsar caso a mercadoria fosse apreendida, eles reembolsavam o cara, para não transferir o prejuízo para o cliente, então a gente comprou o Amiga e ficamos 03 meses na expectativa de chegar, e ficamos lendo, e eu só pensava naquilo, ansiedade e tal. Quando chegou, chegou no RJ e o Serginho falou: "chegou no RJ e vão levar mais tempo para chegar em São Paulo, e eu vou buscar lá", e ele foi até o RJ e fez um bate e volta com um amigo, e eu fiquei esperando no meu Apartamento o pessoal voltar e assim, metade do pessoal do curso da GLOBOTEC estava lá esperando o computador chegar. E chegou, montamos o Amiga, ligamos o computador e fez um barulhinho, apareceu para botar um disket e a gente colocou o disket do sistema operacional e aí apareceu para por outro disket, colocamos e aí apareceu uma tela colorida...Oh! tinha 32 cores simultâneas na tela e a gente nunca tinha visto, foi um acontecimento. E aí começamos trabalhar com Amiga e não tinha os softwars, não tinham chegado, e eu comecei a mexer com aquilo, e comecei a programar em basic, as coisas que eu tinha aprendido na GLOBOTEC, comecei a fazer no Amiga e comecei a usar os recursos que tinha, desenhar num Paint System Rudimentar que eles tinham lá. E quando o softer chegou, no dia seguinte entrou no job, SENAC, foi o $1^{\circ}$ trabalho, e a gente conseguiu nesse $1^{\circ}$ job pagar o computador. Afinal eram mil dólares.

ML - em que ano foi isso?

AB - 85 para 86. E a VETOR foi registrada como empresa em janeiro de 86.

ML - esse filme ainda existe?

AB - Eu pedi para o pessoal da chapa buscar, eu sei que tem gravado. A gente precisa garimpar porque eu não sei onde está. A gente começou a fazer uma serie de animações 2D por que não tinha poder e nem capacidade gráfica para fazer 3D.

$M L-2 D$ direto no computador?

AB - Direto no computador, com mouse; eu tinha meu estúdio de ilustração no meu quarto, onde eu morava com minha esposa e tal, e eu tirei os pincéis para um lado e comecei a mexer no computador direto. $\mathrm{E}$ aí começamos a trabalhar e começar a ganhar dinheiro com isso. E a gente ficou trabalhando só 2 anos com Amiga, compramos outro Amiga e eu me separei; mudamos para uma casa onde eu morava e tinha a Vetor, 02 Amigas, convidamos amigos para trabalhar juntos; mas a gente não conseguia ganhar dinheiro e sair daquele mundinho pequeno e a gente tinha qualidade bastante apreciada na época, na categoria de vida empresarial, por que justamente eu tava transportando o meu conhecimento de ilustrador para animação 2D; então a gente pintava elementos, não dava para fazer metálico de verdade, mas a gente pintava umas coisas que pareciam metálicas, e para os olhos destreinados das pessoas da época, aquilo parecia metálico: "como vocês conseguem fazer metálico, eu não consigo?" Pintura, ilustração. E aí a gente conseguiu um bom nome no meio, mas a gente tava ali na $2^{a}$ categoria, LOW-END do mercado; HIGH-END era produzir 3D para comercias, coisa que o Dias fazia, a Pixel fazia e o Azimute fazia e outros que eu não lembro. A CASABLANCA na época chamava de DIANA; e tinha outra empresa INTELIGENT LIGHTS e que tinha um outro computador que imprimia direto em filme; muita gente tentando fazer isso, tinha o ARMIC, que tinha um computador AliaS também, e ele fazia algumas vinhetas e tal. 
ML - em que mídia o trabalho era entregue para o cliente?

AB - Em película para depois ser telecinado, porque não havia meio... Havia sim, se você tivesse todo um sistema de time-code e máquinas de uma polegada, você conseguia editar em vídeo, frame a frame, coisa que eles faziam, a GLOBOTEC E A DIANA. E quem não tinha esse recurso, passava para película, um chamado Filme PRINTER. 35.35

ML - você levava o seu HD...

AB - Não, tudo estava no mesmo sistema. Tinha ali tipo uma câmera de cinema chamada FILME PRINTER e o cara lá, no próprio estúdio dele, onde ele produzia animação no computador, ele imprimia no filme.

ML - e vocês?

AB - A gente passava direto para o vídeo, para o nosso trabalho já saía em Play, mas veja, a gente tinha que usar um truque porque o play do Amiga, não era um Play Smooth, não era um play constante, ele variava em função ao que o computador estava calculando naquele tempo, e ele era meio quebradinho; pra evitar esse quebradinho, eu e o Serginho, conversando, experimentando, vimos um jeito que era gravar, tocar a animação... Detalhe o Amiga tinha uma saída direto para vídeo, e era o que os outros também não tinham, então você gravava no VHS ou você gravava no U-Matic, na saída de vídeo do Amiga, embora fosse um vídeo meio escuro, meio assim, não muito legal do ponto de vista técnico, mas dava para gravar direto do computador. Então a gente soltava a animação em super SLOW MOTION, porque aí o computador conseguia usar mais ou menos o mesmo tempo para calcular cada FRAME; e aí a gente ia para uma empresa que tinha um sistema um pouquinho melhor de Vídeo U-Matic, e a gente fazia um tape do tape, em fast Speed, então a gente acelerava a animação, para que ela finalmente ficasse no tempo.

ML - tinha uma perdinha de geração...

AB - Tinha, mas era irrelevante, a gente entregava a animação em VHS ou em U-Matic, a qualidade era péssima já; mas ainda assim era um bom trabalho.

ML - e o som...

AB - Colocavam depois. A gente não se ocupava do som.

ML - nessa época bem inicial, como vocês bolavam o orçamento do filme?

AB - Orçamento de trabalho, na época havia um mito de que era por segundo, mas não é; eu trabalho em função de uma estimativa de prazo, de tempo que você ia gastar fazendo. Não vou dizer que era um chute, era um chute bem assim elaborado: "isso aqui vai dar muito trabalho e vai custar X", mas eu nunca fui muito bom nisso, quem fazia essa parte era o Serginho. E tinha que negociar com o cliente. Agora havia empresa que cobrava por segundo, havia um mito sim, de que eram 500 dólares por segundo. Um segundo de bolinha pulando, era mais difícil do que um segundo de espaçonave passando, então, esse negócio de por segundo era muito duvidoso.

$M L$ - então você tinha falado que nessa $1^{\text {a }}$ etapa vocês descarregavam em VHS ou matic. $E$ vocês tinham lá a ilha, estaçãozinha de U-matic?

AB - Não tinha. Era muito caro pra gente ter uma máquina de U-matic. A gente levava o Amiga numa produtora que o Serginho acabou encontrando, a VIDEOLAR, que era... Aliás, 
a princípio a gente levava numa produtora que tinha esse mecanismo, e a produtora parou de trabalhar com isso, e aí deu um desespero no Serginho, entrou em pane, e como ele é um bom cara e de iniciativa, ele descobriu a VIDEOLAR e a gente estabeleceu uma relação de amizade com eles. E eles tinham essas máquinas de U-matic com time-code, e permitia gravar o sinal do Amiga e depois fazer o Fast... 39.46, e a gente passou a trabalhar com eles. Então o processo era esse, nosso sonho era trablhar com 3D claro.

AB - Tinha outra empresa, ARTE SISTEMAS, e um amigo meu foi trabalhar lá, que era uma empresa similar à nossa e tal, mas eles tinham maquininha de U-matic, e eles tinham até um computador baseado em placa targa que permitia fazer o trabalho de edição quadro a quadro. Pra você ver a animação em play, o único jeito é transferir para quadro pro vídeo, e só então depois de gravado você ia assistir aquilo; com exceção do Amiga que saía o play direto, mas o Amiga não era 3D, o Amiga era uma coisa mais simples; então ele conseguia dar play... 40.50, do que ele tava calculando na hora. Os computadores 3D não, eles geravam a imagem, e acionavam, gravava aquele disco em HD e você tinha que chamar a imagem e editar no vídeo. Como que se fazia isso? Manualmente, aquele método bobão minhoca. Bobão é o cara que fica ali no computador apertando "próxima imagem", e aí carrega a imagem lentamente, quando ela tava na tela "o minhoca", era o cara que apertava no vídeo mais um edite, e a máquina dava um pré hold 5 segundos e ia lá e editava. $\mathrm{E}$ assim você ia vendo a sua animação quadro a quadro. Depois de 8 horas você via 10 segundos de animação. E aí você via se o negocio tinha ficado bom ou não.

ML - então o Amiga não fazia esse aspecto $3 \mathrm{D} \ldots$

AB - Não.

ML - 3D, pente...

AB - Num dado momento, começaram aparecer softers 3D para o Amiga, mas era uma coisa muito rudimentar, você conseguia fazer o modelinho básico. Eu lembro que a gente fez uma animação para apertura para o Vídeo Brasil, em 87 e a gente tinha ido para SIGGRAPH a convite da GLOBOTEC, e os caras gostavam do meu trabalho, e eles queriam que eu fosse trabalhar lá, e eu falei "tenho uma empresa que ta funcionando e eu não vou trabalhar ai", então eles pegaram os caras do curso (um deles falou comigo hoje aqui, Walter Carvalho), e eles iam trazem um computador, e eu querendo comprar um computador pra cá, e aí me chamavam lá, e o Cauby que gostava de mim e era meu padrinho, ele me pagou uma viagem ao SIGGRAPH (Special Interest Group on GRAPHics), em 1987, e eu nunca tinha viajado para o exterior, e ele também pagou um curso, pagou não, me ofereceu um curso na GLOBOTEC do Rio, quando eles estavam lá com o CUBICOMP emprestado, escondido da Globo. E o Professor que dava aula lá, escondido da Globo, ele trabalhava na Globo com o Hans Donner, mas ele foi escondido dar aula pra gente, porque o Dias não podia saber. E ele me convidou e eu passei um mês no RJ e foi uma delicia, eram 04 horas de aula por dia e o resto era praia, lá no Rio Othon, e todos os gastos da GLOBOTEC, passagem para ir e voltar ao final de semana, coisa mais linda. E eu falava "Caubi, eu não posso me comprometer em trabalhar com você", ele: "isso aí é que você fez o curso, foi melhor aluno e não sei o que ...". Então eu aprendi a mexer no CUBICOMP, foi na época que a Vetor ainda tava no Amiga. Aprendi o básico do CUBICOMP, cheguei lá e comecei a fazer minhas espaçonaves,

E o Professor falava: "ninguém faz isso lá na Globo", "como você fez isso", eu: Pintura, tudo pintura, tudo pintada e tudo extração. Ele: nossa, isso tudo é novidade. $O$ primeiro job 3D da Vetor foi feito num Picture Maker 60. O primeiro Job da Vetor foi no Cubicomp, mas antes disso a gente já brincava de fazer 3D no Amiga.

ML - eles já tinham mesa digitalizadora? 
AB - Tinham, canetinha,você podia usar o PUC ou a canetinha. Não usava mouse para modelar. A modelagem era no teclado, era marca o ponto e anda 03; marca um ponto e desce 03; vira; completa; extrude; menu sobe; poligon; extrude; volta; gira; seleciona; corta; boleana; tudo comando. Então eu aprendi esse básico durante esse mês, fui para a SIGRAPH, e aí cheguei à SIGRAPH e descobri que tinha programa do 3D para o Amiga. aí eu fiquei maravilhado, e eu fui lá e consegui comprar, trouxe para o Brasil e a gente começou a fazer, mas era muito rudimentar. Você conseguia gerar uma imagem, a gente fez para o Vídeo Brasil, uma cabeça em 3D de robô ali, que girava, e a gente conseguia gravar, 15 segundos, a 10 frames por segundo e ele dava play naquilo e a gente gravava direto. Quem fazia a animação 3D, mesmo esse tipo de CUBICOMP na GLOBOTEC, os testes que a gente fez, e a espaçonavezinha que eu fiz em direção a Jupiter e tal, era tudo ...45.13.

Só que na GLOBOTEC, como eles tinham dinheiro, eles tinham uma máquina de uma polegada, e tinham um equipamento que fazia essa gravação automaticamente, o computador fazia o RENDER, acionava a máquina, a máquina gravava, e passava o próximo...

ML - De uma polegada a fita magnética?

AB - É.

ML - Não é U-Matic?

AB - Não. aí já era uma polegada porque era profissional, coisa de Globo, GLBOTEC, outra categoria. E eles dispensavam o BOBAO-MINHOCA porque tinha esse método automático, essa placa que fazia isso; e nas empresas menores essa na mão mesmo. Aí um dia, o Senhor Levi, dono da ARTE SISTEMAS, chamou a gente porque um amigo nosso trabalhava lá, o Silvio Pinheiro; ele pegou um trabalho gigante para fazer, e ele foi a $5^{a}$ produtora a pegar o trabalho, e ele não sabia como fazer. E o Silvio falou: "se tem alguém que pode fazer é o pessoal da Vetor". E ele chamou a gente e mostrou o trabalho que teria que fazer, um vídeo de abertura para um institucional da Citrosuco, que tinha laranja voando, logotipo de vidro no espaço, caminhão da Citrosuco voando no espaço, sobrevoo de laranjal...

ML - como que os caras da agencia puderam criar tal coisa, se eles não sabiam ainda, o olhar estava ainda meio virgem para essa coisa de computação gráfica, não estava? Ou eles estavam antenados para o que acontecia no exterior, como eles inventaram isso?

AB - Na verdade, $1^{\circ}$, todo mundo pensava que era o computador que fazia, portanto, desde o começo o nosso trabalho foi estigmatizado como uma coisa não artística, porque as pessoas achavam: "isso aí é feito por computador", e aí as pessoas não tinham noção do trabalho humano que havia por trás. Outra coisa que acontecia, com base do que eles viam na televisão, eles imaginavam que qualquer coisa poderia ser feita digitalmente, na verdade as pessoas na época tinham a expectativa de que o computador poderia fazer coisas que só hoje a gente consegue fazer, 30 anos depois. Então para esse vídeo da Citrosuco, o meu cliente tinha expectativa de que o suco de laranja que ia preencher o logotipo de vidro, ele ia chegar jorrando, e splash em câmera lenta, coisa que hoje ainda é difícil de fazer, mas as pessoas achavam que já que é o computador que sintetiza a imagem, dá para fazer tudo.

ML - ilustração era meio que viável, imagino parada...

AB - Sim.

ML - os caras faziam aerografia... 
AB - Sim. Eu mesmo fazia essas coisas. Então, você tinha que educar e falar: "não é bem assim, a gente consegue fazer, mas tudo que você faz em 3D, é solido, não existe manipulação de liquido, tudo é polígono". "Se você tem uma bola, na verdade a bola é uma geodésica", e você tinha que fazer uma certa educação para o pessoal não viajar demais, mas a gente recebia coisa de criação, delirante. Mas assim, a expectativa que todo mundo tinha, é que a imagem fosse aquela coisa metálica, de alta tecnologia. Associava se a produção de computador a alta tecnologia, às vezes a gente tinha até que usar baixa resolução para ser mais evidente de que aquilo era computador. Se ficasse muito bem feito, o público da classe c não ia saber que aquilo era computador; e eles queriam que soubessem que era computador. Foi por conta disso que a VETOR conseguiu fazer até alguns comerciais pra TV, mesmo no sisteminha mais capenga que era o Amiga. Bem, e aí procurou a gente para fazer esse trabalho, a gente olhou, e eu estava com o Serginho. Ok, vamos conversar. Saímos de lá e eu falei para o Serginho: "viagem, delírio".

Ele: "nós vamos pegar esse job". "O Toni dono da VÍDEO LAR, ele quer entrar de sócio com a gente, ele quer comprar um computador 3D pra gente, e a gente pega esse job e com 0 dinheiro desse job a gente paga o computador". Olha a cabeça de empresário que eu não tinha.

Ele: "vamos fazer".

Eu: "você acha que a gente faz?"

Ele: "faz."

E aí a Gente juntou o nosso repertorio; nos fomos visitar um cara no RJ que tinha um CUBICOMP...Ai tem uma outra historia que envolve a escolha do computador. Mas 0 Serginho foi lá e falou com o Toni. O Toni era o dono da Vídeo Lar, e ele tinha duas grandes lojas de eletrônicos em Miami, onde os brasileiros iam fazer compras. Hoje é o outlet, e ele tinha lá a lojinha chamada VITOR que vendia eletrônicos, perfume e essas coisas todas, e ele tinha muito dinheiro. E ele falou: "vamos lá, vamos comprar o computador".

E ficou animado com a ideia. E aí coube a mim, ir lá e aprender a mexer na versão nova, ta saindo uma versão nova do CUBICOMP, baseada na placa raise que era muito mais rápida do que aquela que eu tinha experimentado, funcionando num computador 286 , e que já era um computador mais rápido, mas ele conseguia fazer o ReNDER rápido por causa dessa placa e que o sistema incluía um sistema de pintura que era... Não lembro, acho que era TIPS. E o CUBICOMP PICTURE MAKER, SISTEMA 3D, e um sistema para gravar. Para fazer essa gravação, acho que era o Vilan que fazia a gravação sem que você precisasse ficar editando na mão. E não dava tempo de importar o computador, era contrabando e não poderia importar. E a gente foi, (espero que não se volte contra mim essa historia de que usávamos contrabando), e aí qual foi o esquema?

O Serginho falou: a gente vai para Miami, aluga um Apartamento, instala o computador e faz o job lá.

Eu: ok, topei.

ML - isso tinha que estar no orçamento...

AB - Sim. Serginho pensou em tudo. E eu falei: "vamos lá, eu consigo fazer." E a gente foi lá e convenceu o cliente com toda honestidade; quase toda honestidade, a gente não falou que ia comprar o computador e montar lá. A gente falou que se associou com uma empresa de Miami que tem o computador e que eu ia lá, e ia sentar no computador dos caras, e ia fazer, usando o computador do pessoal dos Estados Unidos. Isso para não deixar os caras inseguros, em relação a essa coisa domestica. E aí a gente foi. Conseguimos comprar o computador...

ML - se você pudesse falar a escolha do computador e o que norteou para esse e não aquele... 
AB - Todo mundo na época queria comprar o WaVEfront 52.53 , era o computador que tinha a fita mais impressionante. Na época era separado o que você tinha disponível no mercado, você tinha no HIGH 53.03, computadores de topo, que funcionavam com estações SILICONGRAFICS, você tinha o ELIOS, ELIOS POWER LIMITED, Tinha o WAVE FRONT Tinha o VERTIGAL, que passou a ser CUBICOMP na época. Foi comprado pela CUBICOMP, um sistema canadense. Acho que todos eram canadenses, não tenho certeza agora. E tinha INTELIGENTE LIGHT que era uma outra empresa menor. E SOFT IMAGE. Depois entrou na parada também a TDI, FRANCESA, DIGITAL IMAGES, com T.D. EXPLORE que foi o softer que a gente acabou comprando mais tarde. Aí, o Serginho foi lá e tentou negociar uma estação pra trazer WAVEFRONT, mas os caras resolveram que eles não vendiam estação SILICONGRAFIC pro Brasil, porque os militares na época tinham um Projeto para fazer bomba atômica aqui, e uma máquina dessas poderia ser usada para desenvolver máquinas nucleares.

ML - um americano falou para o Serginho e foi taxativo nesse sentido?

AB - Foi. E o Governo americano disse que não autorizaria a venda de um sistema desses para o Brasil e tal, foi meio complicado e também era mais caro, e eu não lembro quanto era na ocasião. E por varias coisas que o Serginho viu ali, ele decidiu que o sistema novo da CUBICOMP era um sistema bem razoável e a fita que ele viu de demonstração, era, tinha o que a gente precisava para executar o trabalho. Ele trouxe a fita para cá e a gente foi visitar um CUBICOMP PICTURE MAKER 3, que tinha no RJ, do Ormeu, e a gente foi ver como que era, e se tinha sombra, imagina o que era vendido como benefício! Ele conseguia fazer sombra softer; reflexo já tinha e fazia algum tempo, e era uma coisa caríssima o reflexo; transparência com reflexo, com... BANDNIP, par de relevo. 55.52. Ok, e tava dentro, uns 30 e poucos mil dólares, 30 ! Não, acho que era 60 mil dólares, e a gente conseguiu comprar e instalar lá e ficamos 02 meses fazendo o job. Mandamos para os caras do job, as $1^{\text {a }}$ fotos, e ficaram alucinados com a qualidade; mas quando eles viram o trabalho pronto, eles ficaram decepcionados porque era muito rápido; e a gente tinha avisado que o tempo daquele negocio era muito lento e tal. Veja o atrevimento nosso, a gente não tinha PREVIEW da animação. O preview do cubicomp era feito não era feito com $56.45 \mathrm{com}$ um frame normal, ele era um wire.FRAME feito numa tela, ele ia imprimindo uma imagem em cima da outra, e depois ele fazia ...ciclava um frame preto por todas as imagens que estavam impressas ali, era uma única tela e fazia o que se chama de COLOUR MAP, pegava cada frame e pintava de preto ali. Como você tinha feito um frame em cima do outro, e conforme a animação fosse ficando mais lenta, ela ia sumindo, porque um ia aparecendo em cima da outra, e aí aparecia só a ultima. Então eu fazia animação e tinha que ficar assistindo horas, horas tentando ver se tinha algum defeito, algum problema. Não tinha nenhum preview colorido.

ML - animação, era praticamente quadro a quadro ou você conseguia determinar Key frame...

AB - Por Key- frame.

ML - tinha assim, uma time line...

AB - Tinha. E tinha até, uma coisa que era novidade e fundamental e eu apanhei muito nisso no $1^{\circ}$ cubicomp que eu brinquei na GLOBOTEC, mas assim, a gente não conseguia visualizar que as curvas de easy-in, tinha gráficos de animação. 57.30

ML - ia ralentando num dato momento? Você tava trabalhando easy in 58.00

$A B$ - Exatamente, tinha curva de easy in, você visualizava essa curva. $E$ eu consegui aprender intuitivamente, para que servia aquilo? E eu consegui intuir, se a curva fizesse SMOOTH 58.09, o movimento daria SMOOTH, e se a curva estivesse quebrada, o 
movimento estaria quebrado, e nisso a gente tinha uma grande vantagem sobre o pessoal que trabalhava aqui, porque as pessoas não se ligavam nisso. O movimento de câmera era tudo: TUM TUM TUM, aquela coisa super grotesca. E quando o diretor chegou aqui, os movimentos era suaves, aquela coisa cinematográfica. Eu vinha com uma cultura de star Wars, de cinema, de cultivar efeitos especiais, de estudar fotografia e cinematografia, então a gente aplicava isso nos nossos trabalhos e a gente tinha um diferencial grande por conta disso. A gente tinha um discurso artístico, tínhamos um discurso cinematográfico, mas isso foi mais pra frente. E a gente fez esse trabalho ao longo de 2 meses e eu fui ver o trabalho pronto no ultimo dia, quando a gente foi em uma produtora contratada, pra pegar o que a gente conseguiu gravar em disco, uma mídia magnética... 58.58, super estranha que a gente descobriu ali. Gravamos lá 40 gigabytes, 40 megabytes, não lembro mais, acho que 40 megabytes de arquivo, pra passar para a fita e só depois que passou para a fita foi que vimos a animação pronta e tava boa. E a gente festejou "conseguimos", nós ficamos o dia inteiro para gravar. O dono da produtora chamou a gente e falou "escuta, eu preciso de mais dinheiro, vocês falaram que iam ficar aqui 4 horas, e vocês estão há 6 horas aqui", e a gente não tinha dinheiro, e eu estava até pensando em pegar minhas economias... "a gente não tem mais dinheiro, mas a gente vai voltar aqui para fazer mais trabalhos", e foi aí que vimos a animação. $E$ aí teve uma longa história porque a gente teve que fazer de novo porque eles não aprovaram, e foi a coisa mais deprimente da minha vida, quando o cliente não aprovou o filme, e a gente tava lá sem dinheiro, e com o visto estourado e não tinha mais o que fazer, foi um momento de terror. $E$ depois a gente descobriu que ele queria outra animação, não foi que ele não gostou, porque ele tinha adorado, e ele queria mais tempo... Isso foi um dia depois, a gente tava quase se matando lá, eu e o Serginho, e a gente foi até comer uma refeição, a gente comia no KFC, uma refeição por dia e todo dia, isso para economizar, me a gente andava $2 \mathrm{~km}$ para ir até o KFC e voltar. E nesse dia a gente foi no Wendy's, que era mais caro, pouco mais caro e comemos um bife com sobremesa e tal, só para tentar levantar o espírito e na volta, o nosso colega, amigo e funcionário: "não é bem isso, o cara adorou", e o diretor do filme tinha passado uma coisa pra gente, totalmente negra, reprovação.

ML - vocês estavam fazendo o trabalho lá, e como mostraram para o cliente aqui?

AB - A gente mandou a fita, via correio, a gente tinha várias cópias. A gente conseguiu fazer de novo o trabalho e mais longo do que o cliente queria, e ele pagou por isso. E a gente chegou aqui e já começamos a produzir, e a gente passou a ser o rival do José Dias e numa categoria inferior.

Bom, foi daí pra frente que a gente foi entrando no 3D acabamos comprando uma Sillicon GRAPHICS para ascender ao mercado HIGHT END, porque o Hi-end era o que trabalhava com Sillicon Graphics, que era um mercado; e o LOW END trabalhava com PC.

$M L$ - você acha que isso foi o $1^{\circ}$ salto?

AB - Foi o $1^{\circ}$ salto. A gente teve uma associação com o pessoal da Jovem Pan.

ML - e o Amiga?

AB - Amiga continuou funcionando por um tempo, fazendo animação 2D, depois acabamos abandonando.

ML - quanto custava uma SILLICON?

AB - A Silicon que a gente colocou a mão, custava 75 mil dólares, uma 4D-25

ML - sem software? 
AB - Não, acho que o sistema todo, incluindo o T.D.I Explore. Eu te falei que o Cubicomp tinha custado 60, preciso conferir, acho que era, porque quando a gente levava o sistema de um andar para o outro, em cima de um carrinho, a gente falava assim "sai da frente que vai passar um porshe", "sai da frente que vai passar um Apartamento" custava o preço de um Apartamento.

ML - vocês tinham uma restrição a quem fosse tocar, porque era uma coisa muito cara, delicada. Ou você já começou a contratar estagiário, ou as pessoas que trabalhavam junto, você deixava que tocasse...

Acho também um tema legal, Pelo menos num dado momento, o Guto falou que eram chamados a colaborar e propor soluções e as agencias falavam ok. Hoje com todos esses recursos, filmes do mundo inteiro ali e você vê no seu teclado... Eles já chegam com a coisa pronta, "é isso que a gente quer?"

AB - Não. Eles não sabem hoje em dia o que eles querem.

ML - depois eu gostaria que você falasse quem define, acho que eu sei a resposta, quem define o layout artístico, naquela época e hoje? Decupagem, story-board, animatic... Eu tinha te cortado, eu tinha te perguntado se tinha uma questão de quem pode mexer na máquina e quem não pode? Como eu era o único cara estudado no cubicomp, eu era o cara, vamos dizer assim, eu tinha o privilegio de pegar a máquina mais forte.

ML - O Serginho trabalhava também?

AB - Ele tentou uma época trabalhar e ele não se deu bem, não gostou, não curtiu. Ele até tentou fazer, mas ele virou o cara Administrativo, mais que isso, o empreendedor, o cara que tinha a visão, mas ele sabe e conhece todo o processo. Ele só não senta para fazer, ele é capaz de discutir com você, de qual maneira e de qual modo fazer e resolver, ele conhece os procedimentos, uma cara super interessado, ele domina o assunto. Às vezes eu até consulto ele: "o que você acha disso daqui?"; mas hoje a gente tem um monte de gente aqui; mas na época, quando eu tinha o $1^{\circ}$ Amiga, a gente contratou... aí o Guilherme veio trabalhar com a gente, nosso amigo; quando chegou o $2^{\circ}$ Amiga, um Amiga um pouco mais rápido e que tinha $\mathrm{HD}$ e tal, eu fiquei com o Amiga mais novo e ele ficou com o Amiga menor. Quando chegou o CUBICOMP ele ficou trabalhando no Amiga; quando chegou SILICON, eu passei para SILICON e ele ficou com CUBICOMP, depois ele também começou a trabalhar com a SILICON; aí entrou o Alê, nos anos $90 \ldots$

ML - conheci...

AB - E aí foi entrando, a gente foi para a Jovem Pan, tivemos contato com o pessoal da Jovem Pan; aí o Marcos que trabalhava na Jovem Pan, ele passou a trabalhar com a gente também; e a gente saiu, e a gente montou aqui na Pedroso; aí passamos de uma 4D-25 para uma 4D-35, mas era ainda uma SILICON única.

AB - No começo a gente disputava mercado com A GLOBOGRAph, era empresa do Dias que fazia trabalho aqui para comerciais; e com a GLOBOTEC, e mais algumas empresas; mas a gente teve logo de cara uma boa penetração no mercado, porque o trabalho tinha um diferencial legal, diferencial bacana. Nosso discurso era artístico, discurso de cinematografia, enquanto que a Globo chegava com discurso de tecnologia. A maior parte das empresas vendia tecnologia, "venham fazer $3 \mathrm{D}$ conosco porque nós temos a mesma máquina que fez o filme NÃO SEI O Que LÁ", "Nós trabalhamos com SILICON GRAFIC, a tecnologia mais avançada e a disposição do seu filme". E a gente vendia o discurso ao contrário, porque a nossa máquina não era melhor, a gente ... Mas mesmo assim, se você não tivesse uma SILICON você ficara restrito pra determinados trabalhos. Bom, a gente começou a disputar 
mercado com o Dias, só que claro que ele levava grande vantagem de ter a estação gráfica superior e ter o nome da Globo e ter o trabalho do Hans Donner, um trabalho bom; mas para nossa felicidade a Globo resolveu fechar a GLOBOGRAph, acharam que não era uma boa ideia, não era bom negocio e tirou ela do mercado, então a gente conseguiu avançar daí pra frente.

$\mathrm{Na}$ época da Jovem Pan entrou, chamou para ser sócio o Alberto que era amigo de infância do Serginho e que tinha uma produtora de vídeo e ele era um cara ótimo de vender o trabalho, ele não era um vendedor, ele era um Relações Públicas, um atendimento e ele tinha muito contato nas agências, ele inclusive já tinha arrumado muito trabalho pra gente, enquanto a gente estava aqui na Tabapuã com a VIDEOLAR...

Esqueci de contar, num dado momento o Toni cansou, a gente na verdade não estava fazendo rios de dinheiro, mas ele gostava muito da gente e ele nos fez assim, a delicadeza de propor, de vender a empresa de volta para gente e pelo mesmo preço que a gente pagou, e sem nenhum ágio. $\mathrm{E}$ a gente com a empresa dele...

ML - era época da inflação...

AB - Sim, do plano cruzado, plano Collor. Mas tudo foi em dólar. Depois do plano Collor eu lembro que eu só consegui comer, depois que o Alberto, ele ainda não era nosso sócio, mas ele trouxe um job para fazer lá do Curso MED e tal.

ML - qual foi o impacto do plano Collor?

AB - É que não tinha mais trabalho. A gente não tinha dinheiro no Banco, a gente não tinha conseguido ganhar dinheiro suficiente para ter uma reserva no Banco ou par ter um caixa grande, nosso caixa era pequeno; então a gente sofreu pouco, assim, a gente não perdeu uma grande quantidade de dinheiro; a gente tinha coisas para receber.

ML - tinham funcionários contratados?

AB - Tinha.

ML - quantos funcionários contratados? Quando você adquiriu o $1^{\circ}$ SILICON você se lembra...

AB - Não. Isso não foi no Plano Collor, isso foi antes.

ML - O SILICON é de qual época?

AB - Eu tenho uma grande dificuldade de localizar lá no tempo. O plano Collor foi em 86 ..................final da $1^{\mathrm{a}}$ parte do áudio.

ML - A gente estava falando quando você ocupou o espaço ocupado pela GLOBOTEC...

AB - GLOBOGRAPH.

ML - e aí você tava falando do plano Collor, que aí vocês conseguiram um job, e foi a partir daí...

AB - O Alberto conseguiu trazer para a gente um job do Cursinho MED, que tinha uma pastinha falando: "ola, eu sou a pastinha do curso MED", se a minha memória não me trai, foi o job que salvou a nossa vida naquele mês, fatídico de janeiro do plano Collor; e dai começou a pingar jobizinho daqui e dali e a gente conseguiu viver, mas sofremos antes 0 baque como todo mundo é claro. A gente conseguiu sobreviver com base no que ia entrando ali. E o calote foi generalizado; você não pagava aluguel e o cara não tinha nem 
como te cobrar aluguel: "como eu vou te pagar aluguel se eu não recebo!" houve então um adiamento generalizado de pagamentos e aos poucos a coisa foi de ajeitando, mas eu lembro que foi traumático. Depois pela próprio influência do Alberto a gente entrou em contato com o pessoal da PAN, queriam montar uma televisão aqui, mas eu prefiro não prefiro entrar nessa historia da TV JOVEM PAN; em contato com o Pessoal da PAN, fomos trabalhar lá dentro e a gente conseguiu a $1^{\text {a }}$ SILLICON e foi nos associando com o pessoal da JOVEM PAN. Depois a gente saiu, e depois conseguimos comprar uma outra SILIICOM, e aí foi crescendo, e aí pelas próprias pernas a VETOR foi investindo, até que num dado momento, aí a LOBO, o pessoal da LOBO veio nos procurar, e Nando o Mateus falou assim: "ao invés da gente brigar no futuro, vamos nos associar para tentar fazer um negocio legal e tal" e aí foi muito bom porque lá eles tinham um trabalho muito mais voltado para criação, era um trabalho mais moderno e mais de vanguarda do que eu fazia, isso porque o meu trabalho é muito mais efeito especial do que propriamente animação, então servia para algumas coisas e não tão bem para outras. Então estava havendo uma mudança na qualidade do visual que era esperado do 3D, da animação computadorizada, e eles vieram e entraram com trabalho de animação tradicional, com STOP MOTION e com coisas que eles já faziam fora o 3D e também com 3D; então a gente montou uma empresa associada, funcionando em dois andares diferentes e a gente passou a fazer pós produção, compramos um FLAME 03.51, e passamos a fazer a parte de COMP e aí fomos crescendo e crescendo.

$M L$ - quando foi o $1^{\circ}$ filme que você fez e que você lembra de junção com filme ao vivo?

AB - Tem um filme que foi importante pra gente nessa direção, por que teve um fenômeno curioso com a recepção do 3D, animação computadorizada aqui no Brasil. no $1^{\circ}$ momento todo mundo queria porque era sinônimo de alta tecnologia, então você tinha que às vezes trabalhar em baixa resolução para que as pessoas percebessem que era resolução gráfica, pra que não deixasse duvidas que era computação gráfica. $E$ todo mundo queria e passou a querer na época, o que a gente chama de FLYING LOGO, logotipo voador para fazer assinatura, metálico, de vidro, etc., e a gente conseguia fazer uns logotipos VOADORES bem bacana, melhores que os da concorrência, e as pessoas ficavam felizes com isso. $E$ o sonho de todos nós era animar personagem, animar espaçonave, coisas que ainda não dava para fazer na época, o 3D não tinha chegado numa capacidade de realismo que pudesse, e a gente via gente lá fora fazendo personagem, mesmo que não fosse foto realista, mas era bacana, legal, coisas divertidas e interessantes. $E$ aí nesse $1^{\circ}$ momento de aceitação cega, passou haver uma rejeição dizendo que a computação gráfica era fria, feita por computador, era brega, era metálica, era não sei o que... Eu lembro que a gente foi chamado de novo para fazer uma abertura do Vídeo Brasil e o diretor de arte que veio falar com a gente, ele veio com a conversa: "eu não gosto muito de computação gráfica, acho meio brega e tal. E eu: "e o que você veio fazer aqui?". Ele: "não é a $1^{\text {a }}$ coisa que eu quis fazer, vou fazer uma animação de frutas", isso pera uma coisa que o Peter Gabriel tinha feito, e eles queriam fazer aquilo, porque aquilo era quente, humano, não digital e portanto: bacana. Então a gente teve uma fase de rejeição e a gente ficou fazendo um trabalho meio secundário; mas nessa época a gente começou a trabalhar com Wellington Amaral que era um dos grandes diretores de filme de publicidade na época, era o bam-bam-bam, dono da 5.6 e ele acreditou muito no trabalho e no talento da gente. $E$ o $1^{\circ}$ filme que a gente combinou animação 3D ao vivo, foi um filme para o Banco do Brasil dou Caixa Econômica, um filme de banco, onde a ideia era assim "o seu dinheiro fica dormindo e a gente trabalho para você, você pode dormir tranquilo", e ele tinha sido concebido para ser uma nota de dinheiro num cenário super fofinho, meio Disney, de cama e com iluminação, bem fantasiosa e a nota dormindo e respirando, virando de lado e tal... E a agencia não sabia como fazer isso, então o Wellington, falou: "vamos fazer em computação gráfica",

e os caras: "não, nem fodendo, é frio, brega, metálico".

E ele: "não, eu conheço os caras que fazem legal".

E os caras: "não Wellington, pelo amor de Deus, não vamos fazer, não com computação gráfica, vamos fazer com uma nota de borracha, com fio" 
E ele: "esquece, o único jeito de fazer esse filme é com computação gráfica".

E os caras: "você banca e afirma que vai ficar bom?"

Ele:"afirmo", e ele confiou no nosso trabalho e foi nosso $2^{\circ}$ padrinho. Nosso $1^{\circ}$ padrinho foi o Cauby. E aí a gente fez o trabalho, a agência adorou e foi um puta sucesso.

ML - E o ano você não lembra? Você tem esse filme?

AB - Sim.

ML - Eu peço por email uma listinha de algumas coisas. E tem a questão da textura, vocês se ligaram num dado momento, que a coisa toda ia progredir quando vocês investissem em textura...

AB - Sim, exatamente.

ML - no começo você falou que fazia lisinho para o pessoal se ligar que era moderno e novo. Depois começou a ter rejeição. E aí vocês já estavam numas de estudar uma coisa mais organiza.

AB - Sim, a gente tentava fazer, mas o sistema era muito limitado. Mesmo a nossa $1^{\text {a }}$ SILICON, a gente só conseguia, o $1^{\circ}$ softer que a gente tinha, a gente tinha que escolher se a gente usava no mesmo objeto COLOR MAP ou BUMP MAP, ou mapa de cor ou mapa de relevo, não dava para juntar os dois e só... Não vou entrar em detalhes técnicos, mas a gente tinha que escolher. A gente teve a sorte de fazer para o pessoal da SUPER INTERESSANTE, da Abril, fazer direto um filme de 30 segundos, todo em 3D, isso era meio o nosso sonho, e os caras deixaram a gente criar. Eu te mostro.

ML - Carta Branca...

AB - Carta Branca.

ML - você tinha tido uma experiência dessas antes?

AB - Não. A gente apresentou a ideia, o cara comprou e a gente fez e foi para o ar daquele jeito e foi lindo.

\section{ML - filme da SUPER INTERESSANTE?}

AB - Isso. eu coloquei ali tudo que eu gostava, quadro de magritte 09.39, a capa da super é o quadro de magrite. A gente colocou uma baleia debaixo dágua, a gente colocou um astronauta em 3D e foi a $1^{\text {a }}$ figura humana feita no Brasil. veja, para essa figura humana, no sistema ele não aceitava auto shedol, um objetivo projetava a sombra no outro, mas o mesmo objetivo não projetava a sombra em sim mesmo, então o nariz do astronauta não projetava a sombra no rosto, e para fazer as narinas não ficarem brancas, eu tive que usar duas luzinhas negativas dentro do nariz, coisa que só é possível em computador, luz negativa. Era uma luz que projetava escuro, dentro da narina para que não ficasse branco. Muitas figuras humanas rudimentares da época, tinham as narinas brancas, e as pessoas não se ligavam que era um defeito inaceitável; mas a gente conseguiu fazer e o astronauta foi um sucesso no Brasil. a empresa que fabricava o softer, pediu o astronauta para botar na SIGRIFIS 10.39 e fizeram uma imagem gigante do astronauta e infelizmente eu não pude ir naquele ano, curtir a minha gloria naquele momento. Eu não tinha nada no Brasil, aparecendo lá fora. Então a gente conseguia fazer essas coisas e aí o pessoal começou a se ligar que dava para fazer algumas coisas em 3D, e muitas vezes chamavam a gente e consultavam a gente pra fazer o Projeto e ver se era legal ou não. A gente conquistou um nome de respeito, a ponto de nos consultar. $E$ aí chegou num ponto no Brasil que chegou $o$ 
Jurassic Park e o Terminator 2, e aí foi uma resolução, e aí o pessoal falou "opa, pera ai, dá pra fazer alguma coisa". e aí a confiança dos clientes foi crescendo, mas muita gente ainda falava assim: "não, não dá, vai ficar parecendo 3D"; A gente via muita animação feita no ar com boneco e que parecia o 3D. A gente tava no limite do que parecia uma coisa e outra, e essa situação persiste até hoje. Muitos clientes nossos detonam cenas filmadas, achando que não ta realista o suficiente e pesando que tem efeito, e não tem, é um filme, e o cara rejeita, isso porque o 3D ta tão perfeito que o pessoal agora acha que tudo é 3D, então a gente tem dificuldade. Toda vez que você quer trazer realismo para a estória, você esbarra em certas coisas: "não ta perfeito, tem um risquinho aqui e eu não quero", mas o risquinho é o movimento da pele.

ML - Por que se tiver mais perfeito do que isso...

AB - Vai ficar mais desumano...

ML - como é o nome desse efeito?

AB - UNCANNY VALLEY. Eu não sou tão adepto a essa teoria do uncanny valley, eu não acho que, por exemplo, essa menina que a gente tava fazendo aqui agora 3D, ela é próxima de um ser humano e não é um ser humano, mas eu não acho que ela é desagradável CREEP, as pessoas querem dizer que fica CREEPE. Alguns trabalhos sim...

ML - qual a dica que você dá visualmente para dizer que ela não é humana?.

AB - Não trabalhou pra ser $100 \%$, e isso é um trabalho quase que insano, impossível. Você vê, precisa de um estúdio inteiro, durante 02 anos pra fazer o Benjamin Button e era só a cabeça dele, e mesmo assim eles digitalizaram tudo. Fazer uma figura humana mesmo, a gente não pegaria. O ideal é que ela não pareça 100\% humana, senão, não tem Graça. Tem que ser quase humana e levemente estilizada, mas tem que ter Graça, tem que ser warm não pode ser fria. E a gente tá trabalhando aqui nesse sentido.

ML - muito obrigada. 


\section{Referências Bibliográficas}

ALCÂNTARA, E. A rede que abraça todo o planeta. Veja. São Paulo, 1 mar. 1995. Seção Arquivo Veja. Disponível em: <veja.abril.com.br/arquivo_veja/capa_01031995.shtml> Acessado em: 04/03/2014

ALtMAn, R. Sound Theory, Sound Practice. New York: The American Film Institute, 1992.

ARIKAWA, M. A evolução da animação brasileira em peças publicitárias. $2005.127 \mathrm{f}$. Dissertação (Especialização em Comunicação Audiovisual) - Setor Ciências Jurídicas e Sociais, Pontifícia Universidade Católica do Paraná, Curitiba, 2005.

Disponível A evolução da animação. Observatório da imprensa. 14 Maio. 2013. $<$ http://www.observatoriodaimprensa.com.br/news/view/ ed746 a evolucao da animacao $>$ Acessado em: 26/11/13.

ARNHEIM, R. Arte e Percepção Visual: uma psicologia da visão criadora. São Paulo: Pioneira Thomson Learning, 2005.

AUMONT, J. A Imagem. Campinas, SP: Papirus Editora, 2004.

BARBOSA, A.L.P. A relação som-imagem nos filmes de animação norte-americanos no final da década de 1920: do silencioso ao sonoro. 2009. 119 f. Dissertação (Mestrado em Ciências da Comunicação) - Escola de Comunicação e Artes, Universidade de São Paulo, São Paulo, 2009.

BENDAZZI, G. Cartoons: One Hundred Years of Cinema Animation. London: John Libbey \& Co. Ltd, 1994.

BORDWELL, D.; THOMPSON, K. Fundamental Aesthetics of Sound in the Cinema. In: WEIS, E.; BELTON, J. Film Sound: Theory and Practice. New York: Columbia University Press, 1985. p. 181-199.

BRASILANIMA. Desenvolvido por Quiá Rodrigues. Disponível em: $<$ brasilanima.blogspot.com.br>. Acessado em: 23/04/2012

CHONG, A. Basics Animation 02: Digital Animation. [New York]: Ava Publishing, 2011. 2 vol.

COLEÇÕES computadores e internet. Arquivo Veja. Disponível em: $<$ veja.abril.com.br/arquivo_veja/computadores-internet-reserva-mercado-pc-web-sitesbolha.shtml> Acessado em: 06/06/2013

CRAFTON, D. Before Mickey: The Animated Film 1898-1928. Chicago: University of Chicago Press, 1993. 
DARLEY, A. Second-order Realism and Post Modernist Aesthetics in Computer Animation. In: PILling, J. A Reader in Animation Studies. [S.I.]: Indiana Univertity Press, 1997. p. $16-24$.

DENSLOW, P.K. What is animation and who needs to know? An essay on definiitions. In: PILLING, J. A Reader in Animation Studies. [S.I.]: Indiana Univertity Press, 1997. p. 1-4.

EIKHOF, D.R.; HAUNSCHILD, A. For art's sake! Artistic and economic logics in creative production. Journal of Organizational Behavior, [S.I.], v. 28, n. 5, p. 523-538, 2007.

BRUZZO, C.; FALCÃO, A. R. et al. (Coord.). Coletânea Lições com Cinema. São Paulo: FDE, Diretoria de Projetos Especiais/ Diretoria Técnica, 1996. 4 vol.

FIALHO, A. Desvendando a metodologia da animação clássica: A arte do desenho animado como empreendimento industrial. 2005. 201 f. Dissertação (Mestrado em Artes) Escola de Belas Artes, Universidade Federal de Minas Gerais, Belo Horizonte, 2005.

FILME Cultura. Rio de Janeiro: Secretaria do Audiovisual, Ministério da Cultura, edição 05, jul./ago. 1967. Disponível em: <www.ctav-sav.com.br>. Acessado em: 20/07/2013

FILME Cultura. Rio de Janeiro: Secretaria do Audiovisual, Ministério da Cultura, edição 18, jan./fev. 1971. Disponível em: <www.ctav-sav.com.br>. Acessado em: 20/07/2013

FILME Cultura. Rio de Janeiro: Secretaria do Audiovisual, Ministério da Cultura, edição 49, 2007. Edição Especial. Disponível em: <www.ctav-sav.com.br>. Acessado em: 02/12/13.

FILME Cultura. Rio de Janeiro: Secretaria do Audiovisual, Ministério da Cultura, edição 60, jul./ago./set. 2013. Disponível em: <www.ctav-sav.com.br>. Acessado em: 25/08/2013

GARNICA, A.V.M. História Oral e Educação Matemática. In: BORBA, M.C;. ARAÚJO, J.L. (Org.) Pesquisa Qualitativa em Educação Matemática. Belo Horizonte: Autêntica, 2004. cap., p. 77-98.

GRAÇA, M. E. Entre o olhar e o gesto: elementos para uma poética da imagem animada. São Paulo: Senac São Paulo, 2006.

GRAPHICINEMA. Desenvolvido por Fernando Ferreira Garróz. Disponível em: <graphicinema.blogspot.com.br> Acessado em: 06/06/2014

INFOPÉDIA. Silicon Graphics. Disponível em: <infopedia.pt/\$silicongraphics;jsessionid $=$ vCD01DRqTozzS0JDWSmLtg

leoribeiroanima.blogspot.com.br> Acessado em: 06/06/2014

JOHNSTON, O.; THOMAS, F. The illusion of life: Disney animation. New York: Hyperion, 1995.

JÚNIOR, A.L. Arte da animação. São Paulo: Senac São Paulo, 2005.

MACHADO, A. Pré-Cinemas \& Pós Cinemas. Campinas, SP: Papirus Editora, 1997. 
MACHADO, M.C. Gestão de pessoas em estúdios de animação: entendendo as pequenas empresas da indústria criativa brasileira. 2012. 199 f. Dissertação (Mestrado em Administração de Recursos Humanos) - Faculdade de Economia, Administração e Contabilidade, Universidade de São Paulo, São Paulo, 2012.

MAGAlHÃES, M. Novos Caminhos para a Animação Experimental. Revista Filme e Cultura. Rio de Janeiro, $\mathrm{n}^{\mathrm{o}}$ 54, p. 46-48. maio. 2011. Disponível em: <www.ctavsav.com.br>. Acessado em: 06/06/2014

MALTIN, L. Of Mice and Magic: a History of American Animated Cartoons (Revised and Updated Edition). New York: Penguim Books, 1987.

MARCONDES FILHO, C. Televisão: a vida pelo vídeo. São Paulo: Moderna, 1991.

MEIHY, J.C.S.B., Manual de História Oral. 4 ed. São Paulo: Loyola, 2002.

MORENO, A. A Experiência Brasileira no Cinema de Animação. Rio de Janeiro: Editora Artenova, 1978.

MOURA, R. A Bela Época (Primórdios-1912). In: RAMOS, F. (Org.). História do Cinema Brasileiro. 2 ed. São Paulo: Art Editora Ltda., 1987. cap. 1, p. 9-62.

NESTERIUK, S. Dramaturgia de série de animação. São Paulo: Sérgio Nesteriuk, 2011.

PANDOLFI, F.L. Movimento e emoção: uma reflexão sobre a arte da animação e seu aprendizado no Brasil. 2011. Trabalho de Conclusão de Curso (Comunicação Social) Faculdade de Meios de Comunicação Social, Pontifícia Universidade Católica do Rio Grande do Sul, Porto Alegre, 2011.

PURVES, Barry. Animação Básica 04: Stop-motion. Vol. 4. Porto Alegre: Bookman, 2011.

RAMOS, F.; MOURA, R. História do cinema brasileiro. São Paulo: Art Editora, 1987.

RICHARDSON, R.J. Pesquisa Social: métodos e técnicas. São Paulo: Atlas, 1999.

SILVA, R.F. De um pioneiro a outro, um salto da tecnologia no cinema de animação brasileiro. 1999. 120 fls. Dissertação (Mestrado em Ciência da Comunicação) - Escola de Comunicações e Artes, Universidade de São Paulo, São Paulo, 1999.

SMITH, A.R. Microsoft Corporation. Digital Paint Systems: Historical Overview. [S.I.], 1997, $11 \mathrm{p}$.

WIKIPÉDIA. Timeline of computer animation in film and television. Disponível em: $<$ en.wikipedia.org/wiki/Timeline_of_computer_animation_in_film_and_television>. Acessado em: 06/06/2014

WILLIAMS, R. The Animator's Survival Kit. London: Faber and Faber, 2001. 